\author{
UNIVERSIDADE DE SÃO PAULO \\ Instituto de Física \\ Instituto de Química \\ Instituto de Biociências \\ Faculdade de Educação
}

MARCÍLIA ELIS BARCELLOS

\title{
CONHECIMENTO FísICO E CURRÍCULO: \\ PROBLEMATIZANDO A LICENCIATURA EM FÍSICA
}

São Paulo

2013 



\section{MARCÍLIA ELIS BARCELLOS}

\section{ConHeCIMENTO físico e CURRículo: \\ PROBLEMATIZANDO A LICENCIATURA EM FÍSICA}

Tese apresentada ao Programa de PósGraduação Interunidades em Ensino de

Ciências como requisito parcial para a obtenção do título de Doutor em Ensino de Ciências.

Área de concentração: Ensino de Física

Orientadora: Prof ${ }^{-}$Dra. Maria Regina Dubeux Kawamura

São Paulo 2013 
Autorizo a reprodução e divulgação total ou parcial deste trabalho, por qualquer meio convencional ou eletrônico, para fins de estudo e pesquisa, desde que citada a fonte.

FICHA CATALOGRÁFICA

Preparada pelo Serviço de Biblioteca e Informação do Instituto de Física da Universidade de São Paulo

Barcellos, Marcília Elis

Conhecimento e currículo: problematizando a licenciatura em física.-São Paulo, 2013.

Tese(Doutorado) - Universidade de São Paulo.

Faculdade de Educação, Instituto de Física, Instituto de

Química e Instituto de Biociências

Orientador: Profa. Dra. Maria Regina D. Kawamura

Área de Concentração: Ensino de Física

Unitermos: 1. Física (Estudo e ensino); 2. Formação de professores; 3.Currículos e programas; 4. Licenciatura.

USP/IF/SBI-094/2012 


\section{A meu pai}





\section{AGRADECIMENTOS}

Agradeço imensamente aos espaços e tempos que me permitiram dialogar com o mundo por meio desse trabalho. Agradeço a tudo e todos desse imponderável espaço tempo curvo, torto e indefinido.

Meu mais que sincero e emocionado obrigada à prof ${ }^{a}$ Maria Regina Kawamura por não ter permitido que eu entrasse na inércia de parar, por me fazer crescer mesmo quando "doíam os ossos" e principalmente pela paciência e insistência para que eu aprenda a me proteger das minhas certezas.

Ao querido professor João Zanetic eu agradeço imensamente por me ajudar a construir os referenciais políticos e os valores sobre os quais eu exerço a minha existência como professora, como pesquisadora e como ser humano.

Embora coubessem aqui mais algumas páginas de agradecimentos citando pessoas importantes a esse trabalho e a minha vida, vou optar por não "marcar os pontos" de forma precisa, e sim, apenas delimitar espaços e tempos. Mas farei isso entendendo que os lugares e épocas só fazem sentido pelas pessoas que encontramos no caminho. Esse caminho que a gente faz só caminhando e apenas enquanto se caminha...

Muito obrigada ao espaço tempo da cidade de Curitiba, da infância e juventude, que permitiu o começar dessa caminhada desde o lar maravilhoso no qual surgiu essa curva, a minha curva, até os caminhos da UFPR, que me encaminharam para novos, mais incríveis e inusitados caminhos.

Muito obrigada ao espaço tempo da cidade de São Paulo que fez caber o mundo inteiro em poucos espaços singulares e densos, que explodiram em pares de vários eu(s) diferentes, contraditórios, complementares. Como sempre, em algum momento, há uma quebra de simetria. Acho que uma parte mais madura do meu eu escapou para outro espaço tempo...

Muito obrigada ao espaço tempo do lar, do meu lar, do lar que eu tenho hoje e que é o ponto mais especial do mundo! 
Muito obrigada ao Rio de Janeiro e tudo desse espaço-tempo, lindo, bem humorado, leve e que hoje faz parte dos pontos da minha curva e que, portanto, define também os novos caminhares do meu caminho.

Muito obrigada a "Casa da Sogra", meu pedacinho de São Paulo, talvez o mais denso e singular de todos, que ajudou meu caminho a continuar caminhando nesse caminho, que só é caminho, quando se levanta e se caminha de novo.

Muito obrigada à cidade de Petrópolis e aos caminhos que eu encontrei por aqui entre o verde da montanha e o azul do céu, no qual se encontra o ponto do meu lar, meu prumo, e todas as condições de contorno que me permitirão continuar esse caminhar, que se faz, e ao mesmo tempo me faz.

Muito obrigada a tudo e todos que fizeram parte do meu caminho, e a tudo e todos que se farão e me farão como um pedacinho desse meu caminho! 
Preciso ser um outro para ser eu mesmo

Sou grão de rocha Sou o vento que a desgasta Sou pólen sem insecto Sou areia sustentando o sexo das árvores Existo onde me desconheço aguardando pelo meu passado ansiando a esperança do futuro No mundo que combato morro no mundo por que luto nasço Mia Couto 



\section{RESUMO}

BARCELLOS. M. E. Conhecimento físico e currículo: problematizando a licenciatura em física. 2013. 257f. Tese (doutorado) - Universidade de São Paulo, São Paulo, 2013.

A formação de professores está presente entre as questões mais atuais da pesquisa em educação e em muitos dos discursos que balizam as políticas públicas. Documentos oficiais, como as diretrizes para a formação de professores da Educação Básica, de 2002, sinalizam necessidades de mudanças na formação inicial, especialmente no que diz respeito à superação de fragmentações. Isso significa, no caso específico da física, que, por exemplo, a formação inicial não pode se reduzir à superposição do aprender física com o aprender a ser professor. Diante desse quadro, buscamos investigar qual é o papel dos saberes de física na formação do professor, que espaços e formas esse saber ocupa nos currículos dos cursos de licenciatura e quais relações se estabelecem entre esses e os outros saberes presentes na formação inicial. Para isso, utilizamos referenciais teóricos da área de formação de professores e de teorias de currículo. Delimitamos três âmbitos de investigação, ainda que interdependentes: (i) políticas públicas gerais, (ii) resultados de pesquisas em ensino de ciências, expressão da comunidade de pesquisa da área, além dos (iii) espaços de concretização das práticas, referente aos cursos de licenciatura propriamente ditos. Para tanto, pesquisamos documentos oficiais e obras de cunho histórico sobre a formação de professores e a escola básica no Brasil; analisamos artigos presentes nas atas de eventos da área de ensino de ciências; investigamos cursos de licenciatura e mudanças curriculares, com atenção especial ao estudo em caso de um curso específico de licenciatura em física. Em todos esses momentos, procuramos caracterizar quais saberes específicos de física e quais saberes pedagógicos estavam sendo considerados, além de qual articulação entre esses saberes estava sendo proposta. $\mathrm{Na}$ maior parte do material analisado, constatamos que os saberes de física estão fortemente naturalizados. Isso significa que, a despeito das sinalizações de mudanças mais recentes, os saberes de física presentes nos cursos de licenciatura não têm sido alvo de questionamentos, problematizações ou propostas expressivas de modificações. São considerados como decorrentes de certa lógica interna da ciência, já instaurada nos cursos superiores de física. Nossos resultados sinalizam que sem tais reflexões, em que as questões das finalidades formativas ganhem destaque, será muito difícil superar a dicotomia entre saberes. No entanto, no caso específico analisado, há indícios positivos, apontando possibilidades de inovação. A partir dos resultados obtidos, defendemos que se faz urgente a rediscussão dos saberes de física na formação inicial em suas formas, espaços, objetivos e valores. 



\section{ABSTRACT}

BARCELLOS. M. E. Physics teacher education program: physics knowledge and curriculum. 2013. 257f. Tese (doutorado) - Universidade de São Paulo, São Paulo, 2013.

In the last decades, special attention has been devoted to researches related to teacher role in education process and its professional qualifications. Government documents, like the "Diretrizes para a formação de professores da Educação Básica", published in 2002, called attention to the lack of connections between different approaches along teachers initial education programs. In the specific physics situation, this means that being a physics teacher must includes more than just learn physics and learn to be a teacher. In this frame of reference, we developed an investigation about how and which physics knowledge and other knowledge happen to integrate the curriculum of a physics teacher formation program. With this purpose, elements from curriculum theories and from teacher education proposals and reflections were discussed and incorporated. The investigations were developed in three interdependent scopes: (i) documents concerning educational general policies related to teachers programs as well as historical notes, (ii) results related to teachers education in the field of science learning researches and (iii) physics education curriculum, programs and courses (licenciaturas) in their self. In these different materials and moments we try to identify the aspects and selections concerning the physics knowledge that were being considered and which correlation was established in between this and the other knowledge to be a teacher. In almost all the cases that were analyzed we found that there is no discussion about which physics must be presented, as if there is just one and unique way of doing it. As a consequence, it means that the physics content remains unavailable to eventual changes and reproduces what is done in all physics undergraduate courses, granted by a casual epistemological science status. Our results indicate that the ultimate purposes of physics teaching are seldom considered, preventing from promoting a more autonomous teacher role. In this sense, we urge for a more comprehensive discussion about the kind of knowledge needed in the physics teacher education programs, including physics selections and organization, taking in account purposes, intentions and desired values to be promoted. 



\section{SUMÁRIO}

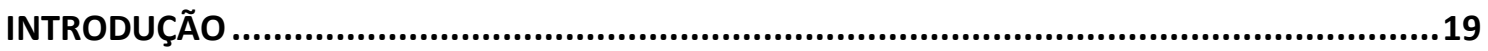

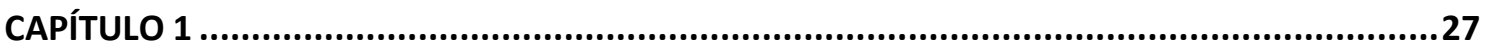

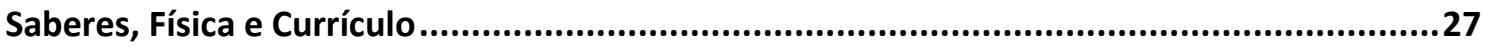

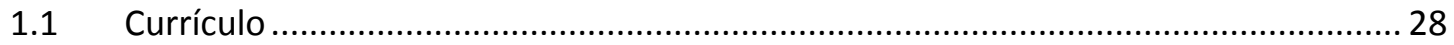

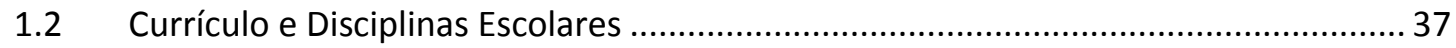

1.3 Disciplinas Escolares de Saberes Científicos ............................................................. 41

1.4 Saberes de Física e Formação de Professores............................................................... 46

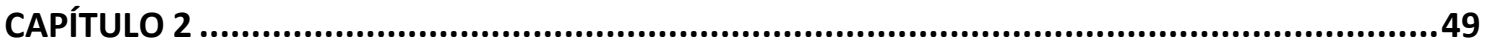

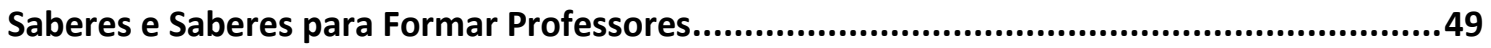

2.1 Saberes Específicos e Saberes Pedagógicos - Caracterização preliminar.................... 53

2.2 Um percurso pelos Saberes sobre os Saberes Docentes ............................................ 55

2.2.1 Saberes do professor segundo a concepção da Racionalidade Técnica .............. 57

2.2.2 Saberes que se sabem na Prática ........................................................................ 61

2.2.3 Saberes que não se sabem somente na prática.................................................66

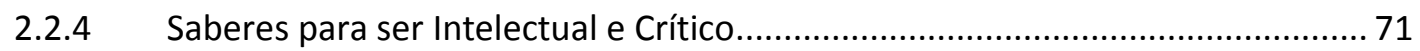

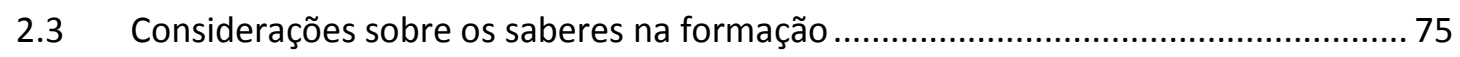

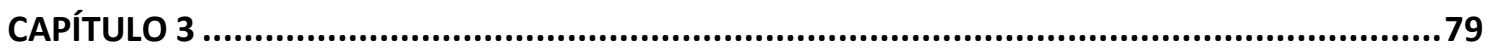

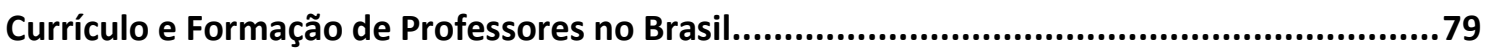

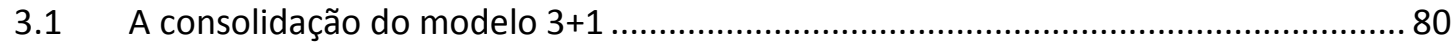

3.2 Breves considerações sobre as "Diretrizes Nacionais Curriculares para os Cursos de

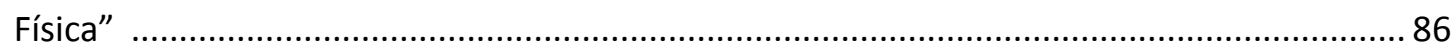

3.3 Modelos Atuais de Formação de Professores ........................................................... 87

3.3.1 A Instauração das Diretrizes Nacionais para Formação de Professores da

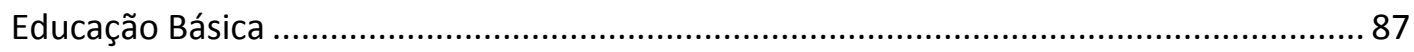

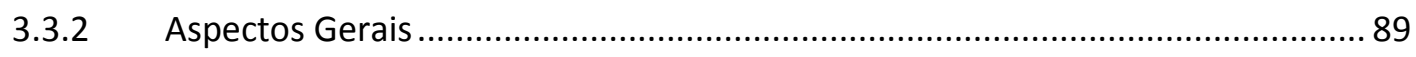

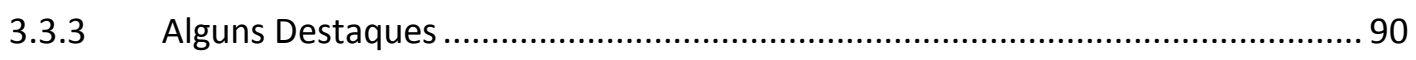

3.3.4 Significando as Diretrizes Nacionais para a Formação de Professores para a

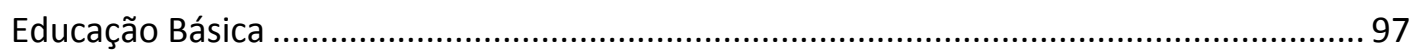

3.3.5 Breves consideraç̧̃es sobre a repercussão das diretrizes ................................. 103

3.4 Algumas considerações sobre o momento atual e os discursos oficiais.................... 106 
Formação de Professores, Educação Básica e Ensino de Ciências ......................................107

4.1 Algumas origens da Escola Secundária ................................................................. 108

4.2 Panorama a partir da Lei de Diretrizes e Bases da Educação Nacional de 1961 ....... 115

4.3 Algumas relações com a formação de professores.................................................. 121

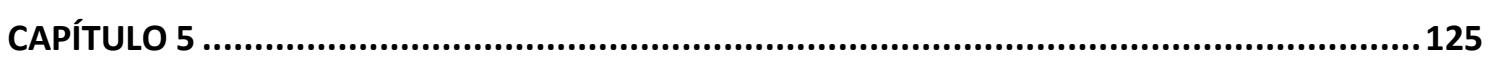

A Pesquisa em Ensino de Ciências e a Formação de Professores ......................................125

5.1 Estratégia de Investigação................................................................................. 126

5.2 Um Panorama das Pesquisas e a Licenciatura em Física ......................................... 128

5.2.1 Envolvimento do trabalho quanto à formação inicial de professores ............... 129

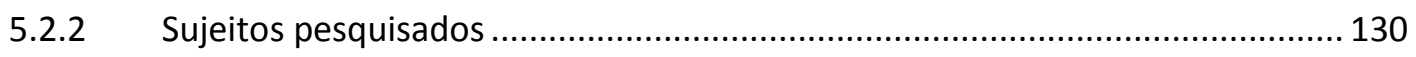

5.2.3 Núcleo-foco de atenção 7do trabalho quanto à formação do licenciando ....... 132

5.2.4 Concepção de professor explicitamente privilegiada ....................................... 133

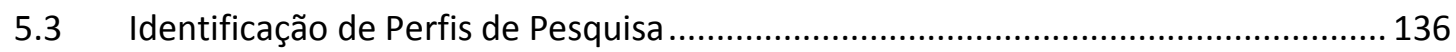

5.4 Considerações sobre a Pesquisa em Ensino de Ciências e a Formação de Professores .

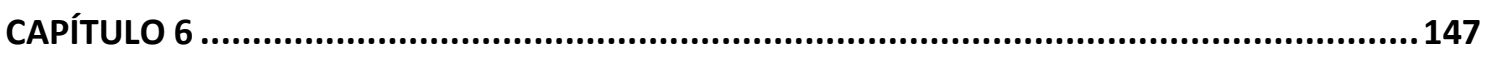

Formação Inicial de Professores de Física - Formatos e Perspectivas...............................147

6.1 O problema da desarticulação Saber Específico/Saber Pedagógico na Formação Inicial

- Perspectivas anteriores às Diretrizes de 2002 ................................................................ 149

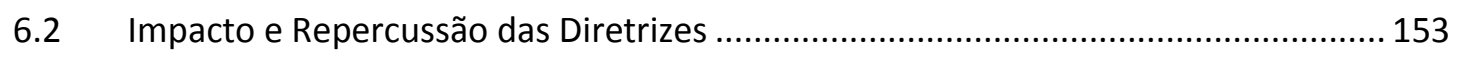

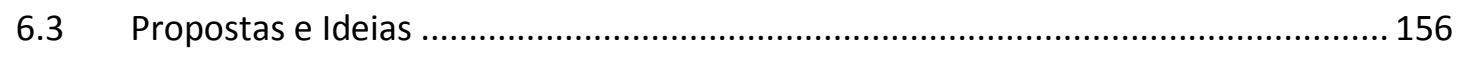

6.3.1 Aportes Curriculares Circunscritos ............................................................. 156

6.3.2 A Prática como Componente Curricular.......................................................... 158

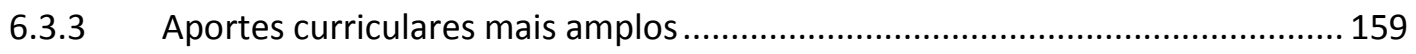

6.3.4 Considerações sobre as propostas e ideias..................................................... 160

6.4 Um Caso Referência - o Curso de Licenciatura do Instituto de Física da USP............ 161

6.5 Considerações sobre os Formatos e Perspectivas dos cursos de Licenciatura.......... 162

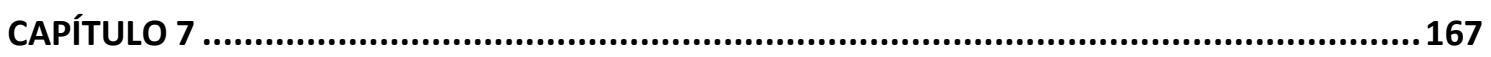

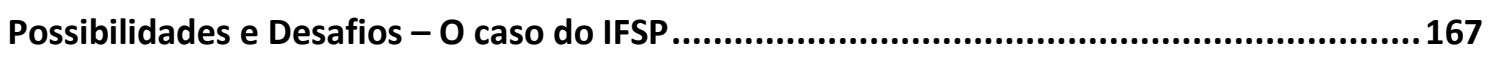

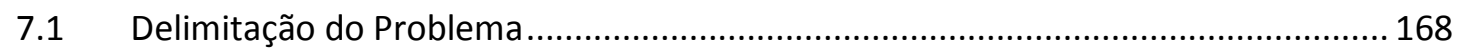

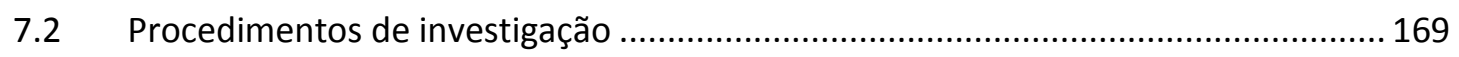

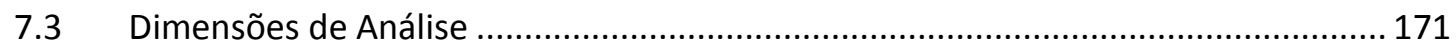

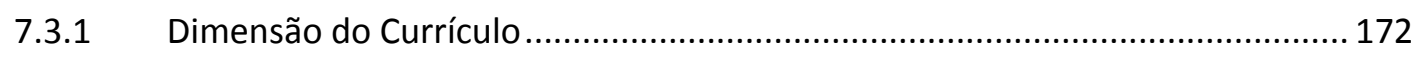

7.3.2 Dimensão da Prática e dos Saberes dos Professores ........................................ 183 
7.3.3 Dimensão dos Processos de Construção .......................................................... 189

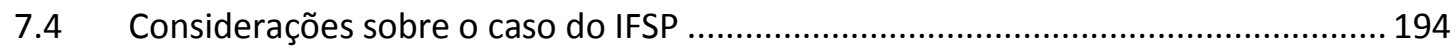

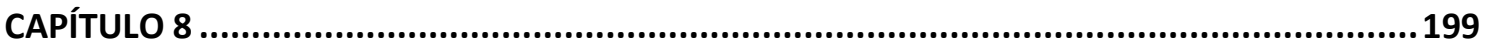

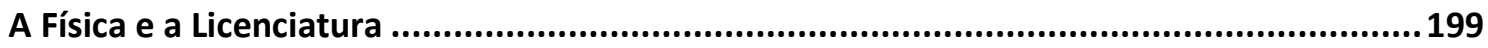

8.1 Saberes sobre Formação de Professores e Saberes sobre Currículo ......................... 200

8.2 A Física no Currículo da Licenciatura: suas finalidades ............................................. 201

8.3 Saber científico, Formação de Professores, Ensino de Ciências e a Escola Básica.... 205

8.4 Saberes, Física e Autonomia Docente ................................................................. 210

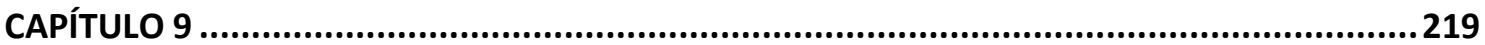

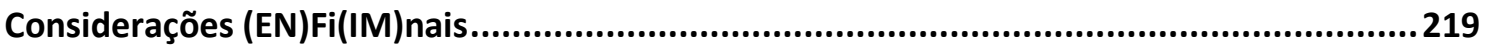

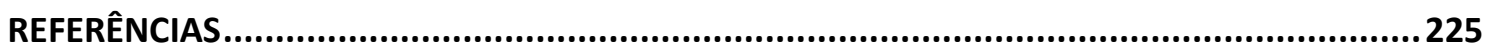

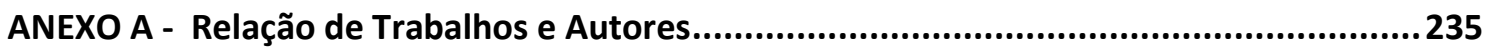

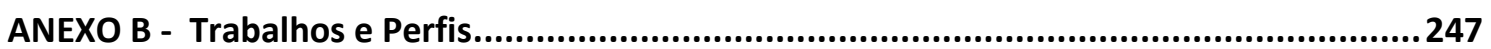

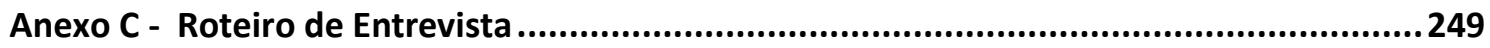

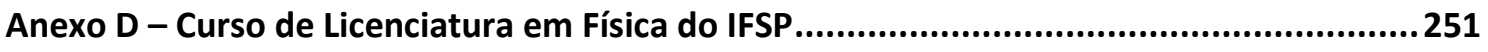

ANEXO E - Trabalhos e a Concepção de Professor .............................................................257 



\title{
INTRODUÇÃO
}

\author{
Escolhe teu diálogo \\ $e$ \\ tua melhor palavra \\ ou \\ teu melhor silêncio \\ Mesmo no silêncio e com o silêncio \\ dialogamos
}

Carlos Drummond de Andrade

A escola média brasileira vem passando por mudanças nas últimas décadas, tanto no quadro do perfil e das características dos jovens que a freqüentam, quanto na necessária rediscussão de seus objetivos e dos sentidos da educação que visa promover.

E para repensar essa escola, mais do que nunca, o papel do professor assume lugar central. Mesmo reconhecendo que a construção da identidade dos professores se dá ao longo de sua prática profissional, é preciso se debruçar, cada vez mais, sobre a formação inicial. E quando se considera a especificidade de cada área, ou seja, por exemplo, de um professor de Física para a escola média, a situação requer um tratamento ainda mais particular.

A problemática da formação de professores é presente e demarca espaços significativos dentro da pesquisa em Educação e da pesquisa em Ensino de Ciências. As políticas públicas, os saberes produzidos na área de educação e suas interfaces com as práticas concretas nos cursos das licenciaturas e demais instâncias formadoras são alvo de numerosas pesquisas.

Estudos completos e detalhados têm levantado o perfil e as principais características da formação de professores no Brasil, em vários níveis, como demonstram os estudos de Gatti (2008, 2009, 2010), Gatti e 
Barreto (2009), Andre at al (1999), Abib (1996), Gatti, Barreto e André (2011). Desses estudos têm emergido várias críticas à formação de professores predominante no Brasil dentre as quais: a característica fragmentária dos currículos dos cursos de formação e a falta de relação entre teoria e prática nesses espaços.

Especificamente em relação à formação inicial de Professores de Física, também encontramos críticas, como as sistematizadas por Abib (1997), que aponta a desarticulação dos saberes na formação e uma prática em sala de aula centrada em mecanismos de transmissão/recepção/fixação de um conteúdo pronto.

Em 2002, as novas "Diretrizes Curriculares Nacionais para a Formação de Professores da Educação Básica", respondendo a algumas das críticas consolidadas pelas pesquisas, vem exigir mudanças nos cursos de Licenciatura.

Essas diretrizes trazem à tona muitas reflexões sobre os problemas vigentes até então na formação de professores, relacionando-os com os problemas existentes na própria educação básica. A respeito do papel dos professores no processo educativo, o parecer destaca como desafio a ser enfrentado:

o preparo inadequado dos professores cuja formação de modo geral,
manteve predominantemente um formato tradicional, que não
contempla muitas das características consideradas, na atualidade,
como inerentes à atividade docente (BRASIL 2002, p. 4)

Entre os apontamentos que o parecer enfatiza, a fim de melhor preparar os professores para a atividade docente, na atualidade, fica muito explícito que a Licenciatura deve passar a assumir, inclusive como determina a Lei de Diretrizes e Bases da Educação Nacional (1996), terminalidade e integralidade própria em relação ao Bacharelado, constituindo-se em um projeto específico. Isso exigiria a definição de currículos próprios da Licenciatura que não se confundam com o Bacharelado ou com a antiga formação de professores, tradicionalmente caracterizada como modelo " $3+1$ " (BRASIL, 2002).

Outro aspecto, apontado como problema a ser superado na formação de professores oferecida até então, é a separação entre os conteúdos pedagógicos e os conteúdos específicos. Nas palavras do parecer: 
Nos cursos atuais de formação de professor, salvo raras exceções, ou se dá grande ênfase à transposição didática dos conteúdos, sem sua necessária ampliação e solidificação - pedagogismo, ou se dá atenção quase que exclusiva a conhecimentos que o estudante deve aprender - conteudismo sem considerar sua relevância e sua relação com os conteúdos que ele deverá ensinar nas diferentes etapas da educação básica. (BRASIL 2002, p. 21)

A Licenciatura em Física se enquadraria no conjunto de cursos que o parecer denomina de licenciaturas voltadas à formação de especialistas por área de conhecimento ou disciplina, que comumente tem em seu foco os conteúdos específicos da área, em detrimento de um trabalho mais aprofundado sobre os conteúdos que serão desenvolvidos na prática profissional do futuro professor.

Acrescenta-se a esse panorama, o quadro já conhecido, mas sinalizado de forma incisiva por pesquisas recentes, da falta de professores de física, o que tem levado a um movimento de proliferação dos cursos de Licenciatura em Física, incentivados pelas políticas públicas do governo federal (ARAÚJO e VIANNA, 2008; GOBARA e GARCIA, 2007). Essa proliferação tem se dado, inclusive, fora das estruturas universitárias, por exemplo, nos Institutos Federais de Educação Ciência e Tecnologia (GARCIA e HIGA, 2012).

O quadro geral dessas considerações sinaliza a necessidade de uma investigação específica em relação à formação de professores de física, procurando considerar particularmente algumas questões mais recentes. É preciso chamar a atenção para as especificidades do ser professor de física e não do ser só professor. Nesse sentido argumentamos pela necessidade de lançar um olhar específico, e ao mesmo tempo amplo, sobre o que tem sido feito na formação inicial de professores de física.

Entendemos que a física é um conhecimento que possui suas especificidades. Paralelamente, no modelo que prevalece, a formação do ser professor tem sido delegada às disciplinas oferecidas pelas faculdades ou departamentos de educação, ainda que as diretrizes curriculares venham trabalhando para reverter esse modelo.

Alinhados com as perspectivas de mudança já mencionadas, incluindo as novas "Diretrizes Curriculares Nacionais para a Formação de Professores da Educação Básica", assumimos que ser professor de física não 
é uma superposição de "aprender a ser professor" e "aprender física". Porém, delimitamos a hipótese de que, a despeito das mudanças exigidas nos últimos anos, os cursos de formação inicial, e os espaços de discussão que dele decorrem, não têm modificado nem problematizado os conteúdos de física, assim como a parte do currículo sobre a qual repousam esses saberes.

Perguntamos-nos então, já delimitando nossas questões de investigação: Qual é o papel dos saberes de física na formação do professor? Que espaços e formas esse saber ocupa nos currículos dos cursos de licenciatura? Que relações se estabelecem entre os saberes de física e os outros saberes presentes na formação inicial?

E buscando responder a essas questões optamos por situar essa investigação em um espaço de interface entre duas áreas: das teorias curriculares e da formação de professores. Pareceu-nos necessário entrelaçar alguns aportes trazidos por essas áreas de pesquisa para construir um arsenal teórico suficientemente amplo, que desse conta dos questionamentos que pretendemos investigar.

Podemos considerar que, de um ponto de vista geral, a formação inicial está diretamente vinculada aos cursos de licenciatura e a seus currículos, explícitos ou implícitos. Nesse sentido, e para além da legislação, orientações e diretrizes, os aportes das teorias de currículo podem contribuir para aprofundar ou esclarecer possíveis vínculos entre estruturas curriculares, organização em disciplinas, objetivos, finalidade e políticas educacionais mais amplas. E para além dessas, seus sentidos sociais mais abrangentes.

Ao mesmo tempo, o amplo e produtivo campo de pesquisa acerca da formação de professores vem investigando e refletindo sobre o ser professor e sua identidade, assim como sobre os elementos necessários para a construção desses aspectos. Inúmeros trabalhos têm tratado dessas questões, tanto de um ponto de vista mais geral, sobre os saberes docentes, como também discutindo questões mais específicas da formação de professores de física, das disciplinas de práticas, dos estágios, além do encaminhamento de ações e experiências concretas.

Nesse sentido, é no âmbito das discussões dessas duas áreas que buscaremos investigar como vem sendo tratada a questão dos conhecimentos específicos de física na formação de professores, na tentativa 
de trazer novos subsídios para a reflexão acerca dos cursos de licenciatura.

No que concerne ao campo das questões curriculares, construiremos um aporte que se apoia nas teorias críticas do currículo e, portanto, o nosso olhar para a seleção e organização dos saberes na formação inicial do professor se dará em uma perspectiva epistemológico social (SILVA, 2010). Buscaremos caracterizar algumas compreensões sobre os currículos, aprofundar o papel das disciplinas escolares e ainda construir algumas relações entre as disciplinas, o currículo e o conhecimento físico.

No que concerne ao campo da formação de professores, segundo classificação proposta por André et al (1999), situamos esse trabalho no grupo das pesquisas sobre a formação inicial de professores e com enfoque em cursos de licenciatura, ou seja, na formação inicial de professores especialistas por área de conhecimento. Faremos um percurso perpassando várias possíveis compreensões sobre o que significa "ser professor", diante das quais procuraremos entender o papel dos saberes de física, suas relações com os saberes pedagógicos e as configurações aí presentes.

A partir do estudo dos aportes teóricos que selecionaremos dentro dessas duas grandes áreas, construiremos nosso referencial teórico.

Munidos desse referencial teórico adentraremos a pesquisa em três âmbitos de investigação por nós delimitados, num percurso que vai de um panorama geral da formação de professores, e das questões curriculares mais abrangentes, até aspectos mais concretos, culminando numa etapa em que nossa pesquisa se dará sobre o caso específico de um dado curso de licenciatura.

Os três âmbitos de pesquisa por nós delimitados são:

- o âmbito das "políticas públicas mais gerais, incluindo documentos oficiais e legislações atuais" (capítulos 3 e 4);

- o âmbito da "comunidade de pesquisa da área, expressa pelas pesquisas em ensino de ciências em anos mais recentes" (capítulo 5),

- o âmbito dos "espaço de concretização das práticas, expressa na estrutura e formação nos cursos de licenciatura" (capítulos 6 e 7).

No âmbito de investigação que diz respeito aos "documentos 
oficiais", faremos uma análise das leis e diretrizes curriculares e de alguns registros históricos, buscando elementos que nos permitam mapear como os saberes se estabeleceram nos currículos de formação de professores, como os saberes de física e os saberes pedagógicos se articulam nessa formação, quais as relações que podemos perceber com a escola básica e seus currículos, e quais as perspectivas e tendências que se consolidaram nesses processos.

No que concerne ao âmbito da "pesquisa em ensino de ciências", buscaremos, por meio da análise de artigos em eventos da área, mapear as relações entre os saberes que compõem o repertório do professor e caracterizar perfis de pesquisa, dentre os trabalhos que de alguma forma permeiam a temática da licenciatura.

Em relação ao âmbito da "formação nos cursos de licenciatura", tratar-se-á. em um primeiro momento, de um olhar mais focado nas pesquisas existentes sobre os cursos e currículos das licenciaturas, sempre da perspectiva de compreender a articulação dos saberes e o espaço delimitado pelos saberes de física. Nessa etapa, aproximaremos nossa perspectiva de situações mais específicas, em processos reais de reformulações curriculares, nos impactos das leis e diretrizes em cursos propriamente ditos, e nas ideias e concepções que vão se consolidando a partir dos movimentos que incorporam elementos da prática, do discurso oficial e da pesquisa. Nossa investigação incluirá, também, o estudo das questões desenhadas em um caso concreto e específico, o curso de licenciatura em física do Instituto Federal de São Paulo.

Por fim, procuraremos resgatar elementos construídos ao longo do percurso, na pretensão de refletir sobre o problema da formação nas licenciaturas, buscando trazer elementos que possam contribuir para esses processos e práticas e para novos olhares de pesquisa. Nessa etapa traremos à tona de forma sistematizada os resultados dessa investigação tentando encadear a argumentação que sustenta a tese que procuraremos defender.

Em síntese, a estrutura de apresentação dessa tese inclui os momentos detalhados a seguir, capítulo por capítulo.

O capítulo um apresenta o prelúdio do aporte que pretendemos lançar sobre a questão da formação de professores, na qual as 
teorias de currículo desempenham um papel fundamental. Configuraremos algumas noções existentes a respeitos dos currículos, aprofundando algumas teorias que se mostraram interessantes para o nosso problema de pesquisa. Passaremos então a uma reflexão sobre as disciplinas escolares, e na sequência tentaremos fazer alguns vínculos que tentam levar em conta a especificidade do conhecimento científico e mais ainda do conhecimento físico.

O capítulo dois é um olhar para os saberes produzidos pela área da formação de professores. Primeiramente desenharemos um aporte para os saberes, centrados na noção de saber específico e saber pedagógico. A partir disso passaremos a mapear como se configuram esses saberes em algumas diferentes concepções sobre os professores.

No capítulo três, já munidos dos aportes teóricos desenhados nos capítulos um e dois, adentraremos aos âmbitos de investigação. Começaremos por focalizar os âmbitos oficiais e suas ações em termos da formação de professores. Para tanto faremos um breve percurso histórico buscando a compreensão dos processos pelos quais se estabeleceram padrões e se consolidaram tendências na formação de professores. Em seguida passaremos ao nosso foco principal de análise que são as vozes presentes nos documentos oficiais atuais que regem a formação docente. Trazemos uma reflexão detalhada sobre as novas Diretrizes Curriculares de 2002, e sobre suas possibilidades enquanto indutora de novas práticas, principalmente no que concerne à questão dos saberes e como se orquestram nos currículos das licenciaturas.

Já no capítulo quatro, ainda dentro da investigação do âmbito do discurso oficial, buscaremos elementos que nos permitam entender um pouco melhor as relações existentes entre a formação de professores, o ensino básico e o ensino de ciências. Para isso apresentaremos novamente um breve percurso histórico.

No capítulo cinco tentaremos caracterizar lugares e formas que os saberes presentes na formação do professor ocupam, em investigações diversas da área de pesquisa em Ensino de Ciências cuja temática permeie a licenciatura em física. Aí se delineia o âmbito de investigação da pesquisa em ensino de ciências. 
Já as pesquisas que se debruçam sobre os impactos das diretrizes curriculares nos cursos de licenciatura e seus saberes serão objeto de análise mais detalhada no capítulo seis, onde adentraremos então, ao âmbito da formação nos cursos de licenciatura.

E para compreender mais concretamente 0 âmbito da formação nos cursos de licenciatura optamos pela realização de um estudo em caso, que apresentaremos no capítulo sete. Esse estudo consistiu no olhar para uma instituição específica, uma realidade concreta, na qual pretendemos aprofundar alguns aspectos levantados ao longo do trabalho. Buscaremos ainda, nesse caso, análises que possam nos dar indicadores sobre reais possibilidades de articulação entre os saberes na formação, e sobre a viabilidade da implementação de propostas inovadoras.

No capítulo oito traremos uma sistematização dos resultados mapeados ao longo da pesquisa a partir da qual elencamos os argumentos que remontam nossa tese. Essa tese consiste na defesa da necessidade de uma desnaturalização dos saberes de física inerentes aos currículos das licenciaturas, e da necessária rediscussão desses saberes na formação inicial, em suas formas, espaços e valores.

Por fim, o capítulo nove trará as considerações finais desse trabalho, pretendendo refletir sobre os limites dessa pesquisa e sobre as contribuições que pretensamente deixará à formação de professores de física. 


\section{CAPÍTULO 1}

\section{Saberes, Física e Currículo}

O homem não é de modo nenhum a soma do que tem, mas a totalidade do que não tem ainda, do que poderia

ter

Jean-Paul Sartre

A investigação que pretendemos estabelecer acerca da formação de professores tem uma relação direta com os conhecimentos que são selecionados e incorporados nas propostas dos cursos de licenciatura, ou seja, com o currículo, as disciplinas e o conhecimento de física apresentado nesses cursos. Nesse sentido, focaremos inicialmente nosso olhar na temática do currículo, buscando identificar diferentes formas de encarar a presença dos conhecimentos no cerne desse processo.

A despeito da pouca interface existente entre a área de pesquisa em currículo e a de pesquisa em ensino de ciências, nossa reflexão sobre a formação de professores não seria possível sem a construção de um aporte de cunho mais teórico, que nos permita adentrar a problemática do conhecimento específico da física e os espaços e formas que esse conhecimento ocupa no currículo.

Nesse sentido, buscaremos delinear uma noção de currículo que nos permita problematizar os conhecimentos veiculados e as diferentes, formas pelas quais esses conhecimentos são estruturados, passando pela problematização da organização disciplinar específica. Ou seja, pretendemos identificar instrumentos para problematizar o sentido das disciplinas e, mais diretamente, das disciplinas específicas que, no nosso caso, condicionam a existência de um curso de licenciatura em física.

Abordaremos, ainda, algumas questões epistemológicas 
referentes ao próprio conhecimento físico, buscando desvelar algumas das relações que se estabelecem entre o saber acadêmico e o saber objeto de ensino.

\subsection{Currículo}

Seria difícil estabelecer uma definição única do que seja currículo. A noção mais comumente difundida, talvez, seja a visão do currículo como uma relação de "matérias" a serem estudadas pelos alunos, em determinado nível de ensino.

Segundo Messick et al (1980), um indivíduo que passa pela profissionalização, no magistério, toma contato com várias concepções de currículo, dentre as quais: currículo são todas as atividades que o aluno desenvolve na escola; currículo é um manual preparado por alguma instância governamental; currículo é o programa previsto em lei; currículo é o que um professor ensina a seus alunos em determinada disciplina.

Segundo Silva (2010) "as professoras e professores de todas as épocas e lugares sempre estiveram envolvidos, de uma forma ou de outra, com o currículo, antes mesmo do surgimento de uma palavra especializada como "currículo" pudesse designar uma parte de suas atividades" (p. 21).

Compreensões genéricas, como essas, refletem, implicitamente, uma percepção restrita do próprio currículo e a importância de um aprofundamento sobre seus vários significados e implicações nas práticas cotidianas.

A palavra "Currículo" segundo Goodson (2008a) vem da palavra latina Scurrere que significa correr e refere-se a curso. Assim, surge a noção de um curso a ser seguido. Uma implicação dessa compreensão, nas palavras do autor é de que: "O vínculo entre currículo e prescrição foi, pois, forjado desde muito cedo, e, com o passar do tempo, sobreviveu e fortaleceuse" (p. 31).

Como destaca Silva (2010), a própria emergência da palavra currículo, com o sentido que modernamente se atribui a este termo, está ligada a preocupações de organização e método.

Como conceito associado à escolarização, o currículo parece ter emergido na época em que a educação estava se transformando em 
atividade de massa, assim como o conceito que define a divisão dos alunos em classes e turmas (GOODSON, 2008; SILVA, 2010). Segundo Goodson (2008a), "a organização em classes foi associada ao currículo prescrito e seqüenciado em estágios ou níveis” (p. 32).

O currículo como objeto de estudo data do início do século XX. Bobbitt (apud SILVA, 2010), em 1918, define o currículo como uma especificação precisa de objetivos, procedimentos e métodos para obtenção de resultados que possam ser precisamente mensurados. Essa definição é inspirada no processo fabril (SILVA, 2010, p.13) e, de certa forma, já inclui uma relação explícita entre objetivos e resultados.

Para Ralph Tyler, em Princípios Básicos de Currículo e Ensino, cuja publicação original data de 1949, a elaboração de um currículo deve levar em conta tensões e respostas a perguntas amplas sobre educação.

A despeito das numerosas críticas que virá a receber depois, sua obra constitui uma espécie de "manual" acerca de como construir um currículo. Nesse sentido, nos será útil destacar algumas de suas contribuições, visto que, ao contrário de muitos outros autores e tendências posteriores, ele oferece subsídios efetivos para quem tenha a missão de elaborar um currículo, e, por isso, é um autor que exacerba uma preocupação eminentemente prática.

Para Tyler (1989), na construção de um currículo devem se conciliar tensões, provenientes de visões teóricas distintas, a respeito da escola e do conhecimento. Ele caracteriza três correntes teóricas importantes das quais devem derivar os objetivos educacionais. E é somente após definidos esses objetivos, que se deve delimitar os conteúdos, os métodos e os procedimentos segundo os quais o currículo será avaliado.

As três correntes teóricas apresentadas por Tyler (1989) são:

Essencialista - assume a visão de que a escola deve promover a aprendizagem básica de conhecimentos selecionados do tesouro cultural acumulado pela humanidade ao longo da história.

Progressista - argumenta que a aprendizagem deve se centrar em atender aos interesses e necessidades imediatas dos alunos, promovendo, assim, o seu progresso, de acordo com as fases de desenvolvimento do indivíduo. 
Sociológica - caracteriza a complexidade da vida moderna e defende focalizar esforços educacionais sobre aqueles aspectos considerados como tendo especial importância na vida contemporânea.

Tyler defende que nenhuma dessas perspectivas, sozinha, poderá oferecer a melhor solução ao problema educacional e que se deve buscar sempre uma mediação entre elas. Nesse sentido, o currículo passa a expressar um acordo implícito entre diferentes intenções formativas.

$\mathrm{O}$ autor traz ainda uma reflexão específica sobre o papel dos especialistas e dos conteúdos disciplinares na elaboração dos currículos. Segundo ele, os especialistas que propõem objetivos educacionais, muitas vezes, parecem responder à pergunta: "Qual deve ser o ensino elementar para estudantes que terão que realizar posteriormente um trabalho muito mais avançado no campo?' (TYLER, 1989, p.23). Em contrapartida, ele defende que esses mesmos especialistas deveriam tentar responder à pergunta: " $D e$ que forma sua disciplina pode contribuir para a educação dos jovens que não se destinam a ser especialistas no seu campo? Qual pode ser a contribuição da sua disciplina para o leigo, o cidadão comum?' (TYLER, 1989, p.24). Essa reflexão, em particular, nos parece muito relevante e atual.

Por outro lado, em sua obra, o autor utiliza, por exemplo, de recorrências freqüentes ao conceito de "eficácia", restringindo compreensões do que seriam os possíveis âmbitos dos currículos. No entanto, uma vez que se contextualizem historicamente suas reflexões, não acreditamos que esse aspecto o transforme em ícone da concepção tecnicista de currículo, ao contrário do que é mencionado por diversos autores (SILVA, 2010, KLIEBARD, 1980). Corroborando nossa compreensão, há, em seu texto, recorrências e menções a situações de educação indígena e escolas comunitárias, bem como a objetivos educacionais envolvendo melhoria das condições de saúde e higiene, utilização e conservação das riquezas naturais e etc, que consideramos, até mesmo, como bastante atuais e longe do tecnicismo.

Tyler, ainda, questiona de forma explícita alguns fatores cruciais sobre a função da escola (que o serão inclusive para as teorias críticas), deixando perguntas a serem respondidas por possíveis elaboradores do currículo como: "O que se pretende é a adaptação ou a transformação da 
sociedade?" ou "...A educação deve ser comum a todos ou diferenciada?" (TYLER, 1989, p. 32).

Em relação à sua pertinência dentre os teóricos não críticos, concordamos com Moreira (1997), quando afirma que:

Em seu livro mais divulgado, Tyler, assim como Dewey, considera
"boa sociedade" e a "sociedade capitalista democrática" como
expressões sinônimas, não questionando, assim as injustiças da
sociedade capitalista. Por outro lado, Tyler deseja que a escola
contribua para a reprodução dos valores aceitos pela classe média
americana, propondo em troca, que desenvolvam atitudes sociais
positivas e que se faça com que a "escola esteja em harmonia com
essas atitudes em vez de impor arbitrariamente um determinado
conjunto de opiniões mantidas por um certo grupo de professores
(MOREIRA, 1997, p.64).

O fato de a questão central do currículo, para Tyler, serem os objetivos educacionais e não os conteúdos ou as áreas acadêmicas, sinaliza elementos importantes para nossa atual discussão.

Tyler, ainda, nos deixa uma interessante questão no que diz respeito ao advento da modernidade e às complexidades que essa vem a criar na definição dos saberes escolares. Segundo esse autor, antes da ciência moderna e da revolução industrial, "o conjunto de conteúdos então considerados academicamente respeitáveis era suficientemente pequeno para que não houvesse grandes problemas em selecionar os elementos de maior herança cultural" (TYLER, 1989, p. 15).

Já como representante exemplar da teoria tecnicista dos currículos, mais próximo à asserção definida por Bobbitt e citada acima, incluímos a obra de Jerome Bruner, psicólogo americano, reconhecido por suas contribuições à psicologia cognitiva. Sua análise sobre o currículo centrase, basicamente, na perspectiva das contribuições das áreas científicas para o ensino. Tomando como referência as teorias sobre o desenvolvimento da criança, Bruner (1987) defende que qualquer assunto pode ser ensinado em qualquer idade, desde que a abordagem do ensino seja realizada de forma adequada.

Nesse sentido argumenta que os assuntos científicos deveriam ser introduzidos o mais cedo possível na escola, de forma honesta e correta do ponto de vista conceitual, a fim de que ao longo dos anos de escolaridade, esses conhecimentos possam vir a ser retomados com graus de 
profundidade cada vez maiores. É a proposta do chamado currículo em espiral.

Embora a preocupação com os objetivos sociais da escola, ainda que de forma periférica, apareça em sua obra, Bruner defende, centralmente, o papel do especialista na elaboração do currículo. No seu entender, só um profundo conhecedor do conhecimento científico seria capaz de buscar formas alternativas e adequadas de introduzir um assunto em diferentes níveis. $\mathrm{E}$, nesse sentido, argumenta fortemente em prol de uma aprendizagem que preserve a estrutura fundamental de determinado conhecimento de referência. Esse parece ser, de fato, o principal objetivo de ensino que estaria subjacente à sua concepção educativa.

Em suas asserções a projetos educacionais de sucesso, 0 autor cita o PSSC ${ }^{1}$, e exalta sua intenção no sentido de diminuir a distância entre o conhecimento avançado e o conhecimento elementar (BRUNER, 1987, p.23). Isso fica explícito em suas considerações :

... a intenção modesta de realizar um melhor trabalho no ensino de física (...)o que levou um grupo de físicos da mais alta competência a unir-se nesse esforço comum foi o sentimento de quão grande era a lacuna aberta entre a física como o físico a conhece e a física como é ensinada na escola, lacuna essa de particular importância, devido aos avanços revolucionários da ciência e a crise de segurança nacional (BRUNER, 1987, p.66).

Para Bruner, o professor ocupa uma posição periférica no processo de definição curricular e há de se investir em vídeos e materiais educativos a fim de instrumentalizá-lo para que ele realize o ensino de modo eficiente. Em sua obra, ainda, são abordadas questões sobre os alunos menos capazes e de realidades "inconvenientes" que inibem o desenvolvimento intelectual, ressaltando que esses alunos devem ser ajudados a atingirem seu "melhor possível".

A educação para Bruner tem, também, uma clara acepção propedêutica, explicitada em uma preocupação que se sobrepõe a outras:

E quaisquer que sejam os limites impostos à educação, pela solicitação de diversidade e uniformidade, há também exigências referentes à produtividade que devem ser atendidas: estaremos nós produzindo pensadores, cientistas, poetas, legisladores em número suficiente para satisfazer as solicitações de nosso tempo? (BRUNER, 1987, p.8)

\footnotetext{
${ }^{1}$ Physical Science Study Committee - projeto de ensino de física desenvolvido na década de sessenta.
} 
Essa visão tecnicista de Bruner apresenta, portanto, em nossa análise, um claro interesse em controle do processo educativo, no qual o especialista domina o processo, visando maximizar o rendimento da aprendizagem. Está presente, ainda, uma visão elitista de conhecimento, no qual os saberes acadêmicos, com reconhecimento científico universal, são inquestionavelmente os saberes mais válidos e dignos de serem ensinados na escola. E isso é tratado como natural, assim como as desigualdades sociais, e o fato de existirem alunos menos capazes.

Podemos perceber que dentre esses autores há, de uma forma ou de outra, uma discussão mais explícita sobre os saberes acadêmicos disciplinares específicos e o papel que podem desempenhar no currículo. Dentre essas claras asserções ao papel dos conteúdos, ressaltamos diferenças. Enquanto na perspectiva trazida por Tyler, o conhecimento especializado deve de alguma maneira, servir ao leigo, ao cidadão comum, na perspectiva de Bruner, o aluno deve chegar mais perto de compreender a física como ela é para os físicos, por exemplo.

Outras concepções bastante distintas das teorias tradicionais de currículo, como as apresentadas até aqui, emergem de pressupostos sociais e políticos mais amplos, sendo conhecidas como teorias críticas do currículo.

Segundo Silva (2010), as teorias críticas argumentam que nenhuma teoria sobre o currículo é neutra e que está sempre implicada de relações de poder. Como decorrências dessas relações, as questões que assumem um papel preponderante seriam, então, relativas ao "Por que ensinar?" e não tanto ao "O quê ensinar?", na medida em que assim se reconhecem mais explicitamente conexões entre saber, identidade e poder (SILVA 2010). Nesse sentido, nos deteremos na ênfase de que, para os que compartilham dessas teorias críticas, as questões que definem quais conhecimentos devem ser ensinados não são de natureza apenas epistemológica.

As teorias críticas de currículo têm algumas de suas raízes no movimento de questionamento do currículo tradicional, desencadeada pelas abordagens educacionais de cunho sociológico. Segundo Moreira (2010a), a partir das abordagens críticas, desencadeia-se um movimento de 
reconceptualização do campo do currículo, que gira em torno da rejeição do caráter prescritivo prevalente, da certeza da não neutralidade das decisões curriculares, da importância de contextos mais amplos para o entendimento dos currículos, e da crença na importância da escola no processo de construção de uma sociedade mais democrática e justa.

Diante dessa nova abordagem, para as teorias de currículo, e principalmente da negação de seu caráter prescritivo prevalente, podemos problematizar o que seja o conceito de currículo, incorporando muitos outros âmbitos de discussão. Nesse sentido, é preciso reconhecer que o currículo prescrito, documentado, ou oficial é apenas uma parte da história. Há de se reconhecer que existem processos de negociação e que a realização prática do currículo, por instâncias do Estado, governo, professores, alunos e escolas apresentam muitos outros elementos de análise. Assim, não é possível mais compreender o currículo como um corpo neutro, acadêmico e desinteressado (ou bem intencionado), organizado por meio de um processo que recorre a fontes imparciais ou a valores supostamente consensuais da sociedade.

Uma das concepções ícones da tendência crítica do currículo é aquela proposta pelo autor norte americano Michel W. Apple. Em seu trabalho, fica muito clara a marca de que o conhecimento corporificado no currículo é o resultado de um processo que reflete interesses de grupos e pessoas (APPLE, apud SILVA 2010, p.46). Apple (1994) enfatiza que as teorias, diretrizes e práticas envolvidas na educação não são puramente técnicas. São intrinsecamente éticas e políticas e, em última análise, envolvem escolhas profundamente pessoais em relação ao que seja o bem comum.

Apple (2006) em sua obra "Ideologia e Currículo", identificando as escolas como mecanismos de transmissão cultural, argumenta exatamente sobre o papel dessa instituição para ampliação da dominação ideológica de determinadas classes sobre outras. $E$ isso se dá porque a realidade do que as escolas e outras instituições culturais selecionam, preservam e distribuem não necessariamente serve aos interesses de todos os indivíduos e grupos da sociedade.

Segundo Apple (2006) a maioria dos educadores tem a tendência de perceber o conhecimento como um artefato relativamente neutro. No entanto ele enfatiza que o currículo das escolas responde a recursos 
ideológicos e culturais que vêm de algum lugar e os representa. Segundo essa visão, o conhecimento que chega às escolas não é aleatório. É selecionado e organizado ao redor de um "conjunto de princípios e valores que vêm de algum lugar, que representam determinadas visões de normalidade e desvio, de bem e de mal" (p.103).

Assim, são estabelecidas relações entre o currículo e a reprodução cultural e econômica, por meio de manutenção e do controle de formas particulares de ideologia. Nas palavras do autor:

O ensino aberto e oculto de algumas visões de ciência e de vida
social fazem com que seja bastante difícil estar ciente da saturação
ideológica que ocorre, pois, se os "fatos" do mundo realmente
repousam sobre nossas teorias a respeito deles, então o mundo que
as pessoas vêem e os significados econômicos e culturais que dão a
ele serão definidos de tal maneira que passam a ser autojustificáveis.
Dão-se significados sobre como o mundo "realmente é" e também se
legitimam os interesses econômicos e culturais que determinam por
que ele é assim. A função ideológica é circular. O poder e o
conhecimento estão aqui íntima e sutilmente conectados por meio
das raízes de nosso senso comum, por meio da hegemonia. (Apple,
2006, p. 145)

E nessa mesma direção se encaminham algumas outras críticas ao campo tradicional do currículo, dentre as quais, segundo Apple, estão suas limitadas formas de percepção ou consciência. Nesse sentido, os pressupostos políticos e ideológicos que sustentam boa parte de seus modelos normais de atividade estão tão ocultos quanto aqueles com os quais os alunos de deparam nas escolas.

O autor defende que se deve deixar claro que a elaboração do currículo e a criação de ambientes educativos, nos quais os alunos deverão conviver, são inerentemente um processo político e moral. E nesse sentido traz à tona que as escolas, tal como são atualmente, simplesmente não atendem às necessidades de boa parte da população (APPLE, 2006).

$E$ isso acontece porque as escolas, enquanto instituições, estão interligadas a outras instituições políticas e econômicas que dominam a coletividade. E que, frequentemente, agem sem questionamentos, ao distribuir conhecimentos e valores por meio dos currículos, os quais em geral atuam para sustentar essas mesmas instituições. Ainda, segundo argumenta Apple, há de se reconhecer que essa configuração tem íntima relação com determinadas formas de divisão social do trabalho (Ibidem). 
Esse tipo de "denúncia" é marca característica do ponto de vista crítico uma vez que, a partir dessa forma de olhar, segundo Apple, sempre se deve considerar um objeto "relacionalmente". Isso significa investigar algo sempre em relação às suas raízes históricas (como evoluiu, em que condições surgiu) e procurando observar seus laços menos explícitos.

Nesse sentido o autor defende a forma crítica de atuar como opção de emancipação:

o ato da crítica contribui para a emancipação, ao demonstrar o caminho pelo qual as instituições sociais e lingüísticas foram reificadas ou coisificadas, a ponto de os educadores e o público em geral terem esquecido por que tais instituições são como são, e que foram as pessoas que as construíram e que, portanto, podem mudálas. (Apple, 2006, p. 183)

Ainda nesse cenário, delimitado pelas tendências críticas, destacamos a problematização sobre o currículo que se faz presente na obra do autor francês Jean-Claude Fourquin. Em "Escola e Cultura" (1993), o autor chama a atenção para os elementos constitutivos do conhecimento escolar e para a cultura como "substância" do processo educativo. Nesse sentido, é possível delimitar que a escola está imersa na cultura e é tanto seu reflexo, como um de seus mais importantes mecanismos de continuidade.

Para Fourquin (1992), currículo é o termo que designa as seleções que as escolas e docentes fazem no interior da cultura, decidindo o que será ou não objeto de ensino. Segundo o autor, a cultura, em dado momento histórico, permitiria sempre um número quase ilimitado de combinações possíveis e é preciso optar por uma dada seleção para construir um currículo.

Dentre as inúmeras possíveis definições de cultura, podemos situar o que seria essa cultura, "substância" do processo educativo, dentre dois extremos que são: a definição elitista (cultura como qualidade do espírito cultivado) e a definição antropológica de cultura (cultura como tudo o que caracteriza um modo de vida). No que se circunscreve à função de transmissão cultural característica da atividade educativa, uma definição pertinente de cultura, nas palavras de Fourquin, seria:

Essencialmente, um patrimônio de conhecimentos e de competências, de instituições, de valores e de símbolos, construído ao longo de gerações e característicos de uma comunidade humana 
particular, definida de modo mais ou menos amplo e mais ou menos exclusivo. (FOURQUIN, 1993, P. 12)

E essa definição entre o "mais ou menos ampla" e o "mais ou menos exclusiva" é, justamente, travada por mecanismos de seleção, resultando em um conjunto de saberes que é legitimado para ser ensinado na escola.

No que concerne a nosso problema de pesquisa, especificamente em relação ao ensino de física e à formação de professores, direcionaremos nosso olhar, assim como também o faz Fourquin (1992) para a "matérias" ou disciplinas escolares e seu papel na organização e seleção dos saberes.

\subsection{Currículo e Disciplinas Escolares}

Segundo Fourquin (1992), a organização do conhecimento escolar sob a forma de matérias ou disciplinas é uma das "características morfológicas essenciais" do saber escolar (p. 37). É, então, extremamente pertinente nos perguntarmos sobre os mecanismos de seleção que operam dentro e fora das fronteiras das disciplinas escolares e quais são os fatores que influenciam esses processos.

Alguns autores têm se ocupado de análises dessa natureza, dentre os quais ressaltamos A.Chervel e I.Goodson, com ênfase em abordagens que incluem a "História das Disciplinas Escolares", ainda que com perspectivas diferentes. Goodson faz suas análises a partir da sociologia e história do currículo, enquanto Chervel utiliza a história da educação e da cultura escolar (AIRES e ERN, 2005).

Goodson (1990), assumindo a perspectiva crítica de currículo, argumenta que falta a esse movimento uma compreensão mais completa $e$ detalhada de como os processos de dominação e controle são exercidos. Nesse sentido suas pesquisas irão buscar, por meio do estudo da história do currículo e das disciplinas escolares, exatamente essa compreensão.

A visão que, segundo Goodson (1990), é hegemônica entre os professores e a sociedade em geral, é a de que uma disciplina acadêmica é traduzida em matéria escolar. A análise do processo histórico de surgimento e evolução das disciplinas escolares, no entanto, dá indícios contrários. 
Goodson (1990) evidencia que o contexto escolar é muito distinto do contexto acadêmico e fatores muito diferentes interferem na sua construção. Seus estudos evidenciaram até mesmo casos de disciplinas escolares que não só não se originaram de áreas acadêmicas como as precederam.

$\mathrm{Na}$ obra Currículo Teoria e História, Goodson (2008a) descreve os processos pelos quais as "matérias escolares" se relacionam com as respectivas "disciplinas acadêmicas". Segundo ele, a evolução de cada matéria reflete, em microcosmo, "uma luta em torno de sucessivas alternativas, discriminadas à medida que a escolarização estatal se estabelece e se define"(p. 37). Nesse sentido destaca que:

A medida que a matéria avança o papel das universidades se torna
cada vez mais importante. A coisa não para por aí, porque cada
grupo emprega o seu discurso na tentativa de que sua matéria seja
considerada "disciplina acadêmica" (merecedora, por isso, de
recursos financeiros e oportunidades de carreira que vão se
acumulando). O corolário desta reivindicação é que os pesquisadores
universitários devem adquirir o controle sobre a
"disciplina"(GOODSON, 2008a, p. 38).

Por outro lado, a abordagem apresentada por Chervel (1992), que é mais centrada no conceito de cultura escolar, procura trazer à tona a investigação de como a escola produz suas disciplinas. E, nesse sentido, coloca-se a questão das finalidades dessas produções.

$E$ é na questão das finalidades que reside outro importante aspecto, essencial à compreensão do que ocorre no sistema escolar. A escola ensina suas "próprias" produções, e, segundo Chervel, "seu verdadeiro papel pode estar em outro lugar, que não é o de querer servir de reposição para alguns "saberes eruditos"' (CHERVEL, 1992, p. 182).

A dificuldade reside no fato de que, na maior parte do tempo, a escola "ensina" um certo número de matérias da qual a natureza não é de modo algum problemática. Mas, na verdade, as disciplinas são dispositivos que "colocam um conteúdo a serviço de uma finalidade educativa" (CHERVEL, 1992, p. 183). Essas finalidades, no entanto, só ficam explícitas e claras em momentos de reformas educacionais, em que se desarranjam os cursos e disciplinas. Somente quando novos objetivos são impostos pela conjuntura política ou pela renovação do sistema educacional, "tornam-se objetos de 
declarações claras e circunstanciadas" (CHERVEL, 1992, p. 191). De outra maneira, a disciplina e sua finalidade permanecem ocultas e no cerne da naturalização do conhecimento.

Nesse sentido, assume-se que as disciplinas não são uma expressão direta do conhecimento científico e, sim, construções e tradições que se consolidaram ao longo do tempo até se naturalizarem.

Segundo Fourquin, esse processo faz com que o conteúdo a ser ensinado na escola pareça natural, ou seja, ocorra a naturalização do que deve ser ensinado:

\begin{abstract}
Sabe-se que por um efeito de desconhecimento estrutural próprio de todo o empreendimento de transmissão simbólica, aquilo que pode haver de contingente, de arbitrário, de "socialmente construído" ou ideologicamente enviesado nos conteúdos de ensino, está destinado o mais das vezes a permanecer despercebido; a naturalização da coisa ensinada estando no coração da legitimação profissional do docente. (Fourquin, 1992, p.43)
\end{abstract}

Nesse processo, Fourquin identifica o que denomina de "imperativos funcionais específicos", que são definidos pelos conflitos de interesse e pelas disputas relacionadas às fronteiras das disciplinas escolares. Para além desses, o autor ainda sinaliza a presença de fatores decorrentes de uma necessidade funcional de didatização dos saberes que se inserem no interior da escola. São os "imperativos didáticos", como, por exemplo, as técnicas de condensação ou o lugar concedido às questões e aos exercícios. Essas "marcas" pelas quais se reconhece um saber escolar também operam nos processos de seleção.

Diante desse panorama, abre-se espaço para reconhecer que no saber escolar coexistem outros processos e ingredientes, e que a área acadêmica não é a única referência em sua definição. Garcia (1998), por exemplo, problematiza a relação da escola com saberes de natureza não acadêmica, como os saberes cotidianos dos alunos.

Esse autor assume que além do conhecimento escolar ter suas próprias características epistemológicas, ele integra as contribuições de muitas distintas formas de conhecimento, e não só do conhecimento científico.

Ao argumentar em prol de uma escola que atue na formação de cidadãos capazes de abordar os problemas complexos de seu mundo, Garcia defende que é preciso deixar de considerar as disciplinas científicas 
como o único marco de referência da escola.

Embora esse projeto educativo não se reflita em toda a obra "Hacia uma teoria alternativa sobre los contenidos escolares", há a defesa de que a necessidade a ser atendida pela escola é a do enriquecimento do conhecimento cotidiano, capacitando as pessoas para gerir da melhor forma a vida em seu entorno. Há também, explicitamente, um alinhamento com a perspectiva crítica.

Nesse sentido, o autor critica abordagens que exacerbam a dicotomia conhecimento cotidiano $x$ conhecimento científico, $\mathrm{e}$ desqualifica tanto as teorias que supõem que possa haver a substituição de um por outro, quanto as que defendem que há uma coexistência absolutamente independente.

Como sistematiza Garcia (1998), ambas as tendências dicotômicas tendem a exacerbar as diferenças entre o conhecimento científico e cotidiano, como se o primeiro fosse abstrato, universal, fortemente organizado, com definição precisa e clara dos conceitos, explícito, complexo; e que o segundo se trate de um saber ligado ao concreto, pouco organizado, pouco preciso, implícito e simples.

Garcia (1998) argumenta, ainda, que essa visão dicotômica parece estar muito centrada em uma visão reducionista, tanto do que seja o conhecimento científico quanto do que seja o conhecimento cotidiano.

O conhecimento cotidiano é, muitas vezes, entendido como o saber envolvido na tomada de decisões primitivas, utilizado para resolver problemas simples. Garcia (1998), por outro lado, propõe uma visão ampliada, considerando que o conhecimento cotidiano "é o que as pessoas utilizam para se mover em um mundo incerto, que muda continuamente, resolvendo problemas abertos (de relações interpessoais, ambientais, etc.)" (p. 41).

Não haveria, assim, a necessidade de se contrapor o conhecimento científico ao conhecimento cotidiano, ou conhecimento banalizado. Nesse sentido, o conhecimento científico deveria contribuir para uma forma crítica de atuar, ou seja, para que o conhecimento do sujeito sobre o mundo possa adquirir um potencial transformador.

Como já apresentamos anteriormente, as teorias críticas do currículo aparecem em cena para denunciar justamente as finalidades 
implícitas dos ditos "saberes academicamente respeitáveis".

Principalmente no que concerne ao período anterior ao surgimento das tendências críticas do currículo, muitos autores tomariam como dada ou óbvia a subvenção da seleção dos saberes "matéria prima" do currículo às áreas acadêmicas de prestígio. Isso significa entender que a definição do que deve ser ensinado na escola deve provir de uma escolha dentre os saberes acadêmicos das áreas "mais importantes" do conhecimento. Desse ponto de vista, a seleção dos saberes constitutivos do currículo opera, principalmente, segundo uma lógica da epistemologia, ou seja, da própria organização do conhecimento acumulado pela humanidade e presente na academia.

Esse ponto de vista pode ser bem exemplificado na concepção de currículo defendida por Bruner (1987), na qual o conhecimento escolar não passa de uma espécie de "vulgarização" do conhecimento científico. Entretanto, como vimos, para outros autores, já sob a influência dos estudos críticos do currículo, as disciplinas de ensino são irredutíveis a essas características historiográficas tradicionais (CHERVEL, 1992).

Assim, é preciso reconhecer que os saberes escolares são constituídos em processos complexos, que envolvem disputas por recursos, visões de mundo, condicionantes sociais e a própria afirmação profissional dos sujeitos envolvidos, além de imperativos didáticos.

\subsection{Disciplinas Escolares de Saberes Científicos}

Para avançar nessa discussão, vamos nos debruçar mais especificamente sobre o papel dos "saberes de referência" ou dos conhecimentos das "áreas acadêmicas" nos processos de seleção cultural que ocorrem, de forma mais ou menos explícita, no interior do currículo.

$E$ dentre os saberes presentes na cultura escolar, os saberes das chamadas ciências naturais, como a Física e a Química, apresentam ainda suas particularidades. A despeito de serem, em geral, disciplinas consolidadas, é preciso problematizar o status que elas parecem ter perante outros saberes, bem como a relação desse status com critérios pedagógicos e epistemológicos.

Para Lopes (1999). as disciplinas escolares de ciências físicas 
sofrem maior influência de fatores ligados à ciência de referência, aos critérios epistemológicos, e à organização de sociedades científicas, do que de fatores externos, como a estrutura política, social-econômica ou critérios sociológicos, na medida em que se trata de um saber historicamente mais consolidado: "Não é à toa que a sociedade questiona e exige argumentos à introdução de Filosofia, Sociologia ou Ecologia no currículo, enquanto encara como natural a permanência da Química, solidamente estruturada" (LOPES, 1999, p. 182).

Para Young (apud LOPES, 1999), os conhecimentos de maior status são aqueles que podem ser formalmente avaliados, ensinados às crianças mais capazes, em turmas homogêneas e que apresentam bom rendimento. $E$ isso apresenta forte relação com o prestígio de certas áreas acadêmicas e suas formas mais rígidas:

Esta é também a razão pela qual é nos setores de mais prestígio do sistema educativo, naqueles para onde vão os melhores alunos e onde se transmitem os saberes dotados de mais forte legitimidade acadêmica, que as resistências às inovações são mais fortes. (YOUNG apud FOURQUIN, 1993, p.93)

Nesse sentido, destacamos a física como uma área de conhecimento extremamente paradigmática ${ }^{2}$, consolidada e, por isso, muitas vezes mais resistente a inovações e problematizações. Segundo Chauí: "Nessas condições pode-se compreender o prestígio da ciência e por que ela serve como critério da diferença entre a cultura dominante e a dominada: a primeira se oferece como saber em si e do real, e a segunda como não-saber" (CHAUÍ, apud LOPES, 1999, p.78).

Discutindo os limites da tendência crítica e do movimento de desmistificação dos conteúdos e programas, Fourquin (1992) argumenta contundentemente sobre a diferença entre questionar as condições sociais da produção e difusão dos conhecimentos e questionar os critérios epistemológicos de sua validade. Embora uma discussão curricular, em geral, possa problematizar a forma como os saberes são validados no interior do contexto escolar e, por vezes, questionar de forma crítica os processos pelos quais essa validação ocorre, isso não implica necessariamente fazer um julgamento epistemológico.

No entanto, ao pensar especificamente a disciplina de física,

\footnotetext{
${ }^{2}$ No sentido kuhniano.
} 
seus status e as maneiras pelas quais seus saberes se organizam, reconhecemos, assim como Lopes (1999) e Apple (2006), uma relação intrínseca desse processo com a epistemologia desse conhecimento.

$E$ isso se reconhece porque a escola legitima certa visão de ciência. Chevallard (1998), que é um dos principais responsáveis pelo cunho do termo transposição didática, reconhece explicitamente algumas das características específicas do conhecimento escolar que podemos relacionar com a "visão de ciência" veiculada pela escola.

Na obra "La Transposición Didáctica”, Chevallard (1998) define que para que um saber seja escolarizável, uma vez que nem todos os saberes o são, ele deve ser extirpado de seu contexto de origem de modo a se desvincular da época específica em que foi produzido e das pessoas relacionadas à sua "descoberta", para se tornar um saber impessoal e dessincretizado (CHEVALLARD, 1998). Entendemos que esse tipo de requisito, que na compreensão de Fourquin corresponde ao um tipo de "imperativo didático", corrobora para a construção de certa imagem de ciência.

Apple (2006) reafirma que esse tipo de "abordagem negativa", bastante irreal, geralmente associada à objetividade e ausência de conflitos, é endêmica a muitas áreas e especialmente às ciências. No entanto, ao discutir aspectos ocultos dos currículos, ele evidencia que essa visão de ciência apresentada na escola é essencialmente o arquétipo de uma posição ideológica.

Para ele, o que é ensinado nas escolas é a "lógica reconstruída" (o que dizem que os cientistas fazem) e não a "lógica utilizada" pelos cientistas (o que cientistas parecem de fato fazer). Nesse sentido, os domínios científicos são apresentados na escola como:

corpos de conhecimento, na melhor hipótese organizados em torno
de regularidades, como nos currículos de muitas disciplinas e
voltados a investigação (...) e na pior das hipóteses, como dados
bastante isolados que alguém deve dominar para fazer testes" Quase
nunca são examinados seriamente como uma construção pessoal de
seres humanos (Apple, 2006, p.131).

Essa imagem de ciência implementada nas escolas aproximase muito da visão empírico indutivista, que tende a afirmar que o conhecimento científico se fundamenta em uma base empírica, e obtém verdades inquestionáveis dos fatos, da realidade, por meio da experiência. 
Para Apple (2006), o conhecimento científico como vem sendo ensinado nas escolas, leva a um quadro onde os alunos são:

\begin{abstract}
"forçados", por causa da própria ausência de um quadro realista de como as comunidades científicas repartem o poder e os recursos econômicos, a internalizar uma visão que tem pouco potencial para questionar a legitimidade dos pressupostos tácitos do conflito interpessoal que governam suas vidas e sua própria situação educacional, econômica e política. (...) Quando essa situação se generaliza como a perspectiva básica pela qual devemos nos relacionar aos paradigmas econômicos e políticos de uma sociedade, não é difícil ver como pode servir (...) para justificar essa conjuntura estrutural por meio de regras constitutivas de um pensamento que façam qualquer outra perspectiva sobre o conhecimento parecer artificial. (Apple, 2006, p.135)
\end{abstract}

Nesse sentido é que reconhecemos a existência de um vínculo entre a ideia de ciência vinculada na escola, que é fundada sobre uma racionalidade irrefutável, e a naturalização do conhecimento corporificado no currículo, que é tratado muitas vezes como única possibilidade válida.

Muito do que compõe essa visão empírico-indutivista de ciência tem origem no chamado "método científico tradicional", formalizado por Francis Bacon. Conhecido também como método indutivo, essa abordagem se resume numa seqüência de passos que se deve percorrer em busca do conhecimento verdadeiro. O método científico consistiria, então, em fazer observações e experimentos, acumular dados, fazer hipóteses gerais e verificar tais hipóteses por meio de mais experimentos. Esse critério é encarado como fonte de demarcação entre ciência e não ciência, sendo o experimento a prova cabal da verdade, uma vez que é encarado como expressão da natureza. O conhecimento assim produzido teria um caráter neutro, independente do observador ou de valores subjetivos.

A busca de um método prescritivo que garanta a cientificidade e o caráter de verdade dos conhecimentos científicos foi, também, o que almejou Karl Popper, na proposição de seu "método hipotético dedutivo". Constituído de uma crítica ao método indutivo tradicional, ele argumenta em prol de um critério de conjectura e refutação do conhecimento. Nesse sentido, ele confere maior importância à criação das hipóteses e se distancia do empirismo-lógico, mas sem abdicar da fronteira de demarcação entre ciência e não ciência (ZANETIC, 1996).

Thomas S. Kuhn diferentemente de Bacon e Popper, traz uma 
teoria que não é prescritiva, ou seja, que não pretende dizer como deveria ser a ciência. Como historiador da ciência e filósofo, apresenta uma abordagem de caráter mais descritivo. Usando a história da ciência como elemento estruturador de sua epistemologia, sua proposta é bastante controversa e inovadora, desconstruindo a neutralidade da ciência e seu caráter evolutivo e linear.

Para Kuhn, a ciência passa por momentos de ruptura que são verdadeiras revoluções científicas, no qual os dogmas, sempre componentes de um certo paradigma, são postos à prova. $\mathrm{O}$ conceito de paradigma $^{3}$ é central em sua obra e poderia ser descrito como um conjunto de realizações que são aceitas como verdade e fornecem os caminhos possíveis de determinada área de pesquisa. A mecânica clássica seria um exemplo de paradigma (KUHN, 2005).

Os períodos de estabilidade da atividade científica são chamados de ciência normal. Durante esses períodos, o cientista trabalha numa espécie de quebra-cabeças, tentando encaixar peças para obter uma figura prevista pelo paradigma dominante. É o paradigma dominante que irá ditar quais são os problemas válidos, ou seja, o que é científico e o que não é, e quais são as soluções aceitáveis. O encontro de um resultado experimental discrepante é, nesse momento, considerado erro do cientista, nunca da teoria (lbidem).

Da atividade científica "normal" surgem as crises, que irão dar início às revoluções científicas, nas quais há uma reestruturação de um campo de pesquisa, e na qual mudam as "verdades" referentes a conceitos, métodos técnicas e interpretações. Isso irá constituir um novo paradigma dominante (Ibidem).

A visão de ciência introduzida pela obra de Thomas Kuhn é uma negação da neutralidade da ciência, mostrando que ela está submetida a dogmas e tradições. Não é o experimento que detêm o papel de verificação e que determina a verdade da ciência, mas sim o paradigma dominante.

A negação de um método científico único e a explicitação da

\footnotetext{
${ }^{3} \mathrm{O}$ conceito de paradigma presente na obra de Kuhn é considerado bastante controverso. Esse conceito apesar de central adquire diferentes sentidos e é alvo de muitas críticas. Para a reflexão que pretendemos, no entanto, a definição ora apresentada nos parece adequada.
} 
atividade científica como uma atividade humana complexa, não neutra e diversificada, está presente em vários outros epistemólogos, como Paul Feyrabend (1977) em seu "anarquismo epistemológico", ou no "novo espírito científico" de Bachelard (1977), ou ainda na visão antropológica de Bruno Latour (2001).

Ainda que sem adentrar o debate trazido por esses autores, fica claro que não existe um consenso filosófico que nos permita definir uma única concepção sobre a natureza do conhecimento científico. Ainda assim, podemos afirmar que o debate atual encontra-se muito distante do empirismo ingênuo, e que não é possível defender, de forma séria, do ponto de vista filosófico, a existência de um método único, universal e que assegure critérios de verdade acerca do que é ciência e não ciência. Nesse sentido, assim como Zanetic, consideramos que já não se pode aceitar a definição ingênua e positivista do método científico tradicional (ZANETIC, 1989).

No entanto, o impacto desses debates parece estar um tanto restrito ao campo filosófico. Isso porque, de maneira geral, o discurso oficial da ciência e do cientista, tanto no que se refere ao ensino formal (em todos os níveis) quanto no que concerne a muitas formas de divulgação científica, ainda se aproximam muito dos preceitos ingênuos do positivismo e do método científico.

E nesses alicerces se fundamenta uma forma de poder inequívoco, do qual a ciência se beneficia (LOPES, 1999), mantendo uma tradição e um prestígio acadêmico inquestionável, e também um espaço garantido e privilegiado dentre os saberes selecionados pela escola.

\subsection{Saberes de Física e Formação de Professores}

É a partir do panorama desenhado nesse capítulo que pretendemos adentrar a problemática da formação de professores de física.

Dessa forma, podemos compreender que a reflexão inerente à temática do currículo envolve uma grande diversidade de aspectos. No entanto, de uma maneira geral, o currículo se estabelece em íntima relação com algum saber, que é expropriado de um contexto e repensado em outro, com alguma finalidade ou por algum motivo.

Nossa perspectiva é, então, a de problematizar especialmente 
- saber de referência (mais especificamente o saber da física), suas contribuições para educação básica e, consequentemente, seu papel na formação de professores. Nesse sentido, para questionar mais a fundo o status do saber científico e sua relevância e tratamento, nos serão úteis também alguns elementos das chamadas teorias críticas do currículo.

Pretendemos estabelecer uma maneira de olhar para o currículo que possa desvelar características profundamente naturalizadas.

Isso significa, primeiramente, encarar as disciplinas como construções sociais e não como expressões diretas do conhecimento em si. Essa abordagem nos permitirá buscar uma compreensão histórica inclusive da forma pela qual a formação de professores se estabeleceu por áreas do conhecimento.

Olhar para o currículo de uma forma mais crítica também se revelou uma ferramenta interessante para tentar compreender a formação nas licenciaturas numa perspectiva mais ampla. Nesse sentido, buscaremos identificar os espaços e formas ocupados por saberes de naturezas distintas presentes nos currículos das licenciaturas e como surge a tensão na relação entre esses saberes, em diferentes âmbitos. Buscaremos identificar como se justifica a existência desses saberes nos currículos da licenciatura, quais são as referências e origens desses conhecimentos e os mecanismos pelos quais eles se sustentam.

Assumindo ainda a não neutralidade das configurações curriculares, pretendemos olhar especialmente a questão das finalidades educativas implícitas e explícitas que subjazem a tal ou qual proposta curricular.

Como tentamos mostrar ao longo desse capítulo, o saber acadêmico e os especialistas terão diferentes papéis se assumirmos diferentes concepções de educação e diferentes finalidades educativas. Cabe então refletir como esse processo é mediado pela formação inicial de professores e qual o papel que o conhecimento físico assume nesse processo. 


\title{
CAPÍTULO 2
}

\section{Saberes e Saberes para Formar Professores}

\author{
"É tarefa daqueles que pouco sabem - por isso sabem \\ que sabem algo e podem assim chegar a saber mais - \\ em diálogo com aqueles que, quase sempre, pensam \\ que nada sabem, para que estes, transformando seu \\ pensar que nada sabem em saber que pouco sabem, \\ possam igualmente saber mais."
}

Paulo Freire

Antes de adentrarmos aos problemas da formação inicial de professores de física e às formas como ela vem se delineando em diferentes âmbitos (que vão dos mais gerais, como legislações e diretrizes, aos mais concretos, como os cursos de licenciatura e suas práticas), buscaremos construir ainda um outro aporte de natureza mais teórica.

Isso se mostrou indispensável à nossa empreitada, dirigida a investigar os saberes de física nos cursos de licenciatura, uma vez que existe uma ampla literatura voltada, especificamente, ao "saberes do professor", ou seja, aos saberes necessários para formar um professor. Não nos seria possível ter uma compreensão coerente dos âmbitos de pesquisa nos quais nos debruçaremos na sequência desse trabalho sem construir um quadro teórico que permitisse situar alguns elementos oriundos da área específica de "formação de professores". E isso porque esses conhecimentos se encontram imbricados de maneira muito intrínseca nas formas e discursos de alguns de nossos âmbitos de pesquisa, como se verá mais adiante.

A formação de professores tem estado presente dentre as questões emblemáticas da história recente da educação. Muito conhecimento tem se produzido sobre essa temática, nas últimas décadas, e essa produção, se dá na forma de um amplo espectro de objetivos e desenhos de pesquisa.

Ressaltamos que esse capítulo será construído no intuito de 
estar mais próximo do olhar específico da área de formação de professores. Embora alguns aportes já construídos, no capítulo anterior, pudessem abrir caminhos para refletir sobre questões aqui presentes, e que existam até autores em comum, evitamos fazer relações que não sejam típicas da área de formação de professores. Nesse sentido, destacamos nossa opção por manter uma abordagem que contemple formatos, marcos teóricos e autores amplamente reconhecidos na área de "formação de professores". Nesse sentido, pretendemos criar condições para vir a explorar, apenas mais adiante, as possíveis relações entre os aportes teóricos das questões de currículo e formação inicial.

André et al (1999), em um artigo intitulado "Estado da Arte da Formação de Professores no Brasil", propõem uma forma de organização das pesquisas realizadas em teses e dissertações, que tem sido utilizada, inclusive em pesquisas mais recentes dessa mesma natureza.

As pesquisas sobre formação de professores, segundo essa perspectiva, podem ser classificadas em "Formação Inicial", "Formação Continuada", e "Identidade e Profissionalização Docente".

Quanto à metodologia, o artigo menciona que há trabalhos que são estudos de caso (voltados a algum aspecto muito particular) e que outros são análise de depoimentos (visam conhecer opiniões, pontos de vista ou representações dos informantes). Há, ainda, os estudos teóricos, as pesquisas históricas, a pesquisa-ação e a análise das práticas pedagógicas.

As autoras apontam ainda que:

Estudos voltados ao conhecimento de realidades locais, baseadas
em opiniões de um grupo restrito de sujeitos, deixam abertas muitas
indagações sobre aspectos abrangentes da formação docente, como
por exemplo que processos e práticas de formação seriam mais
efetivos no contexto atual da educação brasileira e que políticas
deveriam ser formuladas para aperfeiçoar cada vez mais tais práticas
e processos (p. 304 )

Nesse sentido, situamos nossa pesquisa dentre os trabalhos que tem sua preocupação central na "Formação Inicial de Professores", e especificamente em Cursos de Licenciatura.

Nesse capítulo pretendemos nos debruçar sobre uma das questões centrais a todo projeto de formação docente: Os saberes docentes. Essa escolha reflete, em parte, a própria maneira como a formação inicial vem 
sendo problematizada em muitas pesquisas sobre "formação de professores".

Segundo Tardif (2010), a questão do conhecimento do professor, isto é, os saberes (saber fazer, competências, habilidades e etc) que servem de base ao trabalho dos professores no ambiente escolar, juntamente com algumas outras grandes interrogações, domina de uma maneira geral a literatura produzida nas ciências da educação norteamericanas e anglo-saxônicas e vêem penetrando com força no Brasil nas duas últimas décadas.

Ainda segundo esse autor, historicamente, essa questão está ligada à profissionalização do ensino e aos esforços feitos pelos pesquisadores no sentido de definir a natureza dos conhecimentos profissionais que servem de base ao magistério. Todavia, adverte que, com o passar do tempo, ela foi se estendendo e se ramificando, dando origem a produções teóricas relativamente autônomas (TARDIF, 2010).

No entanto, como adverte Contreras (2002), é preciso problematizar com cuidado expressões que passam a fazer parte dos slogans pedagógicos, pois muitas vezes elas escondem, atrás de um aparente consenso, formas de controle discursivo um tanto a-críticas. A solução, segundo ele, é trazer esses temas ao debate, "representando os diferentes significados que podem se esconder por trás da referência comum, dando-se conta das consequências de diferentes acepções, explicando suas projeções na prática profissional e nas políticas educativas" (CONTRERAS, 2002, p.24).

É nesse sentido que buscaremos tratar da temática dos saberes docentes, colocando esse elemento no centro da nossa análise, de maneira a vir a iluminar nossa busca por uma nova compreensão dos saberes de física nos currículos de formação de professores.

"Saberes" é uma expressão que pode ser polemizada, pois tem sido usada por alguns autores em detrimento, ou ao invés, da expressão "conhecimento".

Foucault (apud LOPES, 1999), por exemplo, denomina que "conhecimento" se refere àquelas considerações que podem ser validadas por meio de uma epistemologia, enquanto "saberes" envolvem todas as demais formulações. Segundo Lopes: 
O conhecimento; nesse caso, englobaria os saberes sistematizados, organizados com base em normas de verificação e coerência rigorosas. Trata-se tanto do conhecimento científico, quanto das disciplinas no campo das humanidades, dentro de uma esfera estritamente racional (LOPES, 1999, p. 94)

Para Lyotard (apud LOPES, 1999), o conhecimento se define pela determinação e aplicação de critérios de verdade, e o saber se estende às determinações e aplicações como eficiência, justiça, felicidade, beleza. "Pelo termo saber, o autor entende um conjunto de enunciados denotativos, ao qual se misturam as ideias de saber fazer, saber viver, saber escutar, constituindo um conjunto também de enunciados prescritivos, avaliativos, etc." (LOPES, 1999, p. 95).

Essa discussão tem ainda uma complexidade adicional ao pensarmos o contexto brasileiro, pois é recorrente em nossa literatura a apropriação tanto de autores da tradição francesa quanto de autores da tradição anglo-saxã. Os autores da tradição francesa, como Chevallard, Fourquin, Tardif, Perrenoud, fazem uso da expressão savoir, que é traduzida para o português como "saber". Já autores da tradição anglo-saxã, como Apple, Giroux, Shulman e Shön, usam a palavra knowledge, que é traduzida por "conhecimento".

Assim, os sentidos definidos por Foucault ou Lyotard, não poderiam se aplicar a todos a esses autores. Chevallard, por exemplo, utiliza a expressão "saber sábio" para se referir ao conhecimento científico.

No caso da reflexão aqui desenvolvida, faremos referências recorrentes a autores de ambas as tradições (francesa e anglo-saxã), e portanto, optamos por utilizar as palavras "saber" e "conhecimento" de forma indistinta em todo o texto.

Entrar no campo dos saberes docentes é mergulhar em um campo de múltiplos discursos e formas. Nesse sentido, é preciso esclarecer que não pretendemos aqui, fazer qualquer análise de tipologias de pesquisas ou propor qualquer tipo de classificação dos saberes docentes. Faltariam-nos elementos para isso.

Nosso intuito, ao contrário, é apenas trazer ao debate diferentes dimensões que o saber de física pode assumir enquanto um saber docente, quando trazemos à tona diferentes concepções sobre o que seja ser 
professor.

Nesse sentido, perpassaremos a literatura sobre formação de professores, em meio a uma amálgama de obras sobre os saberes docentes, ao mesmo tempo em que buscamos uma compreensão sobre os saberes de física enquanto um saber específico dentre os saberes do professor.

Para tanto construímos uma abordagem que se mostrou bastante apropriada, inclusive em etapas posteriores da pesquisa, que se caracteriza pela classificação dos saberes do professor em: "saber específico", e "saber pedagógico".

Assim primeiramente faremos uma caracterização preliminar no que concerne ao que chamaremos de saberes específicos e pedagógicos do professor.

Na seqüência, apresentaremos uma sistematização sobre a temática dos saberes docentes em diferentes concepções de professor, num percurso centrado nas grandes tendências da formação docente, sempre tentando situar a questão dos "Saberes Específicos" e dos "Saberes Pedagógicos" dentre os saberes do professor.

\subsection{Saberes Específicos e Saberes Pedagógicos - Caracterização preliminar}

Como já explicitado no capítulo anterior, entendemos que tanto a organização escolar como a organização dos cursos de formação de professores são resultado de um processo histórico, político e social. Nesse momento, buscamos um breve retrato, de como surge a tensão entre os saberes específicos e pedagógicos, e a forma como esses saberes estão consolidados em alguns âmbitos. Essa breve discussão pretende apenas situar esse problema, que faz parte da nossa questão de investigação. A busca da compreensão de como essa tensão se estabeleceu historicamente será explorada nos capítulos seguintes.

Os professores especialistas por disciplina ou área do conhecimento, formados em cursos de Licenciatura, são "professores de". São professores “de Física”, "de Química”, "de História” e etc.

Há, portanto claramente, um saber que é o objeto de ensino do professor, o conhecimento específico de uma dada área, os conhecimentos 
de Física, Química ou História. A esse saber que, é objeto de ensino do professor especialista, chamaremos "saber específico".

Se negarmos a visão de que ensinar é uma espécie de descoberta pessoal, possibilitada por um dom ou uma capacidade individual que se desenvolve naturalmente, diremos que não basta ao professor, que ele detenha os saberes que são objetos de ensino. Diremos que ele deve adquirir, também, saberes que fundamentem sua prática educativa. Diremos que ele se apropria de "saberes pedagógicos".

Essa questão, que está no cerne da própria profissionalização docente (TARDIF, 2010), tem estreita ligação com a existência da ideia de Licenciatura. Esses tipos de cursos fornecem uma licença a quem seja considerado apto a ensinar algum "saber específico", em algum contexto. Para isso, os cursos devem tratar, também, de saberes que fundamentem a prática educativa ou, "saberes pedagógicos".

Nesse sentido, demarcamos que o saber pedagógico é o que possibilita que alguém ensine algum saber específico.

Poder-se-ia argumentar, também, que existem saberes da área de educação de cunho mais teórico, que não têm uma conexão tão direta com a ideia de capacitar alguém a ensinar algo. Nesse caso, poderíamos falar em saberes específicos da área de educação, em diferenciação a saberes pedagógicos de preocupação mais prática, ligados ao saber-fazer da atividade docente.

No entanto, ressaltamos que, na presente análise, optamos por denominar "saber específico" somente os saberes que são objetos da ação de ensino (saberes de física, por exemplo). Os saberes educacionais, sejam eles mais teóricos, amplos, ou mais voltados à prática docente, serão denominados "saberes pedagógicos".

Para elucidar melhor essa questão podemos trazer, como exemplo, o retrato do que é tradicionalmente um curso de Licenciatura em Física:

Historicamente, a principal preocupação dos cursos de formação de professores era formar o professor em um conteúdo específico. Assim, cabia, por exemplo, aos Institutos de Física, formar o licenciando no conteúdo específico da Física em seu ciclo básico. Após essa formação específica, os futuros professores passavam a freqüentar disciplinas ditas pedagógicas, das Faculdades de 
Educação. Poucas disciplinas, chamadas de interface, compunham o currículo das licenciaturas, e, assim, cabia quase que exclusivamente ao licenciando a articulação entre os conhecimentos específicos disciplinar e pedagógico. (HIGA, 2005, p. 19)

Nesse cenário podemos delinear claramente a existência de dois saberes: os "saberes específicos" e os "saberes pedagógicos".

Há uma fragmentação e ela se apresenta muito claramente nas próprias estruturas dos cursos de licenciatura. O contato com o "saber específico", ou seja, a aprendizagem do conhecimento específico e a vivência desse processo, é de responsabilidade dos Institutos Específicos. E essas instituições podem não ter compromisso com o fato de estarem ensinando para futuros professores, ou seja, não têm preocupação quando às finalidades desse ensino. São frequentes, inclusive, a existência de ciclos básicos comuns de disciplinas, nos quais os conhecimentos específicos são ensinados de forma estanque, independente de qual uso se fará deles depois.

Por outro lado, as Faculdades, institutos ou departamentos de Educação, se ocupam do ensino dos conhecimentos pedagógicos produzidos pela aérea de educação, e os tratam de forma independente dos conteúdos que serão objeto de ensino.

As disciplinas de interface, ou seja, as "Práticas de Ensino", as "Metodologias" e as disciplinas de "Instrumentação", procuram, de alguma forma, priorizar a atuação de um profissional especializado no ensino de alguma área do conhecimento (HIGA, 2005), mas o fazem de forma ainda independente, tanto da aprendizagem proporcionada pelas disciplinas de conteúdo específico quanto pelas disciplinas pedagógicas.

Propomos-nos a investigar, então, na sequência desse capítulo, quais são os espaços e formas ocupados pelos "Saberes Específicos" e pelos "Saberes Pedagógicos", dentro da literatura que se debruça sobre a questão dos Saberes Docentes.

\subsection{Um percurso pelos Saberes sobre os Saberes Docentes}

Dado que, nas últimas décadas, os holofotes das pesquisas têm se direcionado para a questão dos saberes do professor (TARDIF 2010), há uma quantidade consideravelmente ampla de trabalhos sobre essa temática. 
Como nosso intuito é justamente o de desvelar o papel dos saberes (específicos e pedagógicos) nas diferentes concepções de professor presentes na literatura, escolhemos um percurso que privilegiasse exacerbar tendências.

Esse percurso é fortemente inspirado na obra de José Contreras: "Autonomia de Professores" (2002). Esse autor, visando discutir a questão da autonomia docente, perpassa vários paradigmas sobre o que significa ser professor. Nesse sentido ele destaca que, dependendo do que se entenda por "ser professor", em diferentes concepções de ensino e de educação, o significado da autonomia pode estar em lugares muito diferentes, ou assumir diferentes conotações. Entendendo que as grandes tendências exploradas por esse autor não são necessariamente excludentes, e que algumas podem sinalizar aspectos complementares a outras, procuraremos percorrer um caminho semelhante.

Fazendo uma analogia ao que Contreras (2002) afirma sobre a questão da autonomia docente, podemos afirmar que buscar um esclarecimento sobre os saberes docentes (específicos e pedagógicos) é, por sua vez, "a compreensão das formas ou dos efeitos políticos dos diferentes modos de conceber o docente, bem como as atribuições da sociedade na qual esses profissionais atuam" (CONTRERAS, 2002, p.25).

$E$ é nesse sentido que justificamos a nossa opção por analisar o problema dos saberes do professor frente a diferentes formas de entender 0 que significa ser docente.

Optamos então, assim como faz Contreras (2002), por discutir nossa questão de investigação, inicialmente, nas três principais tradições diferentes no que concerne a profissionalidade dos professores: a que entende os professores como técnicos (racionalidade técnica), a que defende o ensino como uma profissão de caráter reflexivo (saberes que sabem na prática) e a que adota para o professor o papel de intelectual crítico (saberes para ser intelectual e crítico).

Além dessas três concepções, criamos mais uma categoria (saberes que não se sabem somente na prática), para incluir autores que, a nosso ver, não se enquadram exatamente nas tendências delimitadas por Contreras (2002), mas ganham uma importância especial pelo tipo de 
articulação entre saberes, além de serem referências muito freqüentes na área de formação de professores.

Assim, como afirma Contreras, acreditamos que é justamente na discussão e na análise dos limites e possibilidades que essas tendências podem oferecer ao nosso problema sobre os saberes docentes, que reside a possibilidade de formular de uma maneira mais matizada e complexa seus significados.

\subsubsection{Saberes do professor segundo a concepção da Racionalidade Técnica}

Um panorama geral, trazido por Nunes (2001), afirma que a partir da década de 70, em contraposição à valorização quase que exclusiva dos conteúdos específicos dentre os saberes do professor, começa um movimento de valorização dos aspectos didáticos-metodológicos relacionados às práticas de ensino.

Esse movimento vem no bojo da profissionalização docente, que institucionaliza uma gama de saberes reconhecidos socialmente, com chancela acadêmica e científica, e que o professor deve possuir para legitimar seu fazer.

Isso só é possível porque passa a estar disponível uma ciência aplicada, que permitiu o desenvolvimento de procedimentos técnicos para a análise e diagnóstico dos problemas de ensino e para seu tratamento e solução (CONTRERAS, 2002).

Nessa concepção se reconhece que aquilo que os professores possuem como profissionais está relacionado com o domínio técnico demonstrado na solução de problemas, ou seja, com o conhecimento dos procedimentos adequados ao ensino e à sua aplicação inteligente (ibidem).

Segundo Contreras (2002):

Sua perícia técnica se encontra no conhecimento de metodologias de ensino, no domínio de procedimentos de gestão e funcionamento do grupo em sala de aula e no manejo de técnicas de avaliação da aprendizagem. Todos esses conhecimentos, embora possuam uma parcela referente às habilidades desenvolvidas na prática, encontram, não obstante, seu fundamento na bagagem de conhecimento pedagógico disponível (p.95).

Reconhecidamente todas essas técnicas são importantes para 
a formação de um profissional docente, mas é importante assinalar que há um dado momento histórico em que esses conhecimentos passaram a ser enfatizados e adquirir certa centralidade tanto na formação como na atividade do professor.

A tendência que reduz a atividade docente a essa aplicação de técnicas, validadas por conhecimentos científicos que controlam e prevêem os resultados do ensino, é denominada de racionalidade técnica. Trata-se de uma concepção na qual se considera que esses conhecimentos, mais ligados às técnicas e regras derivadas do conhecimento acadêmico, são suficientes para um bom ensino. Nesse caso, o professor é visto como um técnico, um especialista que aplica com responsabilidade, na sua prática cotidiana, as regras que derivam do conhecimento acadêmico.

Formar professores, segundo a concepção da racionalidade técnica, se aproxima de formar um técnico, que executará a tarefa de aplicar em aula um método e/ou uma técnica de ensino, geralmente elaborada por especialistas. Monteiro (2001), afirma que a racionalidade técnica:

... buscando a eficácia através do controle científico da prática
educacional, trabalha com a concepção de professor como um
instrumento de transmissão de saberes produzidos por outros. Assim,
o saber científico encontra(va) no professor um profissional habilitado
- com a sua competência técnica - para adequá-lo, ou diluí-lo,(ou
distorcê-lo, se ineficiente), para que seja (fosse) aprendido pelos
alunos que, assim educados, e disciplinados, "evoluiriam para uma
vida melhor". (Monteiro, 2001, p.122)

Nesse caso, sua autonomia, segundo Contreras, reside na escolha adequada das estratégias de ensino. Contreras (2002) acrescenta que, "assumir o modelo de racionalidade técnica como modelo de profissionalidade significa assumir uma concepção produtiva do ensino, isto é, entender o ensino e o currículo como atividades dirigidas para alcançar resultados ou produtos predeterminados" (p.96).

Nessa concepção podemos dizer que o "Saber Pedagógico" se resume, predominantemente, ao domínio de técnicas, regras e procedimentos, que são definidos pelos especialistas. Esses, por sua vez são os responsáveis pela construção da ciência que dará fundamento aos fazeres didáticos. Em outras palavras, serão os especialistas que irão elaborar soluções para os problemas de ensino por eles diagnosticados e analisados. 
Podemos perceber, ainda, que o "Saber Específico", nessa tendência, ocupa um lugar bem demarcado, pois ele é o objeto de muitas das ações didáticas. As ações didáticas se dão também sobre os conteúdos. Isso porque as técnicas são muitas vezes desenvolvidas especialmente para o ensino de tal ou qual conteúdo ou tipo de "saber específico". São precisamente elas que tornam um saber passível de ser ensinado.

$\mathrm{E}$ no que concerne à questão de pensar um saber específico que se torna de alguma forma "ensinável", podemos encontrar uma importante contribuição na obra de Chevallard (1998). Embora esse autor não tenha seu foco exatamente na questão do professor e dos saberes docentes, buscaremos, por meio da elucidação da questão dos saberes específicos e do seu ensino, resgatar alguns elementos que se refletem nos saberes do professor.

Segundo Brockington e Pietrocola (2005), na pedagogia tradicional o sistema didático é sempre pensado como um binário composto por dois atores: professores e alunos. Porém, para Chevallard, há a necessidade de inserir o conhecimento como mais um objeto desse sistema. Segundo os autores:

O saber, assim, torna-se um elemento essencial na relação tida anteriormente como exclusiva entre professor e alunos. Ao fazer isso, CHEVALLARD amplia as possibilidades de análises teóricas desta relação: a epistemologia passa a ser um instrumento poderoso das análises do sistema didático, agora constituído por uma base ternária (professor, aluno, saber)(p.392)

A transposição didática é proposta por Chevallard (1998) como elemento de mediação do processo pelo qual o saber escolar se estabelece em sua relação com o saber científico (saber sábio). Nas palavras de Brockinton e Pietrocola (2005), esse é o processo que permite "compreender melhor como a produção científica migra da comunidade acadêmica para a sala de aula" (p. 389). E isso porque, no caso da física, por exemplo, "a pesquisa em Física induz a um Ensino de Física que deva, a princípio, ser sua própria imagem e semelhança" (BROCKINTON E PIETROCOLA, 2005, p.390).

Na visão de Chevallard, os conteúdos que serão ensinados na escola básica devem provir do "Saber Sábio", ou seja, do saber acadêmicocientífico. E é do ponto de vista desse saber, que se opera a seleção dos 
conteúdos que serão designados como "saberes a ensinar". Segundo Chevallard (1998), essa seleção deve operar com o estabelecimento de uma boa distância do sistema escolar restrito (professor e aluno) e deve levar em conta o ponto de vista do saber acadêmico e da sociedade.

A transposição didática compreende, então, uma série de operações a que o saber sábio selecionado será submetido, até se transformar em objeto de ensino. A primeira parte do processo, na qual os objetos do saber são materializados em objetos a ensinar, é feita por um conjunto de especialistas e chegará ao professor por meio dos "textos do saber" (livro didático, manuais, apostilas e etc.). E é seguindo esses "textos do saber" que o professor atua para modificar os efeitos do ensino, transformando-o, de "saber a ensinar", em "saber ensinado", completando o processo de transposição didática.

O professor, nessa concepção, é o sujeito que irá ensinar os saberes escolares, pré selecionados e conduzidos a ele, por meio dos "textos do saber", já em forma de objetos de ensino.

A Transposição Didática reconhece a existência de uma espécie de epistemologia própria dos saberes escolares, ressaltando que esse saber não é o mesmo saber produzido pelas áreas científicas. Assim, fica explícito que, por meio de uma série de processos didáticos, esse saber se torna passível de ser ensinado.

É interessante ressaltar, ainda, que é a lógica interna do conhecimento científico (de física por exemplo) que influencia o "saber escolar", quando esse se torna obsoleto em relação àquele. Embora esse processo seja mediado pela noosfera (especialistas que vão criar condições de compatibilidade entre o saber sábio e o saber escolar e maturar soluções de ensino), é o saber sábio e o que ele tem a oferecer ao sistema escolar que é levado em consideração.

Segundo Brockinton e Pietrocola (2005), a transposição didática possibilita uma fundamentação teórica para uma prática pedagógica mais questionadora, pois ela seria uma ferramenta que permite ao professor se recapacitar, "tomar distância, interrogar as evidências, pôr em questão as ideias simples, desprender-se da familiaridade enganosa de seu objeto de estudo" (CHEVALLARD, 1991, p.16). 
Ainda assim, do nosso ponto de vista, a proposta de Chevallard corrobora o paradigma técnico-racionalista, pois a função do professor se traduz em muito, na aplicação e no uso de materiais, desenvolvidos pelos especialistas que elaboraram os "textos do saber", e que tornam o saber sábio passível de ensino por meio de processos didáticos.

Embora não possamos afirmar que o fazer do professor se reduza apenas à aplicação de técnicas, podemos colocar em evidência que a teoria de Chevallard enfatiza elementos muito mais procedimentais, e trata o processo como se ele independesse das práticas e dos contextos.

Um dos motivos pelos quais a concepção técnico-racionalista da formação de professores tenha sofrido profundas críticas (principalmente nos anos 90) repousa no fato de que as técnicas, metodologias e instrumentos produzidos, bem como os professores treinados para fazer uso de todo esse arsenal, ao se deparam com a realidade da escola, pouco conseguiam realizar em relação às expectativas previstas.

É possível acrescentar a essa crítica outras, como as citadas por Monteiro (2001):

... esta concepção tem sido questionada e criticada por aqueles que apontam a simplificação operada por este raciocínio que: nega a subjetividade do professor como agente no processo educativo; ignora o fato de que a atividade docente lida com, depende de e cria conhecimentos tácitos, pessoais e não sistemáticos que só podem ser adquiridos através do contato com a prática; ignora os estudos culturais e sociológicos que vêem o currículo como terreno de criação simbólica e cultural; e que ignora, também, todo o questionamento a que tem sido submetido o conhecimento científico nas últimas décadas. (Monteiro, 2001, p.122)

As críticas à racionalidade técnica geraram uma série de estudos e pesquisa. Essas pesquisas, que buscaram enfatizar a complexidade presente nas situações que envolvem o trabalho do professor, passaram a investigar o conhecimento tácito elaborado e mobilizado durante a ação, pelos professores.

\subsubsection{Saberes que se sabem na Prática}

Os anos 90 foram marcados pela busca de novos enfoques e paradigmas para compreensão da prática docente e dos saberes dos professores. Nesse período, destacaram-se novas abordagens de pesquisa 
que passaram a reconhecer o professor como sujeito de um saber e de um fazer, fazendo surgir a necessidade de se investigarem os saberes de referência dos professores sobre suas próprias ações e pensamentos.

Um autor muito marcante nesse movimento é Donald Schön. Como crítico da concepção profissional que se depreende a partir da racionalidade técnica, ele aponta algumas limitações contundentes desse modelo.

Segundo esse autor, existem, no cotidiano do professor, situações que "não se pode resolver mediante a utilização de técnicas derivadas da pesquisa aplicada" (SCHÖN, 1983. p.41). Desse ponto de vista, os professores precisam compreender as situações no contexto específico em que se apresentam, na sua singularidade, e tomar decisões que nem sempre refletem uma atuação que se dirige a um fim. Em algumas situações faz-se necessário manter aberta a interpretação a diferentes possibilidades e finalidades, além de encontrar respostas singulares e às vezes provisórias, para casos que não haviam sido previstos nem imaginados (CONTRERAS, 2002).

Nesse sentido surge uma nova forma de encarar os fazeres docentes, na medida em que se reconhece o enfrentamento de situações problemáticas nas quais conflui uma multidão de fatores. E nas quais não se pode apreciar de forma clara quaisquer categorias pré-estabelecidas de soluções ou tratamentos adequados. Em muitos casos, definir o problema é exatamente entender o contexto no qual ele ocorre, a complexidade dos fatores envolvidos e sua relação com finalidades e valores, sobre os quais nem sempre há consenso, ou ainda, que se apresentam na forma de dilemas, diante dos quais não é fácil optar (ibidem).

Tentando dar conta de como os professores enfrentam situações que não se resolvem por meio de repertórios técnicos, Schön desenvolve a concepção do profissional reflexivo, com base na observação das formas com que diferentes profissionais realizam seu trabalho. Em sua construção, ele distingue o que seria o "conhecimento na ação" e a "reflexão na ação" (SCHON, 1983).

Para Schön existem muitas situações nas quais 0 conhecimento não precede a ação, mas, sim, está na ação. Esses 
conhecimentos são compreensões das coisas ou competências que interiorizamos, de tal forma que seria difícil descrever o conhecimento que implicitamente revela essas ações. Nesse sentido, o conhecimento não se aplica à ação, mas está tacitamente personificado nela. Por isso, esse é um "conhecimento na ação" (CONTRERAS, 2002).

A reflexão na ação, habitual na vida cotidiana, adota também características próprias na prática profissional. Nas palavras de Schön:

Quando um fenômeno que [o profissional] enfrenta elude as categorias ordinárias do conhecimento-na-prática, apresentando-se como único ou instável, o profissional pode fazer emergir e criticar sua compreensão inicial do fenômeno, construir uma nova descrição e comprová-la mediante uma experimentação sobre o seu andamento. Por vezes, chegará a elaborar uma nova teoria do fenômeno ao articular um pressentimento que tinha sobre ele." (Schön, 1983, p.62)

Segundo Ludke (2001), o objeto de análise principal de Schön nunca foi propriamente o professor, mas suas sugestões corresponderam de tal forma à expectativa dos formadores de futuros professores, que alcançaram um sucesso dificilmente obtido por outras ideias no campo da educação.

Afirmação semelhante poderíamos fazer sobre a ideia do "professor-pesquisador". Ainda segundo Ludke (2001), essa questão tem recebido atenção crescente desde o trabalho pioneiro de L. Stenhouse. Para a autora, a questão foi posta em destaque pois:

... esse autor, numa bela metáfora, reivindicava para o professor a mesma situação do artista, que ensaia com seus diferentes materiais as melhores soluções para os problemas de criação. Assim também, segundo Stenhouse, o professor deveria experimentar em cada sala de aula, tal como num laboratório, as melhores maneiras de atingir seus alunos, no processo de ensino/aprendizagem (LUDKE, 2001, p.4).

Nesse sentido, para Stenhouse, o ensino é uma arte, visto que significa a expressão de certos valores e de determinada busca que se realiza na própria prática. É a análise e a crítica da própria prática, ao invés da especificação dos resultados, o elemento que permite melhorar a atuação dos professores e, por conseguinte, sua capacidade de criar situações regidas por valores e critérios educativos (CONTRERAS, 2002).

É enfatizada, também, por esse autor a questão das singularidades das situações educativas, pois cada classe, cada aluno, cada 
situação de ensino refletem características únicas e singulares. $E$ nesse sentido não é possível saber o que é ou que será uma situação de ensino até que ela se realize (ibidem).

Segundo Stenhouse, é essa concepção que faz com que a ideia de professor pesquisador tenha sentido. A atividade investigativa que propõe, consiste em uma "disposição para examinar com senso crítico e sistematicamente a própria atividade prática" (Stenhouse, apud Contreras, 2002).

Para Contreras (2002), é fácil encontrar muitas semelhanças entre a concepção dos profissionais reflexivos de Schön e a ideia do "professor como pesquisador" de Stenhouse. Ambos sustentam sua posição em relação aos professores ou profissionais como resistência aos modelos da racionalidade técnica.

Esse novo enfoque da pesquisa, como já citado, alcançou um enorme sucesso no campo da educação e resgatou o papel da prática na formação e na atuação docente. E será justamente esse papel da prática, em roupagens como a do "professor como pesquisador" e do "profissional reflexivo", no centro de todo o movimento que se propõe a pensar o professor e sua profissionalidade, que dará origem à tendência denominada também de "racionalidade prática".

A obra de Maurice Tardif também é um marco no movimento de valorização dos saberes da prática docente. $\mathrm{O}$ autor critica o conhecimento acadêmico produzido na área de educação e sua desarticulação com a prática dos professores. Nas palavras do autor:

Até agora, a formação para o magistério esteve dominada, sobretudo pelos conhecimentos disciplinares, conhecimentos esses geralmente produzidos por uma redoma de vidro, sem nenhuma conexão com a ação profissional, devendo em seguida, serem aplicados na prática por meio de estágios ou de outras atividades do gênero. (Tardif, 2010, p.23)

Tardif tece profundas críticas à formação de professores e às pesquisas em educação que, do seu ponto de vista, não pesquisam de fato o conhecimento dos professores e não olham para eles e para suas práticas com a devida atenção. É no fazer dos professores, segundo ele, que se devem procurar muitas das respostas sobre a profissão docente, como a emblemática pergunta "Quais são os saberes que servem de base ao ofício do 
professor?" (TARDIF, 2010, p. 9).

A ênfase de seu programa de pesquisa no protagonismo docente fica bem clara na citação:

O saber não é uma coisa que flutua no espaço: o saber dos professores é o saber deles e está relacionado com a pessoa e a identidade deles, com a sua experiência de vida e com a sua história profissional, com as suas relações com os alunos em sala de aula e com os outros atores escolares na escola, etc (TARDIF, 2010, p. 11).

As conclusões sustentadas por Tardif se baseiam em um amplo programa de pesquisa que tem o foco voltado para os professores em suas práticas cotidianas, suas crenças, valores e etc.

Em suma, o autor resume sua tipologia dos saberes docentes em: saberes oriundos da formação profissional (saberes transmitidos pelas instituições de formação de professores), saberes disciplinares (sob a forma de disciplinas no interior das faculdades e de cursos distintos, transmitidos independentemente das faculdades de educação, os saberes das disciplinas emergem da tradição cultural e dos grupos sociais produtores de saberes), saberes curriculares (Programas curriculares que os professores devem aprender a aplicar), saberes experienciais (saberes baseados no seu trabalho cotidiano e no conhecimento de seu meio).

Para ele os saberes experienciais são saberes que nascem da prática e que constituem o núcleo vital do saber docente, aquilo que possibilita aos professores transformarem as relações de exterioridade com os outros saberes, em relações de interioridade com sua prática. Isso porque segundo ele, os professores não colocam todos os seus saberes em pé de igualdade. Quanto menos utilizável no trabalho é um saber, menos valor profissional ele deve ter. E, nessa ótica, os saberes oriundos da experiência de trabalho cotidiana parecem constituir 0 alicerce da prática e da competência profissional (TARDIF, 2010).

Outro ponto de destaque na obra desse autor reside exatamente na questão da temporalidade do saber dos professores:

O saber dos professores não é um conjunto de conteúdos cognitivos definidos de uma vez por todas, mas um processo em construção ao longo de uma carreira profissional na qual o professor aprende progressivamente a dominar seu ambiente de trabalho, ao mesmo tempo em que se insere nele e o interioriza por meio de regras de ação que se tornam parte integrante de sua consciência prática (TARDIF, 2010, p.14). 
Destacamos ainda outro trecho, no qual fica bastante evidente o alinhamento desse autor com as perspectiva da racionalidade prática e sua concepção sobre os conhecimentos dos professores:

O saber é um constructo social produzido pela racionalidade concreta dos atores, por suas deliberações, racionalizações e motivações que constituem a fonte de seus julgamentos, escolhas e decisões (TARDIF, 2010, p. 223).

Retomando nosso problema de pesquisa e ao que nos propomos também nesse capítulo, podemos notar que em todo o paradigma da racionalidade prática há um status muito diferente do "Saber Pedagógico". Ele não pode ser reduzido a um conjunto de técnicas, métodos ou ideias a serem aprendidas previamente. $O$ "Saber Pedagógico" passa a se construir na prática, por meio da pesquisa, e da reflexão crítica do professor sobre a sua ação.

Em nossa visão, o valor principal desse paradigma consiste na articulação de elementos que possibilitam identificar as limitações da racionalidade técnica. E diante disso, a prática passa a ser vista como algo essencial à formação de professores.

A racionalidade prática vai além de reconhecer o papel da prática na profissionalidade docente. Ela coloca a prática no centro do processo de formação e a faz hegemônica dentre os saberes docentes.

Nesse sentido, ressaltamos o quanto as discussões e os conhecimentos produzidos no âmbito do primado da prática são independentes de outros tipos de saberes dos professores como os "saberes específicos". Há um distanciamento tão grande que já não importa, nas discussões desses contextos, se estamos falando de professores de Física, Química ou História.

Diante desse quadro de valorização dos saberes ligados à prática docente, alguns outros autores contrapõem a importância do papel de saberes de outras naturezas.

\subsubsection{Saberes que não se sabem somente na prática}

Diante de uma questão de tão grande complexidade, vários outros pensadores trazem contribuições que não se reduzem a esses dois 
perfis já discutidos. Aqui apresentaremos, no entanto, apenas a visão de dois autores que tecem, de alguma forma, críticas ao paradigma dos "saberes da prática". São eles, Philippe Perrenoud e Lee Shulman. Suas visões apresentam muito pouco em comum entre si, mas, em nossa análise, ambos têm elementos que vão além, tanto da racionalidade técnica quanto da racionalidade prática, especialmente no que diz respeito aos saberes específicos e docentes.

Uma crítica à visão que opõe os saberes da experiência aos saberes científicos ou acadêmicos está na obra de Philippe Perrenoud. Baseado na noção de complexidade como um "questionamento à nossa representação e nosso controle do mundo", ele oferece, segundo Monteiro (2001), um novo instrumental conceitual para a questão dos saberes do professor. Além disso, ele defende que apenas os saberes não dão conta de explicar a prática do professor em ação. Nas palavras do autor:

O debate intensifica-se quanto à natureza dos saberes profissionais:
saberes eruditos, aprendidos nas universidades e nas faculdades?
Ou saberes constituídos a partir da experiência? É importante
compreender melhor a articulação de diversos tipos de saberes em
uma prática profissional e não é inútil propor classificações dos
saberes. Antes, porém, detenhamo-nos no essencial: situar os
saberes, sejam eles quais forem, no conjunto das competências de
um profissional. Resisto decididamente à tentativa de ampliar a noção
do saber para abranger todos os recursos cognitivos que um
profissional mobiliza. Sem dúvida, esse imperialismo dos saberes
pode ser explicado pelo fato de que as universidades participam cada
vez mais da formação de profissionais. Ora, os acadêmicos sentem-
se mais à vontade no mundo dos saberes. A referência às
competências a aproxima perigosamente das escolas
profissionalizantes. Ao chamar de saberes ou conhecimentos todos
os recursos cognitivos de um profissional, realizamos um grande
esforço: formar profissionais sem, aparentemente, deixar de transmitir
saberes e, portanto sem colocar em risco a principal identidade da
universidade. (Perrenoud, 2001, p. 139)

Muitas vezes a noção de competência é criticada por seu suposto utilitarismo, vocação para os interesses do mercado e etc. Aqui, no entanto, estaremos nos reportando à noção de competência tal qual como definida por Perrenoud (1999), ou seja, de que competência é um saber mobilizado para uma ação. Nas palavras do autor: "a noção de competências remete a situações nas quais é preciso tomar decisões e resolver problemas" (PERRENOUD, 1999, p. 3). Nesse sentido, assumir a noção de competência como o eixo estruturador para uma organização curricular, por exemplo, não 
significa virar as costas aos saberes. Significa, sim, assumir uma mudança nas finalidades educativas.

O esforço de Perrenoud vai na direção de mostrar que as competências profissionais exigem muito mais do que saberes. Segundo Monteiro (2001)

Ele consegue discutir e relativizar o papel dos saberes, discutindo as várias facetas do problema tais como a relação entre saberes sábios e científicos, saberes científicos e saberes da experiência (mostrando que eles não são opostos, mas que o saber científico pesquisa e busca objetos na experiência). De acordo com ele, investigar e desenvolver as competências do professor não invalida ou nega o papel dos saberes. Muito pelo contrário, é preciso a aquisição de conhecimentos para serem mobilizados nas competências. $O$ processo não é automático. $O$ domínio dos saberes não garante a competência. (Monteiro, 2001, p. 134).

Para Perrenoud é a noção de competência que é central. Para ele, o saber se justifica na mobilização de uma competência. E para que seja possível construir competências são necessários saberes a mobilizar.

Nesse sentido, uma situação pedagógica, ou seja, de ensino, pode exigir uma competência que mobilize "saberes pedagógicos" e "saberes específicos", como os saberes de física.

Outro trabalho de grande relevância, e crítico da racionalidade prática, é a obra de Lee Shulman. Esse autor se destaca por dar ênfase aos conhecimentos dos professores sobre o conteúdo, que é uma área que, segundo ele, ficou negligenciada pelo paradigma do "saberes da prática". Para Shulman, o que falta nos programas anteriores à sua obra é um esclarecimento da compreensão cognitiva dos conteúdos das matérias ensinadas, e das relações entre estes conteúdos e o ensino propriamente dito (Shulman apud Borges, 2001).

Shulman afirma que a atual separação entre conteúdos de ensino e conteúdos pedagógicos "é um desenvolvimento recente na área da educação, e que tem levado docentes e pesquisadores a valorizar em seus trabalhos muito mais os aspectos de ordem psicológica e/ou metodológica, deixando de lado a relação orgânica com o conhecimento de referência e que é a fonte de exemplos, explicações e formas de lidar com os erros e mal entendidos dos alunos" (Shulman, apud Monteiro 2001 p.134).

A partir do desenvolvimento de um completo programa de 
pesquisa, ele identificou vários tipos de conhecimentos que os docentes possuem, e produziu uma vasta tipologia desses saberes.

Em um artigo mais recente (Shulman, 2005), ele afirma que se fosse organizar os conhecimentos do professor para ordenar o saberes, usaria os títulos: Conhecimento do Conteúdo; Conhecimento Didático Geral; Conhecimento do Currículo, Conhecimento Pedagógico do Conteúdo; Conhecimento dos alunos e suas características; Conhecimento dos contextos educativos; Conhecimentos dos objetivos, finalidades e os valores educativos, e seus fundamentos filosóficos e históricos.

O Conhecimento Pedagógico do Conteúdo (Pedagogical Content Knowledge), atualmente muito utilizado nas pesquisas em ensino de ciências (PCK), compreende os saberes do professor que vão além do conhecimento do conteúdo. São formas particulares de conhecimentos dos conteúdos que englobam os aspectos dos conteúdos que são mais apropriados para o seu ensino. Segundo Girotto e Fernandez (2009), o PCK trata do como ensinar, que contempla "as formas de representações sobre o conteúdo e quais podem ser utilizadas, as exemplificações e analogias, as metodologias que podem ou não favorecer o aprendizado significativo deste ou daquele conteúdo, considerando os diversos ambientes educacionais" (p. 2). Aqui identificamos elementos do campo da didática específica, valorizando também o papel do fazer docente na construção desses saberes.

Outro saber que ganha especial atenção de Shulman é o que, na classificação acima, é denominado "conhecimento do conteúdo". Para ele, o conhecimento do conteúdo não se reduz a uma visão simplificada de saber a matéria. Existem diferentes dimensões que estão contidas no conhecimento do conteúdo, e essa proposição conduz a uma nova tipologia. O conhecimento do conteúdo possui então, quatro dimensões: o conhecimento do conteúdo em si, o conhecimento substantivo, o conhecimento sintático e as crenças a cerca do conteúdo.

No artigo de Grossman et al (2005), (do qual Shulman é um dos autores), é muito enfatizada a importância de que os cursos de formação de professores contemplem o conhecimento específico das disciplinas em todas as suas dimensões. Para eles, o conhecimento do conteúdo em si, que é na maioria das vezes entendido como sinônimo de deter o conhecimento do 
conteúdo é insuficiente. Apresentando vários casos exemplares de professores novatos que foram pesquisados, os autores concluem que, no trabalho do professor, é necessário também ter o conhecimento substantivo e o conhecimento semântico do conteúdo.

Os saberes do conteúdo em si são compostos de informação objetiva, organização de princípios e conceitos gerais (Grossman at al, 2005, p.11). O conhecimento substantivo é composto pelo conhecimento das estruturas de uma dada área de conhecimento. Essas estruturas são compostas pelos marcos exploratórios e pelo paradigma que é usado para guiar a investigação na área. O conhecimento semântico é o conhecimento das regras de uma dada área de conhecimento. É essa compreensão que permite distinguir o que está dentro e o que está fora dela. Além disso, existe a dimensão do conhecimento acerca das crenças sobre o conteúdo, segundo se argumenta que o professor deve ter consciência de suas crenças sobre o conteúdo, pois isso influencia o seu ensino.

Para esses autores, o professor precisa deter o conhecimento do conteúdo nesse sentido mais amplo, que contemple as quatro dimensões. É isso que vai permitir ao professor remodelar o conhecimento do conteúdo quando se prepara para ensinar. É ainda enfatizado que, nem os departamentos específicos nem os departamentos de educação têm conseguido dar conta dessa formação (Grossman et al, 2005).

Da complexa tipologia de conhecimentos que Shulman nos apresenta, podemos interpretar que ele define o que poderíamos chamar de subtipos, tanto do "Saber Específico" quanto do "Saber Pedagógico".

O conhecimento do conteúdo, entendido em um sentido mais amplo e completo, seria a sua maneira mais completa de falar sobre o "Saber Específico". Os saberes sobre valores, currículo, os alunos, a escola e etc. poderiam ser enquadrados em "Saberes Pedagógicos”.

Já o "conhecimento pedagógico do conteúdo" seria uma amálgama do "Saber Específico" e do "Saber Pedagógico". E isso porque a prática pedagógica, nessa visão, se baliza frequentemente por saberes que não são independentes dos conteúdos ensinados e, ao contrário, tem uma relação orgânica com eles.

Assim, podemos imaginar uma situação onde uma ação 
didática ou pedagógica só será bem sucedida se o professor tiver na sua bagagem um saber que o permita usar uma analogia adequada a uma dada situação e a um dado conteúdo específico. Como por exemplo, falar de um jogo de cartas fazendo numa analogia estatística visando um trabalho didático envolvendo a segunda lei da termodinâmica.

Esse tipo de conhecimento é amplamente dependente de uma forma de conhecer a prática do professor em seu contexto específico de ensino e também do conhecimento do que é objeto de ensino (a estatística e a segunda lei, por exemplo).

É interessante que os estudos de Shulman, apesar de resgatarem a importância do conteúdo a ser ensinado, centram suas atenções no professor e em suas práticas, diferentemente do que faz Chevalard, que centra sua análise nos próprios conteúdos.

No caso do "conhecimento pedagógico do conteúdo", fica evidente que se trata de um conhecimento do professor. O conhecimento do conteúdo é a fonte onde o professor vai buscar muitos dos elementos que precisa para lidar com as situações didáticas que surgem na práticas de sala de aula.

De nosso ponto de vista, entretanto, parece ainda, que o "conhecimento do conteúdo", mesmo entendido em sua dimensão mais ampla, ainda é condição prévia, para que o professor construa as outras dimensões. O cerne do que seja "saber a matéria" a ser ensinada (informação objetiva, organização de princípios e conceitos gerais) é um pré-requisito, embora seja sinalizado como insuficiente.

De todas essas tendências de pesquisas voltadas à sala de aula, debruçadas sobre os professores e seus conhecimentos mobilizados na prática, surgiu um conjunto de críticas que demarcariam uma nova tendência na área de formação de professores.

\subsubsection{Saberes para ser Intelectual e Crítico}

A perspectiva crítica pretende ir além da proposta reflexiva trazida pelo paradigma dos "saberes da prática", no sentido de ampliar os contextos estudados e as hipóteses formuladas, passando a levar em 
consideração o meio sócio- político e cultural no qual a escola se insere e as relações de poder aí implícitas.

Segundo a visão crítica, centrar as atenções no contexto de sala de aula, nas relações dos professores e seus saberes, e olhar apenas para dentro do contexto escolar e acadêmico pode não dar conta de responder a muitas demandas.

As limitações do professor reflexivo, por exemplo, parecem residir principalmente no fato de que a teoria de Schön centra-se mais nas práticas individuais. Da mesma maneira, a concepção do "professor pesquisador" é submetida à crítica semelhante, pois embora Stenhouse defenda a pesquisa como emancipadora, ele a reduz, ao explorar apenas os problemas pedagógicos da realidade docente. Assim, falta em sua obra, a compreensão do contexto social no qual se desenvolve a ação educativa (CONTRERAS, 2002).

Se o professor limitar seu universo de ação e reflexão à sala de aula, pode lhe faltar a compreensão de que estruturas externas a esse contexto o impedem, muitas vezes, de satisfazer a necessidade de seus alunos. Isso gera, então, uma insatisfação que pode conduzir o professor ao isolamento, culpando contextos mais imediatos como os alunos, os colegas ou a própria escola. (lbidem).

Como opção às abordagens centradas no mundo escolar, apresenta-se a concepção do professor como intelectual, sistematizada principalmente por Henry Giroux. Ele se baseia no trabalho de Gramsci para desenvolver sua abordagem, que assume o trabalho do professor como intelectual crítico, ocupado dos problemas e experiências da vida diária, a fim de construir cidadãos críticos e ativos (Giroux, 1997).

Para Giroux, as escolas devem ser lugares onde os alunos aprendem a lutar coletivamente por condições de liberdade individual e ganham capacidade para atuação social. E o professor tem um papel central nesse processo, como "intelectual transformador", que tem claro os referenciais políticos e morais sobre os quais exerce seu ensino. Nas palavras do autor:

Quando os professores não equacionam suas próprias concepções básicas a respeito do currículo e da pedagogia, eles fazem mais do que transmitir atitudes, normas e crenças sem questionamentos. Eles 
inconscientemente podem acabar endossando formas de desenvolvimento cognitivo que mais reforçam do que questionam as formas existentes de opressão institucional. (Giroux, 1997, p.48)

Assim passamos do status da importância da reflexão na ação, para a defesa de uma reflexão crítica. Segundo Contreras (2002):

... um processo de reflexão crítica permitiria aos professores avançarem para um processo de transformação da prática pedagógica, mediante sua própria transformação como intelectuais críticos, e isso requer, primeiramente, a tomada de consciência dos valores e significados ideológicos implícitos nas atuações de ensino e nas instituições que sustentam, e, em segundo lugar, uma ação transformadora dirigida a eliminar a irracionalidade e a injustiça existentes em tais instituições. Para isso, é necessário promover entre os professores um tipo de questionamento daquilo que tinham como certo, de modo que hoje se transforme em algo problemático, abrindo-se a novas perspectivas e dados da realidade. (Contreras, 2002, p. 165)

E ao falar do professor como intelectual crítico, comprometido com a mudança social, não podemos deixar de mencionar a obra do educador brasileiro Paulo Freire, embora ele não se atenha especificamente ao problema da formação de professores.

A dimensão da reflexão, que é trazida por Freire, é a da reflexão para transformação. É preciso alcançar a compreensão crítica de mundo, para mobilizar os saberes em sua transformação. Para Freire o saber reside na interação dialógica e problematizadora, "Saber que reflete o mundo e os homens, no mundo e com ele, explicando o mundo, mas sobretudo, tendo de justificar-se na sua transformação." (Freire, 1977, p. 55)

O desejo contido na concepção do professor como intelectual crítico pode ser expresso muito bem nas palavras de Apple:

... em primeiro lugar queria que os educadores, sobretudo aqueles que com interesse específico no que acontece dentro das salas de aula, examinassem criticamente as suas próprias ideias acerca dos efeitos da educação. Essas ideias têm a ver com algumas pressuposições muito profundamente arraigadas, mas frequentemente inconscientes, sobre a ciência, a natureza dos homens e das mulheres e a ética e política de nossas teorias e práticas pedagógicas cotidianas. (Apple, 1994, p.44)

Retomando nossa problemática de pesquisa, avançaremos analisando essa tendência no que concerne aos "Saberes Pedagógicos" do professor. São apontadas como limitadas as abordagens que ignoram a compreensão crítica do contexto mais amplo no qual a escola está inserida, e 
as relações aí implícitas.

Desse ponto de vista os saberes pedagógicos do professor devem incluir uma compreensão crítica do contexto sócio político cultural que envolve a escola. Os professores, além dos saberes já apontados pelas outras tendências, teriam que ter um saber crítico que os permita ver a finalidade da escola e da educação mediante uma perspectiva de reprodução ou de transformação da sociedade. Esse mesmo saber, da perspectiva crítica, deve ser capaz de estabelecer conexões entre o conhecimento veiculado pela escola, suas formas de organização, regras, e as injustiças da sociedade de classes.

Aqui, embora autores como Giroux, Contreras e Apple, não mencionem de forma clara o papel do "Saber específico", talvez se possa extrapolar compreensões a esse respeito, por meio da problematização justamente da finalidade da ação educativa.

Os estudos críticos têm um tom de denúncia acerca da própria instituição escola e das finalidades explícitas e implícitas envolvidas em suas práticas, valores e saberes. E o saber específico aparece de certa forma como uma herança cultural elitista. Seriam exatamente esses conhecimentos que permitiriam que certos grupos tivessem uma condição privilegiada nas formas sociais de divisão do trabalho.

A obra de Giroux chama os professores a agirem como intelectuais, ou seja, a trazerem à tona os fatores ocultos da organização social e a mobilizarem seus alunos para uma condição de transformação da realidade em que vivem. Interpretamos que há aí, sim, muito espaço para se questionar os saberes que são objetos de ensino do professor, mas não são feitas menções explícitas a esse saber.

Uma vez que o conhecimento específico é visto como um instrumento de dominação social seria difícil pensar em formas de transformação, protagonizadas pelas classes dominadas, nas quais não haja a presença do saber específico dentre os saberes do professor. Por outro lado, nenhum desses autores dá indicativos de como esses saberes específicos poderiam servir a um projeto de emancipação.

Já na obra de Freire, essa mesma questão aparece de forma mais explícita. A problematização do conhecimento que é objeto de ensino e, 
portanto, do saber específico do professor, não escapa a ter que se justificar na transformação da realidade.

$\mathrm{E}$ isso porque tanto para alunos quanto para professores o conhecimento (específico e/ou pedagógico) só tem valor se for possível reconstruí-lo como uma forma de diálogo inteligente com o mundo.

No sentido freireano, não faz sentido, por exemplo, falar em saber a língua portuguesa apenas. Tanto professores quando alunos têm que estabelecer esse conhecimento como forma de melhor compreender e transformar a realidade. A língua portuguesa já deve ser ensinada/aprendida na mesma medida em que se compreende o que significa deter esse conhecimento e em que ele pode ajudar a mudar o mundo. Assim, vemos saberes específicos pensados de forma indissociável do que seria o saber pedagógico do professor segundo a perspectiva crítica.

\subsection{Considerações sobre os saberes na formação}

Em cada um dos paradigmas visitados, os Saberes Específicos e Pedagógicos ocupam espaços e se relacionam de forma distinta.

$\mathrm{Na}$ racionalidade técnica, podemos afirmar que existe uma relação, uma vez que os saberes pedagógicos agem sobre os saberes específicos por meio de técnicas, métodos e regras, que o transformam e o tornam passível de ser ensinado.

No paradigma da racionalidade prática, pouco ou nada se fala sobre o que é conteúdo de ensino. Tardif, por exemplo, chega a mencionar que eles existem no repertório docente, mas não aprofunda a questão. Já os "Saberes Pedagógicos" são alvo de completas teorizações. As construções teóricas apontam para a importância dos saberes do professor que não se reduzem a repertórios técnicos, mas que são construídos em situações de improviso, criação e reinvenção da sua própria prática. Isso se dá mediante uma postura reflexiva, ativa, e de investigação crítica do docente sobre suas próprias ações. Todas essas teorias e contribuições se construíram a tal distância do saber que é objeto de ensino que elas parecem independer dele e, portanto, independer da especialidade do professor.

Autores que de alguma forma criticam o paradigma dos 
"saberes da prática" são Perrenoud e Shulman. Na obra de Perrenoud encontramos análises que podem se aplicar tanto aos "Saberes Específicos" quanto aos "Saberes Pedagógicos". Essas reflexões se centram na noção de competência, que são a finalidade para qual os saberes devem ser mobilizados. E uma competência didática em sala de aula, voltada a uma finalidade de ensino, pode mobilizar saberes específicos, pedagógicos ou ambos.

Shulman concebe vários conhecimentos que devem compor os "Saberes específicos", e outros vários conhecimentos que devem compor os "Saberes pedagógicos". Há ainda em sua obra o "Conhecimento Pedagógico do Conteúdo" que é uma amálgama de saberes específicos e pedagógicos. Esse último se justifica numa relação orgânica entre os saberes específicos e os saberes pedagógicos, pois o saber específico do professor acaba também por orientar a prática educativa.

Dentre os autores intelectuais críticos, Freire traz uma reflexão diferenciada no que concerne aos "Saberes específicos". Lemos em sua obra, que eles são tratados de forma indissociável do "Saber Pedagógico". A temática do "saber específico" não aparece de forma explícita nos outros autores críticos.

Quanto aos "Saberes Pedagógicos" os autores críticos sinalizam para a importância da compreensão crítica da escola, considerando seu contexto sócio político cultural. Enfatizam o compromisso social do professor e que seus saberes estejam a serviço de uma transformação social.

Essa análise se encontra sistematizada na Tabela 2.1, na qual estão organizadas considerações a cerca dos saberes, para cada uma das concepções docentes que perpassamos e para alguns autores.

Podemos perceber que os saberes específico e pedagógico e a relação entre eles, se apresenta de forma distinta nos paradigmas e autores visitados. De posse desse mapeamento poderemos ir adiante na análise dos âmbitos de pesquisa que delimitamos para essa investigação, sempre buscando identificar como esses discursos, advindos da área da formação de professores, repercutem, e como a questão dos saberes e seus significados vão sendo incorporados em diferentes contextos, desde o oficial governamental, passando pela pesquisa em ensino de ciências até a prática 
concreta dos cursos de licenciatura.

Por hora. podemos constatar que a área da formação de

professores tem atualmente, uma tendência a voltar seus olhares mais aos

saberes que compõe o repertório docente do ponto de vista das práticas pedagógicas e há pouco espaço para a discussão dos saberes que são objetos de ensino.

\begin{tabular}{|c|c|c|c|}
\hline $\begin{array}{l}\text { Concepções de } \\
\text { Professor }\end{array}$ & Saberes Específicos & Saberes Pedagógicos & $\begin{array}{l}\text { Relação entre os Saberes } \\
\text { Específicos e Pedagógicos }\end{array}$ \\
\hline $\begin{array}{l}\text { Racionalidade } \\
\text { Técnica }\end{array}$ & $\begin{array}{c}\text { São os saberes } \\
\text { científicos selecionados } \\
\text { para o ensino, para } \\
\text { atualizar os saberes } \\
\text { escolares. Serão } \\
\text { transformados em } \\
\text { objetos de ensino pelos } \\
\text { especialistas. }\end{array}$ & $\begin{array}{c}\text { Aspectos didático } \\
\text { metodológicos } \\
\text { relacionados as técnicas } \\
\text { de ensino }\end{array}$ & $\begin{array}{l}\text { As ações didáticas se dão } \\
\text { sobre os conteúdos para que } \\
\text { eles se tornem ensináveis }\end{array}$ \\
\hline $\begin{array}{l}\text { Racionalidade } \\
\text { Prática }\end{array}$ & $\begin{array}{l}\text { Não há menção aos } \\
\text { saberes específicos }\end{array}$ & $\begin{array}{l}\text { Saber que se constrói, na } \\
\text { reflexão sobre a ação, } \\
\text { numa postura investigativa } \\
\text { crítica sobre a própria } \\
\text { prática }\end{array}$ & $\begin{array}{c}\text { Há um distanciamento } \\
\text { tamanho entre as dimensões } \\
\text { que as considerações desse } \\
\text { primado parecem não } \\
\text { depender em nada da } \\
\text { natureza do saber específico }\end{array}$ \\
\hline Perrenoud & \multicolumn{2}{|c|}{$\begin{array}{l}\text { Os Saberes devem se mobilizar na ação de alguma } \\
\text { competência }\end{array}$} & São tratados indistintamente \\
\hline Shulman & $\begin{array}{c}\text { Conhecimento do } \\
\text { conteúdo = } \\
\text { conhecimento do } \\
\text { conteúdo em si + } \\
\text { dimensão substantiva + } \\
\text { dimensão sintática + } \\
\text { crenças acerca do } \\
\text { conteúdo }\end{array}$ & $\begin{array}{c}\text { Conhecimento didático } \\
\text { geral + Conhecimento do } \\
\text { currículo + Conhecimento } \\
\text { dos alunos e suas } \\
\text { características + } \\
\text { Conhecimento dos } \\
\text { contextos, objetivos, } \\
\text { finalidades e valores } \\
\text { educativos }\end{array}$ & $\begin{array}{l}\text { O Conhecimento } \\
\text { Pedagógico do Conteúdo } \\
\text { reconhece uma relação } \\
\text { intrínseca entre o } \\
\text { conhecimento específico e } \\
\text { suas formas de ensinar } \\
\text { (conhecimento pedagógico) }\end{array}$ \\
\hline
\end{tabular}

\begin{tabular}{|c|c|c|c|}
\hline $\begin{array}{c}\text { Intelectual } \\
\text { Critico }\end{array}$ & $\begin{array}{l}\text { São questionados e } \\
\text { teriam relação com a } \\
\text { divisão social do } \\
\text { trabalho, porém não fica } \\
\text { claro qual seria seu } \\
\text { lugar num projeto } \\
\text { emancipador }\end{array}$ & $\begin{array}{l}\text { Compreensão crítica do } \\
\text { contexto sócio político } \\
\text { cultural que envolve a } \\
\text { escola. Compromisso com } \\
\text { a transformação social. }\end{array}$ & $\begin{array}{c}\text { Não é feita a ponte dos } \\
\text { saberes pedagógicos e das } \\
\text { perspectivas críticas com os } \\
\text { saberes específicos }\end{array}$ \\
\hline Freire & $\begin{array}{r}\text { Ambos devem se just } \\
\text { realidade. O conhecim } \\
\text { reconstrução do próprio } \\
\text { em diálogo }\end{array}$ & $\begin{array}{l}\text { car na transformação da } \\
\text { nto terá valor se servir à } \\
\text { onhecimento pelos sujeitos } \\
\text { om o mundo. }\end{array}$ & $\begin{array}{l}\text { São dimensões } \\
\text { indissociáveis }\end{array}$ \\
\hline
\end{tabular}




\section{CAPÍTULO 3}

\section{Currículo e Formação de Professores no Brasil}

A duração é o progresso contínuo do passado que morde o futuro e vai inchando à medida que avança

Henri Bergson

Começar uma problematização referente à Licenciatura em Física nos exige uma compreensão dos processos e práticas envolvidos na consolidação dos significados inerentes a um curso dessa natureza.

Como já argumentamos, compõem o currículo de um curso de licenciatura tanto um corpo orientado, estruturado e selecionado de conhecimentos, como uma finalidade, algo que se pretenda com o processo.

Subjacente ao contexto pontual de cada curso, há de se reconhecer a importância das regulamentações nacionais, em forma de leis e diretrizes que, inseridas em um contexto histórico, revelam expectativas e tendências que recaem sobre a formação de professores. São esses movimentos mais amplos, que se consolidaram no que aqui chamaremos de "modelos de formação".

Diferentes momentos históricos, marcados por diferentes concepções, regimes políticos e objetivos educacionais, demarcaram alguns exemplos emblemáticos de modelos de formação de professores. Pretendendo situar nosso problema de análise e compreender melhor os fatores envolvidos, faremos um breve percurso histórico.

Esse olhar tem a intenção de nos situar a respeito da formação de professores no Brasil, na perspectiva de tentar compreender como os modelos de formação vigentes hoje, se estabeleceram. Entendemos que para compreender esses movimentos de mudança é de suma importância analisarmos, mesmo que sucintamente, as condições históricas que instituíram e consolidaram certos pressupostos na formação docente. 
Nessa etapa do trabalho pretendemos compreender principalmente, os meios e justificativas pelos quais o "modelo $3+1$ " se consolidou de forma expressiva nos seios dos cursos de formação.

Na sequência apresentaremos de forma breve uma apreciação sobre as "Diretrizes Nacionais Curriculares para os Cursos de Física".

Após esse percurso nos debruçaremos de forma mais detalhada e minuciosa sobre as novas "Diretrizes Curriculares Nacionais para formação de professores da educação Básica" de 2002. Esse documento, que, de fato, induziu a quase totalidade dos cursos de Licenciatura existentes no país a alguma reestruturação, é um dos elementos centrais para essa pesquisa.

O percurso de análise aqui exposto, principalmente acerca das Diretrizes atuais para a formação de professores, será traçado tendo como pano de fundo a procura por finalidades implícitas e explícitas. Essa busca está de certa forma, fundamentada pela reflexão trazida no capítulo um. Nessa etapa, incorporaremos ainda a noção da "recontextualização por hibridismo" (Ball apud Lopes, 2008).

Principalmente no que concerne às diretrizes atuais de formação de professores faremos ainda uma análise sobre o prisma dos saberes docentes, incorporando o aporte desenvolvido no capítulo dois sobre os "saberes específicos" e sobre os "saberes pedagógicos" presentes nos discursos oficiais.

\subsection{A consolidação do modelo $3+1$}

Os cursos de licenciatura detêm organizações curriculares, que demarcam e organizam saberes, e que são regidos por regulamentações externas. Não se restringindo ao contexto formal, os cursos em suas práticas produzem novos significados e saberes, reconstruindo e desconstruindo paradigmas.

Segundo Garcia e Garcia (2004) a expressão licenciatura está relacionada aos elementos da história que constituíram a profissão docente e que definiram a institucionalização dos processos de formação de professores, que foram sendo construídos, nos séculos $X I X$ e $X X$, paralelamente ao desenvolvimento dos sistemas nacionais de educação e ensino (GARCIA E 
GARCIA, 2004, p. 2).

A formação de professores para as séries iniciais do ensino básico (generalista) e para as séries finais (especialistas por área de conhecimento), não apresentam os mesmos formatos e percursos, embora em dados momentos históricos estejam ligados às mesmas reivindicações educacionais. Ambas as formações têm profundas raízes nas Escolas Normais, mas centraremos nossa análise no modelo para formação de professores para o ensino secundário (especialista por área de conhecimento).

A própria nomenclatura Escola Normal, sugere a legitimação social de um conjunto de "normas", ou seja, de técnicas específicas que caracterizam a profissão docente. A ideia de fornecer uma "licença" a quem detenha esse conjunto de "habilidades didáticas" é indício de uma legitimação social, da ideia de que esses saberes são essenciais a quem queira praticar o ensino. (GARCIA E GARCIA, 2004).

No início do século $X X$ as Escolas Normais, primeiras iniciativas que se fundavam num projeto de formação docente, foram sendo disseminadas lentamente, o que se explica pelo seu custo elevado, uma vez que demandavam professores especializados e edifícios próprios. Assim, esses cursos funcionavam em número insuficiente para formar todos os professores necessários (VICENTINI e LUGLI, 2009).

É também nos inícios do século $X X$ que aparece a preocupação com a formação de professores para 0 secundário (correspondendo aos atuais anos finais do ensino fundamental e ao ensino médio), em cursos regulares e específicos. A formação desse tipo de professor inicia-se com a criação de universidades. Até então esse trabalho era exercido por profissionais liberais ou autodidatas, mas há que considerar que o número de escolas secundárias era bem pequeno, assim como o número de alunos. Com o início da progressão da industrialização no país, nas primeiras décadas do século $X X$, a necessidade de maior escolarização começa a se colocar entre os trabalhadores e inicia-se uma pequena expansão no sistema de ensino. Para atender a essa expansão, mais professores passam a ser demandados. Então, nos anos 1930, a partir da formação de bacharéis, acrescenta-se um ano com disciplinas da área de educação para a obtenção da licenciatura, dirigida especificamente à 
formação de docentes para o ensino secundário (GATTI E BARRETO, 2009).

Segundo Saviani (2009), a questão pedagógica, de início ausente, mesmo nas Escolas Normais (centradas nos conteúdos específicos de ensino), vai penetrando lentamente até ocupar posição central nos ensaios de reformas da década de 1930. Anísio Teixeira no Rio de Janeiro e Fernando de Azevedo em São Paulo, ambos influenciados pelo movimento da Escola Nova inauguram uma nova fase, com o advento dos Institutos de Educação, concebidos como espaços de cultivo da educação, encarada não apenas como objeto do ensino, mas também da pesquisa (SAVIANI, 2009).

Os Institutos de Educação do Distrito Federal e de São Paulo foram elevados ao nível universitário, tornando-se a base dos estudos superiores de educação: o paulista foi incorporado à Universidade de São Paulo, fundada em 1934, e o carioca foi incorporado à Universidade do Distrito Federal, criada em 1935.

E foi sobre essa base que se organizaram os cursos de formação de professores para as escolas secundárias, generalizados para todo o país a partir do decreto-lei n. 1.190, de 4 de abril de 1939, que deu organização definitiva à Faculdade Nacional de Filosofia da Universidade do Brasil, sendo esta instituição considerada referência para as demais escolas de nível superior (SAVIANI, 2009).

Esse mesmo decreto n. 1.190/39 tratava da organização dos cursos de Bacharelado em Física e do curso Complementar de Didática. $\mathrm{O}$ artigo 11 tratava da organização dos cursos de bacharelado em física e determinava que tivessem três anos e a seriação de disciplinas de acordo com a tabela 3.1 (BRASIL 1939).

\begin{tabular}{ccc}
\hline $1^{a}$ Série & $2^{a}$ Série & 3ª Série \\
\hline 1. Análise matemática. & 1. Análise matemática. & 1. Análise superior. \\
2. Geometria analítica e & 2. Geometria descritiva e & 2. Física superior. \\
projetiva. & complementos de geometria. & 3. Física matemática. \\
3. Física geral e & 3. Mecânica racional. & 4. Física teórica. \\
experimental. & 4. Física geral e & \\
\hline
\end{tabular}

Tabela 3. 1 - organização do curso de bacharelado em física de acordo com decreto 1.190/1934

O artigo 20 desse mesmo decreto trata do curso 
complementar de didática que teria a duração de um ano e seria constituído dos tópicos:

1. Didática geral.

2. Didática especial.

3. Psicologia educacional.

4. Administração escolar.

5. Fundamentos biológicos da educação.

6. Fundamentos sociológicos da educação. (BRASIL, 1939)

Por fim o artigo 49 do decreto n. 1.190/34 determina que:

Ao bacharel, diplomado nos termos do artigo anterior, que concluir regularmente o curso de didática referido no art. 20 desta lei será conferido o diploma de licenciado no grupo de disciplinas que formarem o seu curso de bacharelado (BRASIL, 1939).

Isso estruturou um padrão para as escolas de formação de professores secundários que se convencionou chamar de "esquema $3+1$ ", ou seja, 3 anos de estudos específicos na área de especialidade (História, Física, Química etc), e mais um ano de curso complementar na seção de didática para obter a Licenciatura (VICENTINI e LUGLI, 2009).

É importante ressaltar que ao ser generalizado, "o modelo de formação de professores em nível superior perdeu sua referência de origem, cujo suporte eram as escolas experimentais às quais competia fornecer uma base de pesquisa que pretendia dar caráter científico aos processos formativos" (SAVIANI, 2009,p. 146).

Com a promulgação da primeira Lei de Diretrizes e Bases da Educação Nacional, Lei no 4.024, de 20 de dezembro de 1961, a formação profissional no Brasil, no que se refere à formação dos professores para o ensino secundário, ficou regulamentado que a mesma deveria ser feita em nível superior, nas Faculdades de Filosofia, Ciências e Letras. A Lei deixava a cargo do Conselho Federal de Educação a responsabilidade pela fixação de currículo mínimo e duração mínima dos cursos superiores que habilitam para o exercício profissional (ALVES, 2010).

Ainda em 1962, é publicado o Parecer do Conselho Federal de Educação ํo 292. Esse Parecer definiu as disciplinas pedagógicas que deveriam ser acrescidas à formação do bacharel para a formação dos professores do nível secundário, nos ciclos ginasial e colegial (Psicologia da Educação, Elementos de Administração Escolar, Didática e Prática de Ensino - esta última sob a forma de estágio supervisionado), devendo essas 
disciplinas constituírem, no mínimo, um oitavo da carga horária dos respectivos cursos, e estarem distribuídas ao longo de todos os anos, cuja duração total deveria ser de quatro anos. (ALVES, 2010).

Em 1966, por meio do Decreto-Lei no 53, as Faculdades de Filosofia, Ciências e Letras são fragmentadas e são criadas as Faculdades de Educação, com o objetivo de constituírem unidades destinadas à formação de professores para o ensino secundário e dos especialistas da Educação.

O Decreto de lei no 252 de 28 de fevereiro de 1967 ampliou as determinações presentes no Decreto de lei n․ 53 quanto à organização das universidades federais. Ele instituía o sistema departamental e reduzia a autonomia da cátedra, integrada agora definitivamente no departamento universitário (FÁVERO, 2000). Este passa a ser a menor unidade da estrutura universitária para a organização administrativa, didático-científica e de distribuição de pessoas, compreendendo as disciplinas afins, professores e pesquisadores com objetivos comuns (ARAÚJO E VIANNA, 2008a).

Essas mudanças irão contribuir para 0 isolamento dos pedagogos e das faculdades de educação, retirando-os do convívio desses professores das demais áreas, pois com a fragmentação das Faculdade de Filosofia, Ciências e Letras, os espólios destas serão distribuídos entre departamentos isolados (ARAÚJO E VIANNA, 2008).

A Lei no 5.540, de 28 de novembro de 1968, fixava as normas de organização e funcionamento do ensino superior no Brasil, determinando que a formação de professores para o ensino de segundo grau, tanto das disciplinas gerais como das técnicas, fosse feita em nível superior, nas universidades, devendo a fixação do currículo mínimo e da duração mínima dos cursos serem feitas pelo Conselho Federal de Educação (ALVES 2010).

Em 1971, a Lei 5.692 de diretrizes e bases para o ensino de $1^{\circ}$ e $2^{\circ}$ Graus fixou a formação mínima para o exercício do magistério no formato de licenciatura curta. $O$ artigo 26 desta Lei materializou-se na Indicação 23/73 e as Resoluções 30/74 e 37/75 do Conselho Federal de Educação, definindo os cursos de licenciaturas para 0 ensino de $1^{\circ}$ e $2^{\circ}$ graus e fixando um currículo mínimo para o curso de Licenciatura em Ciências. Este currículo seria imposto no País, sendo o modelo único e obrigatório de licenciatura da área. Assim, deixariam de existir as licenciaturas plenas em Biologia, Física e 
Química, sendo substituídas por um único curso que forma, em tempo reduzido, o professor polivalente (ARAÚJO E VIANNA, 2008).

Tanto as universidades maiores e mais antigas, quanto as sociedades científicas, manifestaram repulsa e indignação diante dessa resolução e isso fez com que o MEC adiasse a obrigatoriedade de sua implantação, e criasse uma comissão de especialistas para re-examinar a proposta. Na 27aㅡ Reunião Anual da SBPC, em 1975, se evidenciou esse conflito e a Assembléia Geral da Sociedade Brasileira de Física, aprovou uma moção contrária à Resolução 30/74. (Ibidem)

O documento gerado pela comissão de especialistas do MEC foi considerado inaceitável pelas sociedades científicas. Assim a SESU propôs que estas sociedades elaborassem um conjunto de propostas para o problema da carência de professores. A Sociedade Brasileira para o Progresso da Ciência, em 1981, publicou um conjunto de sugestões para a formação de professores da área de Ciências para as escolas de $1^{\circ}$ e $2^{\circ}$ graus. (Ibidem)

Em síntese, a proposta defendia que a formação de professores para $01^{\circ}$ e $2^{\circ}$ Graus para a área de Ciências e Matemática deveria ser feita em cursos de licenciatura plena específicos, tal que o curso de licenciatura plena em Matemática daria a habilitação para o ensino desta no $1^{\circ}$ e $2^{\circ}$ graus; os cursos de licenciatura em Biologia, Física e Química, separadamente, dariam a habilitação para o ensino de Biologia, Física e Química, respectivamente, no $2^{\circ}$ Grau. A formação pedagógica do licenciando também deveria incluir obrigatoriamente disciplinas que abordem a história e a filosofia da Educação e preparar o professor para a sala de aula por meio de disciplinas especiais, tais como as práticas de ensino e a instrumentação para o ensino (Ibidem).

Nesse cenário as licenciaturas plenas nos moldes defendidos pelas sociedades científicas e pelas universidades mais antigas continuaram a existir. Cursos de licenciatura curta também foram criados.

O período dos anos 80 caracterizou-se pela existência de intensos debates, tanto no que concerne à formação de professores, quanto no campo dos estudos curriculares. Assim, entrou em foco a necessária revisão da escola básica e dos cursos de licenciatura.

O "esquema $3+1$ " tem estado presente entre as questões 
mais emblemáticas relacionadas à formação de professores, sobre as quais muito se discutiu no âmbito da história recente da educação. A principal crítica feita a esse modelo aponta a pouca valorização dada aos saberes pedagógicos, que acabavam se constituindo em um apêndice do bacharelado, colaborando para que os cursos de licenciatura tenham reduzido o seu prestígio acadêmico (ALVES, 2010).

\subsection{Breves considerações sobre as "Diretrizes Nacionais Curriculares para os Cursos de Física"}

Entendendo o campo das políticas públicas como um campo de disputa, no qual diferentes sujeitos sociais lutam pela legitimidade de suas propostas, não podemos deixar de aqui mencionar as "Diretrizes Nacionais Curriculares para os Cursos de Física" e a ambigüidade marcada pela existência de duas diretrizes essencialmente contraditórias.

O Parecer CNE/CES aprovado em 06 de novembro de 2001, e homologado em 07 de dezembro de 2001, apresenta as "Diretrizes Nacionais Curriculares para os Cursos de Física". Isso significa que essas diretrizes foram aprovadas posteriormente a "Diretrizes Curriculares Nacionais para a Formação de Professores da Educação Básica", porém esse parecer foi homologado antes.

No entender desse documento os cursos de física, tendo um núcleo básico comum oferecem habilitações distintas, dentre as quais está o "Físico Educador": Esse perfil é definido como o físico que:

dedica-se preferencialmente à formação e à disseminação do saber científico em diferentes instâncias sociais, seja através da atuação no ensino escolar formal, seja através de novas formas de educação científica, como vídeos, "software", ou outros meios de comunicação. (BRASIL, 2001, p. 3)

Segundo o parecer a estrutura do curso deve ter duas partes. Um núcleo comum a todas as modalidades de cursos de física, e um módulo seqüencial especializado onde se dará a orientação final do curso. Esses módulos podem "conter o conjunto de atividades necessárias para completar um Bacharelado ou Licenciatura em Física nos moldes atuais ou poderão ser diversificados" (p.5).

Embora na descrição dos módulos sequenciais, seja 
mencionado que para a Licenciatura em Física devam ser consideradas as "Diretrizes Curriculares para Formação de Professores da Educação Básica" bem como bem como as "Diretrizes Nacionais para a Educação Básica e para - Ensino Médio", esse parecer não trata a licenciatura com nenhuma especificidade.

\subsection{Modelos Atuais de Formação de Professores}

A Lei de Diretrizes e Bases da Educação Nacional (LDBEN), de 1996, estabelece como condição necessária ao docente que leciona na Educação Básica o título de Licenciatura Plena.

Segundo a LDBEN (BRASIL, 1996) os cursos de licenciatura devem adquir terminalidade $\mathrm{e}$ integralidade própria em relação ao Bacharelado, constituindo-se em um projeto específico. Isso exigiria a definição de currículos próprios da Licenciatura que não se confundam com o Bacharelado ou com a formação de professores que ficou caracterizada como modelo " $3+1$ ".

Apesar dessa sinalização, é apenas com a publicação, em 2002, das "Diretrizes Curriculares Nacionais para a Formação de Professores da Educação Básica" que os cursos de licenciatura, em sua maioria, começam algum movimento para se adequar, ao menos, às exigências mais explícitas da resolução que institui as novas diretrizes.

É importante mencionar também a existência das "Diretrizes Nacionais Curriculares para os Cursos de Física" parecer N. ${ }^{\circ}$ : CNE/CES 1.304/2001, homologado em 7/12/2001, que em relação a formação do licenciando não chega a constituir uma "nova perspectiva", mas sinaliza aspectos. Essa legislação será apresentada brevemente ao fim dessa sessão.

\subsubsection{A Instauração das Diretrizes Nacionais para Formação de} Professores da Educação Básica

Após a promulgação da LDBEN de 1996, a complexidade em torno do delineamento da formação de professores no país revelava a urgente necessidade de diretrizes curriculares, que orientassem as instituições de ensino na organização dos cursos de licenciatura. 
O processo de elaboração de tais diretrizes havia sido iniciado logo após a promulgação da LDBEN de 1996, com a designação, pela SESU (Secretaria de Ensino Superior), por meio do Edital oํ 4, de 3 de dezembro de 1997, de comissões de especialistas para esse fim.

As Diretrizes Curriculares Nacionais para a Formação de Professores da Educação Básica, em Nível Superior, Curso de Licenciatura, de Graduação Plena, são apresentadas nos seguintes documentos: Parecer CNE/CP oㅜ 9, de 8 de maio de 2001, Parecer CNE/CP №28/2001 de 02 de outubro de 2001, Resolução CNE/CP no 1, de 18 de janeiro de 2002.

O Parecer CNE/CP no 9 de 08 de maio de 2001, homologado em 18 de janeiro de 2002, é um documento extenso, que faz uma discussão sobre a educação no Brasil nesse inicio de século, e a partir daí, detalha a formação que seria desejável ao professor.

O PARECER CNE/CP 28 de 02 de outubro de 2001, homologado em 18 de janeiro de 2002, dá nova redação ao Parecer CNE/CP 21/2001, traz alguns esclarecimentos, e institui a duração e a carga horária dos cursos de Formação de Professores da Educação Básica, em nível superior, curso de licenciatura, de graduação plena. Esse documento determina que:

(...) à luz das diretrizes curriculares nacionais da formação docente, o tempo mínimo para todos os cursos superiores de graduação de formação de docentes para a atuação na educação básica para a execução das atividades científico-acadêmicas não poderá ficar abaixo de 2000 horas, sendo que, respeitadas as condições peculiares das instituições, estimula-se a inclusão de mais horas para estas atividades. Do total deste componente, 1800 horas serão dedicadas às atividades de ensino/aprendizagem e as demais 200 horas para outras formas de atividades de enriquecimento didático, curricular, científico e cultural. Estas 2000 horas de trabalho para execução de atividades científico-acadêmicas somadas às 400 horas da prática como componente curricular e às 400 horas de estágio curricular supervisionado são o campo da duração formativa em cujo terreno se plantará a organização do projeto pedagógico planejado para um total mínimo de 2800 horas. Este total não poderá ser realizado em tempo inferior a 3 anos de formação para todos os cursos de licenciatura inclusive o curso normal superior.(BRASIL 2002, p. 13)

Ainda em 18 de fevereiro de 2002 é publicada a Resolução CNE/CP01/2002 que Institui Diretrizes Curriculares Nacionais para a Formação de Professores da Educação Básica, em nível superior, curso de licenciatura, de graduação plena. 
Esse cenário obrigou a maioria dos cursos de licenciatura do país a passarem por adequações, visando cumprir a nova legislação. Os pareceres acima mencionados foram homologados em 2002, e o prazo dado aos cursos de licenciatura para adequação foi o ano de 2005, inicialmente. Depois esse prazo foi estendido até 2006.

\subsubsection{Aspectos Gerais}

O texto das novas Diretrizes contido no Parecer CNE/CP no 9/2001, é um texto completo, que embasa os artigos da Resolução CNE/CP no1/2002, trazendo uma discussão das propostas e ideias que estão presentes na resolução. O Parecer CNE/CP n28/2001 traz alguns esclarecimentos complementares e institui a duração e carga horária dos cursos.

Antes de nos debruçarmos especificamente sobre os trechos trazidos pelos documentos que se fazem necessários a reflexão aqui proposta, faremos uma apresentação de caráter mais geral.

O documento parecer CNE/CP ํㅜ 9/2001, é dividido em dois grandes blocos, o primeiro, a saber, o "Relatório" e o segundo, o "Voto da Relatoria". Embora as muitas discussões sejam recorrentes e se apresentem de forma difusa ao longo de todo o documento, tentaremos explicitar a lógica na qual foram organizadas.

O "Relatório" é subdividido nos itens: "A Reforma da Educação Básica"; "Suporte Legal para a Formação de Professores" e "Questões a Serem Enfrentadas na Formação de Professores". O objetivo dessa primeira parte do Parecer é o de caracterizar a realidade educacional brasileira, sistematizar pontos principais da reforma pretendida pela LDBEN e trazer essas mesmas discussões para dentro da temática da formação de professores. Isso sinaliza o movimento de pensar e sistematizar os problemas educacionais, o que se pretende da educação básica nesse início de século e o que se espera do professor nesse cenário. E é o que se pretende desse professor, que deve orientar e balizar sua formação.

Dentre os problemas citados a serem enfrentados na formação de professores, há os que se situam no campo institucional, dentre os quais a segmentação da formação, o isolamento das escolas de formação, e o 
distanciamento da educação básica. E há também os que se situam no campo curricular, dentre os quais: tratamento inadequado dos conteúdos, tratamento restrito da atuação profissional e concepção restrita da prática, inadequação do tratamento da pesquisa, e outros.

Diante do quadro de desafios apresentado pelo "Relatório" o texto passa ao "Voto da Relatoria". Esse segundo bloco se organiza por: "Princípios Orientadores para uma Reforma da Formação de Professores", "Diretrizes para a Formação de Professores" e "Diretrizes para a Organização da Matriz Curricular".

As discussões apresentadas implicam na redefinição de objetivos formativos, e, portanto, na redefinição de currículos e práticas. A concepção de competência como orientadora dos processos de formação, implica repensar os currículos e o papel dos conteúdos nos mesmos. Isso aliado ao conceito de coerência, entre a formação oferecida, e o que se espera do futuro professor, e ao pensar a pesquisa como elemento formativo essencial, compõem os "Princípios Orientadores para uma Reforma da Formação de Professores".

As "Diretrizes para a Formação de Professores" então se apresentam como: concepções, competências a serem desenvolvidas na educação básica, conhecimentos para o desenvolvimento profissional, organização institucional da formação, e a avaliação dessa formação.

Isso se materializa nas "Diretrizes para Organização da Matriz Curricular", que propõe que se tome o conjunto de competências que se quer que o professor constitua ao invés de partir de uma listagem de disciplinas obrigatórias. Nessa lógica o documento apresenta alguns "eixos articuladores", sobre os quais deve se organizar o currículo.

Por fim, o documento ressalta que as referidas diretrizes apresentam a flexibilidade necessária para que cada instituição construa seus próprios projetos.

\subsubsection{Alguns Destaques}

Do documento Parecer CNE/CP n 9/2001, faremos a discussão mais detalhada de alguns trechos, os quais servirão de base para 
situarmos, tanto a questão das finalidades educativas expressas no documento, quanto a questão dos espaços e formas ocupados pelo saber específico e sua relação com os saberes pedagógicos.

$\mathrm{Na}$ introdução do "Relatório", já são apontadas algumas questões emblemáticas no que se refere ao perfil do professor que se deseja formar. Assim são estabelecidas as finalidades das diretrizes, dentre as quais as de fomentar processos de mudança nas instituições formadoras e atualizar e aperfeiçoar currículos, considerando as mudanças em curso na organização pedagógica e curricular da educação básica.

O primeiro item abordado no "Relatório" é justamente a "Reforma da Educação Básica". São ressaltados tanto a LDBEN como os PCNs como instrumentos de transformação da realidade da educação básica. Ao começar uma discussão sobre as diretrizes para formação de professores, problematizando uma esperada mudança na educação básica, podemos perceber que há uma especial atenção à finalidade dos cursos de licenciatura. Essa configuração corrobora a perspectiva trazida por Chervel (1992), de que em momentos de reforma os objetivos educacionais ficam mais explícitos.

O "Suporte Legal para a Formação de Professores", é abordado dentro do "Relatório", onde o texto traz as bases legais do documento, destacando vários aspectos da LDBEN de 1996. Dentre os aspectos destacados está a ênfase na formação de nível superior como desejável e indispensável à qualidade da formação docente. É enfatizado também o papel dos Institutos Superiores de Educação, como instâncias necessárias dentro das instituições que pretendem formar professores, para promover condições de aproximação entre as diferentes licenciaturas.

Dentre as "Questões a Serem Enfrentadas na Formação de Professores", a Licenciatura em Física se enquadra no que o documento denomina de grupo de licenciaturas que formam especialistas por área de conhecimento ou disciplina, que comumente tem em seu foco os conteúdos específicos da área, em detrimento de um trabalho mais aprofundado sobre os conteúdos específicos que serão desenvolvidos no ensino fundamental e médio. Nesses casos o aprender da prática docente fica locada num segundo pólo de disciplinas que supervalorizam o fazer pedagógico, desprezando a dimensão teórica dos conhecimentos específicos como instrumento de 
seleção e análise contextual das práticas. Assim o momento de colocar esses conhecimentos em prática fica apenas para o estágio supervisionado.

Dentre esses mesmos aspectos, destacados como desafios a enfrentar, está o tratamento inadequado dos conteúdos. Sobre isso o documento cita que nem sempre há clareza sobre quais são os conteúdos que o professor em formação deve aprender, visto que a distinção entre o conhecimento do objeto e sua expressão escolar (também chamada de transposição didática) nem sempre é levada em consideração. Segundo o documento:

\begin{abstract}
Sem a mediação da transposição didática, a aprendizagem e a aplicação de estratégias e procedimentos de ensino tornam-se abstratas, dissociando teoria e prática. Essa aprendizagem é imprescindível para que, no futuro, o professor seja capaz tanto de selecionar conteúdos como de eleger as estratégias mais adequadas para a aprendizagem dos alunos, considerando sua diversidade e as diferentes faixas etárias. (BRASIL 2002, p. 20)
\end{abstract}

Nesse discurso se evidencia uma concepção de formação que valoriza a dimensão da didática específica. Aqui se ressalta a insuficiência do professor deter o conhecimento específico, justificando que é preciso dominar as metodologias, técnicas e estratégias que permitam selecionar e transpor esse conhecimento para distintos contextos, e em especial, para a educação básica.

Outro aspecto destacado como desafio a ser enfrentado nos cursos tradicionais de formação é a "desconsideração das especificidades próprias das etapas da educação básica e das áreas de conhecimento que compõem o quadro curricular na educação básica”. Nesse item é ressaltado que principalmente no Ensino Médio, o professor deve compreender o papel de cada disciplina, considerando sua articulação com outros saberes. Para tanto, requer-se que o futuro professor saiba situar os saberes disciplinares no conjunto do conhecimento escolar e que possa superar a fragmentação apontando para uma construção integral do currículo.

Dentre os "Princípios Orientadores para uma Reforma da Formação de Professores" se destaca a noção de "Competência" entendida como a mobilização dos conhecimentos do professor, transformada em ação.

Vale destacar também o princípio da "Coerência entre a formação oferecida e a ação esperada do futuro professor". É aí que se insere 
o conceito de "Simetria Invertida". Nesse conceito se reconhece o papel da experiência do sujeito enquanto aluno, como constitutiva da atuação docente que ele exercerá no futuro, e assim se recomenda atenção e coerência em todo o processo de formação. Isso significa que o aluno deve vivenciar as atitudes, modelos didáticos, capacidades e modos de organização que se pretende, venham a ser concretizados em suas práticas futuras.

É discutida ainda como subitem ligado ao "princípio da coerência", uma concepção de aprendizagem, que leve em consideração a noção de competência de forma não dicotômica com a concepção de conteúdo. Ao se referir, no subitem seguinte, à “concepção de conteúdo", o documento destaca que é preciso que os conteúdos sejam analisados e abordados de modo a fazer uma rede de significados. É sugerida ainda como alternativa, a abordagem por projetos ou situações problemas, que inclusive, transponham as barreiras disciplinares.

$\mathrm{Na}$ explanação sobre "A pesquisa como elemento essencial na formação do professor", fica destacado que o processo de ensinoaprendizagem dos conteúdos deve ser o foco dessas pesquisas, pois isso é um elemento que permitirá ao futuro professor refletir sobre a sua própria prática. No que se refere à dimensão da pesquisa sobre o conhecimento específico o documento destaca que:

É importante todavia, para a autonomia dos professores, que eles
saibam como são produzidos os conhecimentos que ensina, isto é,
que tenham noções básicas dos contextos e dos métodos de
investigação usados pelas diferentes ciências, para que não se
tornem meros repassadores de informações. Esses conhecimentos
são instrumentos dos quais podem lançar mão para promover
levantamento e articulação de informações, procedimentos
necessários para ressignificar continuamente os conteúdos de
ensino, contextualizando-os nas situações reais.

Além disso, 0 acesso aos conhecimentos produzidos pela investigação acadêmica nas diferentes áreas que compõem seu conhecimento profissional alimenta o seu desenvolvimento profissional e possibilita ao professor manter-se atualizado e fazer opções em relação aos conteúdos, à metodologia e à organização didática dos conteúdos que ensina. (BRASIL 2002, p. 35)

No que concerne as "concepções" no item "As diretrizes para formação de professores", vale destacar o item intitulado: "A seleção dos conteúdos das áreas de ensino da educação básica deve orientar-se por e ir além daquilo que os professores irão ensinar nas diferentes etapas da 
escolaridade". Nesse item fica claro que para que seja possível a transposição didática dos conteúdos é necessário que o professor detenha um conhecimento da área específica, ampliado e aprofundado. Nas palavras do documento:

... definir o que um professor especialista, em uma determinada área de conhecimento, precisa conhecer sobre ela, não é fácil. Também, nesse caso, é fundamental que o currículo de formação não se restrinja aos conteúdos a serem ensinados e inclua outros que ampliem o conhecimento da área em questão. Entretanto, é fundamental que ampliação e aprofundamento do conhecimento tenham sentido para o trabalho do futuro professor. (BRASIL 2002, p. 39)

Outro item que é interessante destacar é o intitulado: "Os conteúdos a serem ensinados na escolaridade básica devem ser tratados de modo articulado com suas didáticas específicas". Mais uma vez ressaltando o papel das didáticas específicas e mencionando o papel do conhecimento específico o documento aponta que:

Os professores em formação precisam conhecer os conteúdos definidos nos currículos da educação básica, pelo desenvolvimento dos quais serão responsáveis, as didáticas próprias de cada conteúdo e as pesquisas que as embasam. É necessário tratá-los de modo articulado, o que significa que o estudo dos conteúdos da educação básica que irão ensinar deverá estar associado à perspectiva de sua didática e a seus fundamentos (BRASIL 2002, p. 39).

Ainda sobre as "concepções", no item "Diretrizes para formação de professores" é mencionada a importância da autonomia dos futuros professores, que deve ser construída mediante uma concepção de avaliação que permita que o futuro professor invista em seu processo de aprendizagem, construindo um percurso pessoal de formação.

Passando às "Competências" ainda dentro do item "Diretrizes para formação de professores" vem a descrição das competências a serem desenvolvidas na educação básica. Dentre elas destacamos as “Competências referentes ao domínio dos conteúdos a serem socializados, de seus significados em diferentes contextos e de sua articulação interdisciplinar". Aqui o texto explicita que o professor deve ser capaz de relacionar os conteúdos básicos das disciplinas a movimentos atuais e a aspectos da vida pessoal, social e profissional dos alunos.

Depois das competências temos a menção aos 
"Conhecimentos para o desenvolvimento profissional" onde o texto coloca como necessária a contextualização dos conteúdos visando o conhecimento da educação em sua dimensão cultural, social, política e econômica.

Como um desses conhecimentos destacamos os "Conteúdos das áreas de conhecimento que são objeto de ensino" do qual retiramos o trecho:

Nos cursos de formação para as séries finais do ensino fundamental e ensino médio, a inovação exigida para as licenciaturas é a identificação de procedimentos de seleção, organização e tratamento dos conteúdos, de forma diferenciada daquelas utilizadas em cursos de bacharelado; nas licenciaturas, os conteúdos disciplinares específicos da área são eixos articuladores do currículo, que devem articular grande parte do saber pedagógico necessário ao exercício profissional e estarem constantemente referidos ao ensino da disciplina para as faixas etárias e as etapas correspondentes da educação básica. (BRASIL 2002, p. 47)

Nesse sentido o parecer destaca que, são critérios de seleção de conteúdo para um curso de licenciatura:

a) a visão da própria área de conhecimento que o professor em formação deve construir;

b) o domínio de conceitos e de procedimentos que o professor em formação trabalhará com seus alunos da educação básica;

c) as conexões que ele deverá ser capaz de estabelecer entre conteúdos de sua área com as de outras áreas, possibilitando uma abordagem de contextos significativos.

$(\ldots)$

Convém destacar a necessidade de contemplar na formação de professores conteúdos que permitam analisar valores e atitudes. Ou seja, não basta tratar conteúdos de natureza conceitual e/ou procedimental. É imprescindível que o futuro professor desenvolva a compreensão da natureza de questões sociais, dos debates atuais sobre elas, alcance clareza sobre seu posicionamento pessoal e conhecimento de como trabalhar com os alunos. (BRASIL 2002, p. 48)

Quanto aos "conhecimentos pedagógicos", o documento

destaca a importância do conhecimento advindo da experiência, para a construção de uma conexão entre teoria e prática.

Depois da discussão dos "Conhecimentos para 0 desenvolvimento profissional" passa-se à "Organização institucional da formação de professores". Aqui é ressaltada a necessidade, de que cursos de licenciatura com identidade própria, mantenham estreita parceria com os 
institutos e departamentos das áreas específicas, e que constituam colegiados próprios, que tomem decisões sobre a organização institucional e sobre questões administrativas. Essa organização deve incluir na sua jornada de trabalho tempo e espaço para discussões coletivas. É ainda reiterada a exigência (exceto para as instituições que detêm autonomia universitária) da criação de Institutos Superiores de Educação para congregar licenciaturas de áreas diferentes.

Dispondo das "Diretrizes para Organização da Matriz Curricular dos Cursos de Formação de Professores", são elencados 6 eixos articuladores das dimensões que precisam ser contempladas na formação profissional docente. São eles:

- Eixo articulador dos diferentes âmbitos de conhecimento profissional;

- Eixo articulador da interação e comunicação e do desenvolvimento da autonomia intelectual e profissional;

- Eixo articulador entre disciplinaridade e interdisciplinaridade,

- O eixo que articula a formação comum e a formação específica;

- Eixo articulador dos conhecimentos a serem ensinados e dos conhecimentos educacionais e pedagógicos que fundamentam a ação educativa;

- Eixo articulador das dimensões teóricas e práticas.

Vale destacar a posição de estímulo a iniciativas inovadoras, como se pode perceber na frase: "a equipe de formadores deve buscar formas de organização, em contraposição a formas tradicionais concentradas exclusivamente em cursos de disciplinas" (p.51).

Para a organização da matriz curricular o documento deixa claro que ao invés de se partir de uma lista de disciplinas obrigatórias e cargas horárias, deve-se tomar como referência o conjunto das competências que se quer que o professor constitua no curso, bem como a alocação de tempos e espaços curriculares.

Quanto à relação entre os conhecimentos específicos e os conhecimentos que fundamentam a ação pedagógica, o documento destaca novamente a importância de que o curso contemple e facilite a realização da transposição didática. 
Para que se organize a matriz curricular partindo dessas diretrizes o documento deixa claro que:

Esse exercício vai requerer a atuação integrada do conjunto dos professores do curso de formação visando superar o padrão segundo - qual os conhecimentos práticos e pedagógicos são responsabilidade dos pedagogos e os conhecimento específicos a serem ensinados são responsabilidade dos especialistas por área de conhecimento. (BRASIL 2002, p. 56)

Nesse sentido é instituída como obrigatória a "Prática como componente curricular" que difere da prática de ensino, devendo ser uma atividade flexível, que deve ser planejada quando da elaboração do projeto pedagógico e seu acontecer deve se dar desde o início da duração do processo formativo e se estender ao longo de todo o seu processo, em articulação intrínseca com o estágio supervisionado e com as atividades de trabalho acadêmico.

\section{O Parecer CNE/CP 28/2001, traz esclarecimentos} complementares a respeito da "Prática como Componente Curricular":

A prática como componente curricular é, pois, uma prática que produz algo no âmbito do ensino. Sendo a prática um trabalho consciente cujas diretrizes se nutrem do Parecer 9/2001 ela terá que ser uma atividade tão flexível quanto outros pontos de apoio do processo formativo, a fim de dar conta dos múltiplos modos de ser da atividade acadêmico-científica. Assim, ela deve ser planejada quando da elaboração do projeto pedagógico e seu acontecer deve se dar desde o início da duração do processo formativo e se estender ao longo de todo o seu processo. Em articulação intrínseca com o estágio supervisionado e com as atividades de trabalho acadêmico, ela concorre conjuntamente para a formação da identidade do professor como educador.(...) A prática, como componente curricular, que terá necessariamente a marca dos projetos pedagógicos das instituições formadoras, ao transcender a sala de aula para o conjunto do ambiente escolar e da própria educação escolar, pode envolver uma articulação com os órgãos normativos e com os órgãos executivos dos sistemas. Com isto se pode ver nas políticas educacionais e na normatização das leis uma concepção de governo ou de Estado em ação. Pode-se assinalar também uma presença junto a agências educacionais não escolares tal como está definida no Art. 1ํ da LDB. Professores são ligados a entidades de representação profissional cuja existência e legislação eles devem conhecer previamente. Importante também é o conhecimento de famílias de estudantes sob vários pontos de vista, pois eles propiciam um melhor conhecimento do ethos dos alunos. (p. 9)

\subsubsection{Significando as Diretrizes Nacionais para a Formação de Professores para a Educação Básica}

Procuraremos evidenciar que nas diretrizes curriculares existe 
uma polifonia, que interpretaremos como resultado da recontextualização por hibridismo de diferentes discursos teóricos advindo do meio acadêmico.

Primeiramente, no que concerne ao currículo da Licenciatura e da Escola Básica, podemos perceber que as diretrizes apresentam um interesse em integração curricular. Nesse sentido se argumenta em prol da consciência, por parte do futuro professor, da delimitação de dada área de conhecimento e a da articulação dessa com as demais áreas.

Ainda não exatamente da perspectiva curricular crítica, as diretrizes falam na autonomia do futuro professor e ressaltam que para isso é requerido um saber a respeito de como são produzidos os conhecimentos das áreas científicas. Não fica claro, no entanto, se esse conhecimento "epistemológico" teria algum potencial transformador, afinal como já comentamos, existem diversas visões sobre o conhecimento científico, algumas das quais bastante equivocadas e mistificadoras.

Há menção ainda a um conhecimento específico "aprofundado e ampliado" das áreas disciplinares, que deve ter sentido para o futuro professor. Aqui pode se interpretar que há indícios do propósito de pensar os conteúdos específicos em sintonia com a finalidade da licenciatura, mas ficam dúvidas sobre o que possa ser esse conhecimento "aprofundado e ampliado".

Trechos seguintes sugerem o pensar os conteúdos específicos associados a suas didáticas específicas, o que evoca uma concepção mais técnica, voltada ao "como ensinar". Por outro lado, se enfatiza que os conteúdos da educação básica devem ser tratados relacionados com aspectos sociais da vida dos alunos, o que evoca concepções de ensino mais ligadas a aportes sociológicos.

No que diz respeito à organização curricular das licenciaturas em si, a ênfase em não se partir de uma lista de conteúdos, nos parece sinalizar uma aporte que foge um pouco da racionalidade técnica (mas é ainda tradicional, com o aporte de Tyler, por exemplo). Propõe-se que sejam definidas as competências, e que os conteúdos específicos sejam tratados como eixos articuladores. Isso reconhece que os conhecimentos não têm valor em si só, e que devem estar condicionados às finalidades formativas.

No que concerne aos "saberes do professor" podemos situar a questão dos "Saberes específicos" e os "Saberes pedagógicos", dentro do 
discurso oficial dos documentos.

Há, claramente no documento, uma crítica ao modelo de formação " $3+1$ ", que se expressa, dentre outras, na falta de articulação entre o núcleo de conhecimentos de natureza específica (os saberes de física) e os conhecimentos que fundamentam a prática educativa (saberes pedagógicos). Há também um indicativo da necessidade de superação dessa fragmentação, bem como da problematização dos saberes específicos.

Podemos fazer uma sistematização dos vários momentos em que o texto aborda a questão:

- dentre os problemas a ser enfrentados, quando destaca que, nas licenciaturas há um foco nos conteúdos específicos da área em detrimento dos conteúdos que serão desenvolvidos na educação básica,

- quando é citado que há um tratamento inadequado dos conteúdos, nos cursos de licenciatura, visto que a distinção entre o conhecimento do objeto e sua expressão escolar nem sempre é levada em consideração,

- quando a noção de competência é apontada como nuclear no novo projeto de formação de forma não dicotômica com a noção de conteúdo,

- quando se destaca que os conteúdos precisam ser analisados de modo a fazer uma rede de significados,

- quando se enfatiza que o aprofundamento e ampliação do conhecimento específico deve ter sentido para o trabalho do futuro professor,

- quando cita-se que o estudo dos conteúdos da educação básica deverá estar associado à perspectiva de sua didática e a seus fundamentos,

- quando recomenda-se que a identificação de procedimentos, seleção, organização e tratamento dos conteúdos seja feita de forma diferenciada daquela utilizada em cursos de bacharelado, 
- quando reconhece-se que há critérios próprios para seleção de conteúdos para um curso de licenciatura,

- quando se destaca que os conteúdos devem permitir que se analisem valores e atitudes

- porque um dos eixos para organização da matriz curricular é definido como "Eixo articulador dos conhecimentos a serem ensinados e dos conhecimentos educacionais e pedagógicos que fundamentam a ação educativa",

- quando se enfatiza a importância de que o curso contemple e facilite a realização da transposição didática, relacionando os conhecimentos específicos aos conhecimentos que fundamentam a ação pedagógica,

- quando é instituída a "Prática como Componente Curricular".

No que concerne às concepções de professor aí implícitas, podemos apontar a hibridização de concepções teóricas distintas.

Em alguns momentos, os apontamentos e encaminhamentos referentes a uma maior articulação entre os saberes específicos e pedagógicos, parecem se centrar num paradigma mais relacionado às didáticas específicas. Nesse caso o processo de transposição didática, ou seja, a expressão escolar dos conhecimentos específicos é o saber a ser valorizado. Isso se faz levando-se em consideração as técnicas e metodologias próprias do ensino de cada área do conhecimento.

Sinaliza-se então a existência de um bloco de saberes integradores. Nessa visão o repertório dos saberes docentes seria composto por: saberes específicos, saberes pedagógicos e saberes da didática específica, que deteriam esse papel integrador.

Essa abordagem teórica reconhece a autoridade do saber de referência, e toma para si a preocupação com métodos, abordagens e estratégias que permitam a seleção e o ensino desse saber. Podemos aproximar essa abordagem da concepção da racionalidade técnica. 
Em contraposição, outros trechos apresentam um questionamento mais profundo sobre os conteúdos específicos que devem ser ensinados nos cursos de licenciatura. Isso aparece quando são enaltecidos fatores externos de significação dos conteúdos como a relevância social do conhecimento, e é ressaltada a importância de questionar o saber de referência enquanto corpo de conhecimentos rígido, com relações préestabelecidas e acabadas.

Ao se reconhecer, ainda, que esses conteúdos devem ser tratados como eixos articuladores com o saber pedagógico, está se problematizando o próprio "saber específico", no contexto das licenciaturas.

A partir do momento que se admite que os conteúdos não se justificam por si só, e que devem responder a finalidades formativas específicas das licenciaturas, se questiona o saber disciplinar de referência. $E$ se essas finalidades se apoiam em relacionar os conteúdos básicos das disciplinas aos movimentos atuais e aos aspectos da vida pessoal, social e profissional dos alunos, se explicita um maior alinhamento teórico com as perspectivas críticas.

Ficam assim abertas diferentes possibilidades de entender como as diretrizes propõem que o conhecimento específico seja tratado de maneira mais integrada.

No discurso dos documentos como um todo, entendidos como recontextualização de alguns discursos da academia, podemos identificar ainda outros marcos teóricos que irão hibridizar com os marcos já apontados.

Podemos identificar a presença do marco teórico da racionalidade prática, pois outro problema apontado como importante de ser superado, é a dicotomia entre teoria e prática. O discurso do documento menciona várias vezes a importância da reflexão do professor sobre a própria prática, e a importância de uma atitude de pesquisa frente aos problemas de ensino aprendizagem.

Na noção de competência, tida como nuclear na concepção de formação, e apontada como finalidade sobre a qual deve se fundar a matriz curricular, vemos a presença de outro marco teórico.

Podemos perceber que a recontextualização desses marcos teóricos podem lhes conferir novos sentidos e finalidades, é por isso que 
achamos importante identificá-los. Paradigmas aparentemente contraditórios são conciliados e seus discursos de misturam de forma difusa. Essa hibridação responde a necessidade de obter legitimidade junto a diferentes sujeitos sociais e contextos.

A tabela 3.2 traz uma sistematização dos marcos teóricos em alguns trechos das diretrizes, bem como, uma interpretação possível sobre a articulação entre os saberes.

\begin{tabular}{|c|c|c|}
\hline \multirow{2}{*}{ Exemplo de Trechos das Diretrizes } & \multicolumn{2}{|c|}{ Significação } \\
\hline & Marcos teóricos & $\begin{array}{l}\text { Articulação dos } \\
\text { Saberes }\end{array}$ \\
\hline $\begin{array}{l}\text { "Sem a mediação da transposição didática, a } \\
\text { aprendizagem e a aplicação de estratégias e } \\
\text { procedimentos de ensino tornam-se abstratas" }\end{array}$ & $\begin{array}{c}\text { Racionalidade } \\
\text { Técnica }\end{array}$ & $\begin{array}{lr}\text { Estratégias } & \text { e } \\
\text { procedimentos } & \text { de } \\
\text { ensino próprios } & \text { de } \\
\text { cada conteúdo } & \\
\end{array}$ \\
\hline $\begin{array}{l}\text { "Convém destacar a necessidade de } \\
\text { contemplar na formação de professores } \\
\text { conteúdos que permitam analisar valores e } \\
\text { atitudes. (...)É imprescindível que o futuro } \\
\text { professor desenvolva a compreensão da } \\
\text { natureza de questões sociais, dos debates } \\
\text { atuais sobre elas, alcance clareza sobre seu } \\
\text { posicionamento pessoal e conhecimento de } \\
\text { como trabalhar com os alunos" }\end{array}$ & Intelectual Crítico & $\begin{array}{l}\text { Relação entre os } \\
\text { conteúdos, valores e } \\
\text { atitudes, questões } \\
\text { sociais, } \\
\text { posicionamento } \\
\text { pessoal e o trabalho } \\
\text { com o aluno }\end{array}$ \\
\hline $\begin{array}{l}\text { “... a construção de competências, para se } \\
\text { efetivar, deve se refletir nos objetos da } \\
\text { formação, na eleição de seus conteúdos, na } \\
\text { organização institucional, na abordagem } \\
\text { metodológica" }\end{array}$ & Perrenoud & $\begin{array}{l}\text { Saberes devem se } \\
\text { mobilizar na ação por } \\
\text { meio de uma } \\
\text { competência }\end{array}$ \\
\hline $\begin{array}{l}\text { "atuação prática possui uma dimensão } \\
\text { investigativa e constitui uma forma não de } \\
\text { simples reprodução mas de criação ou, pelo } \\
\text { menos, de recriação do conhecimento" }\end{array}$ & Saberes da Prática & $\begin{array}{l}\text { A prática é produtora } \\
\text { de novos significados } \\
\text { e conhecimentos, que } \\
\text { só podem ser obtidos } \\
\text { por meio da reflexão } \\
\text { sobre a ação }\end{array}$ \\
\hline
\end{tabular}

Tabela 3. 2 - Significação das diretrizes

Faz-se necessário ainda, destacar algumas outras ambiguidades, significativas por se remeterem a aspectos curriculares e estruturais.

Se por um lado iniciativas inovadoras são incentivadas, por outro, em muitos trechos do texto, é possível interpretar que as inovações devam se dar por meio de seminários, atividades em grupo, projetos e outras alternativas, o que permitiria ao núcleo estruturante do curso permanecer estável.

Em relação à estrutura institucional também é possível 
encontrar pontos de divergência. Por um lado, se estimula a proximidade dos cursos de licenciatura dos institutos de referência, e o pensar das práticas e reflexões pedagógicas em sintonia com os conteúdos específicos a serem ensinados na educação básica. Por outro lado, se insiste na criação dos Institutos Superiores de Educação como elemento centralizador das áreas comuns a todas as licenciaturas.

A "prática como componente curricular" é instituída como elemento de integração, pretendendo superar o padrão pelo qual a problematização de aspectos mais práticos e ligados à escola fica apenas para o momento do estágio supervisionado. Ficam, no entanto, muitas dúvidas sobre o que isso representa em termos mais concretos. O texto apresenta uma redação bastante vaga e confusa quando da delimitação desses elementos.

A pluralidade de significados existentes no discurso oficial, associados aos processos que ocorrem na interação desse discurso com outros contextos é um dos cenários que justifica essa pesquisa.

\subsubsection{Breves considerações sobre a repercussão das diretrizes}

Nessa etapa do trabalho apresentaremos algumas críticas e interpretações que foram feitas ao discurso oficial contido nas diretrizes. Pretendemos com essas breves considerações, apenas ilustrar um cenário de disputa, que denuncia a complexidade da situação, na qual diferentes grupos tentam legitimar suas áreas e propostas. Segundo Dias (2010):

\footnotetext{
Resultam desse processo complexo de produção de políticas, documentos de definição curricular marcados pela ambivalência ao incorporar diferentes projetos em disputa em meio a um complexo processo de negociação de diferentes sentidos nos quais diferentes grupos e sujeitos lutam pela legitimidade de suas proposições. (DIAS, 2010, p.4)
}

De certa forma, é consenso entre a comunidade de pesquisadores em educação que as diretrizes representam um avanço em relação à formação de professores. No entanto algumas críticas, bastante incisivas e pertinentes, refletem a falta de consenso dessa comunidade em torno de várias questões relacionadas à formação docente.

Segundo Alves (2010), apesar de as diretrizes incorporarem 
elementos positivos construídos historicamente a partir das discussões teóricas e debates sobre o tema, os documentos têm no estabelecimento da noção de competência, como aspecto nuclear na orientação dos cursos de formação de professores, o seu principal motivo de controvérsias. A noção de competência adotada é criticada por expressar uma visão instrumental e utilitarista ${ }^{4}$ da formação de professores, característica da tendência tecnicista que vigorava anteriormente.

Para Silva (2005) a implementação destas Resoluções do Conselho Nacional de Educação pode ter resultado na negação do papel formador que cabe à área de educação, decorrentes da banalização e/ou negação do conhecimento educacional. Nas palavras da autora:

A questão central passou a ser aritmética: impregnados por uma cultura organizacional legalista, acostumada ao estabelecimento de currículos mínimos para cursos de graduação, aliada aos eternos embates bacharelado e licenciatura, o resultado imediato dessas resoluções para nossa universidade se reduziu ao loteamento de horas na grade curricular, com conseqüências desastrosas para a construção do conhecimento dos futuros professores. (SILVA 2005, p.6)

Outras críticas bastante recorrentes vêm de autores mais ligados aos campos específicos da educação, como o campo da didática. Para Martins e Romanowski (2010) a perda de espaço da didática numa perspectiva mais ampla e a valorização das didáticas específicas e metodologias específicas das áreas de conhecimento nas atuais propostas de formação de professores é expressão de um novo momento do capitalismo. Nessa perspectiva, a preparação do professor é feita com recursos técnicos, tendo em vista posterior aplicação no espaço escolar.

Para Veiga (2007) a figura dominante dentro da reforma detalhada pelas diretrizes é o professor na perspectiva do tecnólogo de ensino, que se define pela lógica do poder constituído, e procura adequar a formação de professores às demandas do mercado globalizado.

Embora não estejamos alinhados, com esses autores e suas posições, queremos ilustrar algumas das criticas de distintos grupos de especialistas, em espaços de disputa. Isso porque qualquer legislação não se restringe a um plano de aplicação de regras e diretrizes, mas se insere como

\footnotetext{
${ }^{4}$ Essa crítica à noção de competência é uma discussão mais ampla, que incide inclusive sobre os Parâmetros Curriculares Nacionais para o Ensino Básico.
} 
ingrediente na construção do conhecimento da própria área.

Em nossa visão, as diretrizes representam sim um avanço ao se pensar a formação de professores e não pode ser encarada como uma expressão direta de poder ou manipulação de um grupo dominante, ou dos grandes paradigmas econômicos. Como tentamos elucidar, ela é um discurso difuso, representante de várias esferas acadêmicas e políticas, que tenta conciliar, inclusive, visões de mundo diferentes entre si.

Quanto ao conceito de "competência", que é frequentemente associado a uma visão tecnicista, vemos com desconfiança as acusações de que por meio dele, se aproxima necessariamente a educação da lógica de mercado. Mesmo dentro do contexto educacional essa expressão pode assumir diferentes significados e estar associada a matrizes teóricas distintas.

Ramos (2001) ao discutir especificamente a pedagogia por competências indica três matrizes teóricas distintas que levam a diferentes compreensões desse conceito: a matriz comportamentalista; a matriz funcionalista e a matriz construtivista. Segundo Silva (2006), há um número significativo de defensores de que a pedagogia por competências se associa à noção de eficácia. Nesse sentido o autor argumenta que pode-se assumir essa compreensão se entendermos a competência dentro de uma matriz comportamentalista. Essa matriz teórica, no entanto, não é a única possibilidade de situar o conceito de competência.

A nosso ver, da maneira como são usadas e sugeridas, tanto nos PCNs quanto na diretriz para formação de professores aqui pesquisada, as competências se oferecem como uma alternativa ao tradicional modo de pensar o currículo a partir de conteúdos. Pensar o currículo desse modo significa considerar que os saberes que irão compor currículo não podem ser apenas saberes que se justificam por si só, mas que devem se mobilizar para alguma finalidade. Essa asserção nos parece positiva e também operacional como modo de organizar diretrizes e parâmetros curriculares.

Consideramos de grande valia o esforço de articulação que essas diretrizes enfatizam como necessário. Acreditamos na potencialidade do diálogo entre as diferentes áreas, e em especial entre a área de educação e as áreas de conhecimento específico. É preciso evitar as concepções generalistas e simplistas e as acusações que frequentemente são veiculadas 
entre as áreas. Acreditamos que é preciso transformar as críticas em mote para um diálogo construtivo.

\subsection{Algumas considerações sobre o momento atual e os discursos oficiais}

No que concerne ao momento atualmente vivido pelas licenciaturas não podemos deixar de chamar a atenção para a ambiguidade marcada pela existência de duas diretrizes essencialmente contraditórias.

Claramente as diretrizes para os cursos de física ignoram toda a proposta de mudança trazida pelas diretrizes para formação de professores, assim como aspectos significativos da LDBEN. Esse documento basicamente referenda o modelo " $3+1$ ", sinalizando que primeiro o licenciando deve adquirir as competências gerais em física e depois uma formação complementar acordada com os profissionais da área de educação.

Nas palavras Oliveira (2006):

Enquanto a formação do físico-educador é preconizada em módulos, resguardando sua formação específica aos institutos ou departamentos de Física e sua formação pedagógica às faculdades de Educação, o documento de formação de professores expõe sua preocupação com essa formação descontextualizada e desconectada. (p. 55)

O modelo de formação "3+1" ainda se mostra fortemente arraigado inclusive no campo de produção dos discursos oficiais. No caso da licenciatura em física isso é um forte exemplo de como os discursos dos físicos e dos educadores chegam a estabelecer uma forma de esquizofrenia em relação ao que seja um curso de licenciatura. É claro que essa realidade complica ainda mais as definições e redefinições, no âmbito dos cursos, em seus currículos e práticas. Vemos com preocupação o quanto a área de física se mostra resistente e avessa ao diálogo e às perspectivas de mudança.

Chama a atenção ainda o fato de que, até hoje, ou seja, passados cerca de dez anos da publicação dos dois documentos, nenhum órgão oficial tenha se debruçado sobre essa questão, optando por legitimar um documento e desconsiderar o outro. Essa "dualidade" não está superada no âmbito de produção dos discursos oficiais e ainda foi muito pouco discutida em outros espaços. 


\section{CAPÍTULO 4}

\section{Formação de Professores, Educação Básica e Ensino de Ciências}

O ensino deve ser de modo a fazer sentir aos alunos que aquilo que se Ihes ensina é uma dádiva preciosa e não uma amarga obrigação.

Albert Einstein

Pensar a formação de professores numa perspectiva coerente com nossas premissas teóricas, apresentadas nos capítulos um e dois, prescinde também da compreensão de relações que envolvem a escola básica. Isso se vê claramente se nos propomos a pensar o currículo de um curso superior de formação de professores trazendo à tona a pergunta: "Qual é a finalidade de um curso de Licenciatura em Física?"

A resposta aparentemente simples a essa pergunta, consistiria no enunciado de que, um curso de licenciatura em física, tem a finalidade de formar professores de física para escola básica. A aparente simplicidade da resposta pode ser rejeitada, logo de inicio, se assumirmos a pluralidade de sentidos que estão presentes nas concepções: de professor, de conhecimento e de finalidade educativa.

Nos capítulos anteriores procuramos, justamente, evidenciar a complexidade que está envolvida nas noções de conhecimento, conhecimento escolar, disciplina e nas várias concepções e entendimentos acerca da atividade docente.

Nesse sentido, vimos uma possibilidade em estabelecer uma importante correlação, na qual assumimos que o currículo da formação de professores tem, ou deveria ter, uma relação estreita com os currículos da escola básica. Isso porque a própria existência do curso de Licenciatura em 
Física está condicionada à existência da disciplina de Física na escola Básica. Segundo Lopes (2008):

As disciplinas escolares reúnem pessoas e instituições em busca de
status, recursos e território. Orientam a produção de diplomas, o
cumprimento de exigências sociais, os critérios para formação de
professores, a divisão do trabalho docente - mecanismos que são
sustentados pelas disciplinas escolares e ao mesmo tempo as
sustentam. (LOPES, 2008, P. 55)

Pretendendo situar nosso problema de análise e compreender melhor as relações implícitas faremos um breve e sucinto percurso histórico pelos Currículos da escola básica e pelo Ensino de Ciências no Brasil.

Embora nosso foco de pesquisa esteja mais dirigido ao momento atual e que queiramos, de fato, investigar um contexto marcado por possíveis mudanças desencadeadas com a publicação de normas e diretrizes nacionais nos últimos anos, parece-nos imprescindível estabelecer um contexto histórico mais abrangente. Buscaremos, então, nesse breve percurso histórico, compreender alguns indícios sobre a forma pela qual determinados padrões se estabeleceram ao longo do tempo.

Esse percurso histórico e as relações que pretendemos explorar entre a educação básica, o ensino de ciências e a formação de professores, prepara também "o solo" para adentrarmos ao próximo âmbito de investigação: o da Pesquisa em Ensino de Ciências. E isso porque a própria Pesquisa em Ensino de Ciências tem uma relação que é, em certo sentido, intrínseca à perspectiva que o Ensino de Ciências pode assumir na educação básica.

Esse capítulo está organizado primeiramente a fim de resgatar algumas origens da escola secundária e do ensino de ciências no Brasil. Em seguida adentramos mais especificamente ao período que vai da Primeira Lei de Diretrizes e Bases da Educação Nacional de 1961 até os dias atuais. Por fim procuraremos evidenciar algumas relações entre a escola básica, o ensino de ciências e a formação de professores.

\subsection{Algumas origens da Escola Secundária}

Enquanto a educação primária no começo do século $X X$ teve um lugar central nos projetos de modernização da sociedade brasileira, os 
estudos secundários demarcaram características muito diferenciadas (SOUZA 2008). Centraremos essa breve análise mais especificamente nos processos históricos do ensino secundário, uma vez que é a esse nível de ensino que se destina a formação de professores que é nosso objeto de reflexão.

O nível de estudos secundários tratava, na época da Primeira República, da educação de um grupo muito restrito de jovens herdeiros de oligarquias agrárias, grandes comerciantes, profissionais liberais e etc, cuja formação se fundamentava nos estudos desinteressados e expressava distinção cultural (SOUZA, 2008).

Essa formação merecedora de status era balizada pela manutenção de uma alta cultura na qual prevaleciam os estudos literários, embora estivessem presentes também os estudos científicos. Toda essa distinção cultural, não obstante, servia a uma específica finalidade: a preparação para ingresso em cursos superiores. Nesse sentido se buscava a preparação cultural adequada aos jovens que exerceriam funções de destaque na sociedade (Ibidem).

A formação humanística, que visava preparar os jovens para acenderem aos níveis mais altos de pensamento e da criação humana se caracterizava como herança da tradição dos Colégios, instituições que se constituíram na Europa desde o século XVI. Nesses moldes o ensino se apresentava numa configuração histórica do saber, pautado na unidade do conhecimento e, portanto, alheio, ainda, à fragmentação disciplinar.

Esse ensino de feição clássica humanista é dominante no cenário que remonta à história do ensino secundário no Brasil, em parte por herança do ensino dos colégios jesuítas. Essa mesma feição vem, depois, a se consolidar nos primeiros planos de estudos do Colégio Dom Pedro II, instituição que se tornaria a principal referência para os demais estabelecimentos de ensino secundário do país (Ibidem).

Segundo Chervel e Compére (apud Souza (2008)), a especialização disciplinar se estabeleceria de maneira duradoura exatamente a partir da atualização cultural advinda da crítica à cultura clássica humanista. Esse movimento consistia na valorização da língua nacional, da literatura, das línguas vivas e da história, e na inclusão do conhecimento científico, mesmo que ainda em posição secundária. 
A tensão gerada pelos confrontos entre a cultura científica e a cultura literária marcou o final do século XIX, com o decurso das transformações ligadas à ciência moderna, que questionou tanto a forma de conceber o mundo quanto a relação dos homens com o saber. A polêmica que envolve a disputa entre estudos científicos e literários passa então a fazer parte do cenário educacional.

Em 1890, Benjamin Constant, então Ministro da Instrução Pública, Correios e Telégrafos, implementa uma reforma que visava ampliar a educação científica no ensino secundário. Ele estabelece um plano de estudos com base nas ciências fundamentais, que segundo Silva apud Souza (2008) elevaria a um grau extremo a tendência ao enciclopedismo. Essa orientação não chega a se consolidar, pois, regulamentos posteriores, estabelecidos pelo Colégio Dom Pedro II, reformaram o programa.

Assim, no começo do século XX, no Brasil, existiam apenas tradições curriculares, visto que não havia se difundido ainda nenhuma proposta sistemática de currículo. Nessas tradições, principalmente no que concerne ao ensino secundário, se misturavam filosofias, dentre as quais, os princípios da educação jesuíta (MOREIRA, 1997). Segundo Figueiredo apud Moreira (1997), essas tradições traziam como marcas:

a) ênfase em disciplinas literárias e acadêmicas

b) enciclopedismo

c) divisão entre trabalho intelectual e manual.

A atuação do governo federal limitou-se, durante muito tempo, à manutenção do Colégio Dom Pedro II que, de certa forma, passava a estabelecer o padrão para as escolas secundárias.

Destaca-se, ainda, a marca de um ensino secundário de caráter seletivo, de função propedêutica, e que constituía uma educação das elites. Dessa forma, a escola média refletia a própria organização social brasileira àquela época, com uma restrita elite em transformação, mas blindada das questões sociais mais amplas.

Esse ensino de caráter elitista trazia a marca positivista. Para a educação elementar predominava a ênfase nos métodos apropriados, que permitiriam o ensino de qualquer coisa. Para o ensino secundário era 
conferida uma feição literária e currículos enciclopédicos (MOREIRA, 1997).

Em 1909 foram criadas as Escolas de Aprendizes e Artífices visando a preparação de jovens para diferentes ofícios e destinada a uma camada menos favorecida da população. Consequentemente se criou uma barreira social entre os dois tipos de ensino, o ensino secundário humanista e desinteressado e o ensino profissional técnico e utilitário (SOUZA, 2008).

A década de 20 é marcante para o contexto educacional, pois delimita tentativas de reorganização da educação, que vem no bojo de mudanças políticas, redefinição das funções do estado e estabelecimento de novos rumos econômicos (MOREIRA, 1997).

No entanto a reforma do sistema escolar brasileiro estabelecida pelo governo em 1925 pouco alterou a estrutura do nível secundário de ensino. Segundo Souza (2008):

Os reformadores ratificaram o sentido unitário da escola secundária como escola de formação das elites dirigentes, destinada apenas àqueles que pudessem desfrutar de uma educação prolongada, e voltada para os estudos de nível superior e com base em uma sólida cultura geral (p.110).

Apesar dessas limitações a reforma acabou enfatizando a seriação, a freqüência obrigatória e redefiniu o programa de estudos com ampliação da referência nacional e com o aumento do número de aulas de Português e das disciplinas científicas. Segundo Souza (2008) os alunos do curso secundário deveriam estudar 25 matérias diferentes. O que seria chamado de uma "sólida cultural geral", correspondendo a uma síntese de tradição e modernidade, acabou se traduzindo em um enciclopedismo desmedido, com o aumento das disciplinas previstas e dos conteúdos prescritos.

Não obstante, a década de 1920 foi marcada por intensos debates, que colocaram em discussão tanto a legitimidade dos estudos literários e científicos como as finalidades do ensino secundário.

E são as ideias da Escola Nova que irão influenciar os movimentos desencadeados em alguns estados Brasileiros, como Bahia, Minas Gerais e Rio de Janeiro (MOREIRA, 1997).

$\mathrm{Na}$ perspectiva escolanovista as mudanças da sociedade impunham uma nova concepção da escola secundária, mais ampliada e 
diversificada.

$\mathrm{Na}$ visão de alguns educadores como Fernando de Azevedo, a chave do problema do ensino secundário estava na fixação da finalidade, que deveria abdicar de preocupações utilitárias e profissionais e se basear em uma sólida cultura geral a fim de formar as elites e a classes médias do país (SOUZA, 2008).

Já o movimento cujo ícone foi Anísio Teixeira, incorpora elementos da concepção progressivista de educação e segundo Moreira (1997):

Pela primeira vez, disciplinas escolares foram consideradas
instrumentos para o alcance de determinados fins, ao invés de fins
em si mesmas, sendo-lhes atribuído o objetivo de capacitar os
indivíduos a viver em sociedade. Tal concepção implicou a ênfase
não só no crescimento intelectual do aluno, mas também em seu
desenvolvimento social, moral, emocional e físico. (MOREIRA, 1997,
p. 88)

Há nesse momento histórico uma diversidade de entendimentos sobre qual deveria ser o objetivo do curso secundário. Ele era defendido ora como etapa preparatória ao ensino superior, ora como espaço de construção de uma cultura geral sólida ora como tendo também responsabilidades quanto à formação profissional.

E nesse cenário demarcado por distintas posições no que se refere à questão da finalidade do ensino secundário ainda se somam os embates entre os estudos literários e os estudos científicos.

Segundo Souza (2008) apesar do ímpeto das propostas inovadoras, a permanência, em linhas gerais, dos padrões instituídos, denota a finalidade considerada socialmente legítima da educação secundária: "a de ser a expressão de uma cultura destinada a poucos" (p.143).

O período da década de 1930 a 1960 foi marcado por duas reformas educacionais nacionais: A reforma Francisco Campos e a reforma Capanema.

A reforma Campos ocorrida no início da década de 1930 levou em consideração algumas das bandeiras levantadas pelos escolanovistas, como a preparação dos jovens para a vida. Uma das mais importantes inovações da reforma foi a divisão do curso secundário em dois ciclos: o formativo e o propedêutico. 
O primeiro ciclo de cinco anos foi concebido como ciclo comum e estaria destinado à formação geral do adolescente. O segundo ciclo, de dois anos, previa uma preparação para os cursos superiores e seria dividido em três seções garantindo matérias específicas a cada ramo profissional: o curso Jurídico, os cursos de Medicina, Farmácia e Odontologia e os cursos de Engenharia, Arquitetura e Química Industrial (SOUZA, 2008).

Em 1931 a carga horária das matérias da área de ciências foi ampliada denotando maior importância atribuída aos conteúdos científicos. O objetivo da disciplina de ciências físicas e naturais, segundo o programa de 1931 era: "dar uma noção geral dos fenômenos da natureza e suas aplicações mais comuns à vida cotidiana, nas cidades e nos campos, de acordo com o desenvolvimento da civilização da nossa época". As instruções metodológicas indicavam a experimentação e a observação dos fenômenos naturais e abrangia conteúdos como a atmosfera; calor e luz; água, oxidação e redução; a vida; a terra; magnetismo e eletricidade; os seres vivos; o som; a sociedade (SOUZA, 2008).

Segundo Freitas apud Souza (2008) a reforma Francisco Campos conferiu uma identidade ao secundário e promoveu sua metodização assentando as bases preliminares de uma pedagogia da educação secundária.

Para Souza (2008) a reforma Francisco Campos encontrou condições favoráveis para a concretização de parte de suas disposições normativas. A seleção curricular estabelecida instaurou um campo de legitimidade que se "entrecruzaria com o processo de profissionalização das ciências no país, com a formação de professores nas recém criadas Faculdades de Filosofia, Ciências e Letras e com a produção de material didático" (SOUZA, 2008, p.161).

A reforma Capanema iria, na sequência, instaurar as bases sobre as quais ocorreria a expansão do ensino nas décadas seguintes. Embora sem um estrito rompimento com o passado, surgiriam inovações significativas. A atuação de Capanema visou colocar a educação a serviço do projeto autoritário e nacionalista do governo durante o Estado Novo (ibidem).

Nesse período foi privilegiada a formação geral desinteressada atendendo aos interesses dos grupos conservadores. $E$ assim se 
estabeleceram dois ciclos. O primeiro, denominado ginasial, compreendendo um curso geral de duração quatro anos e o segundo com duração de três anos oferecendo duas modalidades paralelas: o clássico e o científico (ibidem).

A divisão entre clássico e científico segundo o próprio ministro Gustavo Capanema não foi pensada com base em ramos diferentes da vida escolar ou como especialização e sim como uma diversificação dos setores de ensino superior, identificando-se com áreas mais afinadas às ciências ou áreas mais afinadas às letras (ibidem).

Segundo Souza (2008) apesar de a organização dos programas estarem se adequando a princípios mais modernos de estruturação dos conteúdos, em unidades (e não mais em lições), com explicitação das finalidades, instruções metodológicas e técnicas de ensino, ainda prevalecia a pretensão de tudo ensinar:

Para cada disciplina, os conteúdos selecionados incluíam um vasto campo de saberes desdobrados em conceitos, noções, fatos, informações, minúcias, aprofundamentos. O cumprimento dos programas tornava-se impraticável. Além disso, o rígido sistema de avaliação reiterava processos de ensino mais tradicionais inviabilizando justamente outros fatores, o emprego de metodologias mais progressistas (SOUZA, 2008, p.185).

Esse período marcou profundas alterações principalmente quanto à expressiva expansão do sistema secundário no Brasil. A democratização desse nível de ensino caminhava a passos largos na medida em que se intensificava a demanda das classes média e popular por esse setor.

O conservadorismo dessas escolas aliado ao flagrante desajuste entre os princípios da escola para classe dominante e a gradual democratização em curso acarretaria graves e variados problemas (ABREU apud SOUZA, 2008).

E diante desse cenário Anísio Teixeira, já diretor do Instituto Nacional de Pesquisas Educacionais (INEP), adverte que a mudança da clientela da escola secundária mudaria inevitavelmente essa mesma escola. Teixeira advogava por uma educação técnica que deveria ser comum a todos os homens, o que significava adotar programas com atividades na "diverssísima variedade de suas aptidões, ensinando pouco e bem" (TEIXEIRA apud SOUZA, 2008 p.117). 
Já o educador Fernando de Azevedo faz a defesa de um novo humanismo para o ensino secundário, preconizando que era preciso superar as controvérsias entre ciências e letras, pois a ameaça maior residiria na transformação do secundário em educação técnica para o trabalho (SOUZA, 2008).

Destaca-se desse período, segundo Souza (2008) que:

Em posição muito mais confortável, as disciplinas científicas teriam confirmado seu lugar proeminente e decisivo no currículo do secundário, fosse ele organizado com base na concepção de cultura geral ou de formação para o trabalho (SOUZA, 2008, p. 224).

\subsection{Panorama a partir da Lei de Diretrizes e Bases da Educação Nacional de 1961}

A primeira Lei de Diretrizes e Bases da Educação Nacional (LDB) data de 1961. Essa lei buscou conciliar posições polêmicas, assegurou a liberdade de ensino, afrouxou os mecanismos de controle das escolas privadas e atendeu a reivindicações pela descentralização e flexibilidade, conferindo aos Estados competência para organização de seus sistemas de ensino.

Em 1962 o Conselho Federal de Educação indicou as matérias obrigatórias ao ensino de nível médio (subseqüente ao primário): Português, História, Geografia, Matemática e Ciências (sob a forma de iniciação à ciência, duas séries, sob a forma de ciências físicas e biológicas, 4 séries)

Segundo Souza (2008) com essa resolução do conselho a hegemonia das humanidades caia definitivamente em ruínas, pois estava explicitada a tendência que se tornaria predominante até então, isto é, "o encontro da cultura científica e técnica e seu prestígio em detrimento das humanidades" (p.234).

Segundo resolução do CNE de 1962 as disciplinas Iniciação à Ciência e Ciências Físicas e Biológicas deveriam desenvolver hábitos e atividades peculiares aos que se dedicavam à pesquisa científica. Por esta razão, os métodos indicados eram aqueles mais concernentes ao método científico, incentivando no aluno o hábito de consulta à biblioteca, de observação e experimentação. No segundo ciclo, a diversificação das matérias Física, Química e Biologia permitiria a sistematização e o aprofundamento 
necessários à preparação dos alunos que desejassem as carreiras de maior conteúdo de ciências experimentais.

Ainda sobre os movimentos que incidiram sobre a escola secundária nos anos 60 é importante mencionar as concepções da Tecnologia Educacional associadas ao discurso desenvolvimentista, a ênfase no uso de recursos tecnológicos no ensino e o crescimento da abordagem sistêmica tomada como aplicação do conhecimento científico à educação (SOUZA, 2008).

Durante as décadas seguintes a influência norte americana e sua tendência tecnicista vai ganhando espaço nas escolas brasileiras, inclusive por meio da assinatura de acordos de cooperação internacional. $O$ Programa de Assistência Brasileiro-Americana ao Ensino Elementar (PABEE) é um ícone desse processo.

Pode-se dizer que a tendência tecnicista, embora permeada de ideias progressivistas, torna-se pouco a pouco predominante no Brasil, como fica evidente na proposta de Marina Couto, publicada nos anos sessenta (MOREIRA, 1997).

Segundo Moreira (1997) não podemos falar de um processo de simples transferência dos referenciais tecnicistas americanos, visto que existiriam outras opções, como o próprio Tyler, já discutido. Para Moreira, essa influência tecnicista americana foi marcada pela convergência explícita de interesses do governo da ditadura militar com a promessa de controle e eficácia que o tecnicismo oferece.

A lei $n^{05} 5.692$ de 1971 fixou novas "diretrizes e bases para o ensino de $1^{\circ}$ e $2^{\circ}$ graus" e orientou uma ampla reforma. Entre as modificações mais importantes instituídas está a extensão da escolaridade obrigatória e a tentativa da eliminação da dualidade entre escola primária e ginásio por meio da criação do ensino de 1ำ grau com duração de oito anos (SOUZA, 2008).

O ensino de $2^{\circ}$ Grau seria constituído tanto de escolas técnicas profissionalizantes quanto de escolas de educação geral. Novamente veio à tona um embate expressivo sobre a relevância e a prioridade entre educação geral e formação profissional, sobre as finalidades do ensino médio e sua relação com a educação superior. A elaboração do currículo seguiu ditames da abordagem tecnicista em voga no campo, dando ênfase aos 
objetivos gerais e específicos, discriminando o conteúdo programático e sugerindo atividades. A importância conferida aos objetivos fazia eco à valorização da eficácia e da eficiência (ibidem).

Segundo Souza (2008) a universalização do ensino de $1^{\circ} \mathrm{grau}$ e expansão contínua do $2^{\circ}$ grau colocariam a educação escolar como uma experiência fundamental na vida da maioria das crianças e dos jovens: "Uma escola dilacerada pela nostalgia do passado e as exigências do presente impelida à redefinição de sua cultura e de seus significados (p.285)." A autora afirma ainda que:

De um modo geral, pode-se dizer que o novo desenho curricular significou o privilegiamento de saberes instrumentais para a vida social em conformidade com os valores da sociedade urbanoindustrial-tecnológica e o deslocamento definitivo das humanidades para a cultura científica (p.285).

Havia nessa reforma a instituição de núcleo comum de especificações dentre as quais vigorava a matéria Ciências constituída de Matemática e Ciências Físicas e Biológicas.

As Ciências deveriam contribuir para o desenvolvimento do pensamento lógico e a vivência do método científico, das tecnologias e suas aplicações. A função desse ensino era tornar o aluno capaz de explicar o meio próximo e remoto desenvolvendo o espírito de investigação, invenção e iniciativa (ibidem).

Segundo Souza (2008) nesse período o "ensino de ciências" ganharia maior destaque e maior espaço nos currículos, sob enfoque não mais da aquisição de informações pertinentes aos produtos da ciência, e sim adotando um enfoque investigativo e experimental. Para Zancul apud Souza (2008) essa identificação dos processos de ensino com os processos de pesquisa estiveram na base da concepção de ensino de ciências pelo método científico.

Essa preponderância assumida pela ciência e pela tecnologia refletia valores da sociedade do final do século XX: a eficiência, a racionalidade, o pragmatismo, a rapidez, a aplicação imediata, a objetividade. Destaca-se então a prioridade da cultura científica na seleção cultural escolar, também influenciada pela hegemonia dos campos de conhecimento científico nas universidades, e reforçados pelas políticas de financiamento da ciência e 
da tecnologia (SOUZA, 2008).

Nesse sentido podemos afirmar que todo esse período é marcado pela consolidação de uma educação básica centrada nos elementos da cultura científica.

Faz-se importante ainda ressaltar que nas décadas finais do Século XX a democratização do acesso ensino em todos os níveis foi expressiva, tornando esse um direito efetivo para a grande maioria da população brasileira.

O período definido a partir da década de 1980 foi marcado pela abertura política e pela reconstrução dos espaços coletivos de discussão e de movimentos da sociedade civil organizada. Nesse período os encontros da Associação Nacional de Pesquisa e Pós-Graduação em Educação (ANPED) são emblemáticos no que diz respeito às discussões educacionais, e as perspectivas de reforma na educação brasileira (MOREIRA, 1997).

A preocupação com o fracasso escolar no ensino de primeiro grau das camadas mais carentes da população ganha espaço central nos debates sobre o currículo da escola básica. Assim a busca de reformas e reestruturações curriculares entra na agenda de autoridades, pesquisadores e educadores.

Nesse cenário vale destacar os intensos debates entre duas vertentes que problematizam e propõem mudanças nos currículos da escola básica: A pedagogia social dos conteúdos e o movimento da Educação Popular.

A Pedagogia Social dos Conteúdos, vertente representada dentre outros, pelos educadores brasileiros Saviani e Libâneo, rejeita a ênfase na metodologia característica do movimento escolanovista, sobre o qual recai a culpa pela má qualidade na instrução das camadas menos favorecidas. Os conteudistas defendem um resgate da função dos conteúdos na educação, pois a transmissão de conhecimento é a função básica da escola. Além disso, defendem como objeto principal da escola um conhecimento objetivo universal que deve ser organizado seqüencial e gradativamente, para ser melhor ensinado (SILVA, 2010, MOREIRA, 1997, MOREIRA, 2010).

Já a educação popular da qual o maior ícone é sem dúvida o educador brasileiro Paulo Freire, defende uma educação emancipatória para 
as camadas populares, que Ihes permita compreender e superar as condições de opressão à qual estão submetidos. Freire critica a invasão cultural praticada pelos conteúdos ditos universais e objetivos, e defende que o processo de educação deve ser dialógico, assumindo uma postura de respeito em relação a outras formas de conhecimento. Ele defende que é a partir delas que se deve construir o diálogo com os conteúdos, cuja aprendizagem deve se justificar na transformação do mundo (FREIRE 1977, FREIRE 1996, MOREIRA, 1997, ZANETIC, 1989).

Embora as duas vertentes explicitem uma preocupação com a educação das camadas menos favorecidas, os conteudistas crêem que só o acesso ao conhecimento erudito, ao conhecimento da elites podem dar ao sujeito condições de superar suas limitações. Nesse movimento não há espaço para os saberes populares. Já a educação popular, propõe que se problematize o conhecimento das camadas sociais menos favorecidas e sua relação com o saber erudito e com as injustiças da sociedade de classes.

Moreira (1997) resume as tensões em torno das questões curriculares no Brasil ao fim da década de oitenta como tensões entre: transmissão do saber $x$ produção do saber; aquisição do saber $x$ conscientização; saber erudito x saber popular.

A década de 1990 é marcada no contexto sócio político pelo cenários de expansão do neoliberalismo e pelo processo de globalização. Organismos internacionais (UNESCO, Banco Mundial, etc.) passam a compor o cenário das reformas educacionais, principalmente nos países periféricos ao cenário econômico dominante. De certa forma, criam tensão nesse processo, tanto o ajuste dos sistemas educacionais às demandas da nova ordem do mundo do trabalho e do capital, quanto às demandas por uma efetiva democratização do acesso ao conhecimento em todos os seus níveis.

Em 1996, é promulgada a nova Lei de Diretrizes e Bases da Educação Nacional. Essa lei vem reafirmar o dever do estado em oferecer ensino fundamental público e gratuito a toda a população brasileira, e prevê gradativa universalização do ensino médio. Quanto aos objetivos educacionais a lei enfatiza "o pleno desenvolvimento do educando, seu preparo para o exercício da cidadania e preparação para o trabalho." (BRASIL, 1996, Lei nำ9394/1996, Art. $2^{\circ}$ ). 
Quanto ao currículo reconhece-se que deve haver uma base comum e uma parte diversificada. Como obrigatórios são instituídos o estudo da língua portuguesa e da matemática, o conhecimento do mundo físico e natural e da realidade social e política, especialmente do Brasil (BRASIL, 1996, Lei nำ394/1996, Art. 26 §1ำ.

Em 1997 são publicados os Parâmetros Curriculares Nacionais (PCN) para o Ensino Fundamental, e no ano 2000 os Parâmetros Curriculares Nacionais para o Ensino Médio (PCNEM).

Em 2002 foram publicados os $\mathrm{PCN}+$, que são documentos mais completos, divididos por grandes áreas, que pretendem dar mais subsídios para implementação do "Novo Ensino Médio". Fica explícito que:

O novo ensino médio, nos termos da lei, de sua regulamentação e encaminhamento, deixa de ser, portanto, simplesmente preparatório para o ensino superior ou estritamente profissionalizante, para assumir necessariamente a responsabilidade de completar a educação básica. Em qualquer de suas modalidades, isso significa preparar para a vida, qualificar para a cidadania e capacitar para o aprendizado permanente, em eventual prosseguimento dos estudos ou diretamente no mundo do trabalho. (BRASIL, 2002 p.3)

O volume dedicado especialmente às Ciências da Natureza e à Matemática procura trazer elementos de utilidade para o professor de cada disciplina, na definição de conteúdos e na adoção de opções metodológicas, bem como formas de articulação das disciplinas para organizar, conduzir e avaliar o aprendizado. Contudo é enfatizado que:

... o conjunto desses novos conteúdos não constituirá uma lista única de tópicos que possa ser tomada por um currículo mínimo, porque é simplesmente uma proposta, nem obrigatória nem única, de uma visão ampla do trabalho em cada disciplina (BRASIL, 2002, p.9).

Fica bem explícito tanto nos PCNEM como nos PCN + que o novo ensino médio deve se estruturar em termos de competências e não apenas em termos de conteúdos. Argumenta-se que as próprias formas de organização do conhecimento, as disciplinas, têm passado por contínuos rearranjos. Muitas disciplinas acadêmicas e campos da cultura são resultados de processos de sistematização recente de conhecimentos práticos ou teóricos, reunindo elementos que, em outras épocas, estavam dispersos em distintas especialidades.

Por fim, podemos sistematizar que a década de 1990 e os anos 2000 foram marcados pelas publicações de leis, diretrizes e parâmetros, 
que tentaram desencadear mudanças. Muitas dessas propostas ainda encontram grandes resistências, e o Ensino Médio vive ainda fortes resquícios da concepção de educação propedêutica, da concepção enciclopédica do início do século XX, e do tecnicismo que instaurou durante décadas.

A crise na educação parece se agravar cada vez mais, visto que esses valores resistentes do passado, respondem cada vez menos às necessidades de um mundo em constantes e cada vez mais rápidas transformações.

Fazem-se necessárias mudanças no Ensino Médio, e assim como rezam os $\mathrm{PCN}$, é inaceitável a manutenção de um ensino propedêutico com objetivos expressos em termos de listas de tópicos a partir da premissa de que o domínio de cada disciplina é requisito necessário e suficiente para o prosseguimento dos estudos.

Segundo os PCN+ o ensino médio desejável é aquele do qual o aluno egresso saiba: se informar, se comunicar, argumentar, compreender e agir, enfrentar problemas de qualquer natureza, participar socialmente, de forma prática e solidária, ser capaz de elaborar críticas ou propostas e, especialmente, adquirir uma atitude de permanente aprendizado (BRASIL, 2002a, p.3).

Para tanto, argumentamos que a formação de professores para esse ensino médio, não pode ser feita nos mesmos moldes da formação tecnicista, que vigora também em muitas de nossas universidades, há muitas décadas.

\subsection{Algumas relações com a formação de professores}

Se assumirmos que os paradigmas vigentes $e$ as configurações curriculares de um curso de licenciatura têm correlação com os currículos da escola básica, esses breves apontamentos permitem vislumbrar alguns possíveis paralelos. Essas relações não são necessariamente decorrências cronológicas umas das outras, na medida em que o contexto educacional é muito mais abrangente, mas sugerem a existência de aspectos importantes a serem considerados.

A sistematização dos currículos da escola básica data do início 
do século vinte, assim como as primeiras preocupações com a formação de professores. A expansão da oferta educacional e a existência das primeiras escolas que atenderiam a uma demanda da classe trabalhadora criam tanto uma necessidade de regulação quanto uma necessidade de formação de professores em um número muito maior.

As décadas de vinte e trinta são marcadas por mudanças estruturais na política e na economia e demarcam um campo fértil na área de educação. Alguns pioneiros, como Anísio Teixeira, e o paradigma da "Escola Nova", irão influenciar tanto as propostas de mudanças curriculares na escola básica, quanto as primeiras preocupações com a formação docente.

$E$ isso porque a preocupação com saberes próprios à formação docente era ausente, mesmo nas escolas de formação de professores para o ensino primário. $O$ que vigorava era uma ênfase nos conteúdos de ensino.

O modelo $3+1$ representa, então, à época em que foi instaurado, um avanço, no sentido em que se reconhece a necessidade de uma formação específica e uma licença a quem deseja ensinar no ensino secundário. Ainda que com espaço restrito no currículo, e de caráter generalista, os saberes pedagógicos são reconhecidos e institucionalizados.

Já o que acontece nas décadas subseqüentes caminha na direção de uma valorização do tecnicismo nos currículos da educação básica e da valorização, também, dos aspectos técnicos ligados aos fazeres do professor.

É possível traçar um paralelo entre currículos das licenciaturas, especificamente no modelo " $3+1$ ", com as concepções curriculares presentes no Brasil, resultantes da proliferação das ideias tecnicistas.

A escola básica passa um período significativo de tempo regida por currículos enciclopédicos prescritos rigidamente e visando atender a padrões de eficiência no ensino de conhecimentos universais.

A formação de professores também vive um período significativo no qual a racionalidade técnica se faz preponderante, e no qual os conteúdos de ensino são definidos pelos meios acadêmicos disciplinares, sofrendo grande influência das sociedades científicas. 
A partir dos anos oitenta, proliferam-se intensos debates na área de educação. A necessidade de mudanças é reconhecida na escola básica e novos aportes teóricos passam a compor o cenário.

As políticas vigentes para o ensino médio nos anos noventa irão tentar modificar seu caráter propedêutico e conteudista, encarando-o como uma etapa que deve completar a educação básica e preparar o sujeito para o mundo do trabalho e para a cidadania. Nesse sentido, se fazem necessárias também mudanças nos cursos de licenciatura, de maneira que o professor seja formado para atender a essa demanda. As "diretrizes curriculares para formação de professores da educação básica" de 2002 corroboram essa necessidade.

E é na interface entre o ensino de ciências, os pressupostos educacionais mais amplos e a formação de professores, que podemos situar em parte, a Pesquisa em Ensino de Ciências. E isso porque entendemos que a pesquisa e a produção de conhecimento têm um papel importante na consolidação de tendências e nos movimentos de mudança, como argumentaremos na sequência do trabalho. 


\section{CAPÍTULO 5}

\section{A Pesquisa em Ensino de Ciências e a Formação de Professores}

Querem que vos ensine o modo de chegar à ciência verdadeira? Aquilo que se sabe, saber que se sabe; aquilo que não se sabe, saber que não se sabe; na verdade é este o saber.

Confúcio

Delimitamos o âmbito da Pesquisa em Ensino de Ciências como um espaço de investigação, também porque ele se encontra em um interessante espaço de interface. Ao mesmo tempo que, como argumentamos no capítulo quatro, esse campo se relaciona de alguma forma com o Ensino de Ciências e portanto com a escola básica, uma boa parte de suas pesquisas tem íntima relação com a área da formação de professores.

Nas últimas décadas, as investigações específicas sobre ensino de ciências criaram metodologias próprias e elegeram autores de referência, constituindo e delimitando uma área de pesquisa relativamente autônoma.

Entendendo que o conhecimento dessa área é ao mesmo tempo influenciado e influenciador das políticas e das práticas educacionais nos debruçaremos sobre esse campo de pesquisa com vistas às pesquisas que permeiam a licenciatura.

Dadas a afinidade do recorte por nós observado com a área da formação de professores, nosso aporte de investigação nesse capítulo reflete muito das premissas discutidas no capítulo dois. Nesse sentido voltaremos nossos olhares à questão dos saberes docentes, novamente procurando mapear a questão dos "saberes específicos" e dos "saberes pedagógicos" do professor atentos as concepções docentes subjacentes às 
pesquisas analisadas.

Apresentaremos então, nesse capítulo, uma investigação que prioriza o ponto de vista da área de pesquisa em Ensino de Ciências. Em específico, nos debruçaremos sobre pesquisas contidas em um período de tempo delimitado pela repercussão das "Novas Diretrizes Curriculares para Formação de Professores da Educação Básica".

Desenvolveremos essa etapa da pesquisa tendo como objeto de análise as atas dos principais eventos da área. Optamos pelas atas de eventos em detrimento de artigos de periódicos buscando uma correlação temporal mais estreita com o período de repercussão das "Novas Diretrizes Curriculares para Formação de Professores da Educação Básica". Como os artigos de periódicos em geral exigem um tempo maior para publicação, nossa escolha pelos trabalhos publicados em atas de eventos se justifica na potencialidade de que sejam um retrato mais fiel do momento demarcado pelo contexto da repercussão desses documentos oficiais.

Nos propomos a investigar nessa etapa como a área de pesquisa em ensino de ciências tem se debruçado sobre as questões que envolvem a licenciatura em física. Nossa tentativa é a de mapear em que formatos e perspectivas os saberes do professor e as finalidades de um curso de licenciatura aparecem nas pesquisas, nesse período marcado por mudanças.

Optamos então por fazer um levantamento e análise bibliográfica dos trabalhos apresentados em EPEFs (Encontro de Pesquisa em Ensino de Física) e ENPEC's (Encontro Nacional de Pesquisa em Educação em Ciências), no período de 2004 a 2009 especialmente pelo caráter dinâmico da produção nesses eventos.

Acreditamos ser importante identificar como essas questões vêm repercutindo na área no período subseqüente à publicação de novos documentos oficiais e alinhado com os prazos que foram estipulados nesses mesmos documentos para a adaptação dos cursos de licenciatura.

\subsection{Estratégia de Investigação}

Para investigar e situar as questões presentes nas pesquisas em Ensino de Física que, de alguma forma, permeiam as discussões sobre a 
Licenciatura em Física, e que passam a constituir nosso objeto de análise, realizamos uma seleção de artigos nos anais do IX EPEF (2004), V ENPEC (2005), X EPEF (2006), VI ENPEC (2007), XI EPEF (2008) e VII ENPEC (2009).

A identificação dos trabalhos que viriam a compor nosso universo de análise foi feita a partir de uma leitura preliminar dos resumos constantes das atas. Além daqueles trabalhos explicitamente agrupados na área temática de "formação de professores", que tratam da formação inicial, foram também incluídos trabalhos apresentados em outras áreas temáticas (como ensino-aprendizagem, ensino superior, história e filosofia da ciência), mas que de alguma maneira envolvem a licenciatura em Física.

O conjunto selecionado para análise totalizou 171 trabalhos, e a relação completa dos mesmos, constando de título e autores, está apresentada no ANEXO A. A numeração indicada nesse anexo será aquela adotada para as citações dos mesmos ao longo desse capítulo.

Em uma primeira etapa da investigação, procedeu-se, após uma pré-leitura, à identificação, em cada trabalho da amostra, de algumas características específicas, de tal forma a construir um panorama geral abrangente.

Com o intuito de identificar possíveis reflexos decorrentes das novas diretrizes para a formação de professores na pesquisa em Ensino de Física, especificamente no que concerne aos saberes do professor, delimitamos, em nossa análise, quatro aspectos complementares.

Esses aspectos consistem na análise do envolvimento do trabalho quanto à formação inicial de professores; quanto aos sujeitos pesquisados; quanto ao núcleo-foco de atenção do trabalho quanto à formação do licenciando; e, se existente, quanto à concepção de professor privilegiada na pesquisa.

Dada a insuficiência dessa etapa, para identificação dos espaços ocupados pelos saberes do professor e principalmente para identificar como eles se relacionam, elaboramos uma segunda etapa de análise.

Nessa segunda etapa, buscamos identificar, a partir desses elementos iniciais definidos na primeira etapa, a possibilidade de sistematizá- 
los através de alguns perfis de pesquisa que, de certa forma, também sinalizam possíveis tendências da área.

Em ambas as etapas, para a leitura e análise dos artigos selecionados, foi utilizada a Análise de Conteúdo (BARDIN, 2008). Na primeira etapa, as categorias foram estabelecidas por comparação ao longo da análise dos diferentes itens, em um procedimento denominado, por essa autora, de processo de acervo. Na segunda etapa, para a identificação dos perfis, as características das categorias identificadas anteriormente foram reagrupadas em um arranjo que buscava compreender qual a relação que se estabelece (ou não) entre os saberes específicos e pedagógicos do professor, bem como a relação desses saberes com a finalidade de um curso de licenciatura.

\subsection{Um Panorama das Pesquisas e a Licenciatura em Física}

A primeira etapa da pesquisa visando à construção de um panorama geral abrangente se deu pela análise de quatro aspectos complementares.

O primeiro aspecto refere-se à finalidade do trabalho, onde buscaremos indícios sobre o nível de envolvimento do trabalho com a questão da formação inicial de professores. Propomo-nos a observar se o trabalho tem suas preocupações centrais ligadas à "Formação Inicial de Professores" de fato, ou se o curso de Licenciatura apenas constitui para a pesquisa, local privilegiado para investigação de outros aspectos.

Complementarmente, procuramos, nos trabalhos analisados, identificar os sujeitos pesquisados. Com isso, pretendemos ter um indicativo de para onde se voltam os olhos das pesquisas, verificando em que medida a finalidade da pesquisa e a relação entre os saberes se reflete nas escolhas feitas.

Uma comparação entre os trabalhos apontou a necessidade de mais um item a ser observado: núcleo-foco de atenção quanto à formação do licenciando. Ficou bastante evidente a existência de dois grupos de pesquisas bem distintos em relação ao aspecto formativo. Um conjunto de trabalhos volta seus olhares para a dinâmica do ensino-aprendizagem, para os conhecimentos que orientarão a prática do futuro professor, seja essa a transposição dos conhecimentos de física para o ensino médio, ou as 
estratégias de ensino, e etc.. Esse conjunto foi por nós denominado de foco de atenção ou núcleo pedagógico. Existe ainda um outro conjunto que tem seu foco voltado ao ensino-aprendizagem dos conceitos de física em si, nos cursos de licenciatura, que denominamos de foco de atenção ou núcleo Física.

O último aspecto que analisamos, a fim de dar mais um indício comparativo e complementar aos anteriores, refere-se à existência ou não de uma concepção de professor explicitamente privilegiada na pesquisa. Isso por si só, nada garante a respeito do perfil do trabalho, mas como aspecto complementar, combinado à análise de quem é o sujeito pesquisado e de qual o foco de atenção da pesquisa, nos dá novos indícios sobre a relação entre os saberes do professor.

Podemos assim sistematizar os aspectos a serem investigados, que referem-se, respectivamente,

- ao envolvimento do trabalho quanto à formação inicial de professores

- a sujeitos pesquisados

- ao núcleo-foco de atenção de atenção do trabalho quanto a formação do licenciando

- a concepção de professor privilegiada

5.2.1 Envolvimento do trabalho quanto à formação inicial de professores

Nessa etapa procuramos identificar quais dos trabalhos de fato estão focados de alguma maneira na problemática da formação inicial de professores. Isso porque uma primeira análise mostrou que, dentre pesquisas que permeiam de alguma forma a licenciatura, existem os trabalhos que, de fato demonstram preocupação explícita com a questão da formação inicial, e outros em que o curso ou os alunos da licenciatura se apresentam como lócus privilegiado para responder questões de pesquisa de outra natureza. A figura 5.1 apresenta essa sistematização em números absolutos.

Embora a maioria dos trabalhos tenha como preocupação central a formação inicial de professores e/ou a questão dos saberes docentes, há uma quantidade considerável de trabalhos que, apesar de ter 
relação com a licenciatura, não apresenta qualquer particularidade, em relação ao fato de estar em contato com futuros professores.

Essa classificação, combinada com outros elementos que serão explorados adiante na análise, nos dará importantes indícios sobre o perfil dos trabalhos.

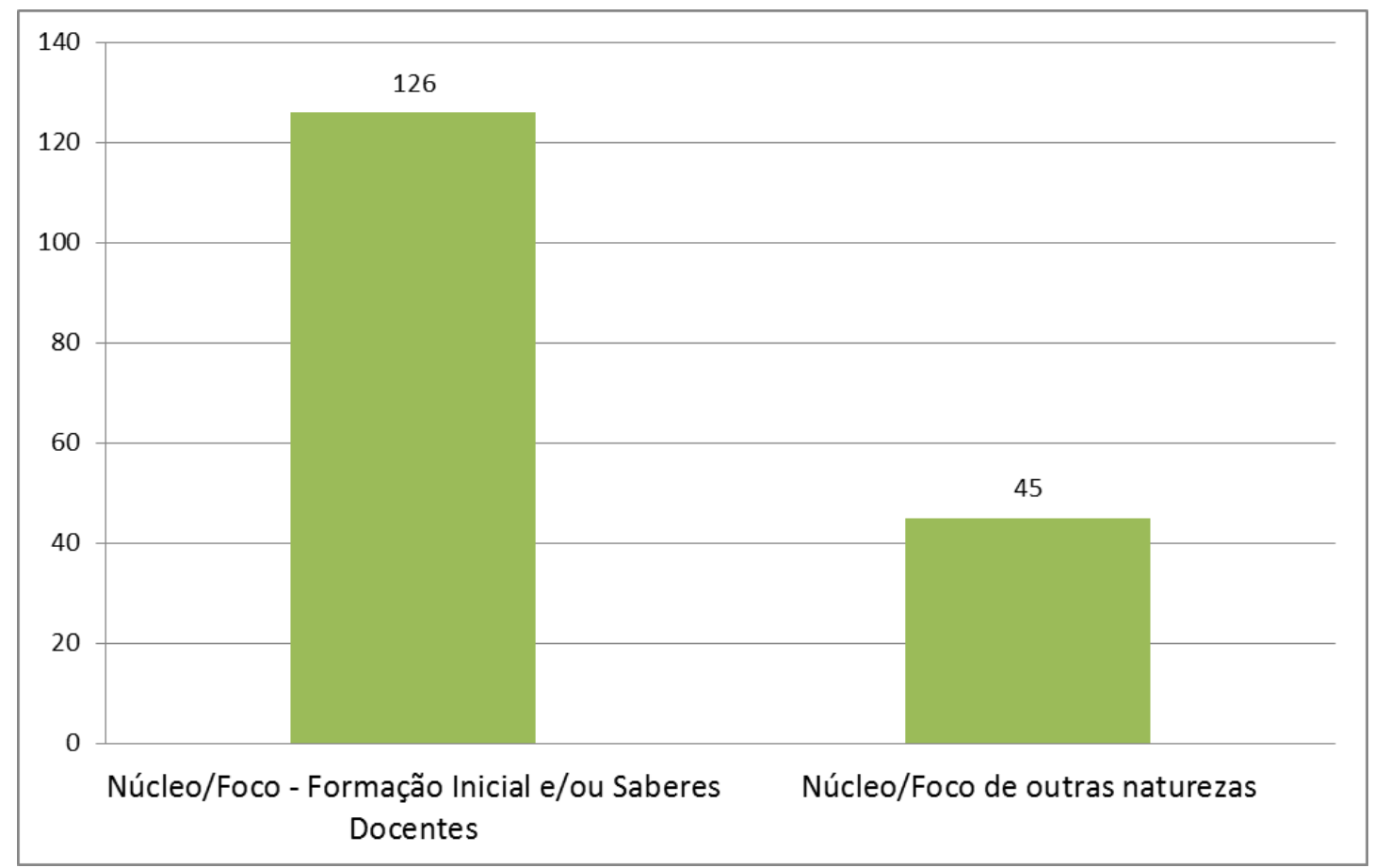

Figura 5. 1 - Envolvimento do trabalho quanto à formação inicial de professores

\subsubsection{Sujeitos pesquisados}

Quanto aos sujeitos pesquisados, ou seja, aos sujeitos foco de atenção em cada um dos trabalhos analisados, foram identificadas algumas categorias, a partir da própria explicitação realizada pelos autores. Em alguns casos, contudo, como em trabalhos com ênfase mais teórica, esse aspecto assume um caráter mais geral. As categorias estabelecidas são:

a) Alunos de prática de ensino

b) Alunos de disciplinas pedagógicas (DP) que não a prática de ensino (instrumentação para o ensino, metodologia do ensino, oficinas e etc.)

c) Alunos de disciplinas de Física (DF)

d) Professores Universitários

e) Alunos da Licenciatura (sem distinção de disciplinas) 
f) Outros (técnicos de laboratório, recém formados, alunos do EM )

g) Sujeito genérico (pesquisas teóricas)

O resultado da freqüência de trabalhos nessas categorias está apresentado na Figura 5.2, permitindo verificar a distribuição dos trabalhos por sujeito pesquisado. (Alguns trabalhos apresentam mais de um tipo de sujeito pesquisado, e podem estar incluídos em mais de uma categoria).

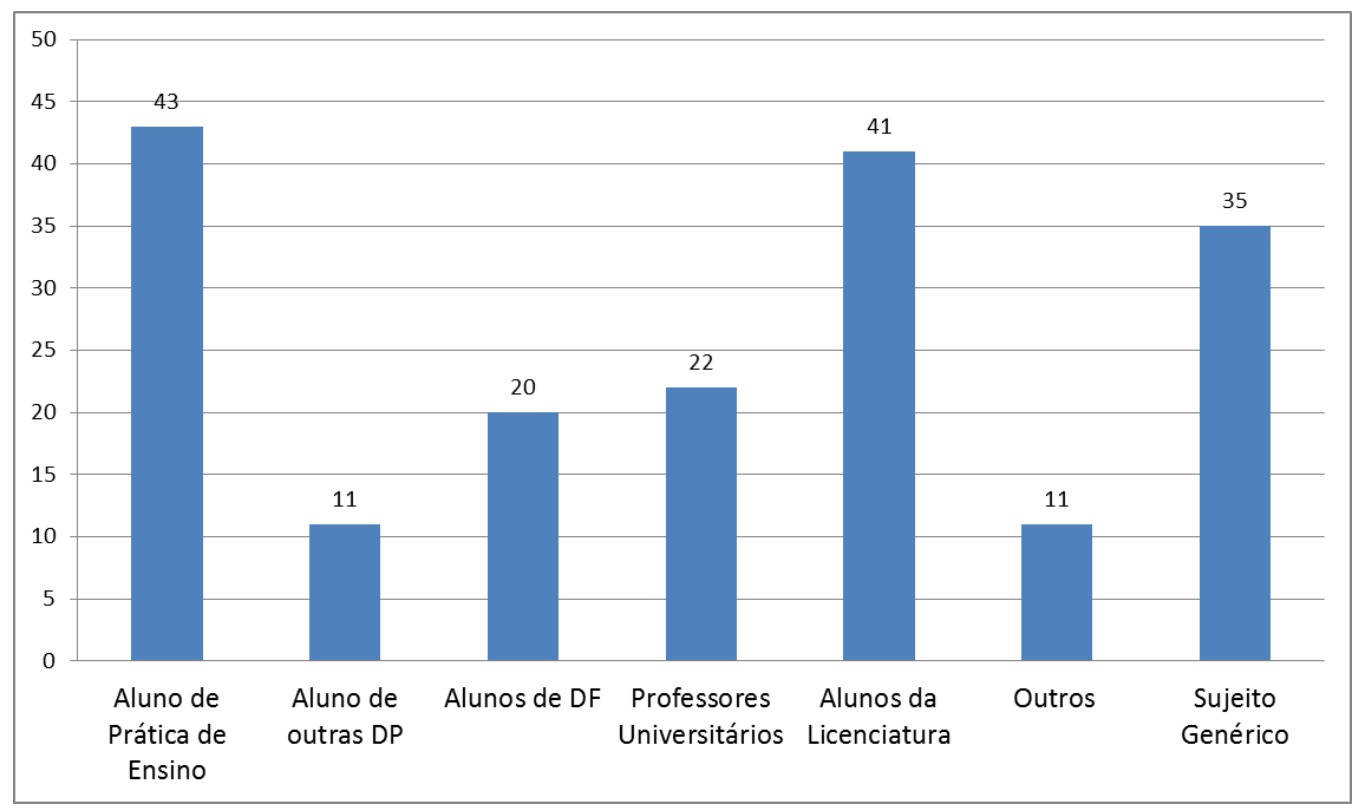

Figura 5. 2 - distribuição dos trabalhos por sujeito pesquisado

Observamos, a partir desses resultados, que dos 183 sujeitos identificados nos trabalhos analisados, 43 correspondem a "Alunos de Prática de Ensino", e esse é, portanto, o maior grupo identificado. Se ainda somarmos esse número aos 11 trabalhos onde o sujeito da pesquisa é o "Aluno de outra DP" temos aí uma parcela considerável. Isso significa que um terço desses trabalhos ocupa-se de sujeitos na perspectiva dos "Saberes Pedagógicos", e isso delimita um espaço interessante.

Os trabalhos que pesquisam alunos de "Disciplinas de Física" nos dão indício de que, há também, um espaço ocupado pelos "Saberes Especificos".

Uma parcela considerável dos trabalhos encontra-se no grupo no qual os "Alunos da Licenciatura" são sujeitos das pesquisas. Para compreender mais a fundo o que esse dado pode nos indicar, é preciso ir adiante na investigação dos outros aspectos.

Também precisaríamos combinar outros indicativos para tirar 
conclusões sobre o grupo dos "Professores Universitários", "Outros", e sobre o "Sujeito Genérico".

\subsubsection{Núcleo-foco de atenção 7 do trabalho quanto à formação do licenciando}

Considerando o núcleo-foco de atenção quanto à formação do licenciando, classificamos os trabalhos em pedagógico ou de física, ou ainda ambos. Essas categorias visam aprofundar o entendimento sobre o papel do saber específico dentre os saberes do professor e as relações que estabelece em particular, com os saberes pedagógicos.

Quando o trabalho explicita seu foco na dinâmica do ensinoaprendizagem dos conhecimentos que orientarão a prática do futuro professor, seja essa a transposição dos conhecimentos de física para o ensino médio, as estratégias de ensino, a reflexão sobre a prática, pesquisa na ação e etc. consideramos que ele pertence ao núcleo-foco pedagógico.

Embora, como já discutido no cap. 1, em algumas concepções as ações didáticas que se dêem sobre os conteúdos, explicitando uma relação entre os saberes, entendemos aqui que pertencem ao núcleo-foco pedagógico. Isso porque no cerne dos cursos de formação essas discussão visa a ação pedagógica do licenciando e não a sua formação na área específica, ou seja, sua aprendizagem de física.

Quando o trabalho tem seu foco voltado ao ensinoaprendizagem dos conceitos de física em si, nos cursos de licenciatura, consideramos que ele pertence ao núcleo-foco de física. Seguem os dados sistematizados na Figura 5.3.

Os trabalhos cuja preocupação central refere-se a aspectos da aprendizagem de física em si, na formação de professores, representam 36\% do total. Os trabalhos que discutem aspectos da formação do aluno enquanto futuro professor representam 51\% do total. Assim, uma pequena parcela constitui os trabalhos que apresentam aspectos em ambos os núcleos, e que serão discutidos de maneira mais detalhada adiante. Por hora podemos perceber que é predominante a tendência de tratar esses núcleos de forma distinta. 


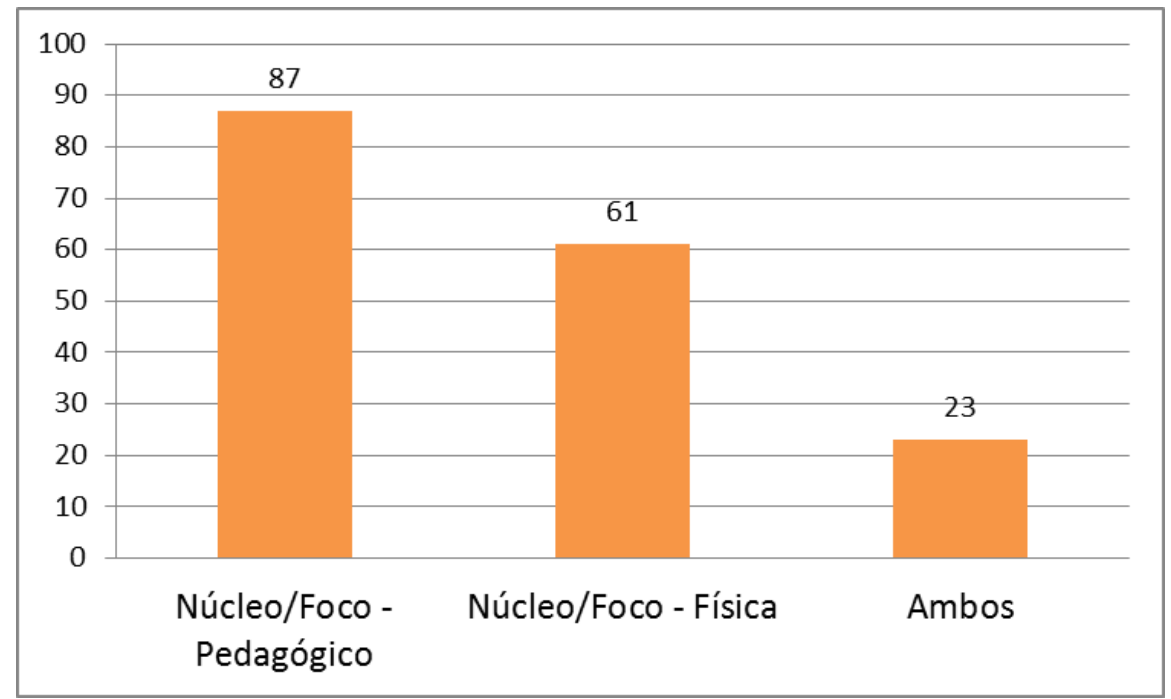

Figura 5. 3 - Núcleo-foco de atenção do trabalho quanto à formação do licenciando

\subsubsection{Concepção de professor explicitamente privilegiada}

No que diz respeito à concepção de professor citada nos trabalhos analisados, que foi o quarto aspecto abordado, criamos categorias de análise que, em parte, refletem o percurso apresentado no capítulo dois.

Não se trata de uma correspondência, pois no capítulo dois explicitamos um agrupamento de autores e perspectivas que se propunha a responder como se coloca a questão dos saberes docentes e em especial do saberes específicos disciplinares nesses paradigmas. A definição dos paradigmas apresentados foi inspirado fortemente na obra de Contreras (2002).

Nesse momento retrataremos como a pesquisa em Ensino de Ciências faz uso desses autores e perspectivas, e, portanto, o agrupamento não é exatamente o mesmo. No entanto, reconhecemos na obra de Contreras (2002) uma importante contribuição no que concerne a organização das concepções existentes sobre os professores. Nesse sentido a categorização aqui presente é uma amálgama que tenta se utilizar da sistematização de Contreras e ao mesmo tempo respeitar o uso que é feito, dos autores e concepções, pela área de Ensino de Ciências.

As categorias que construímos são: 
- "Saberes da Prática" - são os trabalhos que se apóiam no paradigma da prática, ressaltando a importância dos saberes produzidos pelos professores durante o fazer em sala de aula, por meio da reflexão. Expressões como professor-pesquisador, professor-reflexivo, reflexão na ação aparecem em alguns desses trabalhos. São autores de referência citados : Tardif, Schön, Nóvoa, Perrenoud, Carvalho e Gil Pérez, Porlán, Pimenta e outros.

- "Didática Específica" - agrupa os trabalhos que fazem referência à importância da transposição didática dos conteúdos, ao Conhecimento Pedagógico do Conteúdo e destacam aspectos metodológicos específicos. São autores de referência citados, Shulman, Chevalard, Carvalho e Gil Pérez, entre outros.

- "Crítica" - agrupa os trabalhos que apresentam discussões sobre o papel dos saberes do professor na perspectiva de transformação, emancipação e da conscientização crítica. São autores de referência citados, Freire, Giroux, Bordieu, Contreras, Carr \& Kemmis e outros.

Além disso, e tão relevante quanto a concepção adotada, pudemos identificar aqueles trabalhos que não mencionam de forma explícita nenhuma concepção de professor.

É preciso ressaltar que mencionar uma dada ênfase não significa incorporá-la. Apropriamo-nos de um indício indireto, que é a bibliografia citada, e tentamos ainda identificar termos, expressões e argumentos explícitos apresentados no trabalho. No entanto, não nos propomos a nenhum tipo de análise comparativa das interpretações e tratamentos diferenciados dados aos termos e significados a eles atribuídos.

\footnotetext{
5 A categoria "didática específica" é a que menos reflete o modo como as concepções foram apresentadas no capítulo dois. Numa tentativa de correspondência, diríamos que alguns trabalhos refletem mais as técnicas de ensino ligadas ao conhecimento físico, mas em muitos trabalhos também é possível identificar valores que transcendem a racionalidade técnica.
} 
Nosso interesse é, apenas, identificar em que medida a preocupação com a própria questão da concepção de professor a ser formado está ou não presente nos trabalhos analisados.

Os resultados da análise que fizemos seguem sistematizados na Figura 5.4. Há trabalhos que citam simultaneamente mais de uma concepção de professor e estão computados em mais de uma coluna. Os trabalhos classificados por categoria de concepção de professor se encontram no anexo $\mathrm{E}$.

Podemos perceber que há uma grande parcela dos trabalhos que não mencionam de forma explícita concepção alguma de professor (82 trabalhos em 171), o que representa cerca de $48 \%$ do conjunto analisado. Isso nos mostra a importância de diferenciar, na análise, os aspectos núcleo/foco de atenção com a formação inicial, e a menção a uma concepção de professor. Como veremos adiante, há um número significativo de trabalhos que apresenta de alguma forma, preocupação com a formação inicial de professores, mas não delimita o que é o "ser/formar professor" em sua visão.

Dentre os trabalhos que tem concepção explícita, observamos que a concepção predominante é do paradigma da prática, que remontam o maior grupo, somando 45 trabalhos. São ainda 36 trabalhos que se encaixam e/ou na perspectiva crítica e 24 trabalhos que se encaixam e/ou na perspectiva da didática específica.

Podemos perceber que o paradigma dos saberes da prática, como tentativa de superação da racionalidade técnica, tem atualmente um grande apelo. Isso poderia ser interpretado como um indício de que a superação de fato ocorre, porém, ao combinar esses dados com a análise dos outros aspectos, veremos que isso é predominantemente circunscrito a certos grupos.

Temos, assim, a análise de 171 trabalhos, que foram classificados segundo os quatro aspectos complementares. Essa análise não se mostrou suficiente, principalmente no que concerne a entender as relações entre os saberes do professor. Assim sendo, fizemos o cruzamento dos dados obtidos na primeira etapa tentando delimitar perfis de pesquisa. 


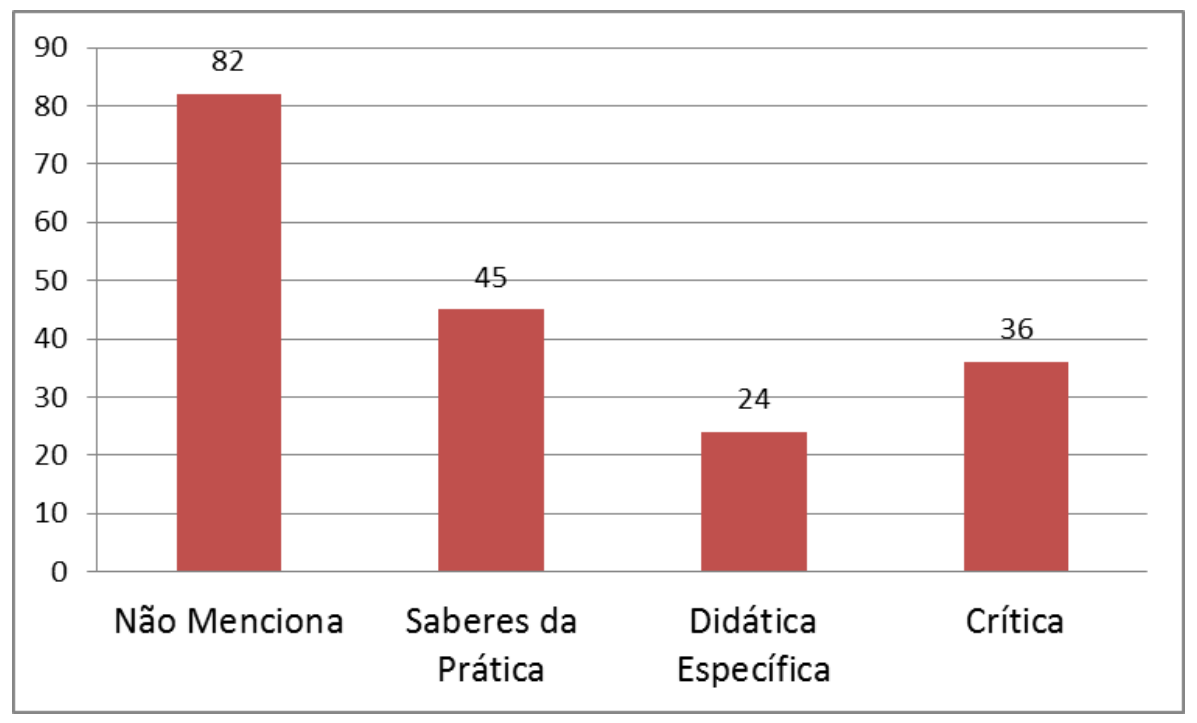

Figura 5.4 - Concepção de professor explicitamente privilegiada

\subsection{Identificação de Perfis de Pesquisa}

Buscamos, nessa segunda etapa, identificar, a partir da articulação entre os aspectos indicados anteriormente, ou seja, os sujeitos pesquisados, envolvimento quanto à formação de professores, núcleo-foco de atenção quanto à formação do licenciando e concepção de professor privilegiada, alguns perfis ou tendências com maior incidência nas pesquisas desenvolvidas na área.

Delimitamos 7 perfis de pesquisa que seguem sistematizados na tabela 5.1:

\begin{tabular}{lccc}
\hline & $\begin{array}{c}\text { Envolvimento com a } \\
\text { formação de } \\
\text { professores }\end{array}$ & $\begin{array}{c}\text { Núcleo/foco } \\
\text { formativo }\end{array}$ & $\begin{array}{c}\text { Concepção } \\
\text { de professor }\end{array}$ \\
\hline Perfil 1 & NÃO & FíSICA & NÃO \\
\hline Perfil 2 & NÃO & PEDAGÓGICO & NÃO \\
\hline Perfil 3 & SIM & PEDAGÓGICO & NÃO \\
\hline Perfil 4 & SIM & PEDAGÓGICO & SIM \\
\hline Perfil 5 & SIM & FíSICA & SIM \\
\hline
\end{tabular}




\begin{tabular}{|c|c|c|c|}
\hline Perfil 6 & SIM & FÍSICA & NÃO \\
\hline Perfil 7 & $\mathrm{Am}$ & Focos de & \\
\hline
\end{tabular}

Tabela 5. 1 - Perfis de Pesquisa

No Perfil 1, temos os trabalhos sem envolvimento na formação de professores, voltados para o núcleo de Física quanto à formação do licenciando, sem explicitação de concepção de professor.

No Perfil 2, temos os trabalhos sem envolvimento na formação de professores, voltados para o núcleo pedagógico quanto à formação do licenciando, sem explicitação de concepção de professor.

No Perfil 3, temos os trabalhos com envolvimento na formação de professores, voltados para o núcleo pedagógico quanto à formação do licenciando, sem explicitação de concepção de professor.

No Perfil 4, temos os trabalhos com envolvimento na formação de professores, voltados para o núcleo pedagógico quanto à formação do licenciando, com explicitação de concepção de professor.

No Perfil 5, temos trabalhos com envolvimento na formação de professores, voltados para o núcleo física quanto à formação do licenciando, com explicitação de concepção de professor.

No Perfil 6, temos os trabalhos com envolvimento na formação de professores, voltados para a física quanto à formação do licenciando, sem explicitação de concepção de professor.

E finalmente no Perfil 7 , temos os trabalhos que pertencem tanto ao núcleo física, quanto ao núcleo pedagógico quanto ao aspecto formativo. Esses trabalhos possuem uma natureza diferenciada, e serão discutidos em detalhes mais adiante. Por hora não se mostra relevante classificá-los nos outros aspectos.

Definidos os perfis, é possível então, fazer uma distribuição dos trabalhos analisados. Na tabela 5.2 trazemos essa análise em números absolutos, e na Figura 5.5, uma representação de distribuição percentual. (Segue no Anexo B a classificação detalhada dos trabalhos por perfil). Um resumo das características gerais dos trabalhos de cada Perfil se encontra na tabela 5.3. 


\begin{tabular}{|c|c|c|c|}
\hline Perfil & Descrição & & $\begin{array}{l}\text { os no } \\
\text { fil }\end{array}$ \\
\hline Perfil 1 & $\begin{array}{l}\text { Trabalho sem envolvimento na tormação de protessores, } \\
\text { voltados para a física quanto a formação do licenciando, sem } \\
\text { explicitação de concepção de professor }\end{array}$ & 39 & $23 \%$ \\
\hline Perfil 2 & $\begin{array}{l}\text { Trabalho sem envolvimento na formação de professores, } \\
\text { voltados para o núcleo pedagógico quanto a formação do } \\
\text { licenciando, sem explicitação de concepção de professor }\end{array}$ & 4 & $2 \%$ \\
\hline Perfil 3 & $\begin{array}{l}\text { Trabalho com envolvimento na formação de professores, } \\
\text { voltados para o núcleo pedagógico quanto a formação do } \\
\text { licenciando, sem explicitação de concepção de professor }\end{array}$ & 17 & $10 \%$ \\
\hline Perfil 4 & $\begin{array}{l}\text { Trabalho com envolvimento na formação de professores, } \\
\text { voltados para o núcleo pedagógico quanto a formação do } \\
\text { licenciando, com explicitação de concepção de professor }\end{array}$ & 66 & $39 \%$ \\
\hline Perfil 5 & $\begin{array}{l}\text { Trabalho com envolvimento na formação de professores, } \\
\text { voltados para o núcleo física quanto a formação do licenciando, } \\
\text { com explicitação de concepção de professor }\end{array}$ & 3 & $2 \%$ \\
\hline Perfil 6 & $\begin{array}{l}\text { Trabalho com envolvimento na formação de professores, } \\
\text { voltados para a física quanto a formação do licenciando, sem } \\
\text { explicitação de concepção de professor }\end{array}$ & 19 & $11 \%$ \\
\hline Perfil 7 & Pertencentes ao Núcleo Físico e Pedagógico & 23 & $13 \%$ \\
\hline
\end{tabular}

Tabela 5. 2 - tabela de números absolutos de trabalhos por perfil

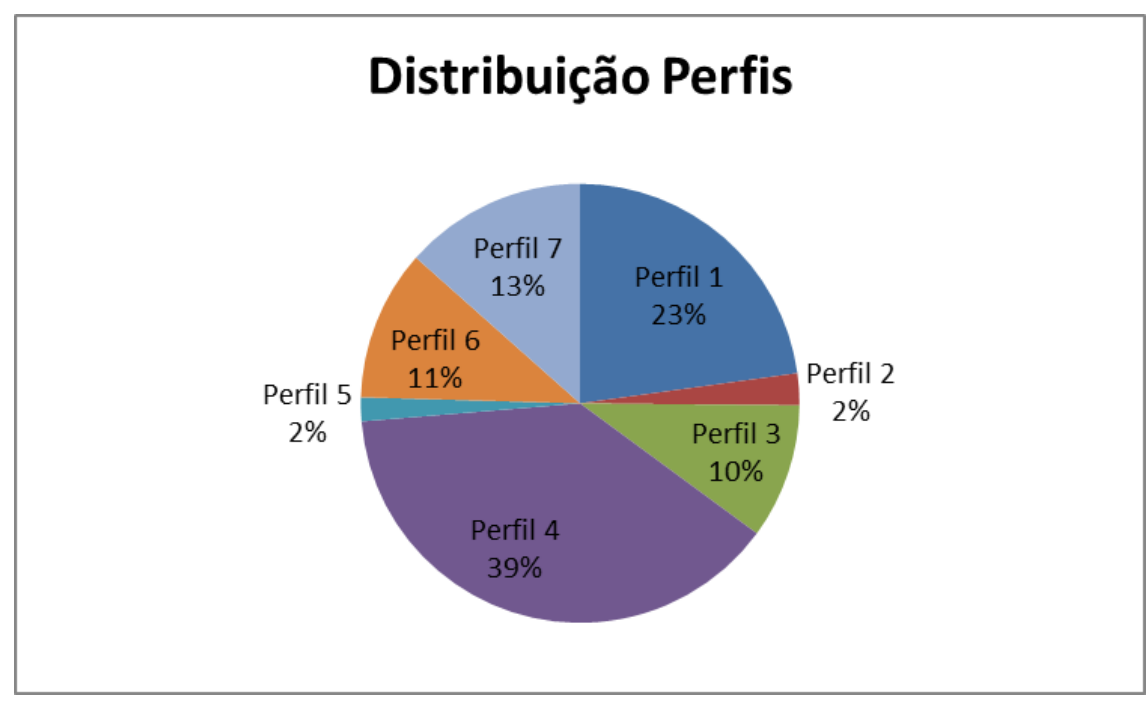

Figura 5.5 - distribuição de Perfis 
Sem envolvimento com a formação de

professores, voltado para a formação

em física sem explicitação de

concepção de professor

Sem envolvimento com a formação de professores e sem explicitação de concepção de professor

Voltado para a formação pedagógica

Perfil 3 do licenciando sem explicitação de concepção de professor

Voltado para a formação pedagógica

Perfil 4 do licenciando com explicitação de concepção de professor

\begin{tabular}{cc}
\hline Perfil 5 & $\begin{array}{c}\text { Voltados para a formação em física } \\
\text { com explicitação de concepção de } \\
\text { professor }\end{array}$ \\
\hline Perfil 6 & $\begin{array}{c}\text { Voltados para a formação em física } \\
\text { sem explicitação de concepção de } \\
\text { professor }\end{array}$ \\
Perfil 7 & Pertencentes ao Núcleo Físico e \\
Pedagógico
\end{tabular}

Pedagógico
São trabalhos voltados ao Ensino de Física no Ensino Superior, em interface com os cursos de licenciatura, mas que não expressam qualquer menção ao fato que se está ensinado física para futuros professores.
São trabalhos diversos, que pretendem pesquisar algo em específico, referente as aspectos pedagógicos, como ensino aprendizagem, uso de tecnologias da informação e comunicação, e etc, que tem interface com cursos de licenciatura, mas não fazem nenhuma menção a formação de professores especificamente.

São trabalhos diversos, que pretendem pesquisar algo em específico, referente as aspectos pedagógicos, como ensino aprendizagem, uso de tecnologias da informação e comunicação, e etc, que tem interface com cursos de licenciatura, e têm alguma preocupação específica e/ou pretendem dar alguma contribuição a formação de professores, porém se aprofundar na questão, nem demonstra ter uma concepção explícita de professor

São trabalhos que de fato expressam como tema central a questão da formação de professores, se debruçam sobre a questão, estabelecendo uma concepção de professor, em geral fundamentada em referenciais teóricos da área de formação de professores. Se debruçam sobre questões pedagógicas, como a metodologia específica do ensino de física, a transposição didática dos conteúdos de física para o EM, a construção da identidade na prática e etc.

São todos trabalhos com interface a área História e Filosofia da ciência que discutem a importância do ensino da
Física nessa perspectiva, nos cursos de licenciatura, relacionado com uma concepção de professor fundamentada em literatura pertinente.

São trabalhos que tem centralmente uma preocupação com o ensino da física na licenciatura, e com as implicações desse ensino, pelo fato de serem futuros professores, porém, não discute explicitamente o que é ser professor em sua concepção.

São trabalhos sobre: Currículo, evasão, pesquisa sobre a perspectiva dos alunos, estudo de caso de prof. recém formado, analise do histórico dos cursos, revisões bibliográficas sobre formação de professores, perspectivas dos professores universitários, reflexões teóricas sobre os modelos de formação docente 
Uma análise dessa distribuição nos leva a observar que a maioria das pesquisas realizadas, nesse período, corresponde ao que denominamos de Perfil 4. Percebemos, assim, que há uma tendência de fundamentação teórica dentro do grupo de trabalhos pertencentes ao núcleo pedagógico quanto à formação, pois muitas pesquisas mencionam claramente uma concepção de professor, e fundamentam-se em referenciais predominantes. Dos trabalhos pertencentes a esse perfil, podemos destacar 35 que mencionam os "saberes da prática", 18 que categorizamos na "didática específica" e 23 que categorizamos na perspectiva "crítica" 6 . Isso pressupõe que há um movimento de incorporação dos saberes da prática e, portanto, um movimento que vai na direção da superação do paradigma da racionalidade técnica, pelo menos no que diz respeito ao núcleo/foco pedagógico da formação.

Podemos ainda fazer uma relação desse perfil com o segundo aspecto analisado que trata do sujeito pesquisado. Dos trabalhos pertencentes ao Perfil 4, 50 \% dos sujeitos pesquisados são alunos de prática de ensino, $12 \%$ alunos de outras DP e $17 \%$ são pesquisas com sujeito genérico.

Isso nos indica a existência de um grupo considerável de pesquisas com uma característica comum. São pesquisas realizadas com alunos das disciplinas pedagógicas que visam a formação do licenciando em suas habilidades pedagógicas (com a dinâmica do ensino-aprendizagem, dos conhecimentos que orientarão a prática do futuro professor, seja essa a transposição do conhecimento de física para o ensino médio, ou as estratégias de ensino, e etc) e citam uma concepção de professor. E dentre essas concepções predomina o paradigma da prática.

Outro fato que chama atenção, na análise dos perfis das pesquisas, é que o segundo maior grupo de pesquisas, o Perfil 1, é aquele que se refere ao ensino da física propriamente dito, sem fazer nenhuma menção à concepção de formação de professores, nem explicitar preocupação com isso. Temos aqui um grupo de pesquisas que aparentemente fica apartado do conhecimento produzido sobre formação de professores.

Para aprofundar a análise do Perfil 1, fazendo sua relação

\footnotetext{
${ }^{6}$ No que concerne aos saberes docentes um mesmo trabalho pode estar em mais uma categoria
} 
com os sujeitos pesquisados, percebemos que $37 \%$ dos trabalhos pesquisam alunos de disciplinas de física, $12 \%$ pesquisam professores universitários e $34 \%$ pesquisam alunos da licenciatura como um todo. Isso nos indica a predominância de um outro olhar, onde há interesses de pesquisa dos mais diversos, e os alunos e professores da licenciatura formam apenas o lócus dessas pesquisas.

Há outro grupo de trabalhos, que na verdade se trata de um perfil intermediário, o Perfil 6. Esse grupo de trabalhos está predominante preocupado com o ensino da física na formação do licenciando, e explicita algum tipo de preocupação com o fato de estar tratando da formação de futuros professores, mas não aprofunda a questão do professor em si, ou seja, não traz nenhuma concepção de professor em seu discurso. Muitos dos trabalhos nesse âmbito, ao falar sobre o ser professor e seus saberes, beiram o senso comum a respeito.

Outro ponto que nos chama a atenção é o reduzido número de trabalhos no Perfil 5 (apenas três) que, estando no núcleo/foco da formação de física do sujeito, têm preocupação com o fato de estar ensinando física para futuros professores, e busca incorporar alguma fundamentação a respeito, citando literatura pertinente à área de formação de professores.

Todos os trabalhos pertencentes ao Perfil 5 são trabalhos que defendem e fundamentam a inclusão da História e da Filosofia da Ciência na formação de professores.

No Perfil $348 \%$ dos sujeitos pesquisados são alunos de Prática de Ensino, 10\% são professores universitários e 14\% são alunos da licenciatura como um todo. Esses trabalhos tem características muitas vezes semelhantes aos caracterizados no perfil 4, apenas se diferenciando por não citar de forma explícita uma concepção de professor.

O Perfil 2 representa um pequeno grupo de trabalhos (apenas 4), que se situa no núcleo-foco pedagógico e de alguma forma permeia os cursos de formação, mas não tem preocupação direta com a formação de professores. São trabalhos que apenas usam como lócus privilegiado os cursos de formação para pesquisar os mais diversos aspectos, como concepções de ensino aprendizagem e etc.

O Perfil 7 é um grupo que merece ser analisado mais de perto 
para levar em conta suas especificidades.

Num primeiro subgrupo do perfil 7 podemos identificar onze trabalhos que, de alguma forma, permeiam o assunto currículo (trabalhos: $14,17,44,45,73,74,83,97,119,145,161)$. Oito desses trabalhos analisam a reestruturação do projeto pedagógico de um curso de licenciatura para se adequar às "Novas Diretrizes Curriculares para a Formação de Professores". Dois deles apresentam pesquisas históricas da evolução de cursos de licenciatura. Há, ainda, um trabalho que apresenta as bases teóricas de uma proposta curricular de um curso de licenciatura ainda não implementado, em sintonia com as exigências das "Novas Diretrizes Curriculares para a Formação de Professores".

O outro subgrupo identificado no perfil 7 é constituído de sete trabalhos que são levantamentos e análise de opiniões de alunos e professores dos cursos de licenciatura, e se debruçam sobre problemas como a evasão e a baixa procura dos cursos (trabalhos: 18,19,38,120,122,162,168).

No perfil 7, optamos por não classificar os trabalhos do ponto de vista de explicitar ou não uma concepção de professor, pois esse tema permeia de forma diferenciada tanto a temática do currículo quanto as pesquisas de opinião. Podemos, ainda, identificar que são essas duas temáticas que dominam a maioria dos trabalhos classificados simultaneamente como pertencentes ao núcleo/foco de atenção física e núcleo/foco de atenção pedagógico.

Há ainda um pequeno subgrupo do perfil 7, de cinco trabalhos de cunho mais teórico (trabalhos 98, 126, 159, 163, 169), que traz alguma discussão que podemos aproximar do nosso problema de pesquisa pois menciona a existência tanto de saberes específicos quanto de saberes pedagógicos na formação docente. Esses trabalhos serão aprofundados no capítulo seis assim como os trabalhos mais voltados à temática do currículo.

Assim os trabalhos do Perfil 7, pertencem ao núcleo-foco "ambos", não por apresentarem uma forma orgânica de pensar os saberes na formação, mas sim por perpassarem de alguma forma, a existência das duas formas de saber, o "especifico" e "pedagógico" nos cursos de formação. 


\subsection{Considerações sobre a Pesquisa em Ensino de Ciências e a Formação de Professores}

A análise da produção da área de Pesquisa em Ensino de Física, no período e nas condições desenvolvidos, mostrou que existe uma expressiva preocupação com a formação inicial de professores.

Incorporando o aporte construído no capítulo dois tentamos identificar a presença ou não de concepções de professor subjacentes as pesquisas e explicitar possíveis diferenças.

Para identificar a natureza das concepções presentes propusemos o reconhecimento de alguns diferentes perfis de pesquisa, que se distinguem, basicamente, quanto ao núcleo de atenção e quanto à presença (ou não) de uma discussão acerca da concepção do professor que se deseja formar.

No decorrer do trabalho, foi realizada uma extensa análise baseada em diferentes categorias, a partir das quais se buscou estabelecer novas correlações entre as características das pesquisas. É importante ressaltar, contudo, que, embora o procedimento de categorização possa ser, algumas vezes, localmente questionado (pois expressa o ponto de vista dos analistas), o quadro geral que emerge dessa pesquisa, e que baliza essas considerações, é suficientemente amplo para ser sustentado.

$\mathrm{Na}$ busca então por mapear as concepções docentes presentes das pesquisas, buscamos localizar os espaços e formas ocupados pelos "Saberes Pedagógicos" e pelos "Saberes Específicos" assim como fizemos no capítulo dois. E novamente, na busca e no mapeamento dos diferentes saberes nas diferentes concepções docentes encontradas, procuramos levantar limites e possibilidades que contribuam para um retrato capaz de levar em conta a complexidade do quadro em questão.

Pudemos perceber que o "Saber Pedagógico" ocupa um espaço expressivo dentro da área de ensino de ciências e das pesquisas de fato preocupadas com a formação de professores. Por outro lado a grande maioria dos trabalhos que demarcam espaços do "Saber Específico", não apresenta uma reflexão fundamentada sobre a formação docente.

Podemos então sistematizar de que forma os saberes na 
formação são tratados nos diferentes perfis de pesquisa, no que concerne a formação em Física e a Formação Pedagógica, bem como a questão da articulação entre esses núcleos, mostrando que existem lacunas. Essa sistematização segue na tabela 5.4.

Nossos resultados dão fortes indícios de que são predominantes as pesquisas em ensino voltadas à formação pedagógica do licenciando. As pesquisas dessa natureza que são fundamentadas por uma concepção de professor constituem-se em $40 \%$ do total, apresentando uma relativa convergência na preocupação e no tipo de professor que pretendem formar. Além disso, grande parte das pesquisas analisadas (mais de 50\%) enquadra-se em perfis que têm atenção ao núcleo pedagógico.

Já no espaço demarcado pelos "Saberes de Física" vemos com preocupação o fato de que há um grande número de trabalhos pertencentes ao núcleo de Física e que não menciona uma concepção de professor de forma explícita, nem objetivos específicos para formação dos mesmos. Nesse sentido, podemos constatar, que os cursos de Licenciatura apresentam-se, muitas vezes, apenas como o lócus dessas pesquisas e não seu foco.

Incorporando ainda à análise o aporte teórico trazido no capítulo um, vemos indícios de que as disciplinas e os saberes de física se encontram profundamente naturalizados nos currículos. Quase não há pesquisas que os investiguem e questionem. Parece-nos que de fato a pesquisa em ensino de ciências não incorporou a perspectiva curricular crítica, no sentido de encarar o currículo das licenciaturas como uma construção histórico social. Ainda parece prevalecer a concepção de que as disciplinas científicas da física, que existem mais ou menos de acordo com áreas historicamente consolidadas, são a única forma de organização possível. E esses formatos, inclusive, reproduzem a fragmentação dos saberes na sua forma acadêmica, e nada parecem ser influenciados pelas finalidades formativas, ou seja, pelo fato de se estar formando o professor da educação básica. 


\begin{tabular}{|c|c|c|c|}
\hline \multirow{2}{*}{ Perfil de Pesquisa } & \multicolumn{3}{|c|}{ Saberes na Formação } \\
\hline & Formação em Física & Formação Pedagógica & Articulação \\
\hline 1 & $\begin{array}{l}\text { São pesquisas voltadas } \\
\text { ao Ensino de Física no } \\
\text { Ensino Superior sem } \\
\text { preocupação com } \\
\text { finalidades }\end{array}$ & - & - \\
\hline
\end{tabular}

2

A formação pedagógica

é preocupação do

3

trabalho, mas não há

menção à concepção de

professor

\begin{tabular}{cc}
\hline 4 & - \\
& \\
& $\begin{array}{c}\text { São pesquisas voltadas } \\
\text { ao Ensino de Física } \\
\text { levando em conta a } \\
\text { especificidade dos } \\
\text { cursos de licenciatura. }\end{array}$
\end{tabular}

A formação pedagógica

é preocupação central

do trabalho, que

apresenta também uma

concepção docente

fundamentada.

A formação pedagógica está presente quando a física ensinada é problematizada em suas finalidades, baseando-se em uma concepção de professor bem fundamentada.

As pesquisas permeiam a questão da formação pedagógica, mas de forma não

fundamentada
Existe de forma orgânica no pensar o conhecimento físico e seu ensino de forma articulada com a formação pedagógica e que se deseja do futuro professor.
São pesquisas voltadas ao Ensino de Física levando em conta a especificidade dos cursos de licenciatura.

\section{Existe de forma superficial}

\section{Aparece nas temáticas} tratadas
Aparece nas temáticas tratadas

Os trabalhos nesse perfil reconhecem e existência dos dois núcleos de saberes 
Podemos perceber alguma relação mais orgânica entre os "Saberes Específicos" e "Saberes Pedagógicos", no qual a física ensinada parece ter finalidades educativas explicitas, num pequeno grupo de três trabalhos (Perfil 5).

Percebemos, também, que esses únicos trabalhos voltados ao núcleo de Física dos cursos de licenciatura, que explicitam alguma preocupação com o fato de estarem dirigidos a futuros professores, e são sustentados por uma concepção de professor explícita e fundamentada, são trabalhos da área temática de História e Filosofia da Ciência.

Esse resultado pode ser interpretado como decorrência da reflexão epistemológica mais ou menos inerente a esse paradigma de pesquisa. Os trabalhos de História e Filosofia tendem a trazer à tona as dimensões de construção histórica do conhecimento científico e seus aspectos sociais e portanto desmistificam a visão da ciência como expressão de uma verdade absoluta e universal. Talvez seja exatamente essa reflexão epistemológica, que permite ver a física de uma forma menos rígida e determinista, o que possibilita uma visão mais aberta do conhecimento em si e a asserção as suas finalidades.

As novas Diretrizes Curriculares para a Formação de Professores da Educação Básica deixam claro que os Cursos de Licenciatura devem construir uma identidade própria, desvinculada dos cursos de Bacharelado. O que percebemos, no entanto, nas pesquisas, é uma quase ausência de trabalhos que se preocupem com o ensino do conhecimento específico de física, levando em conta as especificidades dos licenciandos enquanto futuros professores.

O quadro de resultados de nossa pesquisa aponta, assim, para um problema ainda muito arraigado nos Cursos de Licenciatura. Vemos que a articulação entre os saberes nos currículos desses cursos, enfrenta sérios obstáculos. 


\section{CAPÍTULO 6}

\section{Formação Inicial de Professores de Física - Formatos e Perspectivas}

Fico tão assustada quando percebo que durante horas

perdi minha formação humana. Não sei se terei uma outra para substituir a perdida.

Clarice Lispector

Esse capítulo se destinará, primeiramente, à discussão das várias interpretações, principalmente as presentes na literatura da pesquisa em Ensino de Física, a respeito das novas diretrizes curriculares para formação de professores, e suas contextualizações em análises/propostas referentes a cursos de licenciatura.

Como já mencionado, entendemos a prática como produtora de novos significados e portanto, cabe uma análise mais minuciosa de alguns textos que discutem as diretrizes e as reformas curriculares nos cursos de licenciatura.

Conforme o que foi discutido no capitulo três, entendemos que o próprio texto das diretrizes detêm uma polifonia, que se configura em ambigüidades no documento. A essa configuração polivalente se acrescenta a existência de diferentes interpretações e caminhos que os cursos em seus currículos e práticas têm construído para atender às bases legais e aos interesses dos sujeitos sociais envolvidos. Isso constitui o processo de recontextualização dos textos oficiais no contexto "escolar".

Entendemos ainda que as diretrizes não se restringem a um plano de aplicação, mas se inserem como ingrediente na construção do conhecimento da própria área. Assim tentaremos identificar os conhecimentos 
produzidos pela literatura que se debruçam sobre os cursos, currículos e práticas, as reflexões decorrentes de todo esse movimento, no que concerne a desarticulação entre os saberes na formação do professor e as maneiras pelas quais o conhecimento físico se estabelece em sua relação com os outros conhecimentos na formação.

Para tal análise olharemos mais especificamente os trabalhos da área de Ensino de Ciências, que concretamente se referem à licenciatura, tendo como questão central a preocupação com a formação inicial. Estão nesse grupo as pesquisas que têm como temática os saberes docentes nas licenciaturas, as reformas curriculares de cursos de licenciatura, e os trabalhos que permeiam a questão da desarticulação entre os saberes.

Analisaremos, portanto, um grande subgrupo dos trabalhos pertencentes ao perfil 7 apresentados no capítulo anterior e ainda teses, dissertações e artigos de periódicos, cuja temática se enquadre na descrição acima.

Embora tais pesquisas tenham como foco a licenciatura e, em muitos casos, os currículos dos cursos propriamente ditos, não pudemos perceber muitas correlações com os conhecimentos oriundos do campo dos estudos curriculares. Nesse sentido faremos, em um primeiro momento, uma exposição fidedigna aos trabalhos analisados sem referências ao aporte teórico trazido no capítulo um e na sequência buscaremos refletir sobre essa ausência de diálogo e articulação.

Inicialmente apresentaremos perspectivas trazidas por trabalhos que são anteriores e/ou não apresentam correlação direta com as diretrizes curriculares para formação de professores de 2002, mostrando que algumas reflexões e propostas já persistem há algum tempo.

Adentrando o espaço já claramente marcado pela influência das diretrizes de 2002, perpassaremos alguns trabalhos que investigam de perto a repercussão dessa legislação em casos específicos e que portanto constituem análises mais diagnósticas. $\mathrm{Na}$ sequência propomos uma sistematização de trabalhos que trazem ideias e propostas, ou seja, que trazem espaço para a indução de coisas mais concretas a respeito de disciplinas e da organização curricular das licenciaturas, principalmente no que concerne a articulação dos saberes. 
Ainda nesse capítulo faremos uma breve explanação sobre um caso concreto, que de certa forma, também constitui uma referência exemplar da perspectiva que pretendemos problematizar em relação ao conhecimento físico e seu papel na formação do licenciando.

\subsection{O problema da desarticulação Saber Específico/Saber Pedagógico na Formação Inicial - Perspectivas anteriores às Diretrizes de 2002}

Algumas reflexões acerca do isolamento entre os Saberes Específicos e Pedagógicos, e seus efeitos na formação de professores, têm um histórico anterior ou independente das reflexões desencadeadas pela Diretrizes de 2002.

É possível encontrar alguns trabalhos, que mostram que essas reflexões já vinham sendo delimitadas de alguma forma, desde décadas anteriores, e que ações a fim de articular mais os saberes na formação, já vinham sendo implementadas.

Essas reflexões e ações, se deram por meio de iniciativas diversas, como a iniciada nos seios dos departamentos ou institutos específicos, na criação de disciplinas especiais que não apenas de conteúdo específico. Outras reflexões se apresentaram mais do ponto de vista da educação, com problematizações amplas sobre a formação, que incorporam as discussões presentes na área da formação de professores e a problematização dos estágios e práticas de ensino.

Villani $(1988,1989,1990)$ em uma série de três artigos publicados na Revista Brasileira de Ensino de Física nos anos de 1988, 1989 e 1990, faz uma proposta hipotética de um currículo para formação de professores de física. O primeiro dos artigos mapeia alguns problemas da formação de professores de física e enuncia alguns princípios heurísticos que deveriam guiar essa proposta curricular. O segundo dos trabalhos traz uma discussão acerca do que seriam os objetivos da proposta curricular e o terceiro artigo implica em uma proposta concreta pensada para a Universidade de São Paulo sugerindo disciplinas e detalhando suas propostas.

Embora dentre os princípios e objetivos construídos por Villani $(1988,1989,1990)$ estejam bem delineados problemas como o tratamento inadequadamente formal dos conteúdos de física ressaltando que a física 
ensinada nos cursos superiores não é nem a física atual e nem a física do passado, poucas mudanças se incorporam de fato a proposta curricular em seu âmbito mais prático. O autor defende ainda que haja um ciclo básico comum que aborde os saberes da física para os cursos de Bacharelado e Licenciatura. Quanto aos saberes "educacionais", como se refere o autor, há grande ênfase na potencialidade dos conhecimentos produzidos pela área de ensino de física.

Os artigos de Villani $(1988,1989,1990)$ retratam que desde a década de 80 se iniciava uma expressiva preocupação com a formação de professores de física reconhecendo alguns problemas emblemáticos. No entanto, os aportes propostos não se distanciam muito da filosofia do modelo "3+1". A valorização dos saberes provindos da área de "ensino de física", por outro lado, já começa a se evidenciar.

No que concerne aos institutos ou departamentos de física, podemos citar como disciplina emblemática, a disciplina de "Instrumentação para o Ensino de Física", que foi criada com vistas a suprir certas demandas da formação, e que propunha uma articulação até então inexistente.

O trabalho de Neves (2003) traz um histórico sobre a disciplina "Instrumentação para o Ensino de Física". É apontado que essa disciplina, criada na USP na década de 60, inicialmente com o intuito de instrumentalizar o professor no uso de projetos de ensino (como o $\mathrm{PSSC}^{7}$ ), adquiriu outro caráter na década de 70, e na década de 80 já tinha um papel reconhecido em outros cursos de licenciatura em Física. Esse papel consistia em ser uma interface entre os dois grupos de disciplinas (conteúdos específicos e pedagógicos). Segundo Carvalho e Vianna (apud NEVES 2003):

Essas disciplinas devem fazer a integração, devem proporcionar o caráter abrangente da formação do educador, englobando a adequação, dosagem, organização e aplicação do conhecimento a ser lecionado nos diversos graus e nas diferentes realidades existentes (p. 25).

Ainda segundo essa visão, assumidos os papéis das disciplinas integradoras (como a Instrumentação), o licenciando estaria apto a lecionar e poderia discutir criticamente os conteúdos (NEVES, 2003).

O início da década de 1990 é marcado por debates sobre a

\footnotetext{
${ }^{7}$ Physical Science Study Commitee
} 
licenciatura em Física e há inclusive uma edição da Revista Brasileira de Ensino de Física de 1992 cuja temática se intitula "A Formação do Professor de Física na América Latina: Propostas".

Um dos artigos dessa revista (LIMA, 1992) trata também da modificação do caráter da disciplina de "Instrumentação para o Ensino de Física" relatando caso ocorrido na Universidade Estadual do Rio de Janeiro (UERJ). Segundo a autora, no referido período foram redefinidas a filosofia e a metodologia da disciplina. Buscando justamente um diálogo entre os saberes da área específica da física e os saberes educacionais foram introduzidos na disciplina saberes da área de ensino de física. A autora destaca a mudança do caráter dessa disciplina, que antes visava apenas o domínio de técnicas e experimentos, para uma abordagem pautada em textos de "ensino de física". Aqui novamente, vemos a tendência de valorização dessa área como alternativa aos problemas do modelo de formação vigente.

Dessa mesma edição temática da revista Brasileira de Ensino de Física destacamos mais três artigos, dos quais dois relatam propostas curriculares de cursos de licenciatura em física e um traz uma reflexão sobre um curso de licenciatura obtida a partir de uma disciplina realizada nos últimos períodos.

Barreiro (1992) disserta sobre a proposta de um curso de Ciências da Natureza a ser implementado no campus de São Carlos da Universidade de São Paulo. Argumentando que o distanciamento entre a formação acadêmica oferecida no esquema bacharelado-licenciatura e a realidade do ensino no $2^{\circ}$ grau é um problema desses cursos, a proposta que apresenta traz uma formação eminentemente prática e interdisciplinar. $\mathrm{Na}$ proposta curricular trazida pelo artigo o licenciando cursaria um ciclo básico comum, que the permitiria uma formação interdisciplinar e depois um ciclo especializado que the permitiria um aprofundamento e Ihe daria a habilitação em Física, Química ou Matemática.

Amato e Souza (1992) abordam a proposta de criação de um curso noturno de licenciatura em Física na Universidade de Brasília. A proposta incorpora muito da discussão trazida por Villani (1988, 1989, 1990), como a defesa de um ciclo básico comum e de um ciclo profissional composto de disciplinas de didática específica e disciplinas pedagógicas. Há ainda a 
preocupação do grupo elaborador do currículo em adaptar uma proposta mais genérica, ou seja, a proposta de Villani (1988, 1989, 1990), à ideia de um curso noturno. Nessa adaptação são alteradas cargas horárias e é aumentado o tempo total do curso.

Almeida (1992) aborda quais seriam os elementos a serem acrescentados na formação inicial do professor de física defendendo uma concepção autônoma do professor. Nesse sentido se pergunta: como formar indivíduos que não atendam apenas às necessidades de uma parcela privilegiada da população? (ALMEIDA, 1992, p. 146). A autora questiona então as finalidades de um curso superior e destaca seu esforço enquanto docente de uma disciplina de final de curso, na qual detectou muitos problemas na formação dos alunos, e procurou confrontá-los com problemas típicos da sala de aula do ensino médio.

Algumas outras perspectivas apontadas de um ponto de vista mais ligado à educação podem ser exemplificadas do trabalho de Abib (1997), que sistematiza grandes problemas a respeito da formação de professores. Dentre eles está a desarticulação que se explicita por meio de disciplinas estanques de conteúdo específico e conteúdo pedagógico, e na visão do professor como profissional técnico executor de tarefas.

Assim, a autora aponta como resultados formativos dessa configuração dos cursos:

- que o licenciando em sua prática futura, reproduz a desarticulação, as práticas vivenciadas e os valores presentes em sua formação,

- que apresenta uma prática em sala de aula centrada em mecanismos de transmissão/recepção/fixação de um conteúdo pronto, pretensamente neutro, e que veicula um ensino definido pela função de transmissão de um conteúdo que se constitui o próprio fim da existência escolar.

Carvalho (1992) em uma reflexão sobre os cursos de licenciatura, já apontava a existência de uma pluralidade de saberes e destrezas que o professor mobiliza em sua ação, que vai muito além dos dois grupos de conhecimentos que tradicionalmente compunham os currículos de 
formação de professores: o específico e o pedagógico. Nesse mesmo ensaio a autora destaca a importância da integração entre o componente acadêmico desta formação e a prática docente. Ela ressalta ainda que a Didática Especial (corpo de conhecimentos fundamentados na áreas de "ensino de") pode ter, precisamente, este papel integrador.

Além disso, nas décadas de 80 e 90 houve ampla discussão sobre formação de professores no Brasil, em parte representados pelos trabalhos da ANFOPE, que apontaram para uma reorganização curricular dos cursos de graduação (ABIB, 1997).

Numa revisão bibliográfica nos documentos da ANPEd, evento também significativo na área de formação de professores, Brzezinski e Garrido (2001), fazem uma análise das produções dos GTs sobre formação de professores no período de 1992 a 1998. Em relação à formação inicial nas licenciaturas, é destacado segundo as autoras, que há uma inadequação da formação nos cursos de licenciatura, particularmente no que se refere à dicotomia entre formação pedagógica e formação específica, à fragilidade da formação pedagógica e à descaracterização das faculdades de educação. Nesse sentido alguns dos trabalhos analisados apresentam propostas curriculares inovadoras ${ }^{8}$, das quais algumas tentam enfrentar a fragmentação dos currículos por meio de eixos articuladores e atividades interdisciplinares.

Do panorama explorado até aqui no capítulo, percebemos que a desarticulação entre os saberes já é um problema apontado há algum tempo por especialistas e professores que refletem sobre as licenciaturas, e cuja solução já se tentava, como mostram os exemplos da disciplina de Instrumentação e as reflexões trazidas pela área de Educação.

Algumas das perspectivas aqui citadas foram em parte incorporadas pelas "Novas Diretrizes para Formação de Professores da Educação Básica" de 2002, já discutidas no capítulo três.

\subsection{Impacto e Repercussão das Diretrizes}

A revisão que fizemos até aqui revela a existência de um

\footnotetext{
${ }^{8}$ As propostas inovadoras mencionadas se referem aos trabalhos de Taffarel (1994), Ludke e Goulart (1994), Viana (1992), Angotti (1994), Carvalho (1992), Colinvaux (1993), Mazzotti (1993), Castanho et al. (1992), todos em mimeo cuja consulta não foi possível.
} 
grupo de pesquisas que situa em sua análise, de distintas formas, o problema da desarticulação entre os saberes na formação inicial de professores. Destacaremos na seqüência, alguns trabalhos que apontam e delimitam o problema dos saberes específicos e pedagógicos nos cursos de licenciatura, já no contexto marcado pela repercussão das diretrizes para formação de professores de 2002.

Abordaremos inicialmente os trabalhos que constituem análises mais específicas e principalmente diagnósticas acerca da repercussão das diretrizes em casos concretos.

Silva (2004) traz uma reflexão sobre as "Novas Diretrizes para Formação de Professores" e aponta algumas contradições nos documentos que regem essa tentativa de reforma. Em seu trabalho, buscando indícios de como as proposições da legislação foram incorporadas na prática, são apresentados trechos de entrevistas com coordenadores de cursos de Licenciatura em Matemática em instituições paulistas públicas e privadas. $O$ autor destaca que as diretrizes se encontram a anos-luz do que existe efetivamente nos cursos e que a visão de unidade, trazida pelas diretrizes, esbarra em uma característica presente em quase todos os cursos visitados: a divisão do grupo docente, de acordo com suas concepções pessoais.

Terrazzan et al (2008) apresentam um estudo sobre reformulações ocorridas em Cursos de Licenciatura, por meio da análise dos projetos políticos pedagógicos de cursos de licenciatura em Física, Química e Ciências Biológicas da UFSM. Os autores explanam sobre os modelos de formação da racionalidade técnica e da racionalidade prática, afirmando que esse último está bem presente nas atuais normativas legais, como as "Diretrizes para Formação de Professores da Educação Básica". Os aspectos analisados nos Projetos Pedagógicos dos cursos foram organizados em: disciplinas referentes ao Estágio Curricular, organização das disciplinas consideradas parcial ou integramente dedicadas à Prática como Componente Curricular e organização das disciplinas referentes à Formação Pedagógica. O estudo conclui que, mesmo em se tratando de licenciaturas na mesma Instituição, não há um padrão quanto às formas de organização das citadas componentes curriculares. É apontado que os cursos de Licenciatura em Física e em Ciências Biológicas, apesar de terem se 
reformulado para respeitar as cargas horárias propostas na nova legislação, ainda apresentam grande semelhança com a formação proposta em legislações anteriores.

Cortela (2004) apresenta uma extensa análise realizada a partir de entrevistas com professores formadores da licenciatura em física, com vistas a responder à questão de como o corpo docente de um curso de licenciatura de uma Universidade Estadual Paulista vem reagindo frente às mudanças curriculares desencadeadas, entre outros aspectos, pelas diretrizes curriculares para formação de professores. A pesquisa aponta que a maioria dos docentes está descontente e concorda que o modelo tradicional não dá conta de formar, de maneira satisfatória, professores para o Ensino Médio. Todos os docentes citam com muita ênfase que o bom profissional deve dominar os conteúdos específicos da disciplina que vai ensinar. Quanto aos conteúdos pedagógicos, predomina entre os professores o paradigma técnicoracionalista. Fica explicitado, também, que entre os docentes há um profundo desconhecimento dos documentos oficiais, que regem tanto a formação de professores, quanto o ensino básico. Nesse caso, podemos observar que 0 problema da desarticulação persiste claramente, mesmo após as reformas.

Os autores citados nos apresentam situações concretas que apontam para certo distanciamento no que foi proposto pelas reformas e o que parece estar ocorrendo na prática, pelo menos no que concerne aos cursos analisados e aos olhares apresentados.

As convicções pessoais dos professores formadores e as estruturas universitárias estabelecidas e consolidadas parecem ser elementos que influem de forma robusta nos movimentos de transformação (ou não transformação) dos cursos.

As mudanças curriculares esperadas, no entanto, parecem esbarrar em um obstáculo que corrobora com as análises de Gatti e Barreto (2009) de que nas instituições universitárias públicas, alterações estratégicas de currículo ou estrutura organizacional implicariam remanejamentos institucionais e de docentes, o que demandaria mudança da cultura formativa, de representações cristalizadas. 


\subsection{Propostas e Ideias}

Entendendo que qualquer legislação não se restringe a um plano de aplicação de regras e diretrizes, mas se insere como ingrediente na construção do conhecimento da própria área, nos propomos a mapear as propostas e ideias que estão se consolidando a partir das discussões induzidas pelas Diretrizes.

Encontram-se aqui trabalhos que têm uma perspectiva mais indutora de mudanças concretas nos currículos, cursos e práticas de forma mais direta.

Segundo Contreras (2002): ...devemos levar em conta que as políticas não só criam âmbitos
legais e diretrizes de atuação. Também supõem a expansão de
idéias, pretensões e valores que paulatinamente começam a se
transformar de modo inevitável. As reformas não são apenas
mudanças que se introduzem na organização e no conteúdo da
prática educativa, mas também formas de pensá-la. (Contreras, 2002,
p. 228)

Assumindo essa perspectiva abordaremos então alguns recortes que refletem ideias e propostas para pensar a formação de professores, e que parecem ter relação direta com aspectos trazidos à tona pelas Diretrizes de 2002.

Nesse sentido organizamos as pesquisas delimitando os trabalhos que: defendem ideias e propostas mais circunscritas a uma ou outra área do currículo; os aportes que dizem respeito à prática como componente curricular; e os aportes que são mais amplos, pensando o currículo em sua totalidade.

\subsubsection{Aportes Curriculares Circunscritos}

Alguns dos trabalhos analisados são mais circunscritos à área de educação e enaltecem a Prática de Ensino, como é caso de Marandino (2003) e Zimmermann e Bertani (2003).

Segundo Marandino (2003), cuja perspectiva teórica incorpora boa parte das discussões trazidas pelas novas Diretrizes, a Prática de Ensino na área de Ciências Naturais deve promover a articulação dos saberes específicos com os pedagógicos, procurando incorporar em seu programa 
questões educacionais mais abrangentes e também a educação científica.

Zimmermann e Bertani (2003) priorizam dentro dos questionamentos a respeito da formação do professor a questão da separação entre a pedagogia e o conteúdo científico. Para esses autores é a partir da prática de ensino reflexiva que se dará essa integração. E é por articular as disciplinas didático-pedagógicas com as de cunho específico (matemático, neste caso), "que a disciplina de Prática de Ensino desempenha um papel decisivo para a formação de professores" (ZIMMERMANN E BERTANI, 2003, p. 54).

Há alguns outros trabalhos que delimitam aportes mais alinhados com a implementação de disciplinas integradoras no currículo. Exemplos de disciplinas dessa natureza são as "metodologias de ensino de", as "instrumentações", "oficinas de ensino" e etc.

Silva Sá e Santos (2009), em trabalho que discute uma reforma curricular inovadora em um curso de química, defendem que os conhecimentos da área de "ensino de química" são muito eficientes como solução ao problema da desarticulação, embora seja apontado que isso não dá conta da integração necessária.

Passos e Del Pino (2009) apresentam, em sua pesquisa, resultados comparativos de questionários aplicados a professores $\mathrm{e}$ licenciandos de um curso de Licenciatura em Química no RS. A perspectiva trazida pelos autores é bastante alinhada com as Diretrizes Curriculares Nacionais para Formação de Professores da Educação Básica, documento que é citado e objeto de reflexão ao longo do texto várias vezes. Os autores enaltecem o papel das disciplinas articuladoras presentes no currículo do curso de Licenciatura em Química do RS, que parecem ser a principal fonte dos conhecimentos efetivamente mobilizados pelos professores de química, no que concerne ao ensino que se tem como desejável.

Berlitz e Ostermann (2005) propõem e discutem ações referentes à disciplina de "Metodologia de Ensino de Física I", em um curso de licenciatura em Física. As autoras refletem sobre a fragmentação dos conteúdos que são desenvolvidos nesse curso, ressaltando uma conseqüência dessa formação, que é a pouca capacidade dos licenciandos de relacionar os conteúdos específicos aos conhecimentos pedagógicos. Nesse 
sentido propõem uma abordagem inovadora para a disciplina em questão, na qual os alunos são levados a relacionar referenciais de ensino-aprendizagem e de epistemologia aos experimentos que desenvolvem.

\subsubsection{A Prática como Componente Curricular}

A "prática como componente curricular" é um exemplo de elemento trazido pelas diretrizes e cuja incorporação se fez necessária por exigência legal. Porém, além de se tratar de um elemento novo (diferente do estágio supervisionado, que de alguma forma já era praticado), a sua definição no texto das diretrizes é bastante confusa.

Esse elemento poderia ser interpretado como uma das formas de conseguir uma maior articulação entre os saberes na formação inicial, e merece atenção especial, pois a forma como vem sendo incorporado apresenta diferenças bastante gritantes, que apontam para recontextualizações muito distintas.

Silva (2004), analisando um curso de Licenciatura em Matemática, conclui que existem inúmeras divergências quanto ao entendimento da "Prática como Componente Curricular". Ficam explicitadas desde concepções de que essa prática caberia a disciplinas pedagógicas, como outras interpretações, nas quais elas seriam atribuição de todas as disciplinas, inclusive das de Matemática. Porém nesse caso, essas interpretações parecem convergir para a ideia de que prática como componente curricular apresenta-se como sinônimo de qualquer atividade no curso que não seja uma aula expositiva.

Terrazzan et al (2008), em sua análise dos Projetos Políticos Pedagógicos de três cursos de Licenciatura, em Física, Química e Ciências Biológicas da mesma instituição, afirmam que a "Prática como Componente Curricular" (PCC) está distribuída de forma distinta nos três cursos, tanto em relação aos departamentos a que estão vinculadas, como em relação aos conteúdos que serão desenvolvidos. Segundo os autores, ora a carga horária total de PCC aparece distribuída entre disciplinas que desenvolvem somente aulas práticas, ora aparece distribuída entre disciplinas que desenvolvem tanto atividades teóricas como atividades práticas.

Biasus (2006), baseada em um estudo amplo sobre as 
licenciaturas realizado em quatro Instituições Federais de Ensino Superior do Estado do RS, conclui que existem diferentes interpretações e encaminhamentos para as 400 horas de Prática como Componente Curricular nos cursos de Licenciaturas, até mesmo dentro de uma mesma instituição, o que leva, a partir disso, a inferir que o texto das DCNFPEB apresenta-se ambíguo.

\subsubsection{Aportes curriculares mais amplos}

Alguns autores trazem à tona ideias e propostas que problematizam o ensino nas licenciaturas e procuram olhar para o processo formativo de forma mais ampla.

Arroio (2009) problematiza os saberes do professor de ensino superior e a relação desses com sua prática docente lembrando o conceito de simetria invertida. Aponta como importante aspecto a preocupação com a formação dos pós-graduandos. Enfatiza que "não se deve entender a formação do pós-graduando como uma somatória de disciplinas científicas com disciplinas pedagógicas e sim, como um amadurecimento ao longo da formação inicial continuando em formação posterior" (ARROIO, 2009, p.10). Nessa pesquisa podemos perceber a presença do paradigma dos "saberes da prática" e a idéia de que a lacuna entre os saberes pedagógicos e científicos na formação pode ser atenuada mediante um amadurecimento profissional, advindo da experiência.

Silva at al (2008) defendem que a articulação entre os conhecimentos específicos e pedagógicos deveria se realizar por meio de disciplinas integradoras e também por ações extra disciplinares. Também é conferida grande importância ao estágio supervisionado como espaço privilegiado para a superação dessa dicotomia.

Garcia e Garcia (2004) reconhecem que a consolidação histórica do modelo de formação " $3+1$ " introduziu dicotomias de difícil superação, como a dicotomia saber específico/saber pedagógico. No artigo, a

dicotomia entre saberes específicos e pedagógicos apresenta-se como questão central a ser superada. Para isso, a proposta de curso, a ser implementada e discutida no artigo, apresenta vários espaços curriculares, que vai além dos tradicionais espaços do conteúdo específico e da educação 
incorporando outros elementos. São os espaços dos Conhecimentos Complementares e/ou Interdisciplinares, dos Conhecimentos Metodológicos e o espaço do Estágio Curricular. Segundo os autores:

No espaço dos Conhecimentos Metodológicos, encontram-se as disciplinas que, por estabelecerem uma articulação entre os conhecimentos específicos de Física e de Educação, conferirão ao aluno as competências e habilidades para o exercício de suas futuras atividades docentes junto a escolas de Ensino Médio e de Ensino Fundamental (p. 8)

\subsubsection{Considerações sobre as propostas e ideias}

Nossa análise revela que há uma tendência, que de alguma forma enaltece a importância de um "conhecimento integrador" para articular melhor os conhecimentos que compõem as licenciaturas. E a principal referência desse conhecimento integrador são as áreas de "ensino de" (Ensino de Física, Ensino de Química, Ensino de Matemática).

Esses saberes integradores são uma amálgama de conhecimentos, compostos pelas metodologias e pelas didáticas específicas, e por conhecimentos educacionais que orientam a prática do professor.

Assim, se incorporam ao bloco de conhecimentos integradores os conhecimentos sobre ensino aprendizagem próprios de uma dada área, as noções que podem ser desenvolvidas nas práticas de ensino (como a reflexão na ação, a pesquisa da própria prática, a reflexão crítica), as técnicas e métodos específicos de um tipo de conhecimento, e suas filosofias, histórias e etc.

Dentro desse paradigma, podemos perceber que embora os trabalhos problematizem a questão da desarticulação entre os conhecimentos na formação de professores, não há uma perspectiva de reestruturação geral nos cursos de formação. O estágio supervisionado, a prática de ensino, as disciplinas de didática específica, e disciplinas com cunho mais histórico, social, filosófico, são enaltecidas como espaços privilegiados para a formação do professor de forma mais integrada. Em alguns casos aparece a noção de que a própria prática, acompanhada dos processos de reflexão e pesquisa, pode fazer esse papel integrador.

Os núcleos pedagógicos e de conhecimentos específicos dos cursos e suas disciplinas tradicionais não são problematizados. Fica 
implícita a concepção de que esses compartimentos estanques têm sua importância reconhecida e legitimada, desde que sejam integrados por elementos adjacentes.

Reconhecendo o poder de influência da legislação na construção do próprio conhecimento da área, percebemos que esse paradigma, do "bloco integrador", tem se consolidado cada vez mais na área de pesquisa em Ensino de Ciências.

Acreditamos que essa visão tem suas limitações e como afirmam Higa (2005) e Oliveira (2006), mesmo as disciplinas de interface não têm sido capazes de eliminar ou minimizar a nítida separação entre conteúdo específico e pedagógico.

\subsection{Um Caso Referência - o Curso de Licenciatura do Instituto de Física da USP}

No sentido de reconhecer que mesmo o bloco integrador de disciplinas não dá conta de minimizar a fragmentação existente nos cursos de formação, nos dirigimos para a problematização dos próprios saberes específicos. Isso nos leva novamente à reflexão sobre qual é a física a ser ensinada nos cursos de licenciatura.

A ideia de que a Física a ser ensinada em um curso de licenciatura não é a mesma que em um curso de Bacharelado e a problematização da relação desse conhecimento com a finalidade da licenciatura, já surgiu há algum tempo no curso de Licenciatura em Física da Universidade de São Paulo.

A partir de 1993 foi implantado o currículo do curso de licenciatura em Física, no qual a maior parte das disciplinas possuía uma proposta diferenciada em relação às do bacharelado. Disciplinas como Fundamentos de Mecânica, Oscilações e Ondas, Ótica, Termodinâmica 1 e 2 e Gravitação, deveriam apresentar um enfoque metodológico distinto dos tradicionalmente apresentados no currículo anterior da licenciatura, em que eram idênticos ao Bacharelado (SILVA, 1998).

Oliveira (2006) relata mais alguns aspectos desse curso:

Por exemplo, as cadeiras Física 1, 2, 3, e 4, do ciclo básico, tratavam de maneira introdutória conteúdos de toda a física clássica nos 
primeiros dois anos da graduação (...). Na nova licenciatura as disciplinas receberam nomes específicos do conteúdo que devem abordar, como Fundamentos da Mecânica, Óptica, Eletricidade 1 e 2, Gravitação, entre outras. Além de tratar o conteúdo físico formal, estes novos espaços curriculares já se preocupam com questões pedagógicas, não relegando apenas à $\mathrm{FE}^{9} \mathrm{o}$ ônus desta formação. ( $\mathrm{p}$. 71)

Um exemplo de disciplina trabalhada nesse curso, de forma diferenciada é a disciplina de Gravitação, objeto de estudo de Silva (1998). Essa autora relata que essa disciplina foi concebida: "com a intenção de mostrar a física de uma forma totalmente diferenciada da que vinha sendo ensinada até então" (p.30).

Segundo Oliveira (2006), dessa forma, o conteúdo de física tornou-se outro, e o licenciando foi contemplado com uma nova perspectiva. Nas palavras de João Zanetic, o professor idealizador da disciplina:

\begin{abstract}
O objetivo central da construção dessa disciplina e principalmente das aulas, quando vou além daquilo que está no texto e exploro a situação sócio-econômica e cultural da época em que os conceitos, os experimentos, e as teorias foram desenvolvidas, é baseado no trabalho que desenvolvi em minha tese de doutorado quando estabeleço a compreensão de que a física tem que ser vista como uma construção cultural, a física como uma construção que leva em conta uma multiplicidade. Assim, a física apresentada para o aluno, mesmo que ele vá ser físico ou professor de física, contempla obviamente os conceitos, a experimentação, a matemática (o algoritmo), mas ela contempla também as decorrências filosóficas, as decorrências de outras áreas do conhecimento e, portanto, também leva em consideração as contribuições dessas outras áreas para a própria construção do conhecimento em física. Era essa a perspectiva que eu tinha. Meu objetivo é combinar um pouco a solução de problemas tradicionais no ensino de física com uma construção cultural, principalmente tendo em vista que os nossos alunos são potencialmente professores de física, eu quero ver essas ideias levadas para o nosso $2^{\circ}$ grau (ZANETIC apud SILVA 1998).
\end{abstract}

Essa proposta de licenciatura, implementada de forma pioneira na década de noventa, por um então grupo de professores do Instituto de Física da USP, encontrou muitas barreiras ao longo desses anos e muitas de suas características vêm sendo modificadas. A disciplina de Gravitação, no entanto, tem conseguido manter suas características.

\title{
6.5 Considerações sobre os Formatos e Perspectivas dos cursos de Licenciatura
}

O problema concreto, presente tanto na legislação quanto na

\footnotetext{
${ }^{9}$ Faculdade de Educação.
} 
literatura, e sobre o qual buscamos refletir, é referente ao que acontece hoje em muitos cursos de licenciatura. O modelo de formação consolidado, conhecido por " $3+1$ ", baseado no paradigma também muito consolidado da "Racionalidade Técnica", se encontra ainda muito arraigado tanto na estrutura universitária quanto nos sujeitos sociais envolvidos nos cursos de formação.

Esse modelo de formação traz consigo uma visão que fragmenta de forma persistente o conhecimento pedagógico e o conhecimento específico. Nossa análise corrobora com a de Gatti e Barreto (2009), que atribuem a fragmentação interna em termos de currículo, no que concerne em geral às licenciaturas, parece corresponder a interesses institucionais diversos, como a existência de nichos institucionais cristalizados, ou à falta de perspectivas quanto ao perfil formador do profissional professor.

Outra contribuição para refletir sobre esse isolamento das áreas específicas é apresentada por Delizoicov (2008), ao tratar da docência no Ensino Superior. Ele discute, entre outros aspectos, o papel do físicopesquisador como docente. Destaca que, na realidade das Instituições de Ensino Superior Brasileira, o físico-pesquisador (aquele docente com formação e atuação em alguma área específica da física) tem, também, um papel na formação de professores de física do ensino médio, ainda que nem sempre o reconheça. Assim, sua prática educativa não deveria ter a finalidade exclusiva de manutenção e ampliação da comunidade de físicos.

A promulgação das novas diretrizes curriculares para formação de professores do ensino básico traz com a força da legislação, uma visão que busca, dentre outros aspectos, a integração dos saberes na formação do professor, legitimada por uma visão de educação mais ampla. Esse cenário induziu muitos cursos de formação a refletirem seus currículos e práticas. A mudança se fez necessária, pelo menos no que diz respeito as cargas horárias, instituídas pela resolução CNE/CP №1 de 2002.

Diante desse contexto, nosso levantamento aponta ainda que a literatura da pesquisa voltada à discussão dessas licenciaturas, comprometida com uma reflexão mais fundamentada a esse respeito, consolida um paradigma e valoriza toda uma área de saberes pronta a prestar, dentro dos cursos de formação, um serviço de integração, por meio de disciplinas integradoras (Prática, Estágio, Instrumentações, Metodologias e 
etc.).

Como apontado por alguns estudos, como o de Higa (2005) e Oliveira (2006), acreditamos que essa visão de integração apenas se sobrepõe a uma fragmentação que continua a existir. Não nos parece que esse novo paradigma irá dar conta de uma formação de professores que supere a visão técnico racionalista.

O que estamos buscando construir nesse trabalho é a tese de que, para superar de fato do paradigma técnico racionalista e caminhar em direção a uma formação crítica de professores, é preciso desnaturalizar tanto os saberes pedagógicos quando os saberes específicos nos seios dos cursos de formação.

A perspectiva crítica do currículo, que questiona de fato a "lógica" pela qual os saberes são selecionados e organizados no currículo parece estar ainda muito distante das reflexões que são apresentadas pela área de ensino de ciências e pelos estudos que pesquisam os currículos e práticas dos cursos de licenciatura.

Como apontam Ferreira e Moreira (2001), a pouca interlocução da área de Ensino de Ciências com o campo do currículo:

faz com que os mecanismos de seleção e organização do conhecimento sejam abordados de modo naturalizado, como se as decisões nesse campo tivessem origem apenas nos aspectos relacionados à produção do próprio conhecimento científico (FERREIRA E MOREIRA, 2001, p.3)

O trabalho de Potenza (2011), que é um exemplo de interlocução possível da área de ensino de ciências com o campo do currículo, traz uma análise de como disciplinas de conhecimento científico específico, em cursos de licenciatura, estão ou poderiam estar contribuindo para a prática futura de seus alunos. Nesse sentido, analisa especificamente a disciplina de Física Moderna, levantando características, propostas e dificuldades de aprendizado. Do aprofundamento dessas questões, a autora propõe que grande parte das dificuldades tem origem no descompasso de finalidades formativas do ensino superior e médio.

Nessa perspectiva, a autora aponta que as dificuldades referentes à aprendizagem de Física Moderna se dão por uma total falta de sentido dessas disciplinas para os futuros professores. E essa falta de sentido 
existe também no aprendizado da física clássica, mas nesse caso, os conteúdos do Ensino Médio já estão estruturados e sua atividade profissional futura é mais independente de uma efetiva aprendizagem no curso de formação em si. Concordamos com a afirmação de que:

as finalidades da disciplina devem ser explicitadas aos/ pelos professores formadores e seus alunos. Elas precisam ser destacadas e discutidas para que a disciplina seja pensada de modo a cumprir a sua missão.(...) Entender quais são as finalidades da disciplina de Física Moderna I, por que o são e o contexto no qual se inserem, sinalizam ao licenciando as possibilidades de sua ação no que se refere ao currículo, por meio de escolhas conscientes e autônomas enquanto professor. (POTENZA, 2011, p. 126/127)

Diante do quadro desenhado até aqui chamamos atenção ainda para um importante aspecto institucional. Nos capítulos três e quatro perpassamos de forma muito breve alguns aspectos históricos tentando entender como o modelo de formação "3+1" se estabeleceu e se consolidou. E dentro desse processo destacamos a institucionalização das Faculdades ou Departamentos de Educação como institutos próprios e relativamente autônomos dentro das universidades.

Com essa configuração essas instituições parecem ter assumido papéis específicos na formação de professores. Esse aspecto parece se refletir também nas pesquisas. Isso significa que o conjunto de pesquisadores com alguma familiaridade com a área de conhecimento da educação voltam predominantemente seus olhares para uma parte do currículo. Nesse sentido "induzem" várias ações na direção de pensar a formação profissional do futuro professor, mas sem tocar a parte do currículo que "fica fora" das Faculdades/Departamentos de Educação.

Nessa linha de argumentação destacamos o contraste que instituições formadoras de professores desprovidas dessa estrutura (ter uma Faculdade/Departamento específico de Educação) podem trazer para o debate acerca da articulação dos saberes docentes na formação inicial. 


\section{CAPÍTULO 7}

\section{Possibilidades e Desafios - 0 caso do IFSP}

A necessidade é a mãe da inovação.

Platão

Entrelaçando as áreas do currículo e da formação de professores, propusemos até aqui um percurso a fim de refletir sobre a licenciatura em física. Nesse caminho perpassamos uma interpretação dos documentos oficiais nacionais atualmente em vigor, uma breve compreensão histórica, e alguns olhares de pesquisa, tanto num espectro mais geral da área de ensino de ciências, quanto em abordagens mais voltadas aos cursos de licenciatura em si.

No intuito de percorrer esse caminho, das instâncias mais amplas até contextos mais delimitados, culminamos aqui em mais uma etapa de pesquisa, ao focar o arsenal teórico até aqui desenhado no entendimento de um caso concreto.

Nosso objetivo nessa etapa é buscar um olhar atento sobre uma prática concreta, em um contexto delimitado, marcado pelas discussões mais amplas apresentadas anteriormente. Buscaremos a compreensão do projeto formativo existente tanto no nível institucional como específico do curso de licenciatura em física que nos propomos a investigar. Intentamos também entender melhor como se dá a relação entre os sujeitos envolvidos na execução desse projeto formativo, a estrutura curricular, os saberes e as finalidades envolvidas.

Nesse sentido buscaremos indícios de possibilidades reais de articulação dos saberes na formação, verificando, de certo modo, a viabilidade de propostas e práticas curriculares inovadoras. Tentaremos compreender se é viável e de que maneira seria possível superar tanto a desarticulação, como a profunda naturalização do conhecimento corporificado no currículo. 
Apresentamos, então, nesse capítulo, um "estudo em caso". Usaremos essa terminologia, pois embora nessa etapa estejamos nos debruçando sobre um caso específico, a compreensão cabal e detalhada da realidade em questão não é nosso objetivo. O que pretendemos de fato é a compreensão do problema pesquisa já apresentando em uma realidade concreta. Assim, prosseguimos nossa investigação, agora, em um lócus mais concreto, ou "em caso".

Buscaremos observar numa realidade concreta, em um caso com especificidades bem marcantes, como é que os elementos até aqui estudados como os saberes docentes, as articulações entre esses saberes e as finalidades educativas se entrelaçam na prática.

Nesse sentido procuraremos ao mesmo tempo dar mais sentido aos elementos teóricos trazidos ao longo do trabalho e apontar possíveis caminhos e práticas.

Se movimentos de desarticulação e desnaturalização se mostrarem possíveis pretendemos ainda verificar quais são as contribuições e limitações da realidade em questão.

\subsection{Delimitação do Problema}

Nossa pesquisa apontou até aqui a existência de paradigmas muito consolidados nos cursos de licenciatura, e vários deles são resquícios do emblemático modelo " $3+1$ ". Esses resquícios, ainda muito persistentes especialmente nas áreas de ciências exatas, têm preconizado uma fragmentação dos saberes. No entanto, e ainda que as propostas de integração permeiem de alguma forma a área de formação de professores e sejam abordadas nas legislações atuais, as resistências a quaisquer mudanças parecem fortemente institucionalizadas.

Alguns trabalhos do capítulo seis apontaram como dificuldades à articulação dos saberes na formação, tanto a estrutura universitária departamentalizada, como as perspectivas pessoais dos docentes que ministram aulas em disciplinas desses cursos, e sua vocação de pesquisadores em áreas específicas.

Nesse sentido, o caso que elegemos para a pesquisa de instâncias mais concretas, possui características muito diferenciadas. Trata- 
se, primeiramente, de um curso locado em um Instituto Federal, e que, portanto, está fora do escopo da universidade propriamente dita. E, em parte por isso, ele apresenta uma estrutura institucional na qual não há uma divisão dos docentes que atuam no curso em departamentos isolados.

Outra característica importante se encontra no histórico desse curso. Ele foi criado logo depois das novas diretrizes curriculares (ainda em 2001) e por vontade (não imposição) de um grupo de então professores do Ensino Médio.

O fato dessa iniciativa, de criar um curso de licenciatura, não ter se dado por imposição de órgãos superiores, também é muito peculiar, e diferencia esse caso, da posterior expansão de cursos de Licenciatura em Institutos Federais (iniciada em 2008).

Buscaremos portanto, nessa realidade concreta, elementos da prática que nos dêem indicadores da possibilidade de maior articulação entre os saberes na formação de professores. Tentaremos investigar em que sentido se estabelecem as relações entre a proposta e os sujeitos envolvidos, como as práticas se constituem e, mais especificamente, como os saberes, especialmente os de física, permeiam essa dinâmica.

\subsection{Procedimentos de investigação}

O universo que constitui os dados que serão investigados é constituído pelos documentos da proposta do curso de Licenciatura do IFSP e outros escritos institucionais, além de entrevistas.

O acervo estudado na etapa da análise documental foi constituído por textos e documentos encontrados no site institucional do IFSP e também no site exclusivo do Curso de Licenciatura em Física do IFSP, bem como pelo texto do Projeto Político Pedagógico do curso.

Além da análise documental, foram realizadas entrevistas com alguns docentes, a partir das quais se buscou identificar de que forma se apresentam e articulam o papel da própria legislação, as características institucionais e, também as trajetórias pessoais desses protagonistas.

Acompanhou-se a forma como, atualmente, um grupo de professores desenvolve seu discurso e norteia suas práticas, no que diz respeito aos saberes presentes na formação inicial de um professor de física. 
Essa investigação pretendeu buscar subsídios também para compreender quais elementos favorecem/ou não a efetivação das mudanças curriculares em novas práticas, mesmo que parciais. Nesse sentido, investigou-se a interpretação dado o quadro potencialmente inovador existente, as alterações introduzidas, os comprometimentos (pessoal e da instituição) e, sobretudo, a percepção de docentes formadores em relação ao curso.

Foram entrevistados seis docentes que, em nossa leitura, apresentam trajetórias profissionais e histórias de vida distintas. As entrevistas seguiram o formato semi-estruturado, com roteiro aberto. Os docentes entrevistados foram denominados A, B, C, D, E, F. Usaremos essa nomenclatura nas transcrições ao longo do texto. A tabela 7.1 sistematiza as principais características dos entrevistados.

\begin{tabular}{|c|c|c|}
\hline$\overline{\mathrm{CA}}$ & Docente B & Docente C \\
\hline $\begin{array}{l}\text { Docente do IFSP desde } \\
\text { 2006. Fez Bacharelado na } \\
\text { área de Física e depois } \\
\text { cursou a Licenciatura } \\
\text { concomitante com } \\
\text { Mestrado em Física. }\end{array}$ & $\begin{array}{l}\text { Docente do IFSP desde } \\
\text { 2002. Fez primeiramente o } \\
\text { curso de Bacharelado e } \\
\text { depois concluiu a } \\
\text { Licenciatura e o Mestrado } \\
\text { em Ensino de Física e o } \\
\text { Doutorado em Educação. }\end{array}$ & $\begin{array}{l}\text { Docente do IFSP desde } \\
\text { 2003. Começou o curso de } \\
\text { bacharelado e mudou para } \\
\text { Licenciatura. É mestre em } \\
\text { Ensino de Física e cursa o } \\
\text { doutorado na mesma área. }\end{array}$ \\
\hline Docente $\mathrm{D}$ & $e E$ & te $F$ \\
\hline $\begin{array}{l}\text { Docente do IFSP desde } \\
\text { 2006. Fez primeiramente o } \\
\text { curso de Bacharelado e } \\
\text { depois concluiu a } \\
\text { Licenciatura concomitante } \\
\text { com o Mestrado. Fez } \\
\text { Doutorado em Física. Já } \\
\text { foi professor da rede } \\
\text { pública estadual. }\end{array}$ & $\begin{array}{l}\text { Docente do IFSP desde } \\
\text { 2006. Fez primeiramente o } \\
\text { curso de Bacharelado e } \\
\text { depois concluiu a } \\
\text { Licenciatura concomitante } \\
\text { com o Mestrado. Fez } \\
\text { doutorado e pós doutorado } \\
\text { em astrofísica. }\end{array}$ & $\begin{array}{l}\text { Docente do IFSP desde } \\
\text { 2010. Fez primeiramente o } \\
\text { curso de Bacharelado e } \\
\text { depois concluiu a } \\
\text { Licenciatura concomitante } \\
\text { com o Mestrado. Fez } \\
\text { doutorado em física. }\end{array}$ \\
\hline
\end{tabular}

Tabela 7. 1 - Perfil dos docentes entrevistados

Para a entrevista, definimos quatro blocos temáticos dentro dos quais se constituíram as perguntas e respostas. O primeiro bloco diz respeito ao conhecimento do entrevistado, bem como seu posicionamento em relação às diretrizes, em especial sobre a questão da separação que se 
estabelece, nos cursos de formação de professores, entre conhecimento específico e conhecimento pedagógico. O segundo bloco pretendeu investigar a prática concreta do professor e a relação dessa prática com o seu discurso sobre a necessidade, ou não, de integrar o aprendizado dos conteúdos com o outros aspectos. Um terceiro bloco visava tentar perceber em que medida a instituição assumiu papéis no processo. Em um último bloco tentamos mapear possíveis relações das práticas e representações com as histórias pessoais desses docentes. O roteiro da entrevista segue no Anexo C.

$\mathrm{Na}$ análise das entrevistas foi utilizada a Análise de Conteúdo (Bardin, 2008), tomando como unidade de análise os temas das respostas, reorganizando-os e sistematizando-os. Também em dado momento, reagrupamos as unidades por sujeito entrevistado, procurando retomar elementos complementares.

\subsection{Dimensões de Análise}

Buscando alguma forma de ressonância entre os elementos teóricos que construímos ao longo do trabalho e uma realidade concreta formadas por prática reais pretendemos encontrar novos indícios e caminhos.

$E$ no sentido de construir uma ponte e estabelecer possibilidades de diálogo entre teoria e prática delimitamos três diferentes dimensões de análise.

A primeira dimensão de análise consiste na Dimensão do Currículo. Nessa etapa buscaremos explorar os discursos oficiais presentes nos documentos pertinentes, as características da instituição na qual se instaura o currículo em questão e as relações aí imbricadas.

Em seguida passaremos à segunda dimensão de análise: a Dimensão da Prática e dos Saberes dos Professores. Aqui buscaremos indícios que nos permitam inferir considerações acerca dos saberes dos

professores, ou seja, sobre como esses professores pensam o "ser professor". Buscaremos também identificar, principalmente a partir das falas dos docentes, elementos que dêem indícios sobre suas práticas.

Por fim trataremos da Dimensão dos Processos de Construção, na qual faremos uso do aporte teórico trazido por Goodson (2008) das "biografias de protagonistas". Buscaremos, nessa etapa, construir um 
conhecimento acerca das crenças e missões pessoais dos docentes envolvidos na pesquisa e a correlação desses elementos com o currículo e com as práticas em questão, bem como, com os movimentos atuais de mudança relacionados à formação de professores.

\subsubsection{Dimensão do Currículo}

Nossos estudos sobre currículo nos levaram a problematizar algumas concepções referentes à organização e seleção dos saberes em um projeto de ensino. Dentre os elementos constitutivos do currículo chamamos a atenção para a existência de um projeto formativo e de regulamentações oficiais. Exploraremos nessa etapa de pesquisa a questão do projeto formativo identificado em nosso caso referência e as questões que permeiam essa dinâmica.

Nessa dimensão trataremos, portanto, de aspectos mais ligados ao currículo formal propriamente dito e suas relações com aspectos institucionais. Nesse sentido exploraremos as características específicas da instituição, as condições que permitiram a existência do curso e do currículo, e analisaremos o discurso veiculado por meio dos documentos oficiais.

O Instituto Federal de Educação Ciência e Tecnologia de São Paulo - IFSP é uma instituição federal, pública, vinculada diretamente ao Ministério da Educação.

Como Escola de Aprendizes e Artífices, criada em 1909, teve seu projeto voltado para a formação de operários e contramestres. Nos anos de 60 a 90, como Escola Técnica Federal de São Paulo, formou técnicos de nível médio.

No final dos anos 90, com a reforma da Educação Brasileira, foi implantada uma nova proposta pedagógica em que foi definida, entre outras características, a separação entre o ensino de caráter mais geral, propedêutico, e a educação profissional, além da indicação para a verticalização da oferta de ensino. Em 18 de janeiro de 1999, por meio de um decreto presidencial, a antiga Escola Técnica Federal de São Paulo, fundada em 1909, tornou-se o Centro Federal de Educação Tecnológica de São Paulo (CEFETSP). A partir do ano 2000, já consolidada sua transformação em Centro Federal de Educação Tecnológica, houve a remodelação e a expansão 
da oferta de ensino da instituição.

Os decretos 3276 de 06/12/99 e 3462 de 17/05/00 autorizaram os CEFETs a sediar cursos de formação de professores para as disciplinas científicas da educação básica. No $2^{\circ}$ semestre de 2001, é criado o Curso de Licenciatura em Física do CEFETSP, o primeiro curso Superior de ensino da instituição.

Em 29 de dezembro 2008, o CEFETSP, por ação ao plano de reordenação da Rede Federal de Educação Tecnológica, aderiu ao status de Instituto Federal, transformando-se no Instituto Federal de Educação, Ciência e Tecnologia de São Paulo (IFSP). Os Institutos Federais consolidam a característica de oferecer ensino médio integrado (ensino médio em um dos turnos e ensino técnico em outro), cursos superiores de tecnologia, e licenciaturas. Hoje o IFSP possui, além das licenciaturas, nove cursos superiores de tecnologia e três cursos de engenharia. Depois da licenciatura em Física, foram criados os cursos de licenciatura em Geografia, Matemática, Ciências Biológicas e Química. A instituição oferece, ainda, treze modalidades de cursos técnicos, a modalidade de nível técnico integrado com nível médio e cinco cursos de pós-graduação lato sensu.

A iniciativa para a criação do curso de licenciatura do IFSP veio inicialmente de um grupo de professores da área de Física que davam aula no Ensino Médio regular. É interessante destacar que na estrutura do então CEFETSP foi constituída uma Coordenação de curso e um colegiado formado pelos professores responsáveis pela idealização e pela execução inicial do projeto.

Há três características bem peculiares no Curso de Licenciatura em Física do IFSP que nos parecem relevantes. A primeira diz respeito ao fato de que, a iniciativa para a criação do curso partiu de um grupo de então professores do Ensino Médio. A segunda é a vocação histórica da instituição, que é voltada à formação profissional. E, por fim, a terceira, diz respeito ao fato de não existir, nem de ter sido instituído em algum momento, uma área específica de educação. O que se consolidou foi a Coordenação do curso de Licenciatura em Física, responsável por todas as disciplinas do curso e pela alocação dos docentes nos espaços curriculares.

A época da criação do curso também é peculiar, visto que ele 
nasce quase de forma simultânea às "Diretrizes Curriculares Nacionais para a Formação de Professores da Educação Básica" e tem seu Projeto Político Pedagógico já desde o início em consonância com essa exigência legal.

Do grupo inicial de professores que idealizaram o curso nenhum se encontra mais no IFSP. O corpo docente atualmente é composto em sua maioria de professores que ingressaram por concurso público de provas e títulos, a partir de 2002.

Não foi possível entrevistar nessa pesquisa nenhum dos professores idealizadores do curso. Um relato de pesquisa e alguns fragmentos de entrevistas, que constituem registros da época em que o curso foi criado, podem ser encontrados no trabalho de Santos (2004).

Segundo Santos (2004) uma reforma do ensino técnico que veio a partir do decreto 2208/97, projetava a extinção do Ensino Médio em escolas técnicas e CEFETs. Embora isso nunca tenha chegado a acontecer e que o referido decreto tenha sido revogado pelo decreto 5154/2004, essa perspectiva fez com que um grupo de professores muito atuantes no Ensino Médio daquela própria instituição buscassem outras alternativas naquele momento.

A insatisfação desse mesmo grupo de professores com 0 próprio modelo do Ensino Médio a maneira como ele estava acontecendo também foi ingrediente na construção do curso de licenciatura. A perspectiva de discussão trazida pelas novas diretrizes do MEC para o Ensino Médio acabou culminando na formação de um "grupo piloto", que foi reconhecido inclusive institucionalmente, e se dedicava à pesquisa da interdisciplinaridade (SANTOS, 2004).

A ideia da licenciatura surgiu logo que os CEFETs foram autorizados a oferecer cursos dessa natureza. Apesar desse grupo ter como integrantes professores de diversas áreas, a existência de uma enorme demanda por professores de física na cidade de São Paulo e o fato de que boa parte dos professores pioneiros do grupo piloto serem da área de física e matemática, contribuiu para fomentar a ideia embrionária de um curso de Licenciatura em Física (ibidem).

Esses mesmos professores fizeram uma proposta de currículo. Santos (2004) relata que um dos pilares da construção do currículo foi as 
"Diretrizes Curriculares para Formação de Professores da Educação Básica". A licenciatura que estava sendo ali pensada tinha como marca inovadora a ideia de que embora sendo um curso de Licenciatura em Física, se contemplasse um professor que:

(...) soubesse mais do que física, que se interessasse pelas questões pedagógicas, que entendesse a educação como um processo político, cultural, que relacionasse a física com a cultura, com a história, com outras áreas de conhecimento, com outras ciências, com a tecnologia." (SANTOS, 2004, p.92)

Outro dado interessante trazido por esse relato é que a participação do MEC foi mínima, uma vez que só concedeu a autorização. Nenhuma verba adicional foi repassada ao CEFETSP para a implementação desse curso (SANTOS, 2004, p. 93).

Ainda referente à caracterização da situação na qual se originou esse curso de licenciatura é valido destacar algumas considerações dos sujeitos envolvidos sobre o fato de estarem propondo um curso de licenciatura fora da universidade. Transcrevemos a seguir dois trechos de entrevistas retirados do relato de Santos (2004):

Há uma grande preocupação na formação dos professores na [universidade] pública e nas particulares. A gente sabe que hoje o professor não está sendo bem formado em lugar nenhum. Eu tenho isso claro

(Trecho de entrevista com um dos professores fundadores do curso, transcrito em Santos (2004) p. 96)

Uma colega, professora de História da Didática lá da Faculdade de Educação, fez algumas críticas à formação dos professores no CEFET. E aí eu penso que as pessoas têm uma coisa muito rançosa que é pensar que só a universidade produz saber, conhecimento e que forma bem. Não é bem assim. Eu acho que a gente tem que quebrar esse pensamento. Eu acho que nem é um pensamento, é mais que um pensamento, é uma ideologia da aristocracia das universidades públicas do país de que a relação ensino-pesquisa só existe na universidade, nas boas universidades, nas universidades padrão público desse país. A universidade parece ser um bloco monolítico que não pode ser atacada em nenhum momento (...). Eu entendo que toda a instituição que trabalha com ensino ela universaliza o saber e o conhecimento, então [a licenciatura] não é propriedade privada das universidades. (Trecho de entrevista com um dos professores fundadores do curso, transcrito em Santos (2004) p. 95)

A Licenciatura em física foi implementada e recebeu sua primeira turma no segundo semestre de 2001. O curso está estruturado em oito semestres, incluindo práticas de ensino, atividades curriculares, acadêmicas e culturais e estágio de ensino, totalizando uma carga horária de 
três mil horas. Da carga horária total, quatrocentos e cinco horas são destinadas ao estágio supervisionado desenvolvido em concomitância com alguns componentes curriculares a partir da segunda metade do curso, como reza a legislação.

A partir de 2002 novas contratações de professores foram efetuadas visando atender à demanda da licenciatura que iria atingir seu pleno funcionamento com oito semestres em curso. Dado uma tendência de todo o CEFETSP de expansão da oferta de Ensino Superior, as novas contratações contemplaram mestres e doutores, da área de Ensino de Física e da área de Física. Pelo fato de a instituição oferecer também Ensino Médio, todos os contratados da área de física têm que cumprir a exigência de possuir licenciatura.

O curso é oferecido no período matutino. Os componentes curriculares do curso pretendem proporcionar ao futuro professor domínio de conteúdos específicos de física clássica, moderna e contemporânea, bem como suas articulações com outras áreas do conhecimento científico e tecnológico aliados à formação didática e pedagógica. A matriz curricular do curso foi:

concebida de modo a articular, no processo de formação do futuro professor, os conhecimentos didáticos, pedagógicos, os específicos em Física e aqueles relacionados à interface da Física com outras áreas da ciência e da cultura (Biologia, Química, Astronomia, Ciências da terra, História, Linguagem, Filosofia e Tecnologia). (CEFETSP, 2003).

Segundo o texto inicial disponível na página do curso na internet:

Nossa perspectiva de Licenciatura se diferencia de outros cursos que tratam a Licenciatura como uma complementação do Bacharelado em Física, ou de outros que tratam a Licenciatura em Física como um curso básico de formação do educador com uma complementação na área da Física. Ambas as concepções nos parecem falhas, pois 0 profissional do ensino da Física precisa de um amplo conhecimento conceitual e experimental da Física ao mesmo tempo que precisa de um amplo conhecimento de questões da educação. Desta forma propomos aos nossos alunos em todos os espaços curriculares de nosso curso que os conhecimentos físicos estejam permeados pelas implicações e questões pedagógicas envolvidas no ensino da Física, e assim nos afastamos dos cursos de Bacharelado em Física tanto quanto dos cursos de Pedagogia, atuando especificamente em nossa área que é 0 ensino da física. (Disponível em http://www.cefetsp.br/edu/lif/nossocursointeressados.htm, acesso em 20/01/2012) 
A matriz curricular desse curso se apresenta de forma diferenciada, evidenciando os eixos articuladores do currículo e as competências a serem desenvolvidas, exatamente como proposto nas "novas diretrizes para formação de professores". Vários trechos do texto do projeto são transcrições do texto dessas mesmas diretrizes. A matriz dos espaços curriculares e das competências segue no Anexo D.

É interessante destacar que no Projeto do curso não há menção a disciplinas em si e sim "a aspectos disciplinares do curso que integram os conhecimentos específicos de natureza científico-cultural, a prática como componente curricular, as atividades acadêmico-científicoculturais e o estágio supervisionado" (CEFETSP, 2003. p.8). Segundo o texto são esses elementos que constituirão os espaços curriculares.

O objetivo do curso segundo o projeto político pedagógico é o de:

\begin{abstract}
Formar um educador comprometido com uma educação científicotecnológica de qualidade, derivada de uma leitura crítica do mundo, dos atuais sistemas de ensino públicos e privados, que contribua para uma transformação social que possibilite a igualdade de oportunidades para todos os cidadãos (CEFETSP, 2003, p. 16).
\end{abstract}

Há ainda no projeto uma crítica explícita aos cursos "tradicionais" de formação de professores, os quais, segundo o texto, revelam "o pressuposto de que a competência profissional se faz pela integração de diversos saberes isolados" (CEFETSP, 2003, p. 19). Nesse sentido e adotando postura que contraria essa dissociação curricular, o que se propõe é, "seguindo o espírito das Diretrizes, uma articulação dos saberes, voltada à capacitação político-pedagógica do futuro professor" (CEFETSP, 2003, p. 19). Destacamos ainda o trecho:

A idéia básica é que o currículo e os espaços curriculares sejam
concebidos como auto-similares, ou seja, as competências que
definem o desenho curricular são norteadoras, também, da
constituição dos espaços curriculares (CEFETSP, 2003, p. 19).

O fato do projeto político pedagógico do curso estar em forte ressonância com as Novas Diretrizes pode ser interpretado da perspectiva de que o grupo de professores que elaborou a proposta tinha uma forte identificação com essas propostas.

Os princípios para a constituição do currículo e dos espaços 
curriculares foram sistematizados em: contextualização do conhecimento, a prática reflexiva, interdisciplinaridade, homologia de processos e ainda os eixos delineados para a organização da matriz curricular pelas Novas Diretrizes Curriculares para a Formação de Professores da Educação Básica: eixo articulador dos diferentes âmbitos de conhecimento profissional, eixo articulador da interação e comunicação e do desenvolvimento da autonomia intelectual e profissional, eixo articulador entre disciplinaridade e interdisciplinaridade, eixo que articula a formação comum e a formação específica, eixo articulador dos conhecimentos a serem ensinados e dos conhecimentos educacionais e pedagógicos que fundamentam a ação educativa, eixo articulador das dimensões teóricas e práticas.

Quanto à "Prática de Ensino como Componente Curricular" o projeto do curso especifica que:

O desenho curricular do curso de Licenciatura do CEFETSP prevê a articulação das práticas de ensino, das atividades acadêmicocientífico-cultural e do estágio supervisionado com os espaços curriculares afins. Com relação às práticas de ensino e as atividades acadêmico-científico-cultural, os espaços curriculares prevêem uma carga horária e propostas de trabalho a serem desenvolvidas conjuntamente e de forma articulada com as atividades acadêmicas de conhecimentos específicos. Assim, é o professor responsável pelo espaço curricular que gerencia a realização das práticas de ensino e das atividades científico-cultural, as quais compõem conteúdos curriculares que são formalizados e avaliados pelo mesmo. A partir da segunda metade do curso, principalmente as práticas de ensino encontram-se também articuladas aos estágios supervisionados. Optou-se, desse modo, pela não criação de espaços curriculares específicos voltados à prática de ensino ou ao estágio, a fim de manter-se o caráter de articulação entre a formação do professor numa área de conhecimento específico e sua formação pedagógica mais geral, bem como entre as dimensões teóricas e práticas das mesmas (CEFETSP, 2003, p. 26).

Quanto ao "Estágio Supervisionado" o projeto do curso explana que:

Em cada semestre do curso, o estágio promove a articulação entre os assuntos tratados nos espaços curriculares e a vivência profissional, mediados pelo professor responsável pelo espaço curricular nos horários de orientação coletiva juntamente com a atuação individual do professor orientador, que pode ser o mesmo responsável pelo espaço curricular ou pode ser um professor designado para o horário de orientação individual do espaço curricular na atribuição de aulas. Além dos trabalhos centrados nos espaços curriculares o estágio ainda elabora um relatório final com reflexões que indiquem a articulação dos conhecimentos e das vivências do estagiário nos diversos espaços curriculares e nas diversas horas de estágio supervisionado, encaminhado juntamente com todos os documentos e relatórios individuais ao Supervisor de estágio para 0 
acompanhamento e a validação das horas de estágio (CEFETSP, 2003, p. 27) .

Notamos então que nos espaços destinados à prática e aos estágios há uma clara preocupação de articulação com as atividades de outras naturezas previstas no curso. Esses espaços, portanto, também se apresentam em um formato, em certo sentido, inovador.

Pudemos notar ainda outra perspectiva institucional, embora com caráter um pouco mais oculto. É possível perceber que a instituição não ofereceu resistências a esse curso em seu formato inovador. $O$ projeto foi apresentado e aprovado em várias instâncias internas da instituição. Assim, mesmo que a instituição não se identifique de forma geral com cursos de formação de professores, também não ofereceu resistências. Isso é um elemento fundamental, ainda que não suficiente, que possibilita a instauração desse movimento que incorpora uma mudança.

Já nas falas dos sujeitos sobre o papel da instituição, além do fato da instituição não impor resistências explícitas como indica a análise do Projeto Político Pedagógico do curso existem outros elementos que indicam a instauração de um "segmento interno de mudança" (Goodson, 2008).

É possível perceber que, as diretrizes têm poder de indução de modificações, até mesmo porque atuam com o poder da legislação. Mas, isso não acontece por meio dos mecanismos ou encaminhamentos apontados no corpo da legislação, que apontam um caminho de realizações institucionais. Ao contrario, talvez esses mecanismos fiquem reduzidos ao espaço burocrático de resposta institucional formal.

Isso porque a instituição não participa nem incentiva, porque ela mesma não valoriza a formação de professores. Mas as políticas públicas na área promovem o desenvolvimento de projetos dessa natureza na instituição, que acaba por aderir levada por razões estratégicas mais amplas. E o faz pela própria história da instituição, tanto como escola media técnica, como por suas aspirações em ganhar status como escola superior. Mesmo que esse processo se dê permeado por práticas arraigadas na instituição, que não valorizam o trabalho docente de seus professores, e por outro lado, imersa em um contexto social mais amplo onde prevalece a desvalorização da profissão professor, a constituição de um curso voltado à formação de 
professores tem garantidas as condições para se instaurar.

Isso se vê refletido nas seguintes falas dos sujeitos:

Eu acho que ela, na verdade a direção da instituição é uma direção muito vinculada às pessoas das áreas técnicas e elas não dão valor... não valorizam o ensino! Nem o ensino dentro da própria instituição muito menos o da formação de professores $(A)$

E, por exemplo, você vê, na opinião deles, se lá tivesse tido a chance de formar um curso que não de licenciatura eles teriam formado. $E$ a gente que fica na área da formação básica, a única chance de ir para o curso superior é o curso de licenciatura! O governo claramente não quer engenharia (...) ele quer o quê? LICENCIATURA! (B)

Eu acho que o interessante é a estrutura. Acho que a instituição, ela não se preocupa muito com isso e essa é que é a vantagem. No fim fica nas nossas mãos essa questão aí, essa construção. Essa é uma vantagem. (D)

Há outra instância de nossa análise que diz respeito a uma característica institucional específica dos Institutos Federais (IFs) que em nossa hipótese tem a ver com a dinâmica diferenciada do curso de Licenciatura em Física que surge no IFSP. O modelo de licenciaturas em IFs (antigos CEFETs) é diferenciado como fica explícito na seguinte fala:

Agora existem projetos muito interessantes, do ponto de vista do que é uma licenciatura, em CEFETs ... então assim, Os CEFETs trouxeram um novo modelo que não é o $3+1$. (C)

Parece-nos que esse modelo "novo", mais próximo à perspectiva que nós lemos também nas "Novas Diretrizes Curriculares para Formação de Professores da Educação Básica", de romper com o modelo fragmentado dos saberes na formação, tem relação estreita com o fato de o IF não apresentar uma instância institucional responsável pela parte pedagógica do curso e outra responsável pelas disciplinas de conteúdo específico. Sobre essa estrutura diferenciada da instituição nossos entrevistados elencam prós e contras:

pela ausência da faculdade de educação, então nós temos professores aí que tem uma formação em ensino, mas nesse sentido que é a nossa área de formação, ensino de física $(A)$

...Você já pensar esse corpo aí de conhecimentos, que estariam mais dentro dos saberes educacionais, pedagógicos, que eu não sei se são de fato, mas você já traz para o domínio da física. Então isso eu acho bacana.(B)

agora sem dúvida por ser uma instituição onde você não tem nucleados seus institutos, por exemplo, a gente tem aqui uma área de física (...)tinham engenheiros, tinham biólogos, tinham geógrafos, 
filósofos... E esses professores atuavam com a gente nos cursos. (...)Mas eu acho que assim, que aqui se faz um curso muito interessante, que tem algo a mostrar, de que é possível você fazer isso. (C)

...eu acho que as disciplinas pedagógicas mais específicas elas as vezes correm o risco de cair num senso comum, de perder aí uma carga de leitura, de vivência mesmo que a gente não, que os professores da faculdade de educação costuma ter e que a nossa formação por estar mais vinculada a uma área de conhecimento é menor. (...) (A)

Agora por outro lado você vê cada licenciatura se isolando e pensando um conjunto de saberes... (B)

Agora, é uma coisa muito difícil de se fazer. Acho que não tem como se iludir não! Mesmo porque há muitas pessoas que não acreditam que você possa fazer isso. (C)

Sim, eu acho que sim. Aqui você não tem muito essa diferenciação de um departamento entre aspas, pedagógico e outro de física. E no fundo o curso é desenvolvido pela própria área, no caso os professores de física. Acho que isso permite então pensar um pouco o curso de uma maneira mais específica, mais da área e não em termos de departamentos específicos, o que acaba separando um pouco as disciplinas, e a maneira como você aborda isso. (D)

Eu não sei como é que ficou nos outros lugares, eu tenho a impressão que todos agora ou quase todos seguem o modelo que nós estamos usando, quer dizer, tem uma área de física, uma área de matemática, quer dizer, tem as áreas específicas que eventualmente abrem seus cursos de licenciatura. (E)

Fica em evidência o fato de que embora essa estrutura institucional diferenciada tenha também perigos, há uma tendência de inovação presente, na forma como os conhecimentos de física e os conhecimentos pedagógicos estabelecem relações. Isso é possibilitado pelo fato de não haverem instâncias específicas nucleando as áreas de conhecimento, pelo fato dos docentes do curso como um todo serem responsáveis por todas as disciplinas, e pelo fato de que esses docentes de alguma forma se sentem minimamente competentes tanto para fazer discussões educacionais quanto para falar de física. Isso fica bem exemplificado na fala onde o entrevistado comenta que já foi questionado sobre o fato de não ter na grade curricular os cursos específicos de educação.

“... porque não há aqui na nossa grade um curso de psicologia da educação. No entanto a psicologia da educação está presente em Escola e Sociedade, ela está presente na Epistemologia, e está presente em vários outros cursos quando se discute como é que o indivíduo toma as suas decisões, como é que ele vai crescendo modificando as suas estruturas de pensamento, e aí então como ele age cognitivamente ao longo de sua história e isso está presente nos 
cursos. Então os modelos da psicologia. Então não é que não exista. Ele só não existe enquanto uma única área de conhecimento. Ele está junto de outras discussões. E nessas discussões a gente sempre entende que o ensino da física tem que estar presente. Então na epistemologia da ciências é bacana discutir ela do ponto de vista filosófico. Mas há que se fazer isso para a ciência Física. Porque é essa ciência que a gente aprende. (C)

Assim podemos elencar que há uma mudança que se realiza na possibilidade de se criar um curso de Licenciatura nesses moldes distintos. A política de incentivo a novos cursos de licenciatura do governo constituiu o arcabouço externo de apoio e patrocínio, que tornou um ambiente, inicialmente não propício por si só, fértil à implementação de um formato inovador. Apesar da instituição não se identificar com a formação de professores, é precisamente a sua estrutura, que não contempla um núcleo específico de Educação que acaba obrigando um núcleo de pessoas com formação não especificamente educacional a assumir a discussão pedagógica, mesmo que em seu restrito âmbito, rompendo com a separação entre conhecimento pedagógico e conhecimento específico.

É preciso, no entanto, enfatizar que a estrutura institucional parece permitir que a inovação aconteça, uma vez que os agentes envolvidos tiveram e têm certa autonomia, e não encontraram resistências. Mas o desenho institucional por si só nada pode garantir, como fica claro nessa fala do docente $\mathrm{E}$ :

\footnotetext{
Enfim, eu acho na verdade que a influência é pequena. Na minha opinião, bem por alto assim, eu não tenho muita base pra dizer isso. Agora, porque que eu acho isso? Porque nas outras licenciaturas, na matemática, na química e na biologia... eu não vejo esse pessoal agindo da mesma maneira que a gente tem agido aqui, e qual que é a diferença? Não tem diferença porque a estrutura é a mesma! A diferença é de onde veio o pessoal, quem são essas pessoas, e qual é o compromisso delas com esse curso. (E)
}

No que concerne a dimensão do currículo podemos concluir que o curso tem um formato diferenciado e inovador. A própria história da criação do curso nos aponta caminhos pouco convencionais. Destacamos ainda um formato diferenciado em relação ao desenho institucional que se diferencia pela não existência de um departamento específico de educação responsável por uma parte do currículo da licenciatura.

A análise desses aspectos de cunho mais oficial e institucional, no entanto, não esgota as possibilidades de se pensar o 
currículo. Como tentamos argumentar ao longo de todo o trabalho a realização prática e concreta de um projeto de ensino envolve muitos outros elementos. $\mathrm{E}$ é nesse sentido que buscaremos compreender outras dimensões, dentre as quais a dimensão das práticas e dos saberes dos professores, que são os efetivos responsáveis pela realização do projeto formativo em questão.

\subsubsection{Dimensão da Prática e dos Saberes dos Professores}

Nessa etapa do trabalho buscaremos explorar relações que nos deem indícios sobre os saberes dos professores por meio das falas desses docentes. Apropriamo-nos então de indícios indiretos que possam sinalizar as formas que os professores vêem os saberes que permeiam o seu trabalho. Nesse sentido, assim como fizemos ao longo de boa parte dessa pesquisa como um todo, podemos fazer correlações entre a forma como se apresentam os saberes e as concepções de professor e de educação aí imbricadas.

Nesse sentido destacamos o objetivo de compreender um pouco mais a fundo como os docentes formadores pensam o "ser professor" e a formação de professores.

Como nosso objeto de estudo em âmbito mais geral trata dos saberes e mais propriamente da articulação que pode se estabelecer entre eles estamos também à procura, de certa maneira, de formas práticas de articulação.

Destacamos então para essa etapa da análise trechos em que os sujeitos falam sobre seus fazeres práticos a partir dos quais pudéssemos inferir sobre as visões que esses professores têm sobre os saberes que permeiam sua atividade em um curso de licenciatura, ou seja, cuja finalidade é também formar professores.

Nessa análise tentamos identificar tanto a questão do entendimento e da clareza quanto à finalidade de um curso de licenciatura em física quanto a questão da presença e da articulação dos saberes específicos e dos saberes pedagógicos no seio do projeto de formação.

Definimos então a partir dos trechos analisados três marcos de concepções sobre os saberes: o da física como conhecimento dado (desarticulação), o da física articulada com os saberes pedagógicos na 
perspectiva da racionalidade técnica e o da física articulada de forma crítica.

O marco da física como conhecimento dado seria a expressão de um grau elevado de desarticulação no qual se pensa o ensino de física na licenciatura de forma estanque, independente de qual uso se fará dele depois. Assim não existiriam formas de articulação entre saber específico e saber pedagógico.

O marco da física articulada com os saberes pedagógicos na perspectiva da racionalidade técnica é a expressão da concepção que leva em consideração a finalidade de um curso de licenciatura, pois, ao se ensinar física, já existe a preocupação com as estratégias e metodologias de ensino. A discussão acerca de "como ensinar" se faz presente ao mesmo tempo em que se ensina a física em si. Nesse sentido estão presentes saberes de física e saberes pedagógicos de forma articulada, mas sobremaneira em sintonia com o paradigma da racionalidade técnica.

Já o marco que denominamos o da física articulada de forma crítica reflete uma concepção crítica que permite colocar as finalidades educativas em primeiro plano de maneira que o conhecimento da física se apresente desnaturalizado. Isso significa pensar saberes específicos e pedagógicos de maneira orgânica, problematizando o papel do professor e o papel dos próprios conhecimentos dentro da atividade educativa. É uma asserção às finalidades que permitiria pensar novas formas de articulação do próprio conhecimento e permite a desconstrução e a reconstrução de processos e práticas de acordo com os contextos.

O que verificamos ao longo da análise é que esses marcos não poderiam definir categorias de sujeitos mutuamente excludentes. Primeiramente porque um mesmo sujeito pode expressar mais de uma visão sobre os saberes e sobre as finalidades envolvidas. Depois porque até mesmo dentro de uma mesma unidade de análise (trecho da entrevista) existem estados híbridos ou intermediários.

Nesse sentido formulamos uma análise contínua e linear que vai de um extremo, que é a visão desarticulada a outro que é a visão crítica. $O$ marco da perspectiva articulada pela racionalidade técnica é o mediador desses dois extremos. Isso se encontra representado na figura 7.1 
A partir desse desenho foi possível enquadrar as unidades de análise em quatro grupos. O primeiro corresponde de forma clara ao marco da física como conhecimento dado e o segundo grupo corresponde ao marco da física articulada na perspectiva da racionalidade técnica.

Já um terceiro grupo identificado nas unidades de análise corresponde a um estado intermédio entre o marco da física articulada na perspectiva da racionalidade técnica e o marco da física articulada de forma crítica. São trechos que evidenciam uma preocupação de que os alunos da licenciatura reflitam sobre o ser professor, e que, portanto, vão além da racionalidade técnica, mas ainda sem questionar o conhecimento físico vinculado nos processos de ensino.

O quarto grupo consiste nas unidades de análise que se enquadram na física articulada de forma crítica.

No que concerne ao primeiro grupo de análise, alinhado com o marco da física como conhecimento dado, podemos citar algumas falas do entrevistado F:

Nós estamos ensinando professores de alguma coisa, de física por exemplo então tem-se que ensinar física pra eles. Matérias de física pra valer! $(\mathrm{F})$

Mas também tem uma hora chega um momento que eu desencano, eu tenho que assumir que eles tem que de qualquer jeito e às vezes eu toco a matéria, um bom tempo na aula, e esqueço que eu estou falando pra pessoas que vão ser professores, eu estou ensinando física. $(F)$

Eles tem que ser ensinados física como em qualquer curso de física, bacharelado ou licenciatura. E nem por isso eu vou ensinar num nível melhor ou pior. (F)

$O$ entrevistado $F$ parece tratar o que seja o conhecimento físico de uma forma trivial. Esse sujeito parece ser o único que ainda sustenta 
uma visão da física por si só.

O segundo grupo delimitado se coloca dentro do marco teórico da física articulada com os saberes pedagógicos na perspectiva da racionalidade técnica. Nesse sentido as falas contemplam uma visão do conhecimento de forma já articulada com as estratégias de ensino. Essa visão se alinha bastante com a perspectiva da didática específica e visões ainda tradicionais de currículo. São exemplos de falas dos sujeitos que destacam essa perspectiva:

Então a gente tenta trabalhar, por exemplo, com a construção de materiais experimentais de baixo custo em sala de aula, mas que o aluno, o licenciando pode usar na sala de aula dele, softwares usando simulações que eu também uso para discutir com o aluno a questão do conteúdo, mas também para discutir a utilização desse material em sala de aula. Um pouco com texto também, livros, revistas, são matérias que a gente tem usado e ao mesmo tempo eu tento refletir um pouco sobre o que é que é isso... (D)

Então eles teriam que apresentar uma atividade e discutir a física dela, e ela tinha que ter uma estratégia de ensino lá onde ela fosse atuar, por exemplo, o lúdico, fosse com o experimento, fosse com a história. (C)

Dessas falas podemos perceber uma defesa da importância de que o saber da física seja discutido já problematizando as estratégias de ensino. Trata-se de uma forma de articulação, embora ainda limitada ao como ensinar.

O terceiro agrupamento de unidades de análise se refere a uma categorização intermediária. Há um conjunto de falas que se situa além da racionalidade técnica, mas não atinge um nível crítico de questionamento em relação ao que é objeto de ensino. São falas que remetem a uma reflexão sobre o que é ensinar e ser professor. São exemplos de falas dos sujeitos que destacam essa perspectiva:

Eu acho que a gente consegue colocar a questão prática do ensino de uma maneira com muito mais presença do que outras instituições mais tradicionais. E nesse sentido ele acaba sendo um professor muito mais consciente do que ele pode e do que ele não pode em sala de aula. E quais os recursos, enfim, quais são as possibilidades que eles têm dentro da física. (D)

Então eu acho que aqui se buscou, no próprio plano né, de como era feito, de como os cursos eram desenvolvidos, juntar essa ideia de que você tem saberes específicos de uma área de conhecimento, ao mesmo tempo que você tem que conhecer didática, pedagogia, questões de psicologia da educação, questões da formação do 
professor, e que isso não se dá de forma separada, isso tem que ser feito de forma conjunta (C)

não é questão só de ele aprender a mecânica, aprender como é que eu ensino mecânica (E)

... eu acho que o nosso curso podia estruturar melhor o conhecimento da física do que o que ele estrutura mas eu acho que eles saem sabendo muita física... em algum sentido sabem mais física do que a física que eu saí sabendo... do ponto de vista de uma formalização da física eles saem sabendo muito menos mas do ponto de vista de uma experiência com os fenômenos... de um contato com os fenômenos físicos... talvez de um conhecimento mais superficial mas também mais amplo... acho. (A)

a maior parte das disciplinas que eu tenho dado tem sido pra Licenciatura em Física... e essencialmente disciplinas de física... mas de física nesse sentido que a gente está falando, que sempre pensa 0 que é a formação de professores ao mesmo tempo.. (A)

Eu diria que a gente tem que definir o que é que é saber física.(...) Quer dizer, um aluno que vem de um curso que é o três mais um vai certamente ser daqueles matemáticos assim, maior. Mas não necessariamente ele vai ter uma capacidade maior de ensinar aquela física ou de discutir os fundamentos daquela física. (E)

está tão imbuído que o currículo é aquele que qualquer coisa que você tenta propor diferente daquilo, o cara já se afasta, porque ele não quer, ele acha que, sei lá, de alguma forma, pra ele o currículo é o que é e não tem outra alternativa. Então você fala pro cara, ah, que tal colocar um pouco de física moderna aqui? (E)

Por fim temos o agrupamento das unidades de análise que se aproximam mais da perspectiva crítica, apresentando um saber de física pensado de forma mais orgânica com o saber pedagógico. Nesse caso consideramos que o saber de física se encontra desnaturalizado, o que possibilita mudanças na seleção e organização desse saber, levando em conta as finalidades de ensino em diferentes contextos. São exemplos de falas dos sujeitos que destacam essa perspectiva:

Não acho que eles saiam sabendo menos física não! Acho que só que falta essa discussão mais em cima de... eu acho que eles saem.... eles sabem a física dos livros textos, isso eu não acho que é um problema pra eles... o que eu to dizendo que eles saem menos articulados do que deveriam eu acho que é no sentido de... vamos propor uma física... vamos desorganizar isso aqui um pouco... vamos desorganizar o livro didático? (B)

Não pode-se discutir apenas física, e não pode-se discutir apenas as questões pedagógicas no ensino da física. As duas coisas estão imbricadas. Ao discutir física você tem que discutir como se ensina essa física né? E ao discutir como se ensina física, você tem que discutir os elementos se não você não tem sobre o que discutir. Está formando professores que tem esse entendimento, de que a ação dele não se desvincula do saber específico dele, de nenhuma forma. 
Não tem nenhum dos dois lados aí que é privilegiado. Eu não sou primeiro um professor pra depois saber física. Aqui, e isso é uma coisa que eu sempre deixei muito claro enquanto coordenador, aqui se formam professores de física, que precisam saber muita física, e precisam saber muito sobre educação. (C)

Discutir a própria questão do que é a física, do que é ensinar física, ensinar o que e pra que... Isso sempre teve presente aí nos meus cursos da física, que tinham o foco mais voltado pra física, mas que discutiam toda essa problemática do professor, porque você tem que fazer escolhas e essas escolhas não são ao acaso. Elas são permeadas por uma postura ideológica sua que você quer fazer, de que transformação você quer que ocorra no mundo, ou que transformação você não quer que ocorra o mundo. (C)

E está equivocado porque no ensino o objeto de estudo não é nem por um lado ciência básica, nem tão pouco é a pedagogia. Ensino é uma união dessas duas coisas que é o nosso objeto de estudo. (C)

Decorrente de uma série de idéias que nós tivemos, de modificar, e fazer diferente no ensino médio. Então a gente está pondo isso em prática, então nosso ensino médio por exemplo está começando por eletricidade. Começa com força elétrica, depois passa pra carga eletrostática, então o ensino médio está começando dessa forma. $O$ primeiro ano é eletricidade e eletromagnetismo. E aí então esse professor falou: Por que é no curso médio a gente não faz do jeito certo? Aí eu falei: mas qual é o jeito certo? Aí ele falou com mecânica e tal. Bom aí eu não ia pegar e dar uma patada assim, mas eu disse que nunca vi alguém me mostrar que existe um jeito certo." (E)

Essa análise nos mostra primeiramente que podemos encontrar em um caso concreto referente a práticas reais elementos diferenciados dos saberes dos professores em que é possível encontrar ressonâncias com as formas teóricas de apreensão dessas questões anteriormente exploradas.

É possível perceber que mesmo sem serem perguntados diretamente sobre suas concepções os docentes revelam elementos ao falar de suas práticas.

Podemos perceber que no caso por nós analisado há consideráveis indícios de uma compreensão crítica acerca dos saberes do professor pelos professores formadores. Apenas um docente explicitou resquícios de uma imagem da física de forma completamente desconexa e apartada das finalidades de um curso de licenciatura.

Que a finalidade do curso é a de capacitar profissionais para ensinar física no Ensino Médio parece ser um aspecto levado muito em consideração pelos formadores. Em alguma proporção do ponto de vista da racionalidade técnica, mas de modo que não é o discurso e sim a prática que 
incorpora elementos dos procedimentos de ensino que o futuro professor vai ter.

Por outro lado aparecem também reflexões que inclusive questionam o que seria esse fazer da técnica. Nesse sentido destacamos uma gama de unidades de análise que representam quase que um caminhar em direção a uma compreensão mais crítica.

E a visão crítica de fato se materializa, também, em algumas falas. Nessas unidades de análise os sujeitos dão indícios de uma visão de conhecimento que entende a física de forma desnaturalizada e os saberes dos professores de forma orgânica e alinhada a finalidades educacionais.

Todas essas características podem nos levar a nos perguntarmos ainda quais são os processos que levaram nossos sujeitos pesquisados a construírem e praticarem essas visões sobre os saberes dos professores.

\subsubsection{Dimensão dos Processos de Construção}

Assumindo que há um papel importante em qualquer processo inovador que é ligado ao aspecto institucional e que "a aceitação da mudança só ocorre com uma mudança interior nas crenças e planos das pessoas." (Goodson, 2008, p.41), vamos nessa etapa de pesquisa tentar entender melhor o que levou os nossos sujeitos entrevistados a assumirem as posturas que pudemos identificar.

Como já mencionado no início do capítulo, nossa escolha dos entrevistados se balizou pela busca de diferentes perfis de docentes, com histórias profissionais e de vida diferenciadas.

A análise da dimensão curricular nos apontou a existência de um desenho institucional que possibilitou a existência de um curso inovador, mas que por si nada parece garantir. Assim para uma melhor compreensão dos elementos que propiciaram esse formato inovador de curso foi necessário concentrar esforços no entendimento de porque algumas pessoas assumem para si essas discussões e aceitam o desafio de impregnar suas práticas de reflexões educacionais.

Tomando como referência as discussões sobre mudanças curriculares, particularmente as propostas por GOODSON (2008), buscamos 
contemplar dentre outras, a dinâmica através da qual a proposta inicial do curso de licenciatura foi sendo implementada.

Para isso, optou-se por uma ênfase nas biografias de protagonistas, privilegiando suas percepções, vivências e práticas.

Analisando os resultados com a perspectiva das abordagens teóricas dos capítulos anteriores e com a contribuição das discussões sobre mudanças curriculares propostas por Goodson (2008), buscaremos compreender quais são as crenças e missões pessoais desses sujeitos.

Nesse sentido tentaremos compreender um pouco da "história de vida" de nossos entrevistados, buscando indícios de crenças e missões pessoais que esses sujeitos trouxeram para o interior da proposta inovadora.

O sujeito entrevistado $A$ tem formação de bacharelado e mestrado na área de física. Tinha um envolvimento no movimento estudantil e uma ideia que divergia da de seus colegas mais ligados a áreas de pesquisa, em relação valorização do professor. Foi fazer licenciatura porque realmente queria dar aulas. Decidiu que não queria seguir a área de pesquisa em física e optou por ser professor. Fez concurso para o IFSP e logo começou a atuar na licenciatura, porque gosta dessa área. Sempre teve interesse pelo Teatro, começou uma faculdade de artes cênicas, e tem a motivação de trazer a presença corporal do teatro para a formação de professores.

$O$ sujeito entrevistado $B$ se formou bacharel em física e foi fazer mestrado em Ensino de Física. Isso porque conheceu o GREF $^{10}$ e a maneira diferenciada como esse projeto organizava o conteúdo de física despertou o interesse pela área de ensino. Posteriormente fez o doutorado na área de educação. Fez concurso no IFSP e afirma que o emprego no IFSP oferece liberdade, pesquisa e tem a vantagem da dedicação exclusiva.

O sujeito entrevistado $C$ começou a cursar o bacharelado e começou a dar aulas por uma questão financeira. Apaixonou-se pela idéia de ensinar e mudou para o curso de Licenciatura. Ao se formar começou a se interessar também por investigar e foi fazer mestrado em Ensino de Física, investigando a questão das linguagens e das mídias audiovisuais. Continuou dando aulas, foi professor substituto e saiu porque naquele momento viu que

\footnotetext{
${ }^{10}$ GRUPO DE REELABORAÇÃO DO ENSINO DE FÍSICA - Proposta de ensino para o Ensino Médio elaborada por professores da USP em parceria com professores da escola pública.
} 
não haveria espaço para ele na Licenciatura. Dois anos depois passou no concurso e voltou como professor efetivo. Depois de seis meses foi eleito coordenador do curso.

O sujeito entrevistado $D$ fez primeiramente o bacharelado e durante a realização do seu mestrado em física, concluiu a licenciatura. Fez concurso e deu aulas na rede estadual por algum tempo. Embora sua atividade docente fosse muito ligada a uma necessidade financeira, logo percebeu que o modelo tradicional de ensino, com fórmulas e a reprodução do que estava nos livros não funcionava muito bem na prática, e buscou inovar em suas aulas, e acabou refletindo sobre questões educacionais. Fez concurso para o CEFETSP, depois de terminar seu doutoramento em física, sem saber da existência do curso de licenciatura, mas encarou isso como uma grata surpresa.

O sujeito entrevistado $E$ também fez primeiramente 0 bacharelado e durante a realização do seu mestrado em física, concluiu a licenciatura. Fez doutorado e pós-doutorado na área de astrofísica, e prestou o concurso no CEFETSP, por opção de emprego público em sua área. Já sabia da existência do curso de licenciatura em Física e lhe agradou a ideia de dar aulas no Ensino Superior. Atualmente está se iniciando na área da pesquisa em Ensino de Física, uma vez que o CEFETSP não ofereceu muita possibilidade de desenvolvimento da pesquisa em física e porque há um grupo de ensino se consolidando na instituição.

O sujeito entrevistado $F$ tem trajetória de formação muito parecida com os docentes $\mathrm{D}$ e $\mathrm{E}$. No entanto ele deixa mais evidente que foi dar aulas por necessidade financeira, e que acabou aprendendo como fazer isso na própria prática, errando e acertando. Nunca teve interesse de trabalhar com formação de professores e não sabia da existência do curso de Licenciatura no IFSP. Estava satisfeito trabalhando em uma instituição privada onde dava aulas em diversos cursos (nenhum ligado a formação de professores), mas foi levado a prestar concurso no IFSP porque a faculdade privada passou por problemas financeiros.

Fica evidente, principalmente nos sujeitos $A, B, C$, e $D$ que o interesse por questões educacionais faz parte de suas trajetórias de vida. Apesar de distintas trajetórias, todos os sujeitos conjugam uma formação 
inicial de física e o interesse por discutir e refletir sobre questões pedagógicas. Assim pudemos crer que os interesses pessoais desses sujeitos dão abertura e algum mínimo subsídio para que eles realizem discussões pedagógicas de forma interessada e comprometida, colaborando para que ocorra a articulação entre conhecimento específico e pedagógico. Podemos então atribuir uma parcela do sucesso na mudança ocorrida, ao fato de que, apesar da mudança se iniciar de forma externa (pela resignificação das diretrizes por um grupo de professores anteriores a eles) ela entrou em ressonância com as missões pessoais (Goodson 2008, pg. 108) desses protagonistas.

Há ainda uma questão incipiente, que é o fato de que esses entrevistados constituem apenas um pequeno grupo, e suas características não podem ser estendidas todos os outros professores.

Dentre os próprios entrevistados temos exemplos disso. $\mathrm{O}$ sujeito $E$, parece ter construído sua experiência de reflexão educacional dentro do próprio IFSP e o sujeito $F$, quase não apresenta reflexões dessa natureza.

Como então podemos entender esse caso, como um caso de mudança bem sucedida em termos das negociações e da criação de uma aceitação coletiva?

Das entrevistas, podemos focar algumas falas, que constituem elementos dessa dinâmica de como uma aceitação coletiva pode ser vislumbrada mediante um processo de negociação, visto que algumas pessoas poderiam ser refratárias a esse modelo inovador de curso.

\footnotetext{
...Porque lógico, romper com essa dicotomia eu acho que é importante, mas eu acho que tem muitos perigos envolvidos aí (...)Então eu acho que tem muitos níveis aí entre a adesão e ser refratário, tem uma questão de uma crítica aí que é importante. (A)

...porque acho que tem maneiras de conduzir também. A gente vende bem o peixe? (risos) Não sei, às vezes você vende bem a ideia não é?! Por que, por exemplo, alguns professores lá, das áreas mais duras falam: ah! A gente não sabe trabalhar isso, então eles pedem ajuda, a gente fala na reunião... (B)

Então, a primeira coisa que eu acho importante perceber é isso, que aqui existe, toda uma... um acolhimento desses professores que não são da nossa área de ensino de física por um grupo todo que é dessa área.(..) Então isso eu acho que já favorece muito! Você ter esse núcleo duro de profissionais que vão acolher aí os que vieram de uma área que não especificamente a de ensino. (C)

E o CEFET eu entrei porque eu tinha acabado o doutorado, e comecei a fazer um monte de concursos. E acabei entrando aqui...
} 
como eu não consegui em nenhum outro eu acabei entrando aqui. (...)Eu acho que foi uma surpresa boa... eu acho interessante dar aula aqui. Quer dizer, você dá aulas pra diversos níveis diferentes, ensino médio, engenharia, formação de professores né? Temos vários cursos de licenciatura. E particularmente nesse curso eu sempre tive um sentimento muito legal com ele, sempre, sempre me interessou. (D)

Então eu, quando entrei aqui, que não tinha nenhuma dessas perspectivas, na verdade eu estava vindo da astrofísica, não tinha nada com o ensino nessa época, enfim... nada muito sério! $E$ enfim, assim que eu conheci, que eu tomei contato com a idéia, eu percebi, nossa, mas é uma idéia ótima! E aí eu vi acontecendo e então me deu vontade de continuar aqui, de trabalhar nessa perspectiva, e agora eu tento exportar essa perspectiva para os outros lugares. Mas uma coisa que eu acho que a estrutura favoreceu um pouquinho a gente, é que, quer dizer, já que a gente só vai ter esse curso de licenciatura, e o pessoal, o grupo é dominado pelo pessoal que está comprometido com a licenciatura, e que tem pós graduação em ensino e esse tipo de coisa (E)

Pudemos perceber em vários trechos da fala do entrevistado $A$ que as atividades de experimentação em física, mais articuladas com a formação de professores que ele pratica hoje com seus alunos, aprendeu no próprio IFSP. Sua formação inicial não contemplava, por exemplo, um laboratório mais voltado à fenomenologia. Os entrevistados $D$ e também demonstram experiências semelhantes, no sentido da descoberta de novas possibilidades ao entrar em contato com essa perspectiva. Assim fica clara a relação de acolhimento ao qual o entrevistado $C$ se refere. Os entrevistados $B$ e $C$, por terem uma pós-graduação mais ligada à área da formação de professores, manifestam a prática de envolver os colegas que chegam nessa perspectiva. E esse processo parece se mostrar bem sucedido.

É interessante ainda notar que o professor $F$, que na época em que a entrevista foi feita, poderia ser considerado mais alheio à proposta e sua inovação, estava na instituição há apenas seis meses. Podemos destacar a fala:

Então quando você fala em mudança aqui, sempre fico com um pé atrás. (...) Agora se essa mudança, se essa nova versão também é pra melhor, acho que teria que investiga o que é que está acontecendo, nesse novo modelo como é que as pessoas estão sendo formadas, que tipo de pessoa que é, colocar todas as variáveis na análise, e ver realmente se essa mudança é uma mudança pra melhor. Eu não sei te dizer. Eu ainda não sei te dizer se essa mudança é pra melhor ou não. Em princípio eu não vejo muito motivo pra, esse modelo, se pior que o anterior, na formação de professores. Pior eu acho difícil que seja. Se é melhor eu não tenho dados ou condições de avaliar. Eu estou há muito pouco tempo nesse mundo, nesse tipo de curso. (F) 
A trajetória formativa do docente $F$ tem várias semelhanças com a dos docentes $D$ e $E$, visto que são advindos da área de pesquisa em física e de uma formação extremamente fragmentada. É interessante notar que uma das características que os diferenciam bastante é o tempo em que estão em contato com a proposta do IFSP. Isso foi destacado inclusive pelo próprio docente $E$, quanto convidado a dar sua opinião sobre as possíveis causas de rejeição de uma proposta diferenciada como a do IFSP.

\begin{abstract}
Agora isso é uma coisa que pode mudar. Por exemplo, agora entrou várias pessoas novas, e tem um núcleo de pessoas novas que não tinham contato com essa proposta. Alguns até tinham, mas outros não. Então uma parte desse pessoal, que até inclusive tem muita gente da física teórica, aí o pessoal de física de partículas, esse pessoal aí até agora, das conversas que eu tive eles estão ainda se identificando com a proposta. Ainda não tiveram muito tempo pra pensar, na coisa e tal. Ainda não sabem exatamente o que é a proposta, mas eu acho que eles estão a ponto de aceitar e fazer as coisas direito.(...) Talvez valesse a pena até você conversar com ele não é?! Pra tentar ver justamente essa transição de uma pessoa que está chegando, conhecendo a proposta e eventualmente, se identificando ou não com ela.
\end{abstract}

Essa fala exemplifica o processo de negociação que existe com os docentes que chegam para trabalhar no IFSP. Esse processo, principalmente no que diz respeito aos docentes com mais tempo de casa, parece estar sendo positivo.

\title{
7.4 Considerações sobre o caso do IFSP
}

É possível concluir que houve por parte dos docentes do IFSP uma resignificação das "Diretrizes Curriculares para Formação de Professores da Educação Básica".

Como já discutido no capítulo três, entendemos que a legislação é um produto híbrido, resultado da negociação de significados e interesses de distintos agentes sociais. Assim, a resignificação produzida no âmbito da prática, no caso analisado, aponta para uma ressonância de certos aspectos das Diretrizes com as expectativas e crenças do grupo criador do curso de Licenciatura do IFSP, no qual não pudemos nos aprofundar, mas podemos destacar o fato de que se tratava de um grupo de professores originalmente do Ensino Médio.

O segmento institucional se mostrou parte indispensável do processo, pois permitiu a instauração do curso nesse formato inovador e tem 
características que o favorecem, mesmo que não o valorize de forma explícita.

Conseguimos identificar nas falas dos docentes alguns elementos que nos dão importantes indícios do que ocorre na dimensão prática do fazer curricular.

Não nos parece que a integração curricular pretendida no projeto tenha ficado apenas no nível da prescrição, como se poderia presumir. $E$ isso porque a maneira pela qual uma grande parte do grupo enxerga o que é "ser professor" e os processos de formação aí imbricados apresenta uma notável coerência com o discurso do Projeto Político Pedagógico do Curso.

$O$ retrato que conseguimos desenhar sobre os saberes e práticas desses professores aponta para uma compreensão articulada sobre os saberes presentes na formação. E essa articulação parece se dar justamente quando se leva em consideração a finalidade formativa de um curso de licenciatura.

A análise dos dados nos leva a concluir que é justamente no reconhecer a finalidade de um curso de licenciatura que se reconhece a necessidade de articulação e as possibilidades de novas configurações para os saberes específicos. A articulação e a desnaturalização dos saberes nos parece muito mais associada a uma consciência dos docentes sobre as finalidades de um curso de formação de professores, do que a uma mera reverberação de discursos oficiais.

Quanto às formas dessa articulação observamos recortes que parecem fortemente influenciados pela perspectiva da racionalidade técnica e alguns outros que a transcendem, representando estados híbridos entre a técnica e a compreensão crítica.

A compressão crítica referente aos saberes envolvidos na formação também se faz presente em trechos de falas de alguns dos nossos entrevistados. Isso nos dá elementos interessantes quanto a articular a linguagem crítica a uma linguagem de possibilidades.

Esse cenário nos leva então a algumas conclusões sobre a viabilidade concreta de se trabalhar saberes de forma articulada e desnaturalizada nos cursos de formação de professores. A análise que fizemos "em caso" demonstra que existem possibilidades práticas de implementação de propostas curriculares estruturalmente diferentes. O âmbito 
das legislações nacionais permite novos formatos como já argumentamos. Verificamos também que na ausência de impeditivos institucionais, formatos inovadores conseguem se instaurar. Embora só instauração do projeto inovador não possa garantir seu pleno sucesso, ela se constitui em um passo fundamental.

No caso por nós analisado, podemos perceber que a continuidade da inovação se deu num processo de institucionalização das crenças e perspectivas do grupo que criou o projeto. Isso porque o grupo que criou o curso em seu formato inovador, não está mais presente, mas o formato se instaurou e teve continuidade.

Claramente podemos perceber que esse novo grupo tem afinidade com a inovação promovida. A contratação de pessoas com esse perfil pode ter sido uma maneira de institucionalizar esse curso em seu formato diferenciado.

A aceitação coletiva da proposta se dá então por meio de um núcleo reduzido de docentes, que se engaja buscando envolver outros colegas, com histórias profissionais diferenciadas e sem familiaridade com as perspectivas integradas.

Assim concluímos que a institucionalização de crenças e perspectivas por meio da instauração de um grupo com histórias e objetivos alinhados com a proposta inovadora permitiu uma diretriz externa induzir uma incorporação criativa, ativa e propositiva.

E é propositiva inclusive no que diz respeito ao conhecimento físico e sua presença no currículo e nas práticas dos professores formadores. Isso porque encontramos o conhecimento físico problematizado, mesmo que não em todos os espaços, e isso indica a existência de algum grau de desnaturalização. Ao se levar em consideração a finalidade desses saberes na formação do professor, vemos apontadas possibilidades e perspectivas de estruturação de um curso de forma diferenciada do modelo $3+1$ e que parece incorporar no currículo de forma mais ampla a preocupação com a formação de professores.

Esse estudo traz elementos, portanto, sobre a viabilidade da realização, na prática, de um curso de licenciatura em física com um formato diferente do modelo " $3+1$ ". A proposta e as práticas em voga são 
diferenciadas. A física é trabalhada em articulação com saberes educacionais em muitos momentos e não se pode dizer que se trata de uma parte independente e estanque do currículo. O mesmo se pode dizer dos saberes pedagógicos, que existem nem sempre na sua forma tradicional, mas permeiam os vários espaços curriculares buscando articulações.

Segundo nossa análise isso se deve, em grande parte, à ausência de uma instância institucional específica responsável pelos saberes educacionais. Muitos dos docentes, enquanto agentes formadores, assumem responsabilidades pedagógicas quanto à atuação do futuro professor, apesar de veicularem também saberes da física.

Embora a ausência do departamento ou Faculdade de Educação traga perigos, pois as discussões educacionais podem perder em credibilidade, profundidade e especificidade, há também vantagens. E a nosso ver a principal vantagem é a articulação que acaba acontecendo de forma intrínseca.

Mas nosso estudo revela também que mesmo o conjunto de todas as condições institucionais favoráveis não seria suficiente. O que transparece da análise dos dados é que todo o processo foi feito com muito engajamento de grande parte dos docentes. E aí estão imbricadas vontades políticas e uma concepção de educação e de ciência que corrobora o projeto formativo.

Do ponto de vista do trabalho como um todo pudemos perceber de forma concreta, a partir das falas dos sujeitos, vários elementos que foram tratados até aqui de forma teórica. É o caso da finalidade educacional, da concepção de professores e das relações entre os saberes.

Esse caso concreto também nos ajuda a ver de forma mais nítida o que seria pensar o saber de física em uma perspectiva crítica. Embora seja um tanto claro que ao assumir uma perspectiva crítica, tanto do ponto de vista do currículo, quanto da formação de professores, não possamos apostar em receitas prontas, parece-nos que essa análise em caso cria alicerces concretos sobre os quais podemos estruturar nossa tese sobre os saberes de física na formação docente. 


\section{CAPÍTULO 8}

\section{A Física e a Licenciatura}

Tenho o privilégio de não saber quase tudo

E isso explica o resto

Manoel de Barros

No percurso que fizemos, nos capítulos anteriores, tentamos evidenciar a problemática dos saberes de física que compõem o currículo dos cursos de licenciatura. Nossa análise mostra que essa questão tem recebido pouca atenção, o que indica que, em quase todas as esferas por nós pesquisadas, os saberes de física parecem estar profundamente naturalizados.

Argumentamos que mudanças estão sendo propostas e implementadas no ensino básico e que as "Novas Diretrizes para Formação de Professores da Educação Básica", dentre outros entendimentos possíveis, abre espaço para aportes mais inovadores em relação aos saberes específicos. Essa possibilidade ficou explicitada, de forma mais concreta, a partir do caso estudado, o IFSP. Por outro lado, tanto no âmbito da pesquisa em ensino de ciências, quanto no âmbito dos trabalhos sobre os cursos de licenciatura, os questionamentos e problematizações parecem não atingir a parte do currículo sobre a qual repousam os saberes específicos.

A concepção muito difundida de que um professor de física "deve saber física", ou mesmo, que deve "saber bem física", ou que deve "saber muita física", pode esconder uma visão pouco crítica a respeito do currículo e do conhecimento. A partir de nossas reflexões, nossa preocupação é, então, em relação às perguntas do tipo: "O que é a física? Qual é a física que o professor deve saber? e Por quê deve aprender determinada física?"

Nesse capítulo iniciaremos fazendo uma discussão sobre a intersecção que exploramos ao longo do trabalho, das áreas da formação de 
professores e das questões curriculares.

Em seguida nos debruçaremos sobre a questão das finalidades de um curso de licenciatura, primeiramente lançando um olhar crítico sobre suas formas consolidadas ao longo do tempo, e depois trazendo alguns recortes cronológicos para situar a formação de professores em um contexto mais amplo, de forma a vislumbrar articulações.

Por fim chegaremos ao cerne da nossa tese, tratando do problema dos saberes de física na formação docente, e defendendo uma formação inicial que propicie a formação de um docente autônomo e crítico, inclusive em relação ao conhecimento físico.

\subsection{Saberes sobre Formação de Professores e Saberes sobre Currículo}

Em primeiro lugar, podemos argumentar sobre a falta de intersecção entre os resultados de reflexões das áreas de conhecimento de Currículo e de Formação de professores. A vasta literatura existente sobre formação docente não incorpora, muitas vezes, os saberes produzidos no âmbito das questões curriculares.

Embora os grandes movimentos ligados à educação, como a incorporação da perspectiva crítica, tenham deixado profundos reflexos em ambas as áreas, os usos que a formação de professores e que as reflexões curriculares fazem dessa tendência, nos parecem profundamente independentes.

Apesar, inclusive, de existirem marcas de autores em comum, como os muito citados Giroux e Freire, por exemplo, as abordagens que deles se fazem são distintas.

A área de formação de professores e suas tendências e autores mais citados, cujo breve estudo fizemos no capítulo dois, incorpora a tendência crítica do ponto de vista dos saberes educacionais. Estão ausentes abordagens que olhem com desconfiança para os currículos de formação de professores do ponto de vista de uma perspectiva mais ampla, que leve em conta os saberes específicos.

Por outro lado, os saberes produzidos na área de currículo estão em esmagadora maioria voltados à educação básica. Da tendência crítica de currículo emerge todo um questionamento sobre possíveis 
conteúdos a serem designados para o ensino em nível básico. O status do que é validado para ser ensinado entra em cena e os saberes considerados academicamente respeitáveis são postos à prova.

Por que então essa discussão não chega aos saberes acadêmicos específicos das ciências naturais, que são parte integrante dos currículos das licenciaturas? Por que, quando se defende a formação do professor crítico, reflexivo, pesquisador, só se questiona a parte do currículo que abriga os saberes pedagógicos? Por que, para a formação desse professor crítico, só estão no foco, em geral, as pesquisas e as práticas de ensino, as metodologias e os estágios?

Defendemos que incorporar a perspectiva crítica de currículo à área de formação de professores pode ser um avanço em direção à formação do professor crítico e autônomo. Defendemos que os currículos de formação de professores devem ser estudados e pesquisados em sua totalidade, e que todos os saberes devem ser alvo do olhar crítico. Defendemos que saberes profundamente naturalizados nesses currículos, como parecem estar os saberes de física, devem ser também problematizados.

\subsection{A Física no Currículo da Licenciatura: suas finalidades}

Temos mencionado ao longo de todo o trabalho a questão da finalidade de um curso de licenciatura como algo central. Como também já explicitamos, em função dessas finalidades, acreditamos que deva haver alguma correlação da licenciatura em Física com o que se espera do ensino de física na educação básica.

No entanto, a busca da compreensão histórica que consolidou alguns pressupostos da formação docente nos revela uma arraigada concepção, mesmo que nem sempre explícita, de que o professor se forma pela soma ou justaposição do conhecimento do conteúdo, que é objeto de ensino, e da formação pedagógica.

A esse quadro, acrescentamos algumas características específicas da física, que dizem respeito a essa ser uma área de conhecimento extremamente paradigmática, da qual a imagem construída e ainda predominante hoje, (e apesar de todos os esforços dos estudos sociológicos e filosóficos), é de uma área de conhecimento que reflete a 
expressão de verdades universais.

Uma formação inicial que persiste na ideia de que parte do currículo deve se dedicar a uma formação em física de forma desvinculada da finalidade da licenciatura, quando somada a uma visão de ciência positivista e ingênua, pode resultar em uma profunda naturalização dos saberes de física e das disciplinas associadas a esses saberes. É como se as sequências clássicas, a divisão e a articulação de disciplinas, como a mecânica, o eletromagnetismo e a termodinâmica, fossem expressões diretas do verdadeiro conhecimento sobre a natureza.

Nesse trabalho, nos apropriamos do entendimento crítico sobre o currículo e, portanto, assumimos que não é apenas a lógica do conhecimento científico que estabeleceu e consolidou as formas das disciplinas de física tradicionais nos currículos dos cursos de licenciatura.

Para além da existência de uma correspondência epistemológica entre essas disciplinas e as grandes áreas que se estabeleceram na física ao longo da história, delimitando formas próprias de se construir e de se instrumentar, existem fatores outros que influem na organização e seleção de conteúdo. E é o resultado de tudo isso que culmina no formato de disciplinas sedimentadas como eletromagnetismo, mecânica e termodinâmica.

E isso porque há de se reconhecer, assumindo a perspectiva crítica, que a divisão do conhecimento, a seqüência que lhe é atribuída, as eleições e omissões, as ênfases adotadas e o nível de detalhamento, são construções complexas, e delimitadas por escolhas. Muitas vezes os valores que balizam essas escolhas existem apenas de forma tácita. Fatores como a operacionalidade, a facilidade de traduzir em exercícios e de avaliar de forma objetiva um dado conteúdo, dentre outros, podem ter forte influência sobre o processo de consolidação de uma disciplina.

Se lançarmos sobre as tradicionais disciplinas de física um olhar curricular crítico, podemos certamente imaginar condições históricas e sociais que estabeleceram os formatos tão naturalizados que conhecemos. Nesse sentido, compreendemos que as sequências tradicionais veiculadas pelas disciplinas de mecânica, eletromagnetismo e termodinâmica, não são expressões da verdade da natureza, mas sim, disciplinas "escolares", que 
foram se estabelecendo e se construindo por processos históricos e sociais a fim de responder a finalidades formativas.

Para compreender quais foram os processos históricos que assim consolidaram essas disciplinas, seria necessário realizar uma pesquisa nos moldes das pesquisas sobre a "história das disciplinas escolares", como proposto por Goodson (1990), por exemplo. Uma abordagem como essa, no entanto, foge ao escopo desse trabalho.

Em nosso objetivo de problematizar os saberes da física nos currículos de licenciatura, nos limitaremos a inferir algumas considerações sobre as finalidades dessas disciplinas como parte integrante de um currículo de licenciatura. Nesse sentido, buscamos explicitar alguns possíveis vínculos com as finalidades da escola básica. Para tanto, tomamos por base as reflexões sobre os estudos históricos, sobre a escola básica e sobre os modelos de formação docente no Brasil, que apresentamos no capítulo três, quatro e cinco, e em argumentos sobre a natureza do conhecimento físico, que apresentamos no capítulo um.

Embora os estudos sobre a história das disciplinas, em geral, se reportem a disciplinas estritamente escolares, ou seja, da escola básica, assumimos que alguns elementos podem ser extrapolados para as disciplinas de física que integram os cursos de formação de professores.

A desnaturalização de conteúdos e disciplinas ocorre quando assumimos a existência de fatores que vão além de critérios epistemológicos. Assumimos, portanto, que as sequências e formas veiculadas pelas disciplinas não são expressões do conhecimento em si, mas refletem escolhas.

Esses mesmos aspectos podem ser estendidos, também, para a forma pela qual se estabeleceram as disciplinas de física dos currículos das licenciaturas. Haja vista que não seria tarefa simples encontrar uma correspondência das disciplinas dos cursos básicos de física do Ensino Superior com as áreas atuais de pesquisa em física. Nem seria trivial, também, associar essas disciplinas com a forma histórica pela qual esses conhecimentos se estabeleceram ao longo do desenvolvimento da ciência.

Defendemos que essa visão desnaturalizada das disciplinas e dos conteúdos, aliada a uma compreensão não ingênua da natureza da ciência, permitiria que os atores envolvidos nos cursos de licenciatura 
percebessem que a maneira consolidada e tradicional, cristalizada pelos currículos e pelos livros e manuais didáticos, não é a única forma de organizar o conhecimento físico. Nem a única, nem necessariamente a mais apropriada.

Argumentamos, ainda, que essa forma tradicional e consolidada não corresponde aos objetivos formativos da licenciatura, se assumirmos uma postura crítica em relação à formação de professores. Como tentamos explicitar no capítulo três, os cursos de formação de professores para o secundário (atuais licenciaturas), surgiram a partir da soma de uma formação pedagógica a um aprendizado dos saberes específicos que já era oferecido nos cursos de bacharelado.

Ainda que isso representasse um avanço na década de 1930, pelo reconhecimento de que é preciso ter também saberes pedagógicos para exercer o ensino, não podemos aceitar que depois de quase um século de transformações na educação básica e na sociedade, esse modelo continue adequado.

Os cursos de bacharelado têm o objetivo de formar um profissional com conhecimento erudito e aprofundado sobre determinado assunto, e prepará-lo para a posterior pesquisa e aprofundamento do conhecimento do campo.

As finalidades de um curso de licenciatura são muito diferentes. Principalmente, se reconhecermos propósitos específicos na educação básica, que não necessariamente visa a formação de futuros físicos, e se temos clareza sobre o papel que deva ser assumido pelo futuro professor.

Como já mencionado, seria preciso um estudo específico para entender a evolução dos conteúdos e disciplinas nesse contexto. Mas é fato que a consolidação das disciplinas e manuais do ensino e, portanto, a organização e seleção do conhecimento físico nos cursos de licenciatura no formato " $3+1$ ", levou em conta objetivos formativos e especificidades que não se alinham com a perspectiva atual de formação de professores para a educação básica.

Argumentamos que é necessário mudar, e tomamos o caso do IFSP como um exemplo privilegiado de uma das possíveis formas de incorporar um olhar diferente sobre os saberes de física dentro do currículo de um curso de licenciatura. 
$\mathrm{Na}$ sequência, vamos procurar, justamente, sistematizar algumas características dos processos de mudança ocorridos na educação básica, nas últimas décadas, e as suas relações com mudanças nos cursos de formação de professores. Para tanto, faremos uma abordagem na forma de processo, na qual tentamos vislumbrar tendências.

\subsection{Saber científico, Formação de Professores, Ensino de Ciências e a Escola Básica}

Ainda para argumentar que é preciso desnaturalizar os saberes de física e repensá-los segundo uma nova finalidade formativa, apresentamos a seguir uma reflexão na qual buscaremos destacar algumas mudanças emblemáticas que ocorreram nas últimas décadas.

Isso significa reconhecer que a formação do professor não se dá em um contexto isolado, mas sim em um espaço sob o qual incidem também políticas e ações em diferentes âmbitos. Nesse sentido tentaremos pensar a formação de professores em um contexto mais amplo.

Nos capítulos três e quatro apresentamos aspectos de uma perspectiva histórica, visando ter uma breve compreensão dos modelos vigentes na escola básica, no ensino de ciências e na formação de professores no Brasil.

Nesse sentido, construiremos aqui uma abordagem que se baseia justamente numa visão de mudança em processo, mapeando a cronologia de algumas tendências.

Salem (2012) no intuito de fazer um panorama da área de Ensino de Ciências traz uma perspectiva descritiva de alguns acontecimentos considerados marcos nos últimos quarenta anos. Nesse sentido se utiliza do panorama construído por Kawamura (2011), sobre perspectivas da educação científica no Brasil, inseridas no contexto de eventos e políticas educacionais.

Usaremos então alguns elementos e recortes cronológicos de acontecimentos demarcados por Kawamura (2011) e Salem (2012), incorporando inclusive os mesmos períodos de tempo delimitados nesses trabalhos.

Os quatro períodos demarcados por essas autoras são: o período que vai do início da década de 70 a meados da década de 80 , o que 
vai de meados da década de 80 a meados da década de 90 , o que vai de meados da década de 90 a meados dos anos 2000 e o período de meados dos anos 2000 até o presente (2005-2011).

Construindo uma análise que se utiliza dos recortes cronológicos trazidos por essas duas referências, procuramos ainda incorporar a questão da formação do professor. Assim montamos um panorama que visou relacionar: as políticas educacionais vigentes, a pesquisa em ensino de ciências, as ações no âmbito do ensino de ciências, o papel do professor e o papel do conhecimento físico.

Essa abordagem pretende chamar atenção para as articulações possíveis e evidenciar o caráter processual presente no período em questão. A essência da análise se encontra na tabela 8.1.

Como exemplo emblemático das articulações que estamos tentando evidenciar, podemos citar a mudança na concepção de professor e sua relação com a física ensinada na educação básica.

No período que marca a década de 1970 temos uma concepção na qual o professor, em consonância com a racionalidade técnica, tem como função predominante a aplicação de técnicas o uso dos materiais didáticos produzidos pelos especialistas de acordo com o conhecimento científico. A física a ser ensinada era a física para formar futuros cientistas, na qual a experimentação tinha um papel central. Nessa década acontece o I SNEF (Simpósio Nacional de Ensino de Física).

Já a década de 1980 é marcada pelo reconhecimento do professor como indispensável ao processo, mas ainda não como elemento central. O ensino de física passa pelo paradigma das "concepções prévias", no qual a mediação do professor diante do conhecimento das concepções espontâneas dos alunos é fundamental à aprendizagem. Nesse contexto surge a "Revista Brasileira de Ensino de Física".

Nos anos de 1990 a física a ser ensinada ganha mais vínculos com a realidade cotidiana dos alunos, enquanto o professor assume um papel central no processo de ensino, com exaltação da importância das didáticas específicas. Nesse período começam a ser levadas em conta algumas especificidades na formação docente.

Os anos 2000 foram marcados pela figura central de um 
professor que além de ser parte ativa e central do processo educativo deve realizar seu fazer de forma autônoma. $O$ ensino de física se volta à formação para cidadania balizado pela noção de competência e não mais pelos conteúdos.

O que estamos procurando sinalizar é que a formação do professor tem relações com as mudanças em outros âmbitos. $E$ a consciência da necessidade de mudanças na formação, visando acompanhar outras mudanças, parece ser algo muito tácito a maior parte do tempo.

Procuramos destacar com essa reflexão, que diante de um processo no qual mudaram constantemente de significado, a escola básica, o papel do professor, os paradigmas da pesquisa do ensino de ciências e as visões sobre a física a ser ensinada na escola, é preciso mudar também a física ensinada na licenciatura.

Se pretendemos formar um novo professor, que irá atuar e construir um novo ensino médio e trabalhar pela formação do cidadão crítico, não é possível apostar que a mesma forma curricular da física definida há muitas décadas para formação do bacharel possa ser a melhor opção.

Assim defendemos que nos currículos de formação de professores é necessário assumir responsabilidades quanto aos objetivos de formação. E se reconhecemos novas finalidades e interesses educacionais, no próprio ensino médio como rezam os PCNs, conteúdos clássicos como mecânica, termodinâmica ou eletromagnetismo, não podem ser vistos pelo seu valor intrínseco, e trabalhados como disciplinas autônomas e isoladas nos cursos. É preciso problematizar os objetivos formativos, tendo em mente que tanto método quanto conteúdo, devem responder a esses objetivos.

É preciso deixar claro que não trataremos aqui apenas de propostas de modificar os conteúdos curriculares ensinados ou seus métodos e instrumentos. $O$ que propomos nesse ensaio trata-se de pensar a formação do professor de física, de forma alinhada com a perspectiva crítica, de modo que ele detenha autonomia, inclusive sobre os saberes de conteúdo, e que isso lhe permita atender às perspectivas de transformação social com as quais esteja comprometido.

Se nossa finalidade formativa for a formação de um professor crítico, reflexivo, e comprometido com valores e com a transformação da 
realidade na qual atua, é preciso que ele detenha autonomia, no sentido aqui discutido, para construir, inclusive com os saberes da física, um projeto educativo responsável e consciente. 


\section{Políticas educacionais vigentes}

Criação do Segundo Grau

(ou seja, científico para todos)

Ensino Profissionalizante

Reforma Universitária.

Proposta as licenciaturas curtas

Programas de Pós Graduação

Ciência nos planos de desenvolvimento
Expansão da escola média e das demais ofertas de ensino (EJA)

Ação do Estado no âmbito de projetos

de avaliação e controle (modelo neoliberal).

Expansão do ensino superior privado
Ensino Médio (como educação básica) não propedêutico

Legislações e ações regulardoras:

LDB, PCNs, Projetos PPE, Diretrizes para a Formação de Professores

Ruptura explícita da Licenciatura e do bacharelado

\section{Projetos de Ensino (PSSC) no Brasi} (1965)

Centros de Ciências, IBECC (em SP) I SNEF

\section{Ações no âmbito do Ensino de Ciências}

Projetos de Ensino Nacionais (PEF, FAI, Projetos SPECT/CAPES/PADCT: apoio etc.). Criação da RBEF à formação continuada em todo o país

Criação da Área de Ensino de Ciências na CAPES

\begin{tabular}{|c|c|c|c|}
\hline \multicolumn{4}{|c|}{ Pesquisas em Ensino de Ciências } \\
\hline $\begin{array}{l}\text { Cientistas são os mais indicados para } \\
\text { propor o quê ensinar }\end{array}$ & $\begin{array}{l}\text { Teorias de aprendizagem da psicologia } \\
\text { cognitivista: Piaget e o construtivismo. } \\
\text { Concepções espontâneas, mudança } \\
\text { conceitual. }\end{array}$ & $\begin{array}{l}\text { Teorias Interacionistas (Ausubel e } \\
\text { Vigostky) } \\
\text { Formação de professores como objeto } \\
\text { de investigação } \\
\text { Didática específica. }\end{array}$ & $\begin{array}{l}\text { Diversificação de olhares e } \\
\text { perspectivas. Abordagens sócio- } \\
\text { culturais. Tecnologia da informação. } \\
\text { Linguagem e cognição. } \\
\text { Como se aprende a ser professor. }\end{array}$ \\
\hline \multicolumn{4}{|c|}{ O papel do professor } \\
\hline $\begin{array}{l}\text { Acessório } \\
\text { Ensino à prova de professores. } \\
\text { Intermediários entre propostas e alunos. }\end{array}$ & $\begin{array}{l}\text { Importante } \\
\text { Passa a ser reconhecido como condutor } \\
\text { indispensável do processo, mas ainda } \\
\text { não é fundamental }\end{array}$ & $\begin{array}{l}\text { Central (didática específica) } \\
\text { Papel central do professor (ainda como } \\
\text { elo de um processo) e as } \\
\text { especificidades de sua formação. }\end{array}$ & $\begin{array}{l}\text { Central e autônomo } \\
\text { Professor como parte ativa do processo, } \\
\text { seu espaço de produção próprio e } \\
\text { necessária autonomia }\end{array}$ \\
\hline \multicolumn{4}{|c|}{ Que Física ensinar? } \\
\hline $\begin{array}{l}\text { A física para formar futuros cientistas. } \\
\text { Papel central da experimentação. }\end{array}$ & $\begin{array}{l}\text { A física com ênfase conceitual. Do } \\
\text { senso comum ao conhecimento } \\
\text { científico. Percepção da construção } \\
\text { histórica da Física. }\end{array}$ & $\begin{array}{l}\text { A física com vínculos mais próximos } \\
\text { com a realidade cotidiana. Física no } \\
\text { cotidiano. Especificidade da Física na } \\
\text { formação de profissionais. }\end{array}$ & $\begin{array}{l}\text { Física para a cidadania. } \\
\text { Competências em Física. }\end{array}$ \\
\hline
\end{tabular}

Tabela 8. 1 - Mudança em processo 


\subsection{Saberes, Física e Autonomia Docente}

A partir do quadro de mudanças desenhado na seção anterior podemos descortinar mais alguns elementos da tese que pretendemos sustentar. Viemos argumentando sobre a importância de se considerar a finalidade de um curso de licenciatura com vistas ao que se espera do futuro professor alinhado a um projeto educativo. E ao se falar da formação de professores na atualidade, pretendemos incorporar as tendências sinalizadas pela área da formação de professores e algumas expectativas que recaem sobre a educação básica no presente, sempre do ponto de vista da perspectiva crítica.

Nesse sentido trazemos ao cenário a figura de um professor que deve ser o protagonista da sua própria prática e deve ser capaz de fazer escolhas em função das finalidades de sua atividade docente. Esse professor deve ter consciência das finalidades educativas com as quais está comprometido e deve dispor de um arsenal, tanto de conhecimentos, quanto de estratégias que lhe permita fazer escolhas adequadas, inclusive do ponto de vista da física.

Assim argumentamos que esse professor deve deter autonomia. Porém, como nos adverte Contreras (2002), é preciso ter cuidados frente a esse conceito "pois o significado que ela (a autonomia) possa adquirir depende da forma com que tenham se solucionado as relações entre práticas, finalidades, exigências e condições de contexto" (CONTRERAS, 2002, p. 191).

$E$ os diferentes significados que podem ser adquiridos pela autonomia docente se situam, para Contreras, nos marcos sobre a formação de professores também presentes no capítulo dois. Tratam-se das concepções: da racionalidade técnica, da racionalidade prática e da visão do professor como intelectual crítico.

Contreras (2002) aborda, com clareza, a perda de autonomia que reflete o controle técnico e ideológico do ensino que reduz os professores a meros executores de decisões externas (concepção técnico racionalista), e seus reflexos negativos no ensino.

Já a perspectiva do docente reflexivo, ou seja, da racionalidade prática, conduz à noção de autonomia como forma de 
intervenção em contextos concretos da prática, na qual as decisões são resultado de considerações da complexidade, ambigüidade e conflituosidade das situações (CONTRERAS, 2002).

Como construção reflexiva, a autonomia só pode se dar em um contexto de relação, e, portanto, numa concepção de atuação profissional baseada na colaboração e entendimento e não na imposição. Não pode ser definida pela capacidade isolamento nem pela capacidade de evitar influências. Deve ser encarada como uma tarefa moral, da qual se é publicamente responsável (ibidem).

O modelo do professor como intelectual crítico vai além e argumenta que a autonomia está associada a um questionamento que ultrapassa as:

dependências ideológicas que impedem a tomada de consciência da função real do ensino, das limitações pelas quais nossa prática se vê submetida e da forma pela qual estas dependências são assimiladas como naturais e neutras (CONTRERAS, 2002, p. 203).

Segundo Potenza (2011), o exercício da autonomia se associa justamente ao questionamento sobre as funções do ensino, ou seja, a tomada de consciência sobre as finalidades educativas. Nas palavras dessa autora:

A desnaturalização e desneutralização daquilo que é ensinado, através da explicitação coletiva da diversidade de práticas, finalidades e entendimentos, é o que nos mostra o caminho para a Autonomia (POTENZA, 2011, p. 111)

Essa definição de autonomia, que vai além da possibilidade de que o professor escolha suas estratégias e tome decisões derivadas de reflexões em sua prática, exige que o professor faça escolhas em função de finalidades das quais tem consciência.

Assim entendemos que é necessário ao professor que deteria essa autonomia, da perspectiva crítica, que ele tenha possibilidades de fazer escolhas também quanto aos conteúdos que são objetos de ensino. Mas como fazer isso? Como o professor poderá pensar os saberes que são objetos de ensino para que eles respondam às finalidades assumidas em relação ao ensino? O que fazer com os conteúdos que são objetos de ensino?

Para tentar responder a essas perguntas e buscar indicativos de como os professores podem trabalhar com os conteúdos que são objetos de ensino, numa perspectiva crítica, adentramos à obra de Paulo Freire. 
Freire também traz elementos em defesa de uma concepção de autonomia que vemos alinhada à perspectiva crítica:

\begin{abstract}
Um esforço sempre presente à prática da autoridade coerentemente democrática é o que a (a autonomia) torna quase escrava de um sonho fundamental: o de persuadir ou convencer a liberdade de que vá construindo consigo mesma, em si mesma, com materiais que, embora vindos de fora de si, sejam reelaborados por ela, a sua autonomia. É com ela, a autonomia, penosamente construindo-se, que a liberdade vai preenchendo o "espaço" antes "habitado" por sua dependência". Sua autonomia se funda na responsabilidade que vai sendo assumida. (Freire, 1996, p. 105 grifos do autor)
\end{abstract}

Entendemos, assim como Freire e Contreras, que a autonomia de professores, de uma perspectiva crítica, se funda exatamente em assumir responsabilidades, que em nossa leitura, se tratam de responsabilidades quanto às finalidades formativas. Feito isso há de ter liberdade para construir e elaborar os conteúdos, métodos e caminhos para se exercer o ensino.

E na tarefa de pensar que processos são necessários para que os saberes se mobilizem em função de uma atitude autônoma do professor, citamos mais um trecho de Paulo Freire na obra "Pedagogia da Autonomia":

Ninguém é autônomo primeiro para depois decidir. A autonomia vai se constituindo na experiência de várias, inúmeras decisões, que vão sendo tomadas. (Freire, 1996, p.120)

Centrado no projeto de uma educação problematizadora, Freire (1977) discute o papel dos saberes na relação entre educadores e educandos. Para ele, o homem é por excelência um ser de decisão e não de adaptação.

A praxis nos permite problematizar a ação reflexiva do ser humano em contato com a realidade. Esse conceito pretende reconciliar a teoria e a prática, vistas por ele como entes inseparáveis. Para Freire, toda ação subentende uma teoria, quer a reconheçamos ou não, e a reflexão sobre a ação ressalta a teoria, sem a qual a prática não seria verdadeira (Freire 1977, p. 40).

Isso nos leva ao questionamento de qual o papel do conhecimento científico nesse processo. Freire faz uma discussão sobre os saberes científicos e os saberes "não-científicos", ou saberes das práticas. Embora ele se refira, nessa discussão, aos saberes dos trabalhadores rurais, não achamos que isso invalide extrapolarmos essa visão para uma concepção 
mais geral de educação.

Freire destaca que muitos dos pensamentos não-científicos têm sua própria estrutura lógica. Entretanto, formas ingênuas de captação da realidade, onde o sujeito se sente mais como parte da realidade do que como transformador dela, precisam ser problematizadas, buscando a emancipação do sujeito na construção de uma forma crítica de atuar. Para ele "o conhecimento se constitui nas relações homem-mundo, relações de transformação e se aperfeiçoa na problematização crítica dessas relações". (Freire, 1977, p. 36)

Nesse sentido entendemos que os saberes objetos de ensino, saberes esses que o professor deve mobilizar de uma perspectiva crítica, tratam-se de saberes que possam instrumentar o sujeito a se sentir capaz de transformar a mundo.

E para que esse professor possa mobilizar conhecimentos específicos a serviço de um compromisso social assumido por meio das finalidades que pretende em sua atividade educativa, é preciso que ele detenha autonomia também em relação aos conteúdos.

Isso significa esperar do professor que, a partir de sua autonomia, seja capaz de elaborar seleções próprias do conteúdo a ser ensinado, bem como sua sequenciação e articulação, além de eleger os métodos e estratégias, de modo que tudo isso responda, de forma coerente, às responsabilidades educacionais por ele assumidas.

Nesse sentido podemos nos referir a uma autonomia do professor em relação aos objetos de ensino ou autonomia sobre os conteúdos.

Os próprios PCN são parâmetros curriculares que apontam possíveis caminhos, pois não se constituem um currículo fechado e prescritivo. E esses caminhos passam pela valorização do Projeto Político Pedagógico da escola. Embora não haja nos PCN menções explícitas a objetivos transformadores, entendemos que a valorização do Projeto Político Pedagógico da escola pode ser uma maneira de induzir a escolar a "pensar a que veio", ou seja, a definir e explicitar suas finalidades.

Para além disso, podemos idealizar uma escola na qual o professor tenha que fazer escolhas em termos de um projeto político e ético com o qual esteja comprometido. Defendemos, então, de forma alinhada com 
a perspectiva freireana, que o professor traga a consciência da realidade do aluno e do seu potencial de transformar.

E dessa perspectiva assumimos que os saberes de física têm seu papel a desempenhar. Defendemos a importância de uma atitude eminentemente política do professor assim como o respeito e o entendimento sobre as várias formas de conhecer o mundo. Há de se reconhecer o saber da ciência como uma dessas formas, há de se reconhecer suas peculiaridades e seu poder de generalização, e há de se reconhecer as possibilidades de relação com outras formas de saber.

Perguntamos-nos então: que saberes de física deve ter um professor para que esse saber seja mobilizado numa situação de ensino/aprendizagem que se justifique como forma potencial de transformar uma realidade social específica?

É preciso que o professor vivencie um processo formativo que valorize a construção de sua autonomia. Isso significa, dentre outros aspectos, construir uma visão crítica sobre a própria ciência e uma visão que possa desnaturalizar o conhecimento corporificado no currículo.

A despeito de sua formação política e das visões de mundo, de sociedade e de educação que esse professor venha a construir em sua formação inicial, defendemos que essa mesma formação inicial deve proporcionar uma experiência formativa rica e diversificada em relação aos saberes de física.

Defendemos que é preciso colocar o futuro professor, durante sua formação inicial, diante de formas diferentes de trabalhar o conhecimento científico de acordo com finalidades diversas. É preciso também discutir essas diferentes abordagens e explicitar suas formas de construção frente a essas finalidades. E o futuro professor deve ter consciência desse processo.

Para além dos momentos de ensino/aprendizagem que, reconhecemos, requerem certos mergulhos e aprofundamentos em corpos de conhecimento consolidados, pois existe também uma dimensão epistemológica que é preciso respeitar, há de se trabalhar por uma visão crítica sobre o próprio conhecimento.

Isso significa entender as relações e as possibilidades desse saber. Forma e conteúdo têm de servir de forma consciente e explícita às 
finalidades educativas. É preciso desnaturalizar as sequências tradicionais dos livros, é preciso desestruturar o conhecimento e usar outras configurações, inclusive observando os limites permitidos dentro de tal ou qual corpo de saberes.

Defendemos que o licenciando tenha contato com várias configurações possíveis para um mesmo corpo de conhecimentos, de modo que ele possa construir sua autonomia sobre os conteúdos de física.

Por exemplo, com referência à área de conhecimento denominada em física de Mecânica Clássica, defendemos a existência de várias possibilidades de organização do conteúdo. Seria possível ao licenciando aprender mecânica por meio da sequência tradicional da disciplina mecânica com sua ênfase na cinemática, mas também aprender essa mesma mecânica por meio de uma sequencia histórica levando em conta o desenvolvimento das teorias gravitacionais, ou mesmo ter contato com a sequencia proposta pelo GREF (Grupo de Reelaboração do Ensino de Física), na qual se valorizam as grandezas físicas passíveis de conservação.

Se o licenciando tiver contato com diferentes abordagens, de modo que elas sejam trabalhadas explicitando finalidades distintas, acreditamos que ele possa construir uma visão desnaturalizada do conhecimento. E isso irá the conferir uma autonomia em relação aos conteúdos que são objetos de ensino. Sabendo que os saberes de mecânica, por exemplo, não correspondem unicamente a uma sequencia sólida de conteúdos, mas permitem distintas formas de organização e seleção, esse professor será capaz de rearranjar esses saberes de acordo com suas finalidades específicas. E poderá criar formas próprias de organização e seleção dos saberes da física.

Um professor que detivesse essa autonomia sobre os conteúdos, não estaria preso estritamente a uma sequência didática, ou seja, a um corpo de conhecimentos da única forma como o aprendeu.

Ao ensinar física para uma turma noturna de ensino de jovens e adultos, por exemplo, esse professor com a sua autonomia sobre os saberes de física, seria capaz de elaborar sua própria seleção e organização de conteúdos, bem como, fazer relações com outros saberes que sejam relevantes para aquela realidade em particular. Como afirma Oliveira (2006): 
... antes de listar qualquer conteúdo de Física, por exemplo, é necessário o professor compreender porque é importante que seu aluno adquira aquele conhecimento, ou seja, de que maneira a Física poderá ajudá-lo a interpretar a sua realidade social e, interpretando-a, transformá-la (p.62)

As disciplinas integradoras e a ação das faculdades ou departamentos de educação têm desempenhado um importante papel na formação de professores de física, inclusive sobre a conscientização em relação às finalidades da educação básica. Podemos dizer inclusive que são as reflexões decorrentes das pesquisas e práticas no âmbito da formação de professores e da pesquisa em ensino de ciências que nos permitem chegar ao nível de questionamento aqui apresentado.

Não acreditamos, porém, que os currículos das licenciaturas como um todo possam propiciar a autonomia almejada da perspectiva crítica, se constituídos, em grande parte, por disciplinas de física que passam uma visão estática de conhecimento.

Argumentamos que tratar de maneira isolada e acrítica os conteúdos de física constitui-se num processo que enraíza a visão de que a física é única, determinada, sem conflitos, sem história e sem cultura. Cremos que essa prática fere a possibilidade de uma futura autonomia docente, uma vez que as finalidades educativas e os valores ficam ocultos, e não parecem existir outras possibilidades de configurações da própria física.

É preciso falar de uma física desmistificada, que tem história e cujas formas didáticas foram se construindo. É preciso propor outras formas didáticas, com referência a finalidades de ensino distintas. É preciso discutir a física e o papel que ela pode desempenhar na educação, levando em conta diferentes possibilidades.

Dessa maneira pensamos estar compactuando com a proposta freireana, na qual o conhecer é tarefa de sujeitos e não de objetos. $E$ se o conhecimento exige um sujeito, uma ação curiosa desse sujeito em face ao mundo, e sua ação transformadora sobre a realidade, defendemos que assim seja em relação aos licenciandos e aos conhecimentos de física.

Argumentamos que o conhecimento de física não pode existir em um curso de licenciatura de forma pré-determinada e estanque. É preciso construir o conhecimento com o sujeito. E para que esse sujeito, o licenciando, 
possa de fato chegar a conhecer a física, no sentido freireano, se requer que estejam aí associadas formas de intervenção e transformação da realidade. Essa dimensão transformadora do conhecer, em nosso entendimento, vem da perspectiva da ação do licenciando como futuro docente.

Nesse sentido fica claro, para nós, o quanto a separação entre conteúdos de física e conteúdos pedagógicos no currículo das licenciaturas inviabiliza uma proposta verdadeiramente dialógica de formação.

Defendemos que a presença dos saberes de física nos currículos de formação de professores assuma também responsabilidades formativas, que não se restrinjam a um doutrinamento do conteúdo, mas que problematize o papel desses conhecimentos enquanto parte da cultura.

Acreditamos que essa discussão se faz urgente nas instâncias colegiadas dos cursos de licenciatura. É preciso criar formas mais ricas e uma gama maior de possibilidades de tratar os conteúdos de física, que sejam alternativas e que lancem um olhar crítico sobre as formas tradicionais que aliás, muitas vezes, são consideradas a única possibilidade existente.

Nesse sentido, o caso por nós explorado no capítulo sete, nos mostra que existem possibilidades e nos dá indícios de configurações institucionais e de perfis docentes que podem favorecer práticas inovadoras.

Além disso, a análise das condições que tornaram viável o formato inovador explorado no caso em estudo pode desvelar possíveis caminhos.

É preciso "bagunçar" um pouco a física trabalhada na licenciatura. É preciso rever a imagem de física e de ciência veiculada nos cursos. É preciso que o corpo docente como um todo reconheça a finalidade da licenciatura e assuma responsabilidades formativas. É preciso que se construa essa unidade docente, uma unidade na diversidade.

Para tanto cremos ser necessário um esforço do conjunto de professores formadores nas licenciaturas. Defendemos o diálogo entre os professores mais ligados à área da educação e os professores mais ligados à área de física. É preciso discutir a finalidade do curso de licenciatura, a sua necessária revisão diante das mudanças educacionais mais amplas, e quais as possibilidades que o próprio conhecimento físico tem à disposição.

Para que o ensino da física na educação básica supere a 
tendência do ensino da física pela física, para que esse conhecimento tenha sentido também para os alunos que não pensam em prosseguir os estudos no campo das ciências exatas, vemos como necessária uma mudança na postura dos docentes formadores de professores, principalmente dos que ensinam física nesses cursos. Para além de fatores menos ligados à formação inicial como a valorização da profissão professor com o pagamento de melhores as ]arios e melhores condições de trabalho, é preciso que a formação de professores assuma responsabilidades.

É preciso acabar com os espaços de isolamento no currículo e nas práticas dos professores formadores. Só assim seria possível criar a autonomia de que estamos falando, a que não se define pela capacidade de evitar ingerências, mas sim a que se funda nas responsabilidades assumidas. A formação de professores precisa ser vista como uma tarefa social da qual se é publicamente responsável. 


\section{CAPÍTULO 9}

\section{Considerações (EN)Fi(IM)nais}

No princípio era o caos

Ou é agora?

Brincadeira tem hora!

Eu dou meu testemunho:

Isso que está aí

é apenas um rascunho

Millôr Fernandes

Ao longo desse trabalho buscamos colocar em destaque uma certa problematização referente aos cursos de licenciatura em física, para além daquelas que tradicionalmente são tratadas no campo da pesquisa em formação de professores. Construímos um aporte teórico com algumas reflexões introduzidas pelas áreas de conhecimento de currículo e de formação de professores e, a partir desses olhares, percorremos diferentes âmbitos de investigação.

Consideramos que uma das contribuições desse trabalho está, justamente, no aporte teórico que evidenciou a necessidade de entrelaçar duas áreas de conhecimento tradicionalmente distintas. Acreditamos que esse olhar híbrido possibilite interessantes caminhos de pesquisa, especialmente no que diz respeito às licenciaturas.

É claro que a opção por um estudo que é bem mais transversal do que vertical impõem limites ao trabalho. Ao optarmos por adentrar áreas distintas, com certeza, não nos foi possível aprofundar cada uma delas, nem ampliar as possibilidades de consideração de seus diferentes autores. Reconhecemos que, com isso, o panorama que apresentamos das áreas de currículo e formação de professores é bastante parcial, até pelo fato 
de não termos optado por um foco específico.

A partir do desenho teórico que fizemos tendo como referência essas duas áreas, percorremos diferentes âmbitos de investigação num percurso que procurou ir do geral e abstrato ao mais concreto e específico.

A fim de compreender como alguns paradigmas hoje persistentes na educação e na formação docente se estabeleceram, buscamos uma compreensão histórica, ainda que breve, na qual procuramos identificar relações entre os processos pelos quais passam, conjuntamente, a educação básica, o ensino de ciências e a formação de professores. Consideramos, também, que essas correlações podem iluminar possíveis caminhos de pesquisa.

Nesse sentido, é preciso destacar novamente a limitação de nossa pesquisa, agora quanto à superficialidade dos estudos "históricos". Seria necessário buscar mais fontes e documentos originais, mas, novamente, a amplitude pela qual optamos nos impôs limites quanto ao aprofundamento em cada tema. Por outro lado, é justamente o processo, entendido em sua abrangência maior, que nos permite perceber as perspectivas que sinalizam a necessidade e a possibilidade de mudanças.

Nesse sentido, procuramos destacar o caráter recente das Novas Diretrizes Curriculares para a Educação Básica de 2002, e o incorporamos na análise, destacando suas múltiplas facetas como indutor de novas práticas. As correlações entre as instâncias da escola básica, do ensino de ciências e da formação de professores, na forma de processo, nos levam a enfatizar a complexidade da situação trazida pelas diretrizes e que tenta reverter paradigmas profundamente arraigados, como o modelo "3+1". Embora busque essa reversão, no entanto, há lacunas nessas diretrizes que podem, ao mesmo tempo, inviabilizá-las.

E esse paradigma, que separa de forma persistente os âmbitos da formação, pensando o conhecimento específico e o conhecimento pedagógico do professor como se fossem independentes, parece também estar presente de certa forma nas pesquisas em ensino de ciências. Quando se definem as escolhas de pesquisa e as abordagens, detectamos que quase não se pensa o saber específico dentro da formação de professores.

Um dos indicativos, que está presente na abordagem da 
pesquisa em ensino de ciências e se mostra também significativo dentre as pesquisas que pensam as licenciaturas de forma mais específica, é a exaltação do potencial das disciplinas integradoras no currículo e das áreas de "ensino de", como se essas fossem a solução para remediar a fragmentação que se apresenta entre os saberes que compõem os currículos de licenciatura.

Nossa análise procura, por outro lado, enfatizar a parcialidade de tal solução, uma vez que, ao voltar o foco das pesquisas e da construção de conhecimento aos saberes integradores, não se questiona o cerne do problema que é a fragmentação em si.

$\mathrm{Na}$ tentativa de investigar aspectos ainda mais concretos, buscamos trazer o âmbito de investigação para o curso de licenciatura do IFSP, no qual procuramos identificar as influências da instituição e dos sujeitos envolvidos. Novamente, destacamos que essa etapa de pesquisa apresenta limitações, uma vez que optamos por um estudo muito amplo, e a empiria constitui apenas mais um âmbito de investigação e não o foco principal do trabalho. Embora um estudo detalhado da realidade ali apresentada pudesse ser muito interessante, acreditamos que o recorte adotado é suficiente para iluminar importantes possibilidades e perspectivas para realizações inovadoras em realidades concretas.

A partir de todos esses elementos, passamos a um questionamento do status do conhecimento físico no interior dos currículos dos cursos de licenciatura em física, chamando atenção para seu caráter de construção histórico-social e para a questão das finalidades, muitas vezes oculta. E ao problematizar as finalidades, evocamos a concepção de professor autônomo e a perspectiva da educação como prática emancipadora.

Lançar um olhar crítico do currículo sobre as licenciaturas nos exige ter clareza quanto às finalidades formativas. E pensando as finalidades de um curso dessa natureza, reiteramos a necessidade de refletir sobre 0 currículo em sentido global, pensando os conhecimentos da formação de professores de forma articulada com os saberes que são objeto de ensino.

$\mathrm{E}$ isso exigiria um esforço de ambas as áreas de conhecimento que compõem historicamente um curso de licenciatura em física, a área de física e a área de educação, ou seja é preciso repensar os saberes de física e os saberes pedagógicos no interior do currículo. 
Fazer essa articulação passa então por desnaturalizar os saberes de física no currículo, ou seja, passa pelo entendimento de que mesmo as disciplinas de físicas mais comuns são tradições consolidadas e que, portanto, podem ser questionadas, revistas e modificadas.

Chamamos a atenção, então, para o fato de que é preciso repensar os saberes de física nos cursos de formação de professores pautados por uma finalidade que reside numa concepção docente.

E a finalidade de um curso de licenciatura é formar professores para a educação básica. É preciso introduzir, portanto, a reflexão sobre o que se espera da educação e sobre qual o papel da física nesse projeto educativo, no próprio momento da formação inicial. E é a consciência desses aspectos que deve balizar quais são os conhecimentos de física e a forma como eles se encontrarão estruturados no currículo.

Além disso, pensar as finalidades de um curso de licenciatura requer uma reflexão sobre o professor que se deseja formar. É preciso ter clareza quanto ao que se espera do futuro professor mediante o projeto educativo que se assume para a escola básica. E todo o currículo do curso deve responder a essas finalidades no sentido dos saberes selecionados, da articulação desses saberes e das estratégias escolhidas.

É preciso ainda ter em mente que as escolhas que balizam a tomada de consciência sobre as finalidades de um curso de formação de professores, como as concepções de educação, de conhecimento e do que é "ser professor", são escolhas eminentemente políticas e éticas, que refletem compreensões acerca do que se espera do mundo e das pessoas.

Enfatizamos ainda que, embora a análise aqui apresentada pretenda extrapolar limites que mapeamos existirem na área de formação de professores e na área de ensino de ciências, só nos é possível tecer as críticas aqui presentes graças às décadas de trabalho acumuladas por essas áreas. $\mathrm{O}$ avanço das concepções e práticas ligadas à formação de professores é que nos permite chegar, hoje, a uma possibilidade crítica.

Esperamos que esse trabalho venha a contribuir para encorajar novas práticas, que incorporem o conhecimento físico nos currículos das licenciaturas de forma ativa, propositiva e criativa. Esperamos que contribua, também, para estimular novas pesquisas, que aprofundem as 
questões que foram aqui apenas sinalizadas. Defendemos que é preciso "reinventar a física" presente nos cursos de licenciatura, para que se possam atingir novas perspectivas na formação do professor e no ensino de física da educação básica.

Diante do projeto que desejamos para a educação básica, assumindo uma perspectiva crítica e, portanto, desejando mudanças e a construção de uma realidade social mais justa, argumentamos em prol de uma formação em física que preze pela autonomia do futuro professor, para o entendimento de uma ciência que é parte da cultura, e de que a física possa vir a estar, por meio de um projeto educativo, a serviço de uma transformação de mundo. 


\section{REFERÊNCIAS}

ABIB, M.L.V.S. Em busca de uma nova formação de professores. Ciência\&Educação, Bauru, V. 3, p.60-72, 1996.

. Construção de conhecimentos sobre ensino na formação inicial do professor de física. Tese (Doutorado em Educação) - Faculdade de Educação da Universidade de São Paulo, São Paulo, 1997.

AIRES, J. A.; ERN, E. As pesquisas em história das disciplinas escolares podem problematizar a história hegemônica do ensino de ciências brasileiro: 0 que havia antes do "Sputnik"? Atas do V ENPEC, Bauru, 2005.

ALMEIDA, M.J.P.M. Uma concepção curricular para formação do professor de física. Revista Brasileira de Ensino de Física, vol 14, №3, 1992.

ALVES, M. R. F. Multiculturalismo e Formação de Professores: um Estudo das Diretrizes Curriculares Nacionais Para o Curso de Pedagogia. Tese (Doutorado), Universidade Federal do Rio de Janeiro, Rio de Janeiro, 2010.

AMATO, M.A. e SOUZA, C.M.S.G. Um curso noturno de licenciatura em física: a elaboração do currículo. Revista Brasileira de Ensino de Física, vol 14, ํ3, 1992.

ANDRE, M.; SIMÕES, R.H.S.; CARVALHO, J.M.; BRZEZINSKI, I. Estado da Arte da Formação de Professores no Brasil. Educação \& Sociedade, № 68, dez. 1999.

APPLE. M. Repensando Ideologia e Currículo. In: Antônio Flávio Moreira e Tomaz Tadeu da Silva (Orgs) Currículo, Cultura e Sociedade. São Paulo, Cortez, 1994.

. M. Ideologia e Currículo. Porto Alegre, Artmed, 2006.

ARAÚJO, R.S.; VIANNA, D.M. A formação de professores de Física no Brasil sob uma perspectiva histórica. Atas do SIEF 9, Rosário, 2008a.

Aspectos históricos da remuneração dos professores de física do Brasil e da carência deste profissional na educação básica frente à realidade da OECD. Atas do SIEF 9, Rosário, 2008. 
ARROIO A. Formação docente para o ensino superior em química. Atas do VII ENPEC, Florianópolis, 2009.

BACHELARD, G. - Epistemologia. Trechos escolhidos por D. Lecourt. Zahar Editores, Rio de Janeiro, 1977.

BARDIN, L. Análise de Conteúdo, Lisboa, Edições 70, 2008.

BARREIRO, A.C.M. Licenciatura em Física: Uma Proposta. Revista Brasileira de Ensino de Física, vol 14, ㄲo3, 1992.

BERLITZ, A.M.J. OSTERMANN, F. Pesquisa em ensino de física e formação de professores: uma integração possível a partir da disciplina de metodologia de ensino de física I. Atas do V ENPEC, Bauru, 2005.

BIASUS, G. G. Formação de Professores nas Instituições Federais de Ensino Superior do Estado do RS: Um Estudo Multicasos. Dissertação de Mestrado, UFSM, 2006.

BORGES C. Saberes Docentes: Diferentes Tipologias e Classificações de um Campo de Pesquisa. Educação \& Sociedade, ano XXII, no 74, Abril/2001.

BRASIL. Decreto-Lei o 1.190, de 4 de Abril de 1939: Dá organização à Faculdade Nacional de Filosofia. Congresso Nacional. Disponível em http://www2.camara.leg.br/legin/fed/declei/1930-1939/decreto-lei-1190-4-abril1939-349241-publicacaooriginal-1-pe.html

. Lei № 5692, de 11 de agosto de 1961. Fixa diretrizes e bases para 0 ensino do $1^{\circ}$ e $2^{\circ}$ grau, e dá outras providências. Brasília: Congresso Nacional. Disponível em: https://www.planalto.gov.br/ccivil_03/leis/15692.htm

Disponível

Constituição da República Federativa do Brasil de 1988.

https://www.planalto.gov.br/ccivil_03/Constituicao/Constitui\%E7ao.htm

em:

. Lei no 9.394, de 20 de dezembro de 1996: Estabelece as diretrizes e bases da educação nacional. Congresso Nacional. Disponível http://www.planalto.gov.br/ccivil_03/leis/L9394.htm.

Secretaria de Educação Média e Tecnológica. Parâmetros Curriculares Nacionais. PCN Ensino Médio. Brasília: MEC, SEMTEC, 2000. 
- Conselho Nacional de Educação. Parecer N N.: CNE/CES 1.304/2001, aprovado em 06 de novembro de 2001, Diretrizes Nacionais Curriculares para os Cursos de Física - Homologado em 4/12/2001, publicado no DOU em 7/12/2001.

. Conselho Nacional de Educação. Parecer CNE/CP no 009, aprovado em 8 de maio de 2001, Diretrizes Curriculares Nacionais para a Formação de Professores da Educação Básica, em nível superior, curso de licenciatura, de graduação plena - Homologado em 17/01/2002, publicado no DOU em 18/01/2002.

. Conselho Nacional de Educação. Parecer CNE/CP 28/2001, aprovado em 02/10/2001, Dá nova redação ao Parecer CNE/CP 21/2001, que estabelece a duração e a carga horária dos cursos de Formação de Professores da Educação Básica, em nível superior, curso de licenciatura, de graduação plena - Homologado em 17/01/2002, publicado no DOU em 18/01/2002.

. Conselho Nacional de Educação. Resolução CNE/CP 1, de 18 de fevereiro de 2002, Institui Diretrizes Curriculares Nacionais para a Formação de Professores da Educação Básica, em nível superior, curso de licenciatura, de graduação plena

Conselho Nacional de Educação. Parecer CNE/CP 28/2001, aprovado em 02/10/2001, Dá nova redação ao Parecer CNE/CP 21/2001, que estabelece a duração e a carga horária dos cursos de Formação de Professores da Educação Básica, em nível superior, curso de licenciatura, de graduação plena - Homologado em 17/01/2002, publicado no DOU em 18/01/2002.

- Secretaria de Educação Média e Tecnológica. Parâmetros Curriculares Nacionais. PCN+ Ensino Médio. Brasília: MEC, SEMTEC, 2002.

BROCKINGTON, G; PIETROCOLA, M. Serão as regras da transposição didática aplicáveis aos conceitos de física moderna? Investigações em Ensino de Ciências, V10(3), pp. 387-404, 2005.

BRUNER, J. O processo da educação. São Paulo, Editora Nacional, 1987.

BRZEZINSKI, Iria e GARRIDO, Elsa. Análise dos trabalhos do GT Formação de Professores: o que revelam as pesquisas do período 1992-1998. In: Revista Brasileira de Educação, set/out/nov/2001, no 18, p. 82-100. 
CARVALHO, A. M. P. Reformas nas licenciaturas: a necessidade de uma mudança de paradigma mais do que de mudança curricular. Em Aberto, Brasília, ano 12, n.54, abr.jun. 1992.

CEFETSP. CENTRO FEDERAL DE EDUCAÇÃO TECNOLÓGICA DE SÃO PAULO Projeto do curso de Formação de Professores da Educação Básica, em nível superior, curso de licenciatura em Física, de graduação plena. São Paulo, 2003.

CHERVEL A. História das disciplinas escolares: reflexões sobre um campo de pesquisa. Teoria e Educação, ㄲo2, p. 177-277, Goiânia, 1992.

CHEVALLARD. Y.. La transposición didáctica: del saber sabio al saber enseñado. Buenos Aires: Aique, 1998.

CONTRERAS, J. Autonomia de Professores. Editora Cortez. São Paulo, 2002.

CORTELA, B.S.C. Formadores de professores de física: uma análise de seus discursos e como podem influenciar na implantação de novos currículos. Dissertação de Mestrado - UNESP Bauru, 2004.

DELIZOICOV, D. Articulando teoria e prática: desafios para o ensino e a pesquisa. Mesa redonda realizada no XI EPEF, Curitiba 2008.

DELIZOICOV, D.; ANGOTTI, J. A.; PERNANBUCO, M. M. Ensino de Ciências: fundamentos e métodos. São Paulo: Editora Cortez, 2002.

DIAS E. R. O Currículo como uma Política Cultural Pública. Atas IX Colóquio Luso-brasileiro sobre questões curriculares. Porto, 2010.

FÁVERO, M. L. A. Da Cátedra universitária ao departamento: subsídios para discussão. 23ํㅡㄹ Reunião Anual da ANPED. Caxambu, 2000.

FEYRABEND, P. Contra o Método. Francisco Alves, Rio de Janeiro, 1977.

FOURQUIN J-C. Saberes Escolares, Imperativos Didáticos e dinâmicas sociais. Teoria e Educação, ㄲo5, p.28-49, 1992.

Escola e Cultura: as bases epistemológicas do conhecimento escolar. Porto Alegre, Artes Médicas, 1993.

FREIRE, P. Extensão ou Comunicação? Rio de Janeiro, Paz e Terra, 1977. 
Pedagogia da Autonomia. São Paulo, Paz e Terra, 1996.

FERREIRA, M. S.; MOREIRA A.F.B. A história da disciplina escolar ciências nas dissertações e teses brasileiras no período 1981-1995. Revista Ensaio v.3 n.1, jun 2001.

GARCIA J. E. Hacia uma teoria alternativa sobre los contenidos escolares. Sevilla. Díada editorial S.L., 1998.

GARCIA N; GARCIA T.M.F.B. Licenciatura em física: construindo novas práticas. Atas do IX EPEF, Jaboticatubas, 2004.

GARCIA N.; HIGA, I. Formação de professores de Física: problematizando ações governamentais. Educação: Teoria e Prática, Vol. 22, n. 40, 2012.

GATTI B. A. Análise das políticas públicas para formação continuada no Brasil, na última década. Revista Brasileira de Educação v. 13 n. 37 jan./abr. 2008.

. Formação de professores: condições e problemas atuais. Revista Brasileira de Formação de Professores, vol 1, №1, Rio de Janeiro, 2009.

Formação de professores no Brasil:características e problemas. Educação e Sociedade, v. 31, n. 113, p. 1355-1379, Campinas 2010.

GATTI B. A ; BARRETTO E. S., Professores do Brasil: impasses e desafios. UNESCO Representação no Brasil, Brasília, 2009.

GATTI B. A ; BARRETTO E. S.; ANDRÉ, M. Políticas docentes no Brasil: um estado da arte. UNESCO Representação no Brasil, Brasília, 2011.

GIROTTO JUNIOR, G.; FERNANDES, C. Reflexão e Desenvolvimento do Conhecimento Pedagógico do Conteúdo: de Licenciando a Professor de Química. Florianópolis, Atas do VII ENPEC, 2009.

GIROUX H. A. Os Professores como Intelectuais: rumo a uma pedagogia crítica da aprendizagem. Porto Alegre, Artmed, 1997.

GOBARA S.T. ; GARCIA, J.R.B. As licenciaturas em física das universidades brasileiras: um diagnóstico da formação inicial de professores de física. Revista Brasileira de Ensino de Física, v. 29, n. 4, p. 519-525, (2007). 
GOODSON, I. F. Tornando-se uma matéria acadêmica: padrões de explicação e evolução. Teoria e Educação, n.2, p.230-254, 1990.

. Currículo: Teoria e História. Petrópolis: Vozes. 2008a.

As Políticas de Currículo e de Escolarização. Petrópolis, Vozes,

2008.

GROSSMAN P. L.; WILSON, S. M.; SHULMAN, L. S. Profesores de Sustancia: el conocimiento de la Materia para la Enseñanza. Profesorado. Revista de currículum y formación del profesorado, ano 9, no 2, 2005.

HIGA, I. Visões De Professores Sobre Ciência: Elementos Para Repensar Os Cursos De Licenciatura Em Física. Tese de Doutorado. São Paulo : Faculdade de Educação - USP, 2005.

KAWAMURA, M.R. Um panorama evolutivo da educação científica e do ensino de Ciências no Brasil. (Comunicação interna). 2011.

KLIEBARD, H. M. Os Princípios de Tyler. In: MESSIK, R. G., PAIXÃO L.; BASTOS, R. L. (orgs). Currículo: Análise e Debate. Rio de Janeiro, Zahar, 1980.

KUHN, T. A Estrutura das Revoluções Científicas, Perspectiva, 2005.

LATOUR, B. A Esperança de Pandora, Bauru, EDUSC, 2001.

LIMA, M.C.B. A Modificação da disciplina de instrumentação para o ensino de física na UERJ. Revista Brasileira de Ensino de Física, vol 14, 꾸, 1992.

LOPES, A. C. Conhecimento escolar: ciência e cotidiano. Rio de Janeiro: EdUERJ., 1999.

Janeiro 2008.

Políticas de Integração Curricular. Editora da UERJ. Rio de

LUDKE M. O professor, seu saber e sua pesquisa. Educação \& Sociedade, ano XXII, no 74, 2001.

MARANDINO, M. A prática de ensino nas licenciaturas e a pesquisa em ensino de ciências: questões atuais. Cad.Bras.Ens.Fís.,v.20, n.2: p.168-193,ago.2003. 
MARTINS, P. L. O. e ROMANOWSKI, J. P. A Didática na Formação Pedagógica de Professores nas Novas Propostas para os Cursos de Licenciatura. Atas do XV ENDIPE. Belo Horizonte, 2010.

MESSICK R.G., PAIXÃO L, BASTOS L R. Currículo: análise e debate. Zahar, Rio de Janeiro, 1980.

MONTEIRO, A.M.F.C. Professores: Entre Saberes E Práticas. Educação \& Sociedade, ano XXII, № 74, p. 121-142, abr. 2001.

MOREIRA, A.F.B. e SILVA T. T. (Orgs.) Currículo, cultura e sociedade. Cortez, São Paulo, 1994.

MOREIRA, A.F.B. Currículos e Programas no Brasil. Papirus. Campinas. 1997.

Currículo e controle social. In MARLUCY, A. P (org). Antônio Flávio Barbosa Moreira: Pesquisador em Currículo. Autêntica. Belo Horizonte. 2010a.

A Configuração atual dos estudos curriculares: A crise da teoria crítica. In MARLUCY, A. P (org). Antônio Flávio Barbosa Moreira: Pesquisador em Currículo. Autêntica. Belo Horizonte. 2010b.

A recente produção científica sobre currículo e multiculturalismo no Brasil (1995-2000): avanços, desafios e tensões: A crise da teoria crítica. In MARLUCY, A. P (org). Antônio Flávio Barbosa Moreira: Pesquisador em Currículo. Autêntica. Belo Horizonte. 2010c.

NEVES. D. G. Contribuições da Disciplina de Elementos e Estratégias para o Ensino de Física no Curso de Licenciatura do IFUSP. Tese de Doutorado Instituto de Física da USP, 2003.

NUNES, C. M. F. Saberes docentes e formação de professores: Um breve panorama da pesquisa brasileira. Educação e Sociedade, n. 74, ano XXII, p. 27-42, abr. 2001.

OLIVEIRA, R.V. O Professor de Física e sua Prática: perspectivas de uma reelaboração crítica. Tese de Doutorado, São Paulo - Instituto de Física da USP, 2006. 
PASSOS, G. P. ; DEL PINO, J. C. O curso de licenciatura em química da ufrgs, sob o olhar de seus discentes e docentes. Atas do VII ENPEC, Florianópolis, 2009.

PERRENOUD P. Construir competências é virar as costas aos saberes? Pátio. Revista Pedagógica, 1999

Ensinar: agir na urgência, decidir na incerteza. Artmed Editora.

Porto Alegre. 2001.

POTENZA, B.G.G. Formação Inicial de Professores e a Física Moderna: articulações para um desempenho autônomo. Dissertação de Mestrado, São Paulo- Instituto de Física da USP, 2011.

RAMOS, M. N. A Pedagogia das Competências: autonomia ou adaptação? Cortez, São Paulo, 2001.

SALEM, S. Perfil, evolução e perspectivas da Pesquisa em Ensino de Física no Brasil. Tese de doutorado, São Paulo - Instituto de Física da USP, 2012.

SANTOS, N .F. A formação inicial de professores de física em Centros Federais de Educação Tecnológica: contribuições e críticas. Dissertação de Mestrado, Rio de Janeiro, Universidade do Estado do Rio de Janeiro, 2004.

SAVIANI, D. Formação de professores: aspectos históricos e teóricos do problema no contexto brasileiro. Revista Brasileira de Educação v. 14, n. 40, p.143-155, jan./abr. 2009

SCHON, D. The reflective practioner. How professionals think ia action. Londres, Temple Smith, 1983.

SHULMAN, L. S. Conocimiento y Enseñanza: Fundamentos de la Nueva Reforma. Profesorado. Revista de currículum y formación del profesorado, ano 9, ํㅡ 2, 2005.

SILVA, J. C.. Um exemplo do uso da história e filosofia de física: disciplina FEP156 - Gravitação. Dissertação de Mestrado - Instituto de Física Faculdade de Educação da Universidade de São Paulo, São Paulo, 1998.

SILVA, M. A. A Atual legislação educacional brasileira para formação de professores: origens, influências e implicações nos cursos de licenciatura em matemática. Dissertação de Mestrado - PUC/SP, 2004. 
SILVA, D. M. H. G. F. Política de Formação de professores no Brasil: as ciladas da reestruturação das licenciaturas. Perspectiva. Florianópolis, v.23, n.02, p. 381-406, jul/dez. 2005.

SILVA, A. C. R. Abordagem curricular por competências no ensino superior: um estudo exploratório nos cursos de Administração, Ciências Contábeis e Economia no Estado da Bahia - Brasil. Tese de Doutorado, Universidade do Minho, 2006.

SILVA, M.H.G.F.; ROMANATTO, M.C.; SOSSOLOTE, C.C; INFORSATO, E.C.; CHAKUR, C.R.S.L.; CUSINATO, R., MUZETTI, L.R.; OLIVEIRA, J.K. A reestruturação das Licenciaturas: alguns princípios, propostas e (pré)condições institucionais. Rev. Diálogo Educ., Curitiba, v. 8, n. 23, p. 15-37, jan./abr. 2008

SILVA SÁ, C.S.; DOS SANTOS, W.L.P. A identidade de um curso de formação de professores de química. . Atas do VII ENPEC, Florianópolis, 2009.

SILVA. T.T. Documentos de Identidade, Uma introdução as teorias do Currículo. Ed. Autêntica. Belo Horizonte, 2010.

SOUZA R. F. História da organização do trabalho escolar e do currículo no século XX: Ensino primário e secundário no Brasil. São Paulo: Cortez, 2008.

TARDIF M. Saberes Docentes e Atuação Profissional. Editora Vozes, 2010.

TYLER.R .Princípios básicos de currículo e ensino. Porto Alegre: Globo, 1989.

TERRAZZAN, E A.; DUTRA, B. E. F.; WINCHC, P. G.; DA SILVA, A. A. Configurações curriculares em cursos de licenciatura e formação identitária de professores. Rev. Diálogo Educ., Curitiba, v. 8, n. 23, p. 71-90, jan./abr. 2008

VEIGA, I. P. A. Formação e desenvolvimento profissional docente. Passo Fundo: UPF (ATAS DO VI Encontro Anpae Região Sul), 2007

VICENTINI, P. P.; LUGLI, R G. História da Profissão Docente no Brasil: representações em disputa.São Paulo: Cortez, 2009.

VILLANI, A. O currículo de Licenciatura em Física: Diretrizes. Revista de Ensino de Física, vol 10, 1988.

. O currículo de Licenciatura em Física: Objetivos, Conteúdos e Atividades. Revista Brasileira de Ensino de Física, vol 11, 1989. 
O currículo de Licenciatura em Física: Um exemplo Concreto. Revista Brasileira de Ensino de Física, vol 12, 1990.

ZANETIC, J. Física Também é Cultura. Tese de doutorado, Faculdade de Educação - USP, São Paulo, 1989.

Evolução dos Conceitos da Física. Notas de Aula, 1996.

ZIMMERMANN, E.; BERTANI, J.A. Um novo olhar sobre os cursos de formação de professores. Cad.Bras.Ens.Fís., v.20, n.1: 43-62, abr. 2003 
ANEXO A -

\section{Relação de Trabalhos e Autores}

\begin{tabular}{|c|c|c|c|}
\hline$n^{\circ}$ & Identificação & Artigo & Autores \\
\hline 1 & ENPEC 2007 - 1 & ARGUMENTACCÃO E ABORDAGEM CONTEXTUAL: ENSINANDO A SÍNTESE NEWTONIANA & $\begin{array}{l}\text { Elder Sales Teixeira, Climério Paulo da Silva Neto, Olival } \\
\text { Freire Jr. }\end{array}$ \\
\hline 2 & ENPEC 2007 - 2 & ATITUDES EM RELAÇÃO À HISTÓRIA DA CIÊNCIA: UMA AVALIACCÃO EM ESTUDANTES UNIVERSITÁRIOS & $\begin{array}{l}\text { Raquel Carmen de Oliveira Scoaris. Ana Maria Teresa } \\
\text { Benevides Pereira e Ourides Santin Filho }\end{array}$ \\
\hline 3 & ENPEC 2007 - 3 & $\begin{array}{l}\text { A CURIOSIDADE EPISTEMOLÓGICA NA FORMAÇ̃̃O INICIAL DO PROFESSOR E PESQUISADOR EM ENSINO DE FÍSICA: } \\
\text { POSSIBILIDADES E LIMITES }\end{array}$ & Dayane Rejane Andrade Maia, Rejane Aurora Mion \\
\hline 4 & ENPEC 2007 - 4 & $\begin{array}{l}\text { A ELETRICIDADE ESTÁTICA: OS OBSTÁCULOS EPISTEMOLÓGICOS, AS CONCEPÇÕES ESPONTÂNEAS, O CONHECIMENTO } \\
\text { CIENTÍFICO E A APRENDIZAGEM DE CONCEITOS }\end{array}$ & $\begin{array}{l}\text { Moacir Pereira de Souza Filho, Sérgio Luiz Bragatto Boss, } \\
\text { João José Caluzi }\end{array}$ \\
\hline 5 & ENPEC $2007-5$ & A FILOSOFIA DA CIÊNCIA COMO UM SABER NECESSÁRIO PARA A TEORIZAÇÃO DA PRÁTICA DOCENTE & Helenara Regina Sampaio, Irinéa L. Batista \\
\hline 6 & ENPEC 2007 - 6 & $\begin{array}{l}\text { A FORMAÇÃO DE PROFESSORES DAS CIÊNCIAS NO SÉCULO XXI: COMPREENDENDO O SIGNIFICADO DE ENSINARE } \\
\text { APRENDER CIÊNCIAS DA NATUREZA }\end{array}$ & Patricia Sessa, Rosália M. R. de Aragão \\
\hline 7 & ENPEC $2007-7$ & A FORMAÇÃO INICIAL DE PROFESSORES DE FÍSICA A PARTIR A PRÁTICA DE PROJETOS & Giselle Faur de Castro, Gloria Queiroz \\
\hline 8 & ENPEC $2007-8$ & A FORMAÇÃO INICIAL DE PROFESSORES DE FISICA: UMA QUESTÃO DE ESTILO? & Ana Lúcia Pereira Baccon, Sergio de Mello Arruda \\
\hline 9 & ENPEC $2007-9$ & A HISTÓRIA E A FILOSOFIA DA CIÊNCIA EM UMA DISCIPLINA DE EVOLUÇÃO DOS CONCEITOS DA FíSICA & Ana Carolina Staub \\
\hline 10 & ENPEC 2007 - 10 & $\begin{array}{l}\text { A HISTÓRIA HIPOTÉTICA NA FÍSICA: DISTORÇÕES DA HISTÓRIA DA CIÊNCIA NOS LIVROS DIDÁTICOS SOBRE O } \\
\text { EXPERIMENTO DE OERSTED }\end{array}$ & $\begin{array}{l}\text { João José Caluzi, Moacir Pereira de Souza Filho, Sérgio Luiz } \\
\text { Bragatto Boss }\end{array}$ \\
\hline 11 & ENPEC 2007 - 11 & $\begin{array}{l}\text { A INTEGRAÇÃO ENTRE ATIVIDADES COMPUTACIONAIS E EXPERIMENTAIS: UM ESTUDO EXPLORATÓRIO NO ENSINO DE } \\
\text { CIRCUITOS CC E CA EM FÍSICA GERAL }\end{array}$ & $\begin{array}{l}\text { Pedro Fernando Teixeira Dorneles, Ives Solano Araujo, } \\
\text { Eliane Angela Veit }\end{array}$ \\
\hline 12 & ENPEC 2007 - 12 & AS CRENÇAS MOTIVACIONAIS DE LICENCIANDOS DE FÍSICA E SUA RELAÇÃO COM O SABER PROFISSIONAL & $\begin{array}{l}\text { Marcelo Alves Barros, Luciano Gonsalves Costa, Carlos } \\
\text { Eduardo Laburú, Lucas Campanholi Junior, Fábio Ramos da } \\
\text { cilva }\end{array}$ \\
\hline 13 & ENPEC 2007 - 13 & AS TECNOLOGIAS DE INFORMAÇÃO E COMUNICAÇÃO NO CURSO DE FÍSICA DA UEFS & $\begin{array}{l}\text { Dielson P. Hohenfeld, Jancarlos M. Lapa, Maria Cristina } \\
\text { Mesquita Martins }\end{array}$ \\
\hline 14 & ENPEC 2007 - 14 & CONFIGURAÇÕES CURRICULARES EM CURSOS DE LICENCIATURA E FORMAÇÃO IDENTITÁRIA DE PROFESSORES & $\begin{array}{l}\text { Eduardo A. Terrazzan, Edna Falcão Dutra, Paula Gaida } \\
\text { Winch, Andréia Aurélio da Silva }\end{array}$ \\
\hline
\end{tabular}




\begin{tabular}{|c|c|c|c|}
\hline 15 & ENPEC 2007 - 15 & $\begin{array}{l}\text { CONSTRUÇÃO E VALIDAÇÃO DE UM INSTRUMENTO DE AVALIAÇÃO DE ATITUDES FRENTE AO USO DE HISTÓRIA DA } \\
\text { CIÊNCIA NO ENSINO DE CIÊNCIAS }\end{array}$ & $\begin{array}{l}\text { Raquel Carmen de Oliveira Scoaris, Ana Maria Teresa } \\
\text { Benevides Pereira e Ourides Santin Filho }\end{array}$ \\
\hline 16 & ENPEC 2007 - 16 & $\begin{array}{l}\text { CONTRIBUIÇÕES DOS PROJETOS DE ENSINO E PESQUISA NA FORMAÇÃO DO PROFESSOR DE CIÊNCIAS: COLETIVIDADE E } \\
\text { RUPTURA }\end{array}$ & Odisséa Boaventura de Oliveira, Ivanilda Higa \\
\hline 17 & ENPEC 2007 - 17 & $\begin{array}{l}\text { DISCURSOS PRESENTES EM UM PROCESSO DE REESTRUTURAÇÃO CURRICULAR DE UM CURSO DE LICENCIATURA EM } \\
\text { FÍSICA }\end{array}$ & Sérgio Camargo, Roberto Nardi \\
\hline 18 & ENPEC 2007 - 18 & ESTUDO DA EVASÃO NO CURSO DE LICENCIATURA EM FíSICA DO CEFET-GO & $\begin{array}{l}\text { Agnaldo Gonçalves Borges Junior, Ruberley Rodrigues de } \\
\text { Souza }\end{array}$ \\
\hline 19 & ENPEC 2007 - 19 & $\begin{array}{l}\text { FORMAS E FUNÇÕES DOS PROCESSOS AVALIATIVOS NA PERSPECTIVA DOS ALUNOS INGRESSANTES DO CURSO DE FÍSICA } \\
\text { DA UNIVERSIDADE FEDERAL DE SÃO CARLOS. }\end{array}$ & Ana Aleixo Diniz, Alice Helena Campos Pierson \\
\hline 20 & ENPEC 2007 - 20 & INDICADORES DE NEGOCIAÇÃO E FORMAÇÃO DE PROFESSORES DE FÍSICA & $\begin{array}{l}\text { Noemi Sutil, Paulo Cezar Santos Ventura, Rejane Aurora } \\
\text { Mion }\end{array}$ \\
\hline 21 & ENPEC 2007 - 21 & INTERACCÕES SOCIOTÉCNICAS NO DESENVOLVIMENTO DO CONHECIMENTO CIENTÍFICO-EDUCACIONAL & $\begin{array}{l}\text { Ingrid A. Carvalho, Rejane Aurora Mion, Carlos Alberto } \\
\text { Souza }\end{array}$ \\
\hline 22 & ENPEC 2007 - 22 & LINGUAGENS NA FÍSICA E NO SEU ENSINO: COMPREENDENDO O IMAGINÁRIO DE LICENCIANDOS EM FÍSICA & hirza Pavan Sorpreso, Maria José P. M. de Almeida \\
\hline 23 & ENPEC 2007 - 23 & $\begin{array}{l}\text { 'MEMÓRIAS': UMA METODOLOGIA DE COLETA DE DADOS PARA UM TRABALHO COM ORIENTADORES DE CAMPO NO } \\
\text { ESTÁGIO SUPERVISIONADO EM FÍSICA. }\end{array}$ & $\begin{array}{l}\text { Marinez Meneghello Passos, Simone Aparecida Prins, } \\
\text { Marcelo Alves de Carvalho, Sergio de Mello Arruda }\end{array}$ \\
\hline 24 & ENPEC 2007 - 24 & NATUREZA: OBJETO DE INTERESSE PARA PROFESSORES E CIENTISTAS? & $\begin{array}{l}\text { Carolina de Lima A. Belo, Eliane Brígida Morais Falcão, } \\
\text { Marta Feijó Barroso }\end{array}$ \\
\hline 25 & ENPEC 2007 - 25 & $\begin{array}{l}\text { O PROFESSOR REFLEXIVO E A FORMAÇÃO INICIAL DE PROFESSORES DE CIÊNCIAS: UMA ANÁLISE DA PRODUÇÃOO } \\
\text { RECENTE }\end{array}$ & Alisson Antonio Martins, Ivanilda Higa \\
\hline 26 & ENPEC 2007 - 26 & $\begin{array}{l}\text { PROCEDIMENTOS DISCURSIVOS DIDÁTICOS DE UM FORMADOR EM SITUAÇÕES ARGUMENTATIVAS NA FORMAÇÃOO } \\
\text { INICIAL DE PROFESSORES DE FÍSICA }\end{array}$ & Rodrigo Drumond Vieira, Silvania Sousa do Nascimento \\
\hline 27 & ENPEC 2007 - 27 & PROPOSTAS EDUCACIONAIS E FORMAÇÃO DE PROFESSORES DE FÍSICA & Noemi Sutil, Rejane Aurora Mion \\
\hline 28 & ENPEC 2007 - 28 & PROPUESTA DE MODALIDAD DE TRABAJO PRÁCTICO DE LABORATORIO PARA EL NIVEL UNIVERSITARIO BÁSICO & $\begin{array}{l}\text { Marisol Montino, Silvia M. Pérez, Diego Petrucci, José } \\
\text { Ernesto Ure }\end{array}$ \\
\hline 29 & ENPEC $2007-29$ & REFLEXOS DO REGIME DE TUTORIA NO DESEMPENHO DE ESTAGIÁRIOS EM ATIVIDADES DOCENTES & Andréia Aurélio da Silva, Eduardo Adolfo Terrazzan \\
\hline 30 & EPEF $2006-1$ & $\begin{array}{l}\text { A COMPARAÇÃO DAS VISÕES DE ENSINAR E DE APRENDER DE PROFESSORES DE FÍSICA EM FORMAÇÃO COM BASE NA } \\
\text { ABORDAGEM COMUNICATIVA }\end{array}$ & Esdras Viggiano e Cristiano Mattos \\
\hline 31 & EPEF $2006-2$ & A DIALÉTICA ENTRE FENÔMENOS ELÉTRICOS E MAGNÉTICOS E O ENSINO DO ELETROMAGNETISMO & Moacir Pereira de Souza Filho e João José Caluzi \\
\hline
\end{tabular}




\begin{tabular}{|c|c|c|c|}
\hline 32 & EPEF $2006-3$ & 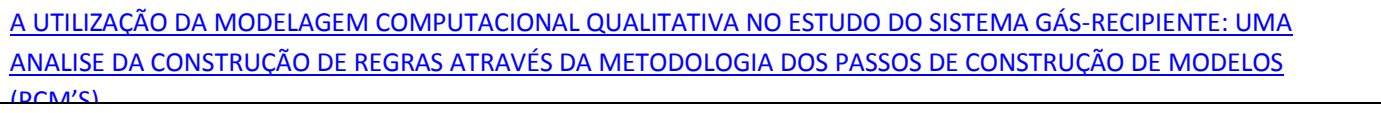 & Rafael Rodrigues \& Laércio Ferracioli \\
\hline 33 & EPEF 2006 - 4 & APRESENTACCÃO DISTORCIDA DA OBRA DE AMPÈRE NOS LIVROS DIDÁTICOS & J. P. M. C. Chaib e A. K. T. Assis \\
\hline 34 & EPEF $2006-5$ & $\begin{array}{l}\text { AVALIAÇÃO DE UM SISTEMA HIPERMÍDIA ENQUANTO RECURSO DIDÁTICO PARA O ENSINO DE CONCEITOS DE FÍSICA } \\
\text { MODERNA E SOBRE A NATUREZA DA CIÊNCIA }\end{array}$ & Daniel Iria Machado e Roberto Nardi \\
\hline 35 & EPEF $2006-6$ & ENGAJAMENTO INTERATIVO E MATURIDADE DOS ALUNOS NO CURSO DE FÍSICA BÁSICA & Diana E. Tuyarot e Jose R. Tagliati \\
\hline 36 & EPEF $2006-7$ & ETTORE MAJORANA: O DRAMA DE CONSCIÊNCIA DE UM JOVEM CIENTISTA & V. Morcelle, V. Campbell, O. A. P. Tavares e N. V. Vugman \\
\hline 37 & EPEF $2006-8$ & $\begin{array}{l}\text { FORMAÇÃO DE PROFESSORES: INTEGRANDO E COORDENANDO ENSINO, PESQUISA E EXTENSÃO NA CONSTRUÇÃO DE } \\
\text { UM PROFESSOR AUTÔNOMO: O CASO DO PROJETO EXPERIMENT }\end{array}$ & Ivan F. Costa, Elio Carlos Ricardo e Henrique César da Silva \\
\hline 38 & EPEF $2006-9$ & FORMACCÃO INICIAL DE UM PROFESSOR DE FÍSICA: ESTUDO DE CASO & Castro, G. F. \& Barbosa-Lima, M. C \\
\hline 39 & EPEF 2006 - 10 & $\begin{array}{l}\text { INTERPRETAÇÃO DOS DISCURSOS DE LICENCIANDOS SOBRE A UTILIZAÇÃO DE ANALOGIAS E METÁFORAS NO ENSINO } \\
\text { SUPERIOR DE FÍSICA }\end{array}$ & Fernanda Cátia Bozelli e Roberto Nardi \\
\hline 40 & EPEF $2006-11$ & $\begin{array}{l}\text { INVESTIGANDO O USO DO CICLO DA EXPERIÊNCIA KELLYANA NA COMPREENSÃO DO CONCEITO DE DIFRACCÃO DE } \\
\underline{\text { ELÉTRONS }}\end{array}$ & Marcos Antonio Barros e Heloisa Flora B. N. Bastos \\
\hline 41 & EPEF $2006-12$ & LA VISIÓN DE ESTUDIANTES UNIVERSITARIOS SOBRE LOS TRABAJOS PRÁCTICOS DE LABORATORIO DE FÍSICA & Diego Petrucci e José Ure \\
\hline 42 & EPEF $2006-13$ & MEDIDAS NO LABORATÓRIO E REALIDADE NA TEORIA & Fábio Marineli e Jesuína Lopes de Almeida Pacca \\
\hline 43 & EPEF $2006-14$ & NEGOCIAÇÕES NA ELABORAÇÃO DE PROPOSTAS EDUCACIONAIS NO ENSINO-APRENDIZAGEM DE FÍSICA & $\begin{array}{l}\text { Noemi Sutil, Rejane Aurora Mion e Paulo Cezar Santos } \\
\text { Ventura }\end{array}$ \\
\hline 44 & EPEF $2006-15$ & $\begin{array}{l}\text { O DISCURSO OFICIAL, O DISCURSO DOS FORMADORES E A DEMANDA DE LICENCIANDOS E PROFESSORES EM EXERCÍCIO } \\
\text { NA REESTRUTRUÇÃO DE UM PROJETO POLÍTICO-PEDAGÓGICO PARA FORMAÇÃO DE PROFESSORES DE FÍSICA }\end{array}$ & Sérgio Camargo a Roberto Nardi \\
\hline 45 & EPEF $2006-16$ & O ENSINO DE FÍSICA NA REGIÃO SUDOESTE DA BAHIA: HISTÓRICO E PERSPECTIVAS & $\begin{array}{l}\text { Ferdinand Martins da Silva, Jornandes Jesús Correia e } \\
\text { Joaquim Bonfim Santos Mendes }\end{array}$ \\
\hline 46 & EPEF $2006-17$ & $\begin{array}{l}\text { O TRABALHO COLABORATIVO EM REDE SÓCIOTÉCNICA NA FORMACC̃̃O DE PROFESSORES DE CNMT/FÍSICA (CIÊNCIAS DA } \\
\text { NATUREZA MATEMÁTICA E SUAS TECNOLOGIAS) }\end{array}$ & $\begin{array}{l}\text { Ingrid Aline de Carvalho, Carlos Alberto Souza e Rejane } \\
\text { Aurora Mion }\end{array}$ \\
\hline 47 & EPEF $2006-18$ & $\begin{array}{l}\text { PLANEJAMENTOS DE AULAS DE FÍSICA NA FORMAÇ̃̃O INICIAL: UMA ANÁLISE DO CONHECIMENTO PEDAGÓGICO DO } \\
\text { CONTEÚDO }\end{array}$ & Flávia Rezende, Leandro Rubino e Glória Queiroz \\
\hline 48 & EPEF $2006-19$ & PROFESSORES DE FÍSICA EM FORMAÇ̃̃O: A SALA DE AULA COMO ESPAÇO DE REFLEXÃO SOBRE AS PRÓPRIAS CRENCCAS & Maria Amélia Monteiro e Roberto Nardi \\
\hline
\end{tabular}




\begin{tabular}{|c|c|c|c|}
\hline 49 & EPEF $2006-20$ & $\begin{array}{l}\text { TRANSDISCIPLINARIDADE E FORMAÇÃO DE PROFESSORES: UMA PROPOSTA PARA O ENSINO DE FÍSICA, QUÍMICA E } \\
\text { CIÊNCIAS BIOLÓGICAS }\end{array}$ & $\begin{array}{l}\text { Edval Rodrigues de Viveiros e, Renato Eugênio da Silva } \\
\text { Diniz }\end{array}$ \\
\hline 50 & EPEF $2006-21$ & UM ESTUDO EXPLORATÓRIO SOBRE AS CRENCCAS EPISTEMOLÓGICAS DE INGRESSANTES DO ENSINO SUPERIOR & $\begin{array}{l}\text { Mariama Rebello de Souza Dias, Terezinha Correa Lindino e } \\
\text { Débora Coimbra }\end{array}$ \\
\hline 51 & EPEF $2006-22$ & $\begin{array}{l}\text { UM ESTUDO SOBRE A FORMAÇÃO DO PROFESSOR DE FÍSICA NO CONTEXTO DAS NECESSIDADES EDUCACIONAIS } \\
\text { ESPECIAIS DE ALUNOS COM DEFICIÊNCIA VISUAL }\end{array}$ & Marília * Camargo Eder Pires de e Nardi Roberto \\
\hline 52 & EPEF $2006-23$ & $\begin{array}{l}\text { USO DE FERRAMENTAS DE ANÁLISE NO CONTEXTO DAS DISCIPLINAS PEDAGÓGICAS E A FORMAÇÃO INICIAL DO } \\
\text { PROFESSOR DE FÍSICA }\end{array}$ & Ferreira, Marli C. Raboni e Paulo C. de A. \\
\hline 53 & EPEF $2006-24$ & $\begin{array}{l}\text { USO DE UM ESPAÇO VIRTUAL DE APRENDIZAGEM NA FORMAÇÃO INICIAL DE PROFESSORES DE FÍSICA: ESTUDANDO O } \\
\text { CURRÍCULO DE FÍSICA }\end{array}$ & Ernesto Macedo Reis e Marília Paixão Linhares \\
\hline 54 & EPEF $2006-25$ & $\begin{array}{l}\text { A ELABORACC̃̃ DE PROPOSTAS EDUCACIONAIS PARA O ENSINO-APRENDIZAGEM DE FÍSICA: POSSIBILIDADES E DESAFIOS } \\
\text { NA FORMAÇÃO DE PROFESSORES }\end{array}$ & Noemi Sutil e Rejane Aurora Mion \\
\hline 55 & ENPEC $2005-1$ & $\begin{array}{l}\text { A EVOLUÇÃO DAS CONCEPÇÕES DE FUTUROS PROFESSORES SOBRE A NATUREZA E AS FORMAS DE CONHECER AS IDÉIAS } \\
\underline{\text { DOS ALUNOS }}\end{array}$ & $\begin{array}{l}\text { João Batista Siqueira Harres, Michelle Camara Pizzato, Ana } \\
\text { Paula Sebastiany, Hugo Daniel Marin Sanabria, Flaviane } \\
\text { Dradohon }\end{array}$ \\
\hline 56 & ENPEC $2005-2$ & $\begin{array}{l}\text { A FÍ́SICA QUÂNTICA COMO UMA TRADICCÃO DE PESQUISA: UMA ANÁLISE A PARTIR DA EPISTEMOLOGIA DE LARRY } \\
\text { LAUDAN }\end{array}$ & Fernanda Ostermann e Sandra Denise Prado \\
\hline 57 & ENPEC $2005-3$ & A INSERÇÃO DE HISTÓRIA E FILOSOFIA DA CIÊNCIA NO ENSINO DE CIÊNCIAS E A FORMAÇÃO DE PROFESSORES DE FÍSICA & Katemari Rosa e Maria Cristina Martins Penido \\
\hline 58 & ENPEC $2005-4$ & $\begin{array}{l}\text { A INVESTIGACCÃO DAS RELAÇ̃̃ES ESTEBELECIDAS POR LICENCIANDOS EM FÍSICA ENTRE A ESTRUTURA DA MATÉRIA E AS } \\
\text { PROPRIEDADES MACROSCÓPICAS DOS MATERIAIS }\end{array}$ & $\begin{array}{l}\text { Rodrigo de Miranda Henriques Medeiros, Romildo } \\
\text { Albuquerque Nogueira e Helaine Sivini Ferreira }\end{array}$ \\
\hline 59 & ENPEC $2005-5$ & A PEDAGOGIA DAS SÉRIES INICIAIS DO CURSO DE FÍSICA & Gisele Duarte Caboclo, Rosana Santiago e Glória Queiroz \\
\hline 60 & ENPEC $2005-6$ & $\begin{array}{l}\text { A PERCEPÇÃO DOS ALUNOS DA DISCIPLINA METODOLOGIA DE ENSINO DE FÍSICA SOBRE A INCORPORAÇÃO DE UMA } \\
\text { PLATAFORMA VIRTUAL DE APRENDIZAGEM COMO SUPORTE AO ENSINO PRESENCIAL }\end{array}$ & Maria Inês Martins \\
\hline 61 & ENPEC $2005-7$ & $\begin{array}{l}\text { A PRÁTICA REFLEXIVA E A TEORIA DO HABITUS, UM CAMINHO PARA O DESENVOLVIMENTO PROFISSIONAL DO } \\
\text { PROFESSOR }\end{array}$ & $\begin{array}{l}\text { Jayme Marrone Júnior, Alvaro Lorencini Júnior, Rute } \\
\text { Helena Trevisan }\end{array}$ \\
\hline 62 & ENPEC $2005-8$ & ABORDAGEM CTS NA FORMACCÃO DE PROFESSORES (INVESTIGADOR ATIVO) DE FÍSICA EM REDE SÓCIO-TÉCNICA & Ingrid Carvalho, Rejane Mion e Carlos A. Souz \\
\hline 63 & ENPEC 2005 - 9 & $\begin{array}{l}\text { ANÁLISE DO DESEMPENHO DE LICENCIANDOS NA APLICACCÃO DE UMA PROPOSTA DE ELETRODINÂMICA NO ENSINO } \\
\text { MÉDIO }\end{array}$ & Cléverson Mota Pereira eRoberto Nardi \\
\hline 64 & ENPEC 2005 - 10 & $\begin{array}{l}\text { AS CONCEPÇÕES PEDAGÓGICAS DE CIÊNCIA DE LICENCIANDOS EM FÍSICA E AS SUAS RELAÇÕES COM A FORMAÇÃO DO } \\
\text { SUJEITO PROPOSTA PELAS DIRETRIZES DOS PCNS DO ENSINO MÉDIO }\end{array}$ & $\begin{array}{l}\text { Rodrigo Drumond Vieira, Carlos Eduardo Porto Villani e } \\
\text { Silvania Sousa do Nascimento }\end{array}$ \\
\hline 65 & ENPEC 2005 - 11 & CONDIÇÕES DE PRODUCCÃ̃ DO ENSINO DE FÍSICA EM ESCOLAS DO INTERIOR PAULISTA E A FORMAÇÃO DOCENTE & Thirza Pavan Sorpreso e Maria José P. M. de Almeida \\
\hline
\end{tabular}




\begin{tabular}{|c|c|c|c|}
\hline 66 & ENPEC $2005-12$ & $\begin{array}{l}\text { CONSTRUTIVISMO - TEORIA E PRÁTICA: UM ESTUDO NA FACULDADE DE FORMAÇÃO DE PROFESSORES DA MATA SUL - } \\
\text { PALMARES - PE }\end{array}$ & $\begin{array}{l}\text { Lourival Gomes da Silva Filho, lara da Glória Maria da Silva } \\
\text { e Zélia Maria Soares Jófili }\end{array}$ \\
\hline 67 & ENPEC 2005 - 13 & CONVERGÊNCIAS TECNOLÓGICAS: FRONTEIRAS DA FORMAÇÃO DE PROFESSORES DE CIÊNCIAS & Ernesto Macedo Reis e Marília Paixão Linhares \\
\hline 68 & ENPEC 2005 - 14 & $\begin{array}{l}\text { DIFICULDADES E ALTERNATIVAS INICIAIS ENCONTRADAS POR LICENCIANDOS PARA A ELABORAÇÃO DE ATIVIDADES DE } \\
\text { ENSINO DE FÍSICA PARA ALUNOS COM DEFICIÊNCIA VISUAL }\end{array}$ & Eder Pires de Camargo e Roberto Nardi \\
\hline 69 & ENPEC 2005 - 15 & FÍSICA MODERNA E CONTEMPORÂNEA NO ENSINO MÉDIO: FORMAÇÃO OU INFORMAÇÃO? & $\begin{array}{l}\text { Mikael Frank Rezende Junior e Frederico Firmo de Souza } \\
\text { Cruz }\end{array}$ \\
\hline 70 & ENPEC 2005 - 16 & FORMAÇÃO INICIAL DE PROFESSORES DE FÍSICA: MARCAS DE REFERENCIAIS TEÓRICOS NO DISCURSO DE LICENCIANDOS & Sérgio Camargo e Roberto Nardi \\
\hline 71 & ENPEC 2005 - 17 & HISTÓRIA E FILOSOFIA DA CIÊNCIA NO ENSINO: O QUE PENSAM OS LICENCIANDOS EM FÍSICA DA UFRN & André Ferrer Pinto Martins \\
\hline 72 & ENPEC 2005 - 18 & $\begin{array}{l}\text { NEGOCIAÇÕES ENTRE ELEMENTOS EPISTEMOLÓGICOS E SOCIOLÓGICOS NO PROCESSO ENSINO-APRENDIZAGEM DE } \\
\text { FÍSICA }\end{array}$ & Noemi Sutil e Rejane Aurora Mion \\
\hline 73 & ENPEC 2005 - 19 & O CURSO DE FÍSICA DA UNIVERSIDADE FEDERAL DE ALAGOAS: SURGIMENTO, MUDANÇAS E CONCEPÇÕES & $\begin{array}{l}\text { José Isnaldo de L. Barbosa, Kleber Cavalcante Serra e Elton } \\
\text { Casado Fireman }\end{array}$ \\
\hline 74 & ENPEC $2005-20$ & $\begin{array}{l}\text { O DISCURSO OFICIAL, O DISCURSO DOS FÍSICOS E A DEMANDA DE LICENCIANDOS E PROFESSORES EM EXERCÍCIO NA } \\
\text { CONSTRUÇÃAO DE UM PROJETO POLÍTICO-PEDAGÓGICO PARA FORMAÇÃO DE PROFESSORES DE FÍSICA }\end{array}$ & Sérgio Camargo e Roberto Nardi \\
\hline 75 & ENPEC 2005 - 21 & $\begin{array}{l}\text { O ENSINAR NA VISÃO DE LICENCIANDOS EM FÍSICA: O PAPEL DO APRENDIZ, ABORDAGEM COMUNICATIVA E CONTEXTOS } \\
\underline{\text { DE ENSINO }}\end{array}$ & Esdras Viggiano e Cristiano Mattos \\
\hline 76 & ENPEC 2005 - 22 & O ESTÁGIO SUPERVISIONADO E A FORMAÇÃO DO PROFESSOR DE CIÊNCIAS & Polonia Altoé Fusinato \\
\hline 77 & ENPEC 2005 - 23 & O IMPACTO DA OBSERVACCÃO DE CLASSE DURANTE O ESTÁGIO SUPERVISIONADO DE FÍSICA & $\begin{array}{l}\text { Sergio de Mello Arruda, Ana Lucia Pereira Baccon, Cleber } \\
\text { Bossa Pires e João Susumu Murakami }\end{array}$ \\
\hline 78 & ENPEC 2005 - 24 & O LABORATÓRIO DIDÁTICO DE FÍSICA NO ENSINO SUPERIOR: CONTRASTES E TRANSFORMAÇÕES & $\begin{array}{l}\text { Inés Prieto Schmidt Sauerwein, Maria Regina Dubeux } \\
\text { Kawamura e Demétrio Delizoicov }\end{array}$ \\
\hline 79 & ENPEC $2005-25$ & O USO DE ANALOGIAS E METÁFORAS EM AULAS DE FÍSICA NO ENSINO SUPERIOR: ALGUMAS CONSIDERAÇÕES & Fernanda C. Bozelli e Roberto Nardi \\
\hline 80 & ENPEC 2005 - 26 & $\begin{array}{l}\text { OS OBSTÁCULOS EPISTEMOLÓGICOS DOS ESTUDANTES DO CURSO DE LICENCIATURA EM FÍSICA AO CLÁSSICO } \\
\text { EXPERIMENTO DE OERSTED }\end{array}$ & Moacir Pereira de Souza Filho e João José Caluzi \\
\hline 81 & ENPEC 2005 - 27 & $\begin{array}{l}\text { OS PARÂMETROS CURRICULARES NACIONAIS NA FORMAÇÃO INICIAL DOS PROFESSORES DAS CIÊNCIAS DO ENSINO } \\
\underline{\text { MÉDIO }}\end{array}$ & Elio Carlos Ricardo e Arden Zylbersztajn \\
\hline 82 & ENPEC 2005 - 28 & $\begin{array}{l}\text { PESQUISA EM ENSINO DE FÍSICA E FORMAÇÃO DE PROFESSORES: UMA INTEGRAÇÃO POSSÍVEL A PARTIR DA DISCIPLINA } \\
\text { DE METODOLOGIA DE ENSINO DE FÍSICA I }\end{array}$ & Angela Maria Jacobus Berlitz eFernanda Ostermann \\
\hline
\end{tabular}




\begin{tabular}{|c|c|c|c|}
\hline 83 & ENPEC $2005-29$ & REFORMAS CURRICULARES NA LICENCIATURA EM FÍSICA: AS INTENÇÕES LEGAIS E O DISCURSO DOS FORMADORES & Beatriz S. C. Cortela e Roberto Nardi \\
\hline 84 & ENPEC $2005-30$ & SITUAÇÕES DIDÁTICAS DIFERENCIADAS E SEU PAPEL NA FORMACCÃO INICIAL DE PROFESSORES DE FÍSICA. & $\begin{array}{l}\text { Sônia Maria S. C. de Souza Cruz, Mikael Frank Rezende } \\
\text { Junior, Frederico Firmo de Souza Cruz }\end{array}$ \\
\hline 85 & ENPEC 2005 - 31 & UM ESTUDO SOBRE A FUNCCÃO DO TÉCNICO DE UM LABORATÓRIO DIDÁTICO DE CIÊNCIAS & $\begin{array}{l}\text { Ferdinando Vinicius Domenes Zapparoli, Marcelo Alves } \\
\text { Barros, Sergio de Mello Arruda }\end{array}$ \\
\hline 86 & ENPEC $2005-32$ & UM MODELO PARA A ANÁLISE DA REGÊNCIA DE CLASSE NO ESTÁGIO SUPERVISIONADO DE FÍSICA & Ana Lucia Pereira Baccon, Sergio de Mello Arruda \\
\hline 87 & ENPEC $2005-33$ & UMA INTERPRETAÇÃO PARA DIFICULDADES ENFRENTADAS PELOS ESTUDANTES NUM LABORATÓRIO DIDÁTICO DE FÍSICA & Fábio Marineli, Jesuína Lopes de Almeida Pacca \\
\hline 88 & EPEF $2004-1$ & $\begin{array}{l}\text { A INTEGRAÇÃO DE UM AMBIENTE DE MODELAGEM COMPUTACIONAL QUANTITATIVO NO ESTUDO DO FENÔMENO DE } \\
\underline{\text { COLISÕES }}\end{array}$ & Mariana Rampinelli Fernandes e Laércio Ferracioli \\
\hline 89 & EPEF $2004-2$ & ANALOGIAS E METÁFORAS NO ENSINO DE FÍSICA: O DISCURSO DO PROFESSOR E O DISCURSO DO ALUNO & Fernanda Cátia Bozelli eRoberto Nardi \\
\hline 90 & EPEF $2004-3$ & DESEMPENHO CONCEITUAL DE ALUNOS DO MÉTODO DE ENGAJAMENTO INTERATIVO DO CURSO DE FÍSICA I DA UFJF & $\begin{array}{l}\text { Julie Remold, José Acacio de Barros, Francisléia Vieira } \\
\text { Vidal, Nilséia Aparecida Barbosa }\end{array}$ \\
\hline 91 & EPEF $2004-4$ & $\begin{array}{l}\text { DO ÁTOMO GREGO AO ÁTOMO DE BOHR: O PERFIL DE UM TEXTO PARA A DISCIPLINA EVOLUÇÃO DOS CONCEITOS DA } \\
\text { FÍSICA }\end{array}$ & Luiz O. Q. Peduzzi \\
\hline 92 & EPEF $2004-5$ & ENSINO DE FÍSICA: DA RESOLUÇÃO DE PROBLEMAS À FORMULAÇÃO DE QUESTÕES & André Bessadas Penna-Firme \\
\hline 93 & EPEF $2004-6$ & ESTRATÉGIAS DIDÁTICO-PEDAGÓGICAS NA FORMAÇÃO DE PROFESSORES DE FÍSICA & $\begin{array}{l}\text { Rejane Aurora Mion, José André Peres Angotti, Awdry } \\
\text { Feisser Miquelin }\end{array}$ \\
\hline 94 & EPEF $2004-7$ & EVOLUCC̃̃O INICIAL DAS CONCEPCCÕES DIDÁTICAS DE FUTUROS PROFESSORES DE FÍSICA, QUÍMICA E MATEMÁTICA & $\begin{array}{l}\text { João Batista Siqueira Harres, Michelle Camara Pizzato, } \\
\text { Magda Cristiane Fonseca, Tatiane Henz }\end{array}$ \\
\hline 95 & EPEF $2004-8$ & FORMAÇÃO INICIAL DE PROFESSORES DE FÍSICA: MARCAS DE REFERENCIAIS TEÓRICOS NO DISCURSO DE LICENCIANDOS & Sérgio Camargo, Roberto Nardi \\
\hline 96 & EPEF $2004-9$ & $\begin{array}{l}\text { INSTRUMENTAÇÃO PARA O ENSINO: INTEGRAÇ̃̃O DE NOVAS TECNOLOGIAS E PRODUÇÃO DE MATERIAL MULTIMÍDIA } \\
\text { NA FORMACCÃO DE PROFESSORES DE CIÊNCIAS }\end{array}$ & $\begin{array}{l}\text { Mônica Giacomassi de Menezes de Magalhães, Iria Müller } \\
\text { Guerrini, Dietrich Schiel }\end{array}$ \\
\hline 97 & EPEF $2004-10$ & LICENCIATURA EM FÍSICA: CONSTRUINDO NOVAS PRÁTICAS * & $\begin{array}{l}\text { Nilson Marcos Dias Garcia, Tânia Maria Figueiredo Braga } \\
\text { Garciab }\end{array}$ \\
\hline 98 & EPEF $2004-11$ & $\begin{array}{l}\text { NVESTIGAÇÃO-AÇÃO E A FORMAÇÃO DE PROFESSORES EM FÍSICA: O PAPEL DA INTENÇÃO NA PRODUÇÃ̃O DO } \\
\text { CONHECIMENTO CRÍTICO }\end{array}$ & Rejane Aurora Mion, José André Peres Angotti \\
\hline 99 & EPEF $2004-12$ & O ENSINO DE FÍSICA EM NÍVEL MÉDIO E OS PARÂMETROS CURRICULARES NACIONAIS NA FORMAÇÃO INICIAL & Elio Carlos Ricardoa Arden Zylbersztajnb \\
\hline
\end{tabular}




\begin{tabular}{|c|c|c|c|}
\hline 100 & EPEF $2004-13$ & O REFERENCIAL GEOCÊNTRICO NAS CONCEPÇ̃̃ES DE ESTUDANTES DO ENSINO SUPERIOR: UMA ABORDAGEM INICIAL & $\begin{array}{l}\text { Marcos Cesar Danhoni Neves, Edna Heloisa Schaeffer, } \\
\text { Franciana Pedrochi, Solange Oenning }\end{array}$ \\
\hline 101 & EPEF $2004-14$ & $\begin{array}{l}\text { OS OBJETIVOS DO LABORATÓRIO DIDÁTICO NA VISÃO DOS ALUNOS DO CURSO DE LICENCIATURA EM FÍSICA DA UNESP- } \\
\underline{\text { BAURU }}\end{array}$ & Nádia Alves Grandinia, Carlos Roberto Grandinib \\
\hline 102 & EPEF $2004-15$ & $\begin{array}{l}\text { UM EXEMPLO DO USO DE EXPERIMENTOS VIRTUAIS OBJETIVANDO A INTRODUÇÃO DE CONCEITOS DE MECÂNICA } \\
\text { QUÂNTICA NA DISCIPLINA DE ESTRUTURA DA MATÉRIA }\end{array}$ & Aline Fernanda Schuck, Agostinho Serrano \\
\hline 103 & EPEF $2004-16$ & UMA BREVE DISCUSSÃO SOBRE CAMPO ELETROMAGNÉTICO NA FORMAÇÃO DO PROFESSOR & $\begin{array}{l}\text { Maxwell Roger da P. Siqueira e Maurício Pietrocola P. de } \\
\text { Oliveira }\end{array}$ \\
\hline 104 & EPEF $2004-17$ & VISÕES DE PROFESSORES SOBRE A NATUREZA DA CIÊNCIA: RELACCÃO MODELO E REALIDADE & Ivanilda Higa e Yassuko Hosoume \\
\hline 105 & EPEF $2008-1$ & $\begin{array}{l}\text { ASPECTOS AFETIVO-COGNITIVOS NA APRENDIZAGEM E SUAS INFLUÊNCIAS NA ESCOLHA DA PROFISSÃO DE PROFESSOR } \\
\text { DE FÍSICA: UM EXEMPLO }\end{array}$ & Jackelini Dalria e Cristiano Rodrigues de Mattos \\
\hline 106 & EPEF $2008-2$ & AVALIANDO A UTILIZACCÃO DAS ZONAS DE PERFIL CONCEITUAL DE APRENDER E ENSINAR EM DIFERENTES CONTEXTOS & Esdras Viggiano e Cristiano Rodrigues de Mattos \\
\hline 107 & EPEF $2008-3$ & $\begin{array}{l}\text { ESTUDO COMPARATIVO SOBRE O CONCEITO DE FORÇA E VELOCIDADE ENTRE ALUNOS DOS CURSOS DE LICENCIATURA } \\
\text { EM FÍSICA DA UFSC NAS MODALIDADES PRESENCIAL E A DISTÂNCIA }\end{array}$ & Paulo José Sena dos Santos e Sônia Maria de Souza Cruz \\
\hline 108 & EPEF $2008-4$ & $\begin{array}{l}\text { REVITALIZAR LABORATÓRIOS PARA ENSINAR FÍSICA: POSSIBILIDADES DOS SOFTWARES DE AUTORIA EM ATIVIDADES } \\
\text { TEÓRICO-EXEPERIMENTAIS }\end{array}$ & $\begin{array}{l}\text { Mário José Van Thienen da Silva, José André Peres Angotti } \\
\text { e Rejane Aurora Mion }\end{array}$ \\
\hline 109 & EPEF $2008-5$ & LABORATÓRIO DIDÁTICO: IMPORTÂNCIA E UTILIZACCÃO NO PROCESSO ENSINO-APRENDIZAGEM & Nádia Alves Grandini e Carlos Roberto Grandini \\
\hline 110 & EPEF $2008-6$ & SOBRE AS COMPETÊNCIAS ENVOLVIDAS NO PROCESSO DE PROMOVER A APRENDIZAGEM SIGNIFICATIVA EM MECÂNICA & Sorandra Corrêa de Lima e Eduardo Kojy Takahashi \\
\hline 111 & EPEF $2008-7$ & UM LEVANTAMENTO DO APRENDIZADO DA DUALIDADE ONDA-PARTÍCULA EM CURSOS DE GRADUACC̃̃O & $\begin{array}{l}\text { Bruna Graziela Garcia Potenza, Pablo Teruo Siguematsu, } \\
\text { Maria Regina }\end{array}$ \\
\hline 112 & EPEF $2008-8$ & $\begin{array}{l}\text { ANÁLISE DAS ATIVIDADES IMPLEMENTADAS POR FUTUROS PROFESSORES EM UMA DISCIPLINA DE PRÁTICA } \\
\text { PEDAGÓGICA }\end{array}$ & 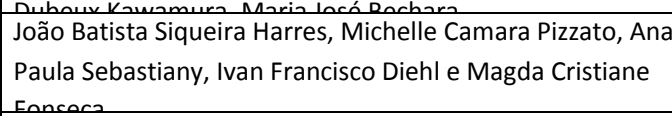 \\
\hline 113 & EPEF $2008-9$ & $\begin{array}{l}\text { ANÁLISE DISCURSIVA NA FORMAÇ̃̃O INICIAL DE PROFESSORES: UMA DISCUSSÃO CONCEITUAL SOBRE FÍSICA QUÂNTICA } \\
\text { MEDIADA POR UM INTERFERÔMETRO VIRTUAL DE MACH-ZEHNDER }\end{array}$ & $\begin{array}{l}\text { Alexsandro P. Pereira, Fernanda Ostermann, Cláudio } \\
\text { Cavalvanti }\end{array}$ \\
\hline 114 & EPEF $2008-10$ & $\begin{array}{l}\text { AVALIACCÕES DE ARGUMENTACCÃO DE LICENCIANDOS EM FÍ́SICA SOBRE UM EPISÓDIO DE ESTÁGIO CURRICULAR:EM QUE } \\
\text { CRITÉRIOS ELES SE BASEIAM? }\end{array}$ & Rodrigo Drumond Vieira, Silvania Sousa do Nascimento \\
\hline 115 & EPEF $2008-11$ & AVALIANDO A PRESENCCA DAS TIC NOS CURSOS DE FÍSICA DO IF-UFBA & $\begin{array}{l}\text { Dielson P. Hohenfeld, Jancarlos M. Lapa, Maria Cristina } \\
\text { Martins Penido }\end{array}$ \\
\hline 116 & EPEF $2008-12$ & CRENÇAS DE EFICÁCIA DE PROFESSORES DE FÍSICA E VARIÁVEIS DE CONTEXTO & $\begin{array}{l}\text { Fábio Ramos da Silva, Marcelo Alves Barros, Carlos } \\
\text { Eduardo Laburú, Lilian Cristiane Almeida dos Santos }\end{array}$ \\
\hline
\end{tabular}




\begin{tabular}{|c|c|c|c|}
\hline 117 & EPEF $2008-13$ & CURIOSIDADE EPISTEMOLÓGICA E A FORMAÇÃO DO PROFESSOR E PESQUISADOR EM ENSINO DE FÍSICA & Dayane Rejane Andrade Maia, Rejane Aurora Mion \\
\hline 118 & EPEF $2008-14$ & ESTÁGIO SUPERVISIONADO EM FÍSICA: A DURA REALIDADE & André Ferrer P. Martins \\
\hline 119 & EPEF $2008-15$ & ESTUDANDO O PROCESSO DE REESTRUTURAÇÃO CURRICULAR DE UM CURSO DE LICENCIATURA EM FÍSICA & Sérgio Camargo, Roberto Nardi \\
\hline 120 & EPEF 2008 - 16 & $\begin{array}{l}\text { FORMAÇÕES DISCURSIVAS PRESENTES NA INTERPRETACCÃO DE UM TEXTO SOBRE CIÊNCIA, TECNOLOGIA E ASPECTOS } \\
\text { SOCIAIS POR UM PROFESSOR UNIVERSITÁRIO }\end{array}$ & Luiz Eduardo Pedroso, Maria José P. M. de Almeida \\
\hline 121 & EPEF 2008 - 17 & $\begin{array}{l}\text { INVESTIGAÇÃO-AÇÃO EDUCACIONAL E FORMAÇÃO DE PROFESSORES DE FÍSICA: TECENDO ANÁLISES DA PRÓPRIA } \\
\text { PRÁTICA }\end{array}$ & Rejane Aurora Mion \\
\hline 122 & EPEF $2008-18$ & INVESTIGANDO AS CAUSAS DA EVASÃO NA LICENCIATURA EM FÍSICA DO CEFET-RN & Fernando Gomes, Dante Moura \\
\hline 123 & EPEF 2008 - 19 & MODELOS DE ENFRENTAMENTO DE PROBLEMAS NA ARTICULAC̄̃̃O DA FORMACCÃO INICIAL À CONTINUADA & Sandro Rogério Vargas Ustra, Claudio Luiz Hernandes \\
\hline 124 & EPEF 2008 - 20 & O USO DE ANALOGIAS NO PROCESSO COMUNICATIVO DE SALA DE AULA & Fernanda C. Bozelli, Roberto Nardi \\
\hline 125 & EPEF 2008 - 21 & $\begin{array}{l}\text { PERCEPCÃO DOS ALUNOS SOBRE A INCORPORACÃO DE ELEMENTOS DE FÍSICA MODERNA E CONTEMPORÂNEA EM UMA } \\
\text { DISCIPLINA INTRODUTÓRIA DO CURSO DE FÍSICA }\end{array}$ & Ana A. Diniz, Ruy C. M. C. Ferraz, Alice Helena C. Pierson \\
\hline 126 & EPEF 2008 - 22 & PROFESSORES DE FÍSICA E A REELABORAÇÃO DA PRÁTICA & Rebeca Vilas Boas Cardoso de Oliveira, Yassuko Hosoume \\
\hline 127 & EPEF $2008-23$ & REFLEXOS DO REGIME DE TUTORIA NA CAPACITAÇÃO DE ESTAGIÁRIOS PARA ATIVIDADES DOCENTES & Andréia Aurélio da Silva, Eduardo Adolfo Terrazzan \\
\hline 128 & EPEF 2008 - 24 & $\begin{array}{l}\text { UM ESTUDO DE CASO RELACIONANDO FORMAÇ̃̃O DE PROFESSORES, MODELAGEM MATEMÁTICA E RESOLUCCÃO DE } \\
\text { PROBLEMAS NO ENSINO DE FÍSICA }\end{array}$ & Cláudia de Oliveira Lozada, Nadja S. Magalhães \\
\hline 129 & EPEF $2008-25$ & $\begin{array}{l}\text { DIFERENÇAS E SEMELHANÇAS ENTRE ELETRICIDADE E MAGNETISMO: O DIÁLOGO HISTÓRICO ENTRE O ERRO E A } \\
\text { VERDADE SUBSIDIANDO O ENSINO DE FÍSICA }\end{array}$ & $\begin{array}{l}\text { Moacir Pereira de Souza Filho, Sérgio Luiz Bragatto Boss, } \\
\text { João José Caluzi }\end{array}$ \\
\hline 130 & EPEF 2008 - 26 & HISTÓRIA DA CIÊNCIA E APRENDIZAGEM SIGNIFICATIVA: O CONCEITO DE CARGA ELÉTRICA & $\begin{array}{l}\text { Sérgio Luiz Bragatto Boss, Moacir Pereira de Souza Filho, } \\
\text { Paulo Noronha } \\
\text { Lichon Eilhn }\end{array}$ \\
\hline 131 & EPEF 2008 - 27 & O EXPERIMENTO DE STERN-GERLACH E O SPIN DO ELÉTRON: UM EXEMPLO DE QUASI-HISTÓRIA & Gerson G. Gomes, Maurício Pietrocola \\
\hline 132 & EPEF $2008-28$ & UMA ABORDAGEM HISTÓRICA PARA O ENSINO DO CONCEITO DE POTENCIAL VETOR & Aldo Gomes Pereira, Cibelle Celestino Silva \\
\hline 133 & EPEF 2008 - 29 & $\begin{array}{l}\text { POSIÇÕES DE LICENCIANDOS EM FÍSICA SOBRE LEITURAS NO ENSINO MÉDIO DA FÍSICA MODERNA E CONTEMPORÂNEA } \\
\text { EM TEXTOS DE DIVULGAÇÃO CIENTIÍFICA }\end{array}$ & $\begin{array}{l}\text { Ricardo Henrique Almeida Dias e Maria José Pereira } \\
\text { Monteiro de Almeida }\end{array}$ \\
\hline
\end{tabular}




\begin{tabular}{|c|c|c|c|}
\hline 134 & EPEF $2008-30$ & $\begin{array}{l}\text { A INVESTIGAÇÃO DA MODELAGEM COMPUTACIONAL QUALITATIVA NA CONSTRUÇÃO DE MODELOS ATRAVÉS DO } \\
\text { AMBIENTE MODELAB }\end{array}$ & Thiéberson Gomes, Laércio Ferracioli, Rodrigo Marques \\
\hline 135 & EPEF $2008-31$ & APRENDIZAGEM ATIVA EM ÓPTICA GEOMÉTRICA: DESENVOLVIMENTO DE INSTRUMENTOS INVESTIGATIVOS & $\begin{array}{l}\text { Edson Valentim Roberto, Gláucia Grüninger Gomes Costa, } \\
\text { Tomaz Catunda }\end{array}$ \\
\hline 136 & EPEF $2008-32$ & INVESTIGACÃO DAS DIFICULDADES CONCEITUAIS DOS ESTUDANTES SOBRE CIRCUITOS ELÉTRICOS & Gláucia Grüninger Gomes Costa, Tomaz Catunda \\
\hline 137 & EPEF $2008-33$ & ABORDAGEM CTS NO ENSINO DE FÍSICA NA CONCEPÇÃO DE FUTUROS EDUCADORES & Daniela Fiorini da Silva, Maria Lúcia Vital dos Santos Abi \\
\hline 138 & EPEF $2008-34$ & $\begin{array}{l}\text { FORMAÇÃO DE PROFESSORES DE FíSICA E IMPLICAÇ̃̃ES DA RELAÇÃO CIÊNCIA, TECNOLOGIA, SOCIEDADE E AMBIENTE: } \\
\text { POSSIBILIDADES, DESAFIOS E LIMITAÇÕES }\end{array}$ & $\begin{array}{l}\text { João Amadeus Pereira Alves, Rejane Aurora Mion, } \\
\text { Washington Luiz Pacheco } \\
\text { do }\end{array}$ \\
\hline 139 & EPEF $2008-35$ & $\begin{array}{l}\text { PROFESSORES DE FÍSICA EM FORMAÇÃO INICIAL: O ENSINO DE FÍSICA, A TEMÁTICA AMBIENTAL E OS TEMAS } \\
\text { CONTROVERSOS }\end{array}$ & Luciano Fernandes Silva, Luiz Marcelo de Carvalho \\
\hline 140 & EPEF $2008-36$ & QUESTÕES SOCIO-POLÍTICAS DE CIÊNCIA ATRAVÉS DA FICCC̃̃O CIENTÍFICA: UM EXEMPLO COM “CONTATO” & Luís Paulo Piassi, Maurício Pietrocola \\
\hline 141 & EPEF $2008-37$ & A COMPREENSÃO DE LICENCIADOS EM FÍSICA SOBRE MODELOS E MODELIZAÇÃO & Juliana Machado \\
\hline 142 & EPEF $2008-38$ & A FORMAÇÃO DE PROFESSORES NAS ATAS DO ENPEC: UMA ANÁLISE PRELIMINAR & $\begin{array}{l}\text { lône Inês Pinsson Slongo, Nadir Castilho Delizoicov, Jéssica } \\
\text { Menezes Rosset }\end{array}$ \\
\hline 143 & ENPEC 2009 - 1 & $\begin{array}{l}\text { A TEMÁTICA AMBIENTAL E O ENSINO DE FÍSICA: AS DIFERENTES COMPREENSÕES DOS PROFESSORES DE FÍSICA EM } \\
\text { FORMAÇÃO INICIAL }\end{array}$ & Luciano Fernandes Silva, Luiz Marcelo de Carvalho \\
\hline 144 & ENPEC 2009 - 2 & AÇÃO DIALÓGICA E COMUNICATIVA: A FORMAÇÃO DE PROFESSORES DE FÍSICA SOB A PERSPECTIVA DAS NEGOCIAÇÕES & $\begin{array}{l}\text { Noemi Sutil, Adriana Bortoletto, Lizete Maria Orquiza de } \\
\text { Carvalho }\end{array}$ \\
\hline 145 & ENPEC 2009 - 3 & ANÁLISE DE DISCURSO DO PROJETO POLÍTICO PEDAGÓGICO DE UM CURSO DE LICENCIATURA EM FÍSICA & Laércia Maria Bertulino de Medeiros, Eliane de Moura Silva \\
\hline 146 & ENPEC $2009-4$ & EPISTEMOLOGIA NA EDUCACCÃO CIENTÍFICA: UM CAMINHO PARA DISCUTIR A CIÊNCIA EM SALA DE AULA? & Washington Raposo, Andréia Guerra \\
\hline 147 & ENPEC 2009 - 5 & CONCEPÇÕES DE PROFESSORES SOBRE ASPECTOS DA NATUREZA DA CIÊNCIA & $\begin{array}{l}\text { Elisangela Matias Miranda1, Ariane Lourenço Baffa, Denise } \\
\text { de Freitas, Alice Helena Campos Pierson }\end{array}$ \\
\hline 148 & ENPEC $2009-6$ & CONCEPCCÕES SOBRE INTERDISCIPLINARIDADE DE LICENCIANDOS EM BIOLOGIA E FÍSICA & $\begin{array}{l}\text { Rodrigo Claudino Diogo, Elisangela Matias Miranda, Denise } \\
\text { de Freitas, Alice Helena Campos Pierson }\end{array}$ \\
\hline 149 & ENPEC 2009 - 7 & $\begin{array}{l}\text { CONTRIBUIÇÕES DA ANÁLISE DE DISCURSO PARA A COMPREENSÃO DE TEXTOS PRODUZIDOS POR LICENCIANDOS EM } \\
\text { FÍSICA }\end{array}$ & $\begin{array}{l}\text { Thirza Pavan Sorpreso, Maria José P. M. de Almeida, } \\
\text { Lendro Londero da Silva }\end{array}$ \\
\hline 150 & ENPEC $2009-8$ & $\begin{array}{l}\text { CONVERSAÇÕES ENTRE AS CIÊNCIAS HUMANAS E SOCIAIS E AS CIÊNCIAS DA NATUREZA: UM ENSAIO SOBRE A PRÁXIS } \\
\text { DOCENTE EM CURSOS DE LICENCIATURA EM FÍSICA, QUIIMICA E MATEMÁTICA }\end{array}$ & Alexandre Maia do Bomfim, Rodrigo Siqueira-Batista \\
\hline
\end{tabular}




\begin{tabular}{|c|c|c|c|}
\hline 151 & ENPEC $2009-9$ & $\begin{array}{l}\text { CRENCCAS EPISTEMOLÓGICAS A RESPEITO DAS CIÊNCIAS NATURAIS E HUMANAS NO DISCURSO DE ESTUDANTES } \\
\text { UNIVERSITÁRIOS }\end{array}$ & $\begin{array}{l}\text { Isabella Oliveira,Silvania Sousa do Nascimento, Flavia } \\
\text { Rezende }\end{array}$ \\
\hline 152 & ENPEC $2009-10$ & DISCUSSÃO DAS RELAÇÕES ENTRE MATEMÁTICA E FÍSICA NO ENSINO DE RELATIVIDADE RESTRITA: UM ESTUDO DE CASO & Ricardo Karam, Maurício Pietrocola \\
\hline 153 & ENPEC 2009 - 11 & $\begin{array}{l}\text { DISCUTINDO A NATUREZA DA CIÊNCIA A PARTIR DE EPISÓDIOS DA HISTÓRIA DA COSMOLOGIA: O UNIVERSO TEVE UM } \\
\text { COMEÇO OU SEMPRE EXISTIU? }\end{array}$ & Alexandre Bagdonas Henrique, Cibelle Silva \\
\hline 154 & ENPEC $2009-12$ & ESTRATÉGIAS USADAS POR UM PROFESSOR DE ENSINO SUPERIOR PARA ENGAJAR OS ESTUDANTES NAS AULAS & Ana Luiza de Quadros, Eduardo Fleury Mortimer \\
\hline 155 & ENPEC 2009 - 13 & $\begin{array}{l}\text { FONTES PRIMÁRIAS E APRENDIZAGEM SIGNIFICATIVA:AQUISIÇÃO DE SUBSUNÇORES PARA A APRENDIZAGEM } \\
\text { DOCONCEITO DE CARGA ELÉTRICA }\end{array}$ & $\begin{array}{l}\text { Sergio Luiz Bragatto Boss, Moacir Pereira de Souza Filho, } \\
\text { João José Caluzi }\end{array}$ \\
\hline 156 & ENPEC 2009 - 14 & FORMAÇÃO DE PROFESSORES DE CIÊNCIAS: REVISÃO DE PERIÓDICOS (2006-2007) & Ana Paula Souto Silva \\
\hline 157 & ENPEC 2009 - 15 & HISTÓRIA DA CIÊNCIA E APRENDIZAGEM SIGNIFICATIVA: O EXPERIMENTO DE COULOMB & $\begin{array}{l}\text { Sergio Luiz Bragatto Boss, Moacir Pereira de Souza Filho, } \\
\text { João José Caluzi }\end{array}$ \\
\hline 158 & ENPEC 2009 - 16 & HISTÓRIA E FILOSOFIA DA CIÊNCIA NOS CURRICULOS DOS CURSOS DE LICENCIATURA EM FÍSICA E QUÍMICA DA UFRN & $\begin{array}{l}\text { Giulliano José Segundo Alves Pereira, André Ferrer P. } \\
\text { Martins }\end{array}$ \\
\hline 159 & ENPEC 2009 - 17 & $\begin{array}{l}\text { INTERDISCIPLINARIDADE NA FORMACCÃO DE PROFESSORES DE CIÊNCIAS NATURAIS E MATEMÁTICA: ALGUMAS } \\
\text { REFLEXÕES }\end{array}$ & $\begin{array}{l}\text { Roseli Adriana Blümke Feistel, Sylvia Regina Pedrosa } \\
\text { Maestrelli }\end{array}$ \\
\hline 160 & ENPEC 2009 - 18 & $\begin{array}{l}\text { O DISCURSO EM SALA DE AULA GERENCIADO POR UM PROFESSOR ESTAGIÁRIO: UM INSTRUMENTO PARA A FORMAÇÃO } \\
\text { DE PROFESSORES DE FíSICA }\end{array}$ & Rodrigo Drumond Vieira, Silvania Sousa do Nascimento \\
\hline 161 & ENPEC 2009 - 19 & $\begin{array}{l}\text { O PROCESSO DE PLANEJAMENTO PARA IMPLANTAÇÃO DE UM PROJETO POLÍTICO PEDAGÓGICO DE UMA LICENCIATURA } \\
\text { EM FISICA: ANÁLISES PRELIMINARES }\end{array}$ & Beatriz Salemme Corrêa Cortela, Roberto Nardi \\
\hline 162 & ENPEC $2009-20$ & $\begin{array}{l}\text { PERCEPČ̃̃O DE PROFESSORES UNIVERSITÁRIOS DE CIÊNCIAS SOBRE OS PROCESSOS ENVOLVIDOS EM SUA } \\
\text { CONSTITUIÇÃO: UMA ABORDAGEM FREIRIANA }\end{array}$ & Welton Yudi Oda \\
\hline 163 & ENPEC $2009-21$ & PERSPECTIVAS PARA ALÉM DA RACIONALIDADE TÉCNICA NA FORMAÇÃO DE PROFESSORES DAS CIÊNCIAS & $\begin{array}{l}\text { Márcia Sampaio Duarte, Luziane Beyruth Schwartz, Alcina } \\
\text { M. T. Braz da Silva, Flavia Rezende }\end{array}$ \\
\hline 164 & ENPEC 2009 - 22 & $\begin{array}{l}\text { PRODUCCÃO CIENTíFICA SOBRE FORMAÇÃO DE PROFESSORES DE CIÊNCIAS EM EVENTOS CIENTÍFICOS NA ÁREA DE } \\
\text { EDUCAÇÃO: PRIMEIRAS REVELAÇÕES }\end{array}$ & 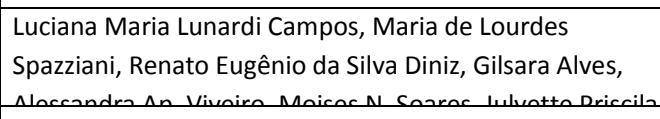 \\
\hline 165 & ENPEC $2009-23$ & $\begin{array}{l}\text { PROFESSORES ARTISTAS-REFLEXIVOS: O TRABALHO DOCENTE BASEADO NUMA ASSOCIAÇ̃̃O DE COMPANHEIROS DE } \\
\underline{\text { OFÍCIO }}\end{array}$ & Raphael Alves Feitosa, Raquel Crosara Maia Leite \\
\hline 166 & ENPEC 2009 - 24 & $\begin{array}{l}\text { REFLEXÃO E DESENVOLVIMENTO DO CONHECIMENTO PEDAGÓGICO DO CONTEÚDO: DE LICENCIANDO A PROFESSOR DE } \\
\text { QUÍMICA }\end{array}$ & Gildo Girotto Júnior, Carmen Fernandez \\
\hline 167 & ENPEC 2009 - 25 & $\begin{array}{l}\text { REFLEXÃO SOBRE A INTERDEPENDÊNCIA DOS PROCESSOS DE ENSINO-APRENDIZAGEM E AVALIACCÃO DA APRENDIZAGEM } \\
\text { DE ALUNOS INGRESSANTES DE CURSO DE FÍSICA }\end{array}$ & $\begin{array}{l}\text { Sayonara Salvador Cabral da Costa, Maria Eulália Pinto } \\
\text { Tarragó, Leonardo Santos }\end{array}$ \\
\hline
\end{tabular}




\begin{tabular}{|c|c|c|c|}
\hline 168 & ENPEC 2009 - 26 & REFLEXÕES SOBRE A BAIXA PROCURA PELO CURSO DE FÍSICA NAS UNIVERSIDADES FEDERAIS DE PERNAMBUCO & Micaías Andrade Rodrigues, Francimar Martins Teixeira \\
\hline 169 & ENPEC 2009 - 27 & $\begin{array}{l}\text { UMA ANÁLISE AXIOLÓGICA NA PERSPECTIVA DA EDUCAÇÃO CIENTÍFICA: APROXIMAÇÃO DOS VALORES COGNITIVOS } \\
\text { COM A FORMAÇÃO DOCENTE }\end{array}$ & Rosana Figueiredo Salvi, Irinéa de Lourdes Batista \\
\hline 170 & ENPEC 2009 - 28 & $\begin{array}{l}\text { UMA ANÁLISE DOS PROBLEMAS DE PESQUISA SOBRE FORMAÇÃO INICIAL DE PROFESSORES NOS ARTIGOS DAS REVISTAS } \\
\text { ENSAIO E REVISTA BRASILEIRA DE PESQUISA EM EDUCAÇÃO EM CIÊNCIAS (1999-2007) }\end{array}$ & $\begin{array}{l}\text { Angela Meneghello Passos, Marinez Meneghello Passos, } \\
\text { Sergio de Mello Arruda }\end{array}$ \\
\hline 171 & ENPEC $2009-29$ & $\begin{array}{l}\text { UMA COMUNIDADE VIRTUAL DE PRÁTICA COMO MEIO DE DIMINUIR A LACUNA PESQUISA-PRÁTICA NA EDUCAÇÃO } \\
\text { CIENTÍFICA }\end{array}$ & Charbel Niño El-Hani, Ileana Greca \\
\hline
\end{tabular}




\begin{tabular}{|c|c|c|}
\hline Perfil 1 & $\begin{array}{l}\text { Trabalho sem núcleo/foco na formação de } \\
\text { professores, voltados para a física quanto a } \\
\text { formação do licenciando, sem explicitação de } \\
\text { concepção de professor }\end{array}$ & $\begin{array}{l}1,10,11,15,24,28,31,32,33,34,35,36,39,40,41 \\
42,50,56,78,79,85,88,89,90,100,101,102,107 \\
110,111,129,130,131,132,136,152,155,157,1 \\
67\end{array}$ \\
\hline Perfil 2 & $\begin{array}{l}\text { Trabalho sem núcleo/foco na formação de } \\
\text { professores, voltados para o núcleo pedagógico } \\
\text { quanto a formação do licenciando, sem } \\
\text { explicitação de concepção de professor }\end{array}$ & $30,106,134,151$ \\
\hline Perfil 3 & $\begin{array}{l}\text { Trabalho com núcleo/foco na formação de } \\
\text { professores, voltados para o núcleo pedagógico } \\
\text { quanto a formação do licenciando, sem } \\
\text { explicitação de concepção de professor }\end{array}$ & $\begin{array}{l}8,12,22,23,64,65,71,81,92,105,108,114,115,1 \\
16,140,143,170\end{array}$ \\
\hline Perfil 4 & $\begin{array}{l}\text { Trabalho com núcleo/foco na formação de } \\
\text { professores, voltados para o núcleo pedagógico } \\
\text { quanto a formação do licenciando, com } \\
\text { explicitação de concepção de professor }\end{array}$ & $\begin{array}{l}3,6,7,13,16,20,21,25,26,27,29,37,43,46,47,48 \\
, 49,51,52,53,54,55,60,61,62,63,66,67,68,70,7 \\
2,75,76,77,82,84,86,93,94,95,99,112,117,118 \\
, 121,123,124,127,133,135,137,138,139,142,1 \\
44,147,148,149, \\
, 154,156,160,164,165,166,171\end{array}$ \\
\hline Perfil 5 & $\begin{array}{l}\text { Trabalho com núcleo/foco na formação de } \\
\text { professores, voltados para o núcleo física } \\
\text { quanto a formação do licenciando, com } \\
\text { explicitação de concepção de professor }\end{array}$ & $5,57,158$ \\
\hline Perfil 6 & $\begin{array}{l}\text { Trabalho com núcleo/foco na formação de } \\
\text { professores, voltados para a física quanto a } \\
\text { formação do licenciando, sem explicitação de } \\
\text { concepção de professor }\end{array}$ & $\begin{array}{l}2,4,9,58,59,69,80,87,91,96,103,104,109,113 \\
125,128,141,146,153\end{array}$ \\
\hline Perfil 7 & Pertencentes ao Núcleo Físico e Pedagógico & $\begin{array}{l}14,17,18,19,38,44,45,73,74,83,97,98,119,120 \\
122,126,145,159,161,162,163,168,169\end{array}$ \\
\hline
\end{tabular}




\section{Anexo C - \\ Roteiro de Entrevista}

Começo: Explicação que a investigação é sobre um aspecto apresentado pelas diretrizes, que trata da importância da articulação entre conhecimento especifico e conhecimento pedagógico. Estamos investigando como isso está sendo tratado nos cursos de licenciatura.

- Como você vê a questão da articulação nos saberes de física e dos saberes pedagógicos em um curso de licenciatura em física? O parecer a coloca como central... Você considera realmente central? Haveria outras questões mais ou igualmente relevantes a serem superadas?

- Que disciplinas você ministra no curso atualmente? Quais já ministrou com mais freqüência? Quais disciplinas são de sua preferência ministrar?

- Dentro das diretrizes, há uma grande ênfase para que na formação possa ser trabalhado tanto a formação em física com a formação para ser professor de Física. Isso é para acontecer na mesma disciplina/momento, ou em disciplinas/momentos diferentes? Por exemplo, nas disciplinas que você ministra, é possível isso, ou você tem experiências nesse sentido? Como você reconhece/lida com a questão dessa dicotomia na sua prática como professor?

-- O CEFET tem uma estrutura muito distinta dos outros tipos de instituições que fazem formação de professores, as universidades... Essas diferenças estruturais da instituição refletem no curso de alguma maneira? Isso é bom? É ruim? E em relação a questão da dicotomia?

- No CEFET, há apoio para a formação de professores dessa maneira?

- Você acha que o curso está formando bons professores de Física?

- Você acha que os alunos daqui saem sabendo bem física? Mais ou menos que nos cursos mais "tradicionais", quer dizer, onde a estrutura da licenciatura é mais próxima do Bacharelado?

- Gostaria de saber um pouco da sua trajetória profissional e de vida que lha trouxe a trabalhar no CEFET/SP e com formação de professores...

- O objetivo sempre foi trabalhar com formação de formação de professores ou não? Trabalhar no CEFET, com a licenciatura, é um emprego como qualquer outro?

- Eu quero entender porque alguns professores aderem à proposta e a compreendem, enquanto outros a ignoram ou se mostram refratários. Você teria alguma ideia de porque isso ocorre? 


\begin{tabular}{|c|c|c|c|c|c|c|c|c|c|c|c|c|}
\hline \multirow[b]{2}{*}{ 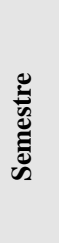 } & \multirow[b]{2}{*}{ Espaço curricular } & \multirow[b]{2}{*}{ 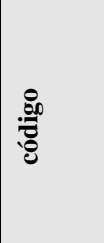 } & \multicolumn{5}{|c|}{ Discriminação da carga horária } & \multicolumn{5}{|c|}{ Competências afins } \\
\hline & & & 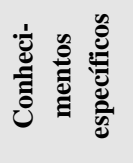 & 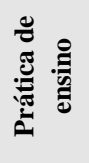 & 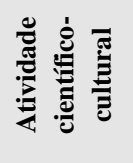 & 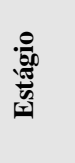 & 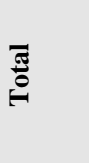 & - & a & m & $\sigma$ & in \\
\hline \multirow{5}{*}{$1^{\mathrm{o}}$} & Matemática aplicada à ciência-I & MTP & 60 & & 15 & & 75 & & & $\mathrm{x}$ & $\mathrm{x}$ & \\
\hline & Introdução à ciência experimental & CEP & 60 & 15 & & & 75 & & & $\mathrm{x}$ & $\mathrm{x}$ & \\
\hline & Comunicação e linguagem & $\mathrm{COE}$ & 60 & 15 & & & 75 & $\mathrm{x}$ & $\mathrm{x}$ & & & $\mathrm{x}$ \\
\hline & Introdução à mecânica clássica & MCS & 60 & & 15 & & 75 & & & $\mathrm{x}$ & & \\
\hline & Fundamentos da educação & FED & 45 & 15 & 15 & & 75 & $\mathrm{x}$ & $\mathrm{x}$ & & $\mathrm{x}$ & $\mathrm{x}$ \\
\hline \multirow{5}{*}{$2^{\mathrm{O}}$} & Matemática aplicada à ciência-II & MM2 & 60 & & 15 & & 75 & & & $\mathrm{x}$ & $\mathrm{x}$ & \\
\hline & Mecânica aplicada & MEP & 60 & 15 & & & 75 & & & $\mathrm{x}$ & $\mathrm{x}$ & \\
\hline & Gravitação e leis de conservação & GLC & 60 & 15 & & & 75 & & & $\mathrm{x}$ & $\mathrm{x}$ & \\
\hline & Mecânica dos sólidos e fluidos & MCF & 60 & 15 & & & 75 & & & $\mathrm{x}$ & $\mathrm{x}$ & \\
\hline & Introdução ao ensino e divulgação da ciência & EDC & 30 & 30 & 15 & & 75 & & $\mathrm{x}$ & $\mathrm{x}$ & & \\
\hline \multirow{5}{*}{$3^{0}$} & Matemática aplicada à ciência-III & MM3 & 75 & & & & 75 & & & $\mathrm{x}$ & $\mathrm{x}$ & \\
\hline & Eletricidade e circuitos elétricos & ECE & 75 & & & & 75 & & & $\mathrm{x}$ & $\mathrm{x}$ & \\
\hline & Fenômenos ondulatórios & FEO & 60 & 15 & & & 75 & & & $\mathrm{x}$ & $\mathrm{x}$ & \\
\hline & Termodinâmica & TMD & 60 & 15 & & & 75 & & & $\mathrm{x}$ & $\mathrm{x}$ & \\
\hline & Estatística aplicada à ciência e à educação & EAC & 60 & 15 & & & 75 & & & $\mathrm{x}$ & $\mathrm{x}$ & $\mathrm{x}$ \\
\hline \multirow{5}{*}{$4^{\mathrm{O}}$} & Matemática aplicada à ciência-IV & MM4 & 75 & & & & 75 & & & $\mathrm{x}$ & $\mathrm{x}$ & \\
\hline & Fundamentos do eletromagnetismo & FEM & 75 & & & & 75 & & & $\mathrm{x}$ & $\mathrm{x}$ & \\
\hline & Cultura políitica e formação de professores & $\mathrm{HCP}$ & 45 & 30 & & & 75 & $\mathrm{x}$ & $\mathrm{x}$ & & & \\
\hline & Óptica & OTC & 60 & 15 & & & 75 & & & $\mathrm{x}$ & $\mathrm{x}$ & \\
\hline & Epistemologia e ensino da ciência & FEC & 45 & 15 & 15 & & 75 & & & $\mathrm{x}$ & & $\mathrm{X}$ \\
\hline \multirow{5}{*}{$5^{\circ}$} & Política e estrutura do ensino no Brasil & PEE & 30 & 15 & & 30 & 75 & $\mathrm{X}$ & $\mathrm{x}$ & & & \\
\hline & Estrutura da matéria & ESM & 60 & & 15 & & 75 & & & $\mathrm{x}$ & $\mathrm{x}$ & \\
\hline & Física e ciências da vida & FCV & 60 & 15 & & & 75 & & & $\mathrm{x}$ & $\mathrm{x}$ & \\
\hline & Introdução à física moderna & FMO & 60 & 15 & & & 75 & & & $\mathrm{x}$ & $\mathrm{x}$ & \\
\hline & Oficina de projetos de ensino - I & PE1 & 30 & & 15 & 30 & 75 & & & $\mathrm{x}$ & $\mathrm{x}$ & $\mathrm{x}$ \\
\hline \multirow{5}{*}{$6^{\circ}$} & Física e Química & FIQ & 60 & 15 & & & 75 & & & $\mathrm{x}$ & $\mathrm{x}$ & \\
\hline & Física atômica e molecular & FAM & 60 & & 15 & & 75 & & & $\mathrm{x}$ & $\mathrm{x}$ & \\
\hline & Ciência, história e cultura & CHC & 45 & 30 & & & 75 & $\mathrm{x}$ & & $\mathrm{x}$ & & \\
\hline & Escola e sociedade & ESS & 30 & & & 45 & 75 & $\mathrm{x}$ & $\mathrm{x}$ & & $\mathrm{x}$ & $\mathrm{x}$ \\
\hline & Oficina de projetos de ensino- II & PE2 & 30 & & 15 & 30 & 75 & & & $\mathrm{x}$ & $\mathrm{x}$ & $\mathrm{x}$ \\
\hline \multirow{4}{*}{$7^{\circ}$} & Física nuclear e de partículas & FNP & 60 & 15 & & & 75 & & & $\mathrm{x}$ & $\mathrm{x}$ & \\
\hline & \begin{tabular}{|l} 
Física do estado sólido \\
\end{tabular} & FES & 60 & 15 & & & 75 & & & $\mathrm{x}$ & $\mathrm{x}$ & \\
\hline & Educação científica e prática de ensino - I & CI1 & 15 & 30 & & 105 & 150 & $\mathrm{x}$ & $\mathrm{x}$ & $\mathrm{x}$ & $\mathrm{x}$ & $\mathrm{x}$ \\
\hline & Oficina de projetos de ensino- III & PE3 & 30 & & 15 & 30 & 75 & & & $\mathrm{x}$ & $\mathrm{x}$ & $\mathrm{x}$ \\
\hline \multirow{4}{*}{$8^{\circ}$} & Física e ciências da Terra & FCT & 60 & & 15 & & 75 & & & $\mathrm{x}$ & $\mathrm{x}$ & \\
\hline & Astronomia & AST & 60 & & 15 & & 75 & & & $\mathrm{x}$ & $\mathrm{x}$ & \\
\hline & Educação científica e prática de ensino - II & $\mathrm{Cl} 2$ & 15 & 30 & & 105 & 150 & $\mathrm{X}$ & $\mathrm{x}$ & $\mathrm{X}$ & $\mathrm{x}$ & $\mathrm{X}$ \\
\hline & Oficina de projetos de ensino-IV & PE4 & 30 & & 15 & 30 & 75 & & & $\mathrm{x}$ & $\mathrm{x}$ & $\mathrm{x}$ \\
\hline \multicolumn{2}{|c|}{ Total acumulado (em horas) } & & 1980 & 405 & 210 & 405 & 3000 & & & & & \\
\hline
\end{tabular}




\section{Espaços Curriculares, Competências e eixos articuladores do curso do IFSP}

Competência (1): Concepção e promoção de práticas educativas compatíveis com os princípios da sociedade democrática, a difusão e aprimoramento de valores éticos, o respeito e estímulo à diversidade cultural e a educação para a inteligência crítica.

Descrição: A capacidade do professor de perceber-se e situar-se como sujeito histórico e político bem como aos seus alunos e, em conseqüência, desenvolver uma ação pedagógica que articule e promova os valores que fundamentam a vida democrática é uma competência indispensável para o trabalho do profissional em educação. As escolhas metodológicas e didáticas devem observar a diversidade social, cultural e intelectual dos alunos e contribuir para a justificação e aprimoramento do papel social da escola.

Competência (2): Compreensão da inserção da escola na realidade social e cultural contemporânea e das práticas de gestão do processo educativo voltadas à formação e consolidação da cidadania.

Descriçãa: A atuação do professor deve objetivar a inclusão social dos alunos por intermédio de uma prática docente contextualizada na realidade social em que a escola está inserida. É indispensável a compreensão das especificidades e contornos da relação entre educação e cultura, de modo a conduzir práticas educativas condizentes com a realidade e as possibilidades concretas da educação no processo da transformação social visando o bem estar coletivo.

Competência (3): Domínio de conteúdos disciplinares específicos, da articulação interdisciplinar, multidisciplinar e transdiciplinar dos mesmos, tendo em vista a natureza histórica e social da construção do conhecimento e sua relevância para a compreensão do mundo contemporâneo.

Descrição: O professor deve contribuir, mediante atitudes pessoais e práticas profissionais concretas, para que seus alunos desenvolvam a capacidade de compreensão da importância do conhecimento no desenvolvimento das sociedades humanas e na elaboração de visões alternativas da realidade, mediante a reflexão teórica e a mobilização de conteúdos específicos do saber. A abordagem dos conteúdos disciplinares deve sempre priorizar uma visão erudita (no sentido de saber aprofundado), culturalmente rica e humanizada do conhecimento, de modo a favorecer, no aluno, uma atitude crítica e construtiva frente ao saber e uma apreensão da sua importância para o aprimoramento da qualidade de vida material e espiritual do homem.

Competência (4): Condução da atividade docente a partir do domínio de conteúdos pedagógicos aplicados às áreas e disciplinas específicas a serem ensinadas, da sua articulação com temáticas afins e do monitoramento e avaliação do processo ensino-aprendizagem.

Descriçãa: A atuação do professor baseia-se fortemente na sua capacidade de promover uma avaliação eficaz e crítica de sua rotina profissional e de reagir prontamente aos acontecimentos inéditos e desafiadores que ela comporta. A experiência cotidiana deve ser refletida e articulada aos conhecimentos teóricos, de modo a balizar a formulação e reformulação das práticas. A habilidade em gerir e organizar trabalhos coletivos, a criatividade e versatilidade na elaboração de estratégias e dinâmicas voltadas ao aprimoramento do ensino são habilidades indispensáveis ao professor.

Competência (5): Capacidade de auto-avaliação e gerenciamento do aprimoramento profissional e domínio dos processos de investigação necessários ao aperfeiçoamento da prática pedagógica.

Descrição: A capacidade de gerenciar processos metacognitivos, a flexibilidade para a autocrítica, para adaptar-se, para mudanças pessoais, o aprimoramento da auto-percepção e da alteridade, a ousadia intelectual, a capacidade de síntese e análise, a sensibilidade estética, a desenvoltura pessoal e o gosto pela cultura compõem um quadro de competências que fundamentam o trabalho do profissional em educação. 


\section{Os seis eixos articuladores das diretrizes curriculares para a formação de professores no projeto da Licenciatura em Física do CEFETSP:}

O parecer CNE/CP 09/2001 especifica os critérios de organização que completam as orientações para desenhar uma matriz curricular coerente para a formação do professor da educação básica, em eixos em torno dos quais se articulam dimensões que precisam ser contempladas na formação profissional docente e sinalizam o tipo de atividades de ensino e aprendizagem que materializam o planejamento e a ação dos formadores de formadores, que também são contemplados no nosso projeto pedagógico.

\subsubsection{Eixo articulador dos diferentes âmbitos de conhecimento profissional}

Foram instituídos nos espaços curriculares da Licenciatura diversificadas formas de aquisição de conhecimento e de expressão dos mesmos a fim de preparar adequadamente o futuro professor a trabalhar com oficinas, seminários, grupos de trabalho supervisionado, grupos de estudo, tutorias e eventos, atividades de extensão, entre outros; dando subsídios para torná-los capazes de promover atuações diferenciadas, diferentes modos de organização do trabalho, possibilitando o exercício das diferentes competências a serem desenvolvidas na educação.

\subsubsection{Eixo articulador da interação e comunicação e do desenvolvimento da autonomia intelectual e profissional}

As atividades propostas de produção coletiva nos espaços curriculares como trabalhos em grupo, seminários, produções de atividades e intervenções pedagógicas dão subsídio e para atividades de extensão como a Semana da Licenciatura destinada ao público interno do CEFET e a Caravana da Ciência, que visita escolas da periferia e do centro de São Paulo, e capacitam os futuros professores a promover atividades constantes de aprendizagem colaborativa e de interação, de comunicação entre os professores em formação, deles com educandos e também com os formadores, uma vez que tais aprendizagens necessitam de práticas sistemáticas para se efetivarem. Favorecemos assim a convivência interativa dentro da instituição e dos ambientes educacionais.

\subsubsection{Eixo articulador entre disciplinaridade e interdisciplinaridade}

O conhecimento humano atravessa as tradicionais fronteiras disciplinares, em qualquer nível de ensino que se pretenda atuar e na maioria das vezes exige um trabalho integrado de diferentes professores e profissionais. Na formação do professor isso se torna ainda mais relevante na perspectiva da simetria invertida, o que reforça a necessidade de que a matriz curricular da formação do professor contemple estudos e atividades interdisciplinares. Nossa matriz é permeada por espaços curriculares que se propõem interdisciplinares, tanto do ponto de vista do debate teórico sobre a interdisciplinaridade, nos fundamentos da educação, como do ponto de vista da ação pedagógica interdisciplinar nas inter-relações do ensino da física com a literatura, geografia, história, filosofia, matemática, química, biologia, astronomia etc., possibilitando ao futuro professor estabelecer diálogos com múltiplos interlocutores nos diversos ambientes de trabalho que possa atuar e principalmente na escola.

\subsubsection{O eixo que articula a formação comum e a formação específica}


A articulação entre as competências comuns aos professores da educação básica e às especificidades do trabalho educativo com diferentes etapas da escolaridade e diferentes faixas etárias de alunos nas instituições que os futuros professores irão atuar, deve contemplá-las de modo integrado, mantendo o princípio de que a formação deve ter como referência a atuação profissional e que a diferença se dá, principalmente, no que se refere às particularidades das etapas em que a docência ocorre. Assim a docência deverá ser tratada no curso de modo específico, numa concepção que se contrapõe ao tratamento especial que por vezes se tenta ofertar aos alunos. A organização dos espaços curriculares da Licenciatura do CEFETSP atende prioritariamente à educação básica, com foco no ensino médio, mas inclui espaços curriculares adequados a garantir a tematização comum de questões centrais da educação e da aprendizagem às diversas faixas etárias, a sistematização sólida e consistente de conhecimento sobre objetos de ensino numa construção de perspectiva interdisciplinar, incluindo opções para atuação em modalidades ou campos específicos do ensino como a educação jovens e adultos e a educação especial nos espaços curriculares de oficinas de projetos de ensino. No ano de 2004 ofertamos oficinas na modalidade de educação especial, e em 2005 oficinas na modalidade de educação de jovens e adultos.

\subsubsection{Eixo articulador dos conhecimentos a serem ensinados e dos conhecimentos educacionais e pedagógicos que fundamentam a ação educativa.}

A proposta das diretrizes é clara quanto à superação do padrão segundo o qual os conhecimentos práticos e pedagógicos são responsabilidade dos pedagogos enquanto os conhecimento específicos a serem ensinados são responsabilidade dos especialistas por área de conhecimento. Propomos como paradigma para essa superação a ação integrada em cada espaço curricular entre conhecimentos pedagógicos e conhecimentos específicos no âmbito do ensino de física. A equipe de formadores deve garantir a ampliação, ressignificação e equilíbrio de conteúdos com dupla direção no que se refere aos conteúdos pedagógicos e educacionais.

\subsubsection{Eixo articulador das dimensões teóricas e práticas}

A prática na matriz curricular não pode ficar reduzida a um espaço isolado, que a reduza ao estágio como algo fechado em si mesmo e desarticulado do restante do curso é necessário que o futuro professor tenha a oportunidade de participar de uma reflexão coletiva e sistemática sobre esse processo. Assim adotamos como princípio que os estágios em cada espaço curricular estão inseridos num contexto teórico próprio e esse contexto é que direciona o olhar do estagiário para a investigação da ação do profissional do professor. Os espaços curriculares específicos vinculados ao estágio supervisionado não são os únicos a integrar teoria e prática, sua especificidade está no conhecimento da ação profissional do professor e não na prática como componente curricular. É essa outra abordagem da dimensão prática que deve ser permanentemente trabalhada durante todo o curso, inserida nos espaços curriculares, tanto na perspectiva da sua aplicação no mundo social e natural quanto na perspectiva da sua didática.

As atividades de atuação coletiva e integrada dos formadores nos espaços curriculares transcendem dessa forma o estágio e têm como finalidade promover a articulação das diferentes práticas numa perspectiva interdisciplinar, com ênfase nos procedimentos de observação e reflexão para compreender e atuar em situações contextualizadas, tais como o registro de observações realizadas e a resolução de situaçõesproblema características do cotidiano profissional. 


\section{Tabela 4: Os eixos articuladores das diretrizes e os espaços curriculares do CEFETSP}

\begin{tabular}{|c|c|c|c|c|c|c|c|c|c|c|c|c|c|}
\hline \multirow{2}{*}{ 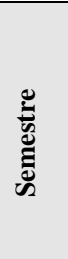 } & \multirow[b]{2}{*}{ Espaço curricular } & \multirow[b]{2}{*}{ : } & \multicolumn{5}{|c|}{ Discriminação da carga horária } & \multicolumn{6}{|c|}{$\begin{array}{l}\text { Eixos articuladores das } \\
\text { diretrizes curriculares }\end{array}$} \\
\hline & & & 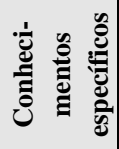 & 胥 & 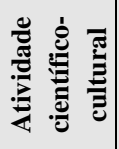 & 离 & 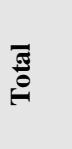 & in & in & in & $\begin{array}{l}\stackrel{7}{\min } \\
\text { in }\end{array}$ & $\begin{array}{l}n \\
\text { ing } \\
\text { ing }\end{array}$ & 常 \\
\hline \multirow{5}{*}{$1^{\mathrm{o}}$} & Matemática aplicada à ciência-I & MTP & 60 & & 15 & & 75 & $\mathrm{x}$ & $\mathrm{x}$ & $\mathrm{x}$ & & & $\mathrm{x}$ \\
\hline & Introdução à ciência experimental & CEP & 60 & 15 & & & 75 & $\mathrm{x}$ & $\mathrm{x}$ & & & & $\mathrm{x}$ \\
\hline & Comunicação e linguagem & $\mathrm{COE}$ & 60 & 15 & & & 75 & $\mathrm{x}$ & $\mathrm{x}$ & $\mathrm{x}$ & & & $\mathrm{x}$ \\
\hline & Introdução à mecânica clássica & MCS & 60 & & 15 & & 75 & $\mathrm{x}$ & $\mathrm{x}$ & & & $\mathrm{x}$ & $\mathrm{x}$ \\
\hline & Fundamentos da educação & FED & 45 & 15 & 15 & & 75 & $\mathrm{x}$ & $\mathrm{x}$ & $\mathrm{x}$ & & $\mathrm{x}$ & $\mathrm{x}$ \\
\hline \multirow{5}{*}{$2^{\mathrm{o}}$} & Matemática aplicada à ciência-II & MM2 & 60 & & 15 & & 75 & $\mathrm{x}$ & & $\mathrm{x}$ & & $\mathrm{x}$ & $\mathrm{x}$ \\
\hline & Mecânica aplicada & MEP & 60 & 15 & & & 75 & $\mathrm{x}$ & & & & & $\mathrm{x}$ \\
\hline & Gravitação e leis de conservação & GLC & 60 & 15 & & & 75 & $\mathrm{x}$ & & & & & $\mathrm{x}$ \\
\hline & Mecânica dos sólidos e fluidos & MCF & 60 & 15 & & & 75 & $\mathrm{x}$ & $\mathrm{x}$ & & & & $\mathrm{x}$ \\
\hline & Introdução ao ensino e divulgação da ciência & EDC & 30 & 30 & 15 & & 75 & $\mathrm{x}$ & $\mathrm{x}$ & $\mathrm{x}$ & & $\mathrm{x}$ & $\mathrm{x}$ \\
\hline \multirow{5}{*}{$3^{\mathrm{o}}$} & Matemática aplicada à ciência-III & MM3 & 75 & & & & 75 & $\mathrm{x}$ & & $\mathrm{x}$ & & & \\
\hline & Eletricidade e circuitos elétricos & ECE & 75 & & & & 75 & $\mathrm{x}$ & & $\mathrm{x}$ & & & \\
\hline & Fenômenos ondulatórios & FEO & 60 & 15 & & & 75 & $\mathrm{x}$ & & & & & $\mathrm{x}$ \\
\hline & Termodinâmica & TMD & 60 & 15 & & & 75 & $\mathrm{x}$ & $\mathrm{x}$ & & & & $\mathrm{x}$ \\
\hline & Estatística aplicada à ciência e à educação & EAC & 60 & 15 & & & 75 & $\mathrm{x}$ & $\mathrm{x}$ & $\mathrm{x}$ & & & $\mathrm{x}$ \\
\hline \multirow{5}{*}{$4^{\mathrm{o}}$} & Matemática aplicada à ciência-IV & MM4 & 75 & & & & 75 & $\mathrm{x}$ & & $\mathrm{x}$ & & & \\
\hline & Fundamentos do eletromagnetismo & FEM & 75 & & & & 75 & $\mathrm{x}$ & & & & $\mathrm{x}$ & \\
\hline & Cultura política e formação de professores & $\mathrm{HCP}$ & 45 & 30 & & & 75 & $\mathrm{x}$ & $\mathrm{x}$ & $\mathrm{x}$ & & & $\mathrm{x}$ \\
\hline & Óptica & OTC & 60 & 15 & & & 75 & $\mathrm{x}$ & & & & $\mathrm{x}$ & $\mathrm{x}$ \\
\hline & Epistemologia e ensino da ciência & FEC & 45 & 15 & 15 & & 75 & $\mathrm{x}$ & $\mathrm{x}$ & $\mathrm{x}$ & & $\mathrm{x}$ & $\mathrm{x}$ \\
\hline \multirow{5}{*}{$5^{\mathrm{o}}$} & Política e estrutura do ensino no Brasil & PEE & 30 & 15 & & 30 & 75 & $\mathrm{x}$ & $\mathrm{x}$ & $\mathrm{x}$ & & $\mathrm{x}$ & $\mathrm{x}$ \\
\hline & Estrutura da matéria & ESM & 60 & & 15 & & 75 & $\mathrm{x}$ & $\mathrm{x}$ & & & $\mathrm{x}$ & $\mathrm{x}$ \\
\hline & Física e ciências da vida & FCV & 60 & 15 & & & 75 & $\mathrm{x}$ & $\mathrm{x}$ & $\mathrm{x}$ & & $\mathrm{x}$ & $\mathrm{x}$ \\
\hline & Introdução à física moderna & FMO & 60 & 15 & & & 75 & $\mathrm{x}$ & & & & & $\mathrm{x}$ \\
\hline & Oficina de projetos de ensino - I & PE1 & 30 & & 15 & 30 & 75 & & $\mathrm{x}$ & $\mathrm{x}$ & $\mathrm{x}$ & $\mathrm{x}$ & $\mathrm{x}$ \\
\hline \multirow{5}{*}{$6^{\mathrm{o}}$} & Física e Química & FIQ & 60 & 15 & & & 75 & $\mathrm{x}$ & $\mathrm{x}$ & $\mathrm{x}$ & & $\mathrm{x}$ & $\mathrm{x}$ \\
\hline & Física atômica e molecular & FAM & 60 & & 15 & & 75 & $\mathrm{x}$ & & & & & $\mathrm{x}$ \\
\hline & Ciência, história e cultura & $\mathrm{CHC}$ & 45 & 30 & & & 75 & $\mathrm{x}$ & $\mathrm{x}$ & $\mathrm{x}$ & & $\mathrm{x}$ & $\mathrm{x}$ \\
\hline & Escola e sociedade & ESS & 30 & & & 45 & 75 & $\mathrm{x}$ & $\mathrm{x}$ & $\mathrm{x}$ & & $\mathrm{x}$ & $\mathrm{x}$ \\
\hline & Oficina de projetos de ensino- II & PE2 & 30 & & 15 & 30 & 75 & & $\mathrm{x}$ & $\mathrm{x}$ & $\mathrm{x}$ & $\mathrm{x}$ & $\mathrm{x}$ \\
\hline \multirow{4}{*}{$7^{0}$} & Física nuclear e de partículas & FNP & 60 & 15 & & & 75 & $\mathrm{x}$ & & & & & $\mathrm{x}$ \\
\hline & Física do estado sólido & FES & 60 & 15 & & & 75 & $\mathrm{x}$ & $\mathrm{x}$ & & & & $\mathrm{x}$ \\
\hline & Educação científica e prática de ensino - I & CI1 & 15 & 30 & & 105 & 150 & & $\mathrm{x}$ & $\mathrm{x}$ & & $\mathrm{x}$ & $\mathrm{x}$ \\
\hline & Oficina de projetos de ensino- III & PE3 & 30 & & 15 & 30 & 75 & & $\mathrm{x}$ & $\mathrm{x}$ & $\mathrm{x}$ & $\mathrm{x}$ & $\mathrm{x}$ \\
\hline \multirow{4}{*}{$8^{0}$} & Física e ciências da Terra & FCT & 60 & & 15 & & 75 & $\mathrm{x}$ & & $\mathrm{x}$ & & & $\mathrm{x}$ \\
\hline & Astronomia & AST & 60 & & 15 & & 75 & $\mathrm{x}$ & $\mathrm{x}$ & $\mathrm{x}$ & & $\mathrm{x}$ & $\mathrm{x}$ \\
\hline & Educação científica e prática de ensino - II & $\mathrm{CI} 2$ & 15 & 30 & & 105 & 150 & & $\mathrm{x}$ & $\mathrm{x}$ & & $\mathrm{x}$ & $\mathrm{x}$ \\
\hline & Oficina de projetos de ensino-IV & PE4 & 30 & & 15 & 30 & 75 & & $\mathrm{x}$ & $\mathrm{X}$ & $\mathrm{x}$ & $\mathrm{x}$ & $\mathrm{x}$ \\
\hline \multicolumn{2}{|c|}{ Total acumulado (em horas) } & & 1980 & 405 & 210 & 405 & 3000 & & & & & & \\
\hline
\end{tabular}




\section{ANEXO E \\ - Trabalhos e a Concepção de Professor}

\begin{tabular}{|c|l|}
\hline & $4,6,7,8,9,10,11,12,15,16,17,18,21,26,32,34,35,40,41,45$, \\
& $47,49,54,55,56,57,61,63,64,65,66,67,68,72,76,77,78,79$, \\
& $80,81,82,83,84,85,86,87,89,90,91,92,96,98,101,104,105$, \\
& $106,107,108,110,112,116,117,119,122,127,128,129,131$, \\
& $133,143,144,145,146,151,152,153,155,157,167,168,169$, \\
& 170 \\
\hline Não Menciona & $5,13,14,20,23,24,28,29,31,37,39,42,46,50,52,53,58,59$, \\
& $62,70,71,73,75,94,100,102,103,118,124,130,132,136$, \\
& $140,141,142,147,148,154,156,160,1614,165,166,171$ \\
\hline \multirow{2}{*}{ Saberes da Prática } & $2,23,27,33,36,39,43,44,51,60,75,88,99,100,102,109,111$, \\
& $117,121,134,140,142,164,166$ \\
\hline \multirow{2}{*}{ Critico } & $1,3,19,22,25,30,38,48,69,74,93,95,97,102,113,114,115$, \\
& $120,121,123,125,126,132,135,137,138,139,140,149,150$, \\
\hline & $156,159,161,162,163,164$ \\
\hline
\end{tabular}

